\title{
Scoping Analysis of Source Term and Functional Containment Attenuation Factors
}

February 2012
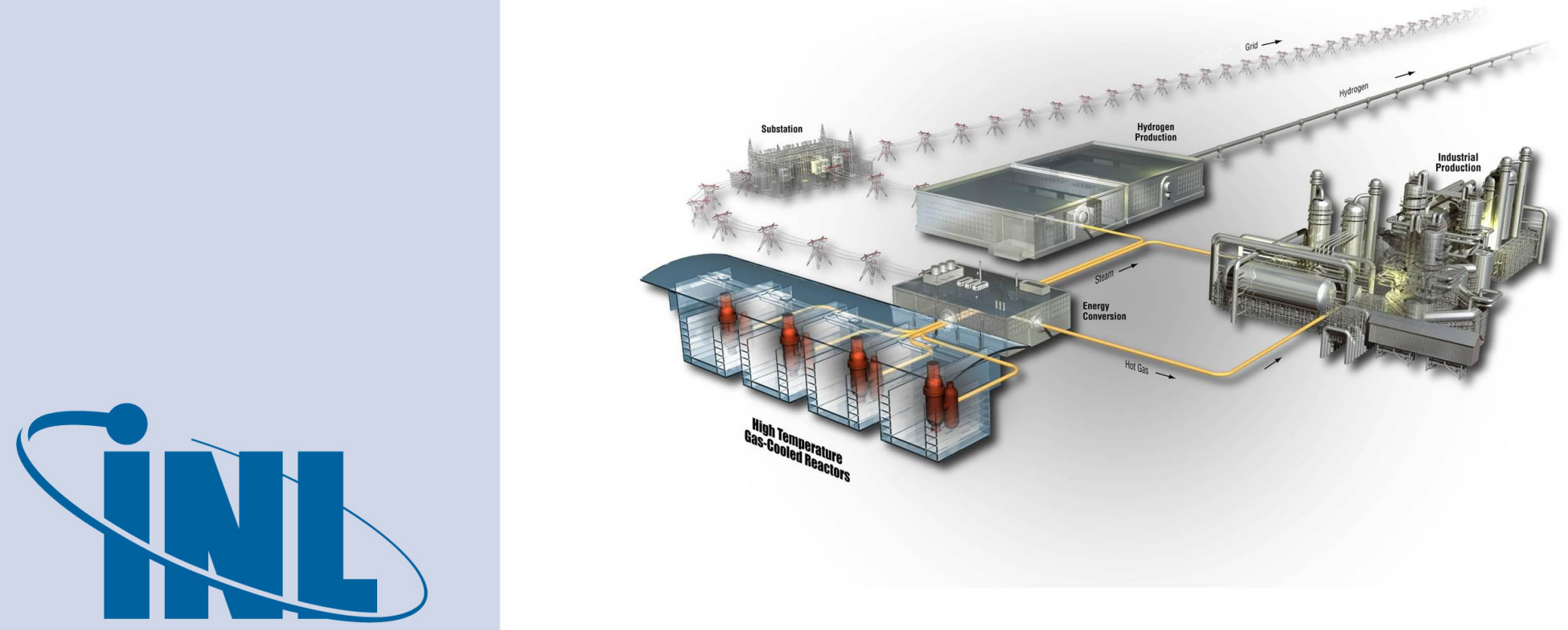

Idaho National Laboratory 


\section{DISCLAIMER}

This information was prepared as an account of work sponsored by an agency of the U.S. Government. Neither the U.S. Government nor any agency thereof, nor any of their employees, makes any warranty, expressed or implied, or assumes any legal liability or responsibility for the accuracy, completeness, or usefulness, of any information, apparatus, product, or process disclosed, or represents that its use would not infringe privately owned rights. References herein to any specific commercial product, process, or service by trade name, trade mark, manufacturer, or otherwise, does not necessarily constitute or imply its endorsement, recommendation, or favoring by the U.S. Government or any agency thereof. The views and opinions of authors expressed herein do not necessarily state or reflect those of the U.S. Government or any agency thereof. 
INL/EXT-11-24034

Revision 1

\section{Scoping Analysis of Source Term and Functional Containment Attenuation Factors}

February 2012

Idaho National Laboratory

Next Generation Nuclear Plant Project

Idaho Falls, Idaho 83415

http://www.inl.gov

Prepared for the

U.S. Department of Energy

Office of Nuclear Energy

Under DOE Idaho Operations Office

Contract DE-AC07-05ID14517 

Scoping Analysis of Source Term and Functional Containment Attenuation Factors

INLIEXT-11-24034

Revision 1

February 2012

Approved by:
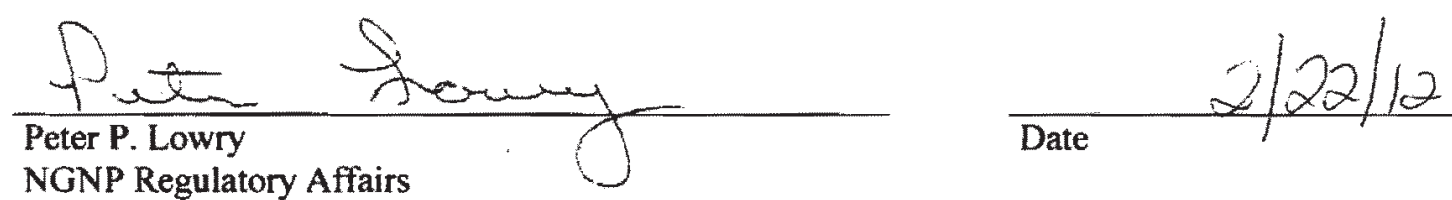

NGNP Regulatory Affairs

Date

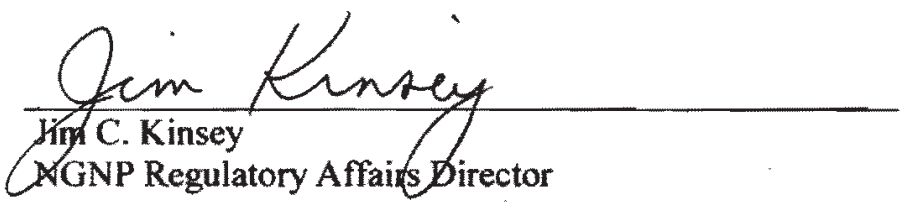

$2 \cdot 22-12$

AGNP Regulatory Affairs Director

Date

and Poss.

David A. Patti

$2-23-12$

VHTR R\&D Director

Date 



\section{EXECUTIVE SUMMARY}

This scoping analysis estimates postulated radiological releases and associated offsite doses from representative high temperature gas-cooled reactor (HTGR) module designs. The objectives of this analysis were to: (1) provide insight for next generation nuclear plant (NGNP) Technology Development Program activities, (2) provide a preliminary assessment of the performance of the HTGR relative to NGNP Project objectives regarding public health and safety; and (3) support ongoing NGNP Project discussions regarding possible HTGR deployment in advance of completion of detailed design and accident analyses.

It is important to note that the results of these analyses are not intended for, nor suitable for, submittal to regulatory authorities as part of the licensing basis of the HTGR. The analyses are intended solely to provide insights and internal guidance for the NGNP Project.

In the absence of complete technical information to support detailed mechanistic source term assessments, the NGNP Project utilized a simplified model to perform parametric scoping analyses of the release and retention parameters that define the source terms for a modular HTGR. To estimate the source terms, the model incorporates expert opinion regarding the performance of each of the radionuclide barriers that comprise the HTGR functional containment: (1) the fuel particle kernel, (2) the fuel particle coatings, (3) the fuel matrix and graphite, (4) the helium pressure boundary; and (5) the reactor building. These assessments reflect improved fuel performance characteristics being demonstrated by the Advanced Gas Reactor (AGR) Fuel Development and Qualification Program.

Accident scenarios were chosen for analysis based on the results of previous modular HTGR safety analyses. Analyses were limited to the scenarios that have been shown to present the highest risk to public health and safety. The results of the analyses were compared to the following project objectives regarding the protection of public health and safety:

- Protection of the health and safety of the public and the environment with the objective that under no postulated accident condition would public evacuation or sheltering be required. To achieve this objective, the NGNP must meet:

- The Nuclear Regulatory Commission (NRC) siting criteria for both the plant exclusion area boundary (EAB) and low population zone (LPZ) (10CFR52.47/50.34) at a nominal distance of $400 \mathrm{~m}$ from the reactor centerline.

- The early phase Environmental Protection Agency (EPA) plume exposure Protective Action Guides (PAGs) at the plant EAB.

- Protection of the food and water supplies from being unacceptably impacted by radionuclide contamination. This objective is satisfied by either meeting the intermediate phase EPA ingestion pathway PAGs at the plant EAB, or by assuring through the specific siting analyses and related administrative controls that no food or water supplies exist in the area immediately surrounding the EAB.

- The analyses were completed for a single reactor module. Additional analyses will be needed to confirm that project objectives are satisfied for multi-module HTGR facilities when responding to postulated events that may result in fission product release from more than one module.

In assessing the results against the NRC siting criteria, the model utilized conservative assumptions regarding the performance of the radionuclide release barriers and did not credit any fission product release attenuation by the reactor building. With these assumptions, the model shows that the siting criteria are met at the EAB with large margins for all single-module reactor configurations and accident scenarios assessed, as discussed in Section 5.1. 
In assessing the results against the EPA plume exposure PAGs, the model utilized realistic (mean) assumptions on the performance of all of the radionuclide barriers, including the reactor building. The model results show that the PAGs are met at the EAB with large margins for all single-module reactor configurations and accident scenarios assessed, as discussed in Section 0.

In assessing the potential for contamination of food and water supplies, the model utilized realistic (mean) assumptions on the performance of all of the radionuclide barriers, including the reactor building, and modeling of the ingestion of foods consistent with regulatory guidance. The model results indicate that the ingestion limits for an infant receptor (the most limiting case) are generally exceeded at the $400 \mathrm{~m}$ $\mathrm{EAB}$ but are met at approximately $900 \mathrm{~m}$ for all single-module reactor configurations and accident scenarios assessed.

The results presented in this report indicate that I-131 is the dominant contributor to thyroid doses as has been observed in past modular HTGR safety analyses. However, the dominant contributors to total effective doses (includes all health effects such as thyroid and whole body weighted by their relative health contribution) for the offsite receptors for the accident scenarios assessed are Ag-111, Ag-110m, and Ce-144. This result is different from results of previous modular HTGR accident analyses in which Cs-137 was the dominant contributor for the offsite total effective dose. Because of the better fuel performance assumed in this study based on recent encouraging results of fuel R\&D, defect levels and assumed incremental failure rates under normal and accident conditions are lower than used in past modular HTGR accident analyses. This better fuel performance translates into much lower release of Cs137. Thus, these silver and cerium isotopes that were minor contributors in the past are more important now. This result may also be due in part to the simplified methodology used in this scoping study to establish the source term. Enhanced attention to the behavior of these isotopes will be given in the NGNP Technology Development Program going forward.

In summary, the results of this scoping analysis indicate that the NGNP Project objectives related to offsite dose for the inhalation pathway are expected to be met for a single reactor module with the functional containment performance levels that are currently envisioned and being validated, in part through the NGNP Technology Development Program. Additional technical assessment and design development work may be required to fully achieve project objectives related to the ingestion pathway PAG. 


\section{CONTENTS}

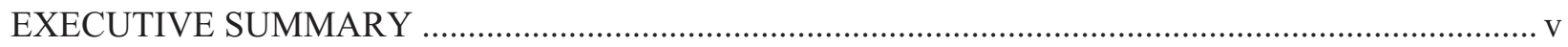

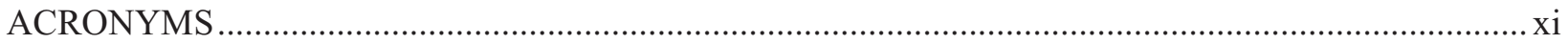

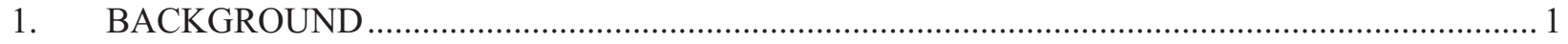

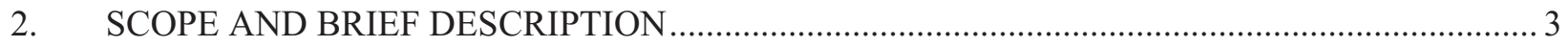

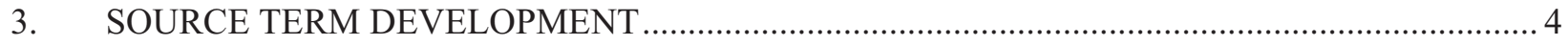

3.1 HTGR Configurations, Fission Product Classes and Associated Inventories........................ 4

3.2 Tristructural-isotropic (TRISO) Fuel Fabrication Quality ................................................. 6

3.3 Fission Product Release from Fuel/Graphite during Normal Operation................................ 6

3.4 Attenuation Factors during Normal Operations ................................................................ 7

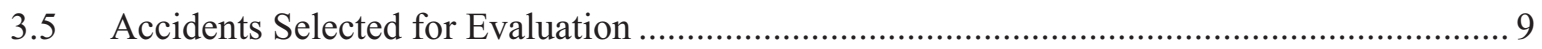

3.6 Releases and Attenuation Factors Under Accident Conditions ......................................... 10

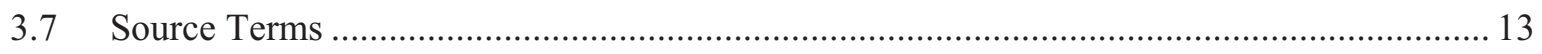

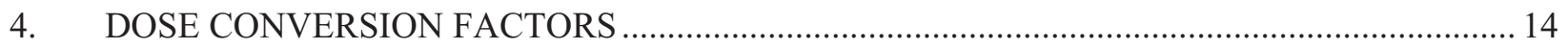

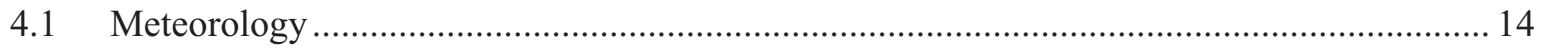

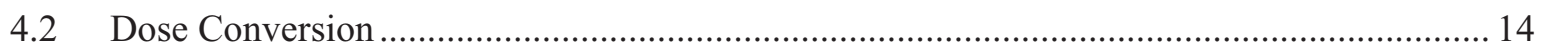

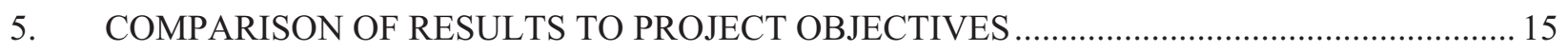

5.1 Comparison with NRC Siting Criteria (Cases A and B) ................................................ 15

5.2 Comparison with PAG Emergency Planning Criteria (Cases C-F).................................... 16

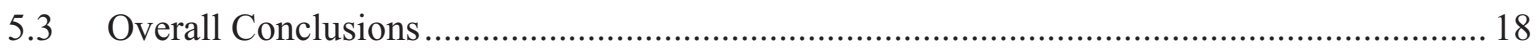

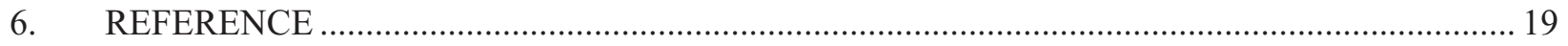

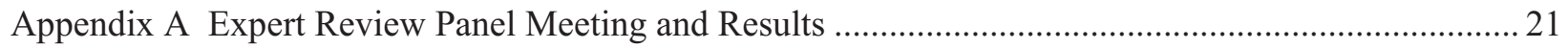

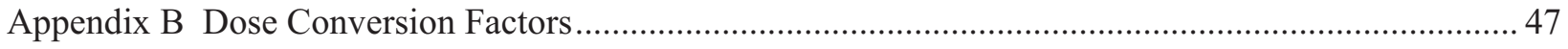

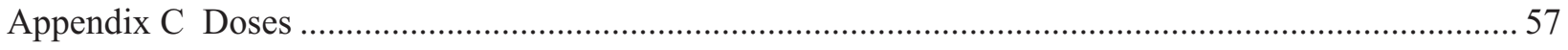

Appendix D Key Limitations and Assumptions Used in the Scoping Analyses .................................. 89

\section{FIGURES}

Figure 1. Case E, infant, EDE (rem), single reactor module. ........................................................... 17

Figure 2. Case F, infant, thyroid (rem) single reactor module.......................................................... 18 


\section{TABLES}

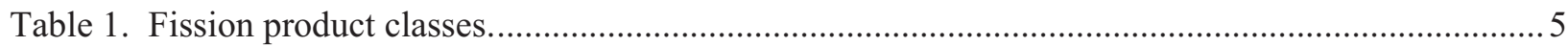

Table 2. Initial core fission product inventories, in curies...................................................................... 5

Table 3. Fuel defect fractions for all reactor configurations.................................................................... 6

Table 4. Prismatic $700^{\circ} \mathrm{C}$ ROT incremental fuel failure fractions under normal operations..................... 7

Table 5. Prismatic $700^{\circ} \mathrm{C}$ ROT barrier attenuation factors during normal operations.............................. 8

Table 6. Mean values for I-131, Cs-137, and Sr-90 inventories (curies) released to the helium pressure boundary and retained in the fuel matrix and graphite................................................ 9

Table 7. Mechanistic source term events for model simulations.......................................................... 10

Table 8. Prismatic $700^{\circ} \mathrm{C}$ ROT short-term accident attenuation factors for a break in $\mathrm{He}$ pressure boundary.

Table 9. Prismatic $700^{\circ} \mathrm{C}$ ROT long-term accident release and attenuation factors for a break in

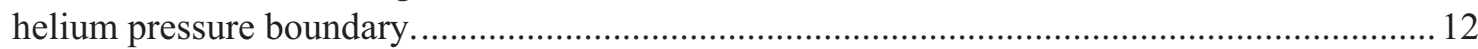

Table 10. $600 \mathrm{MW}(\mathrm{t})$ Prismatic $700^{\circ} \mathrm{C}$ ROT, source terms for a break in He pressure boundary............. 13

Table 11. Dose limits and associated protocols for calculating exposures............................................ 14

Table 12. Upper bound comparison with NRC siting criteria (DBA) - (TEDE rem). .......................... 15

Table 13. Realistic comparison with plume exposure PAG at EAB ...................................................... 16

Table A-1. $600 \mathrm{MW}(\mathrm{t})$ prismatic $700^{\circ} \mathrm{C}$ ROT-normal operations_-release fractions and

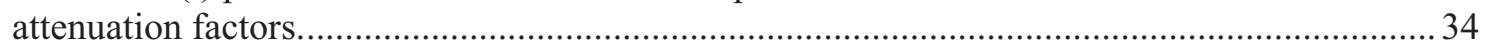

Table A-2. $600 \mathrm{MW}(\mathrm{t})$ prismatic $700^{\circ} \mathrm{C}$ ROT_ break in HPB — short term attenuation factors..............35

Table A-3. $600 \mathrm{MW}(\mathrm{t})$ prismatic $700^{\circ} \mathrm{C}$ ROT_ break in HPB - long term release fractions and

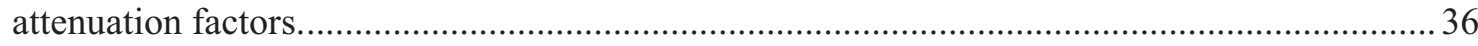

Table A-4. $600 \mathrm{MW}(\mathrm{t})$ prismatic $700^{\circ} \mathrm{C}$ ROT-water ingress — short term attenuation factors.............. 37

Table A-5. $600 \mathrm{MW}(\mathrm{t})$ prismatic $700^{\circ} \mathrm{C}$ ROT — water ingress - long term release fractions and

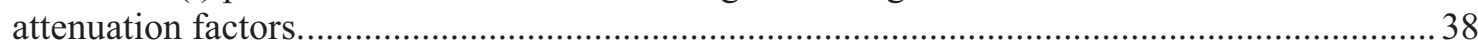

Table A-6. $600 \mathrm{MW}(\mathrm{t})$ prismatic $900^{\circ} \mathrm{C}$ ROT—normal operations - release fractions and

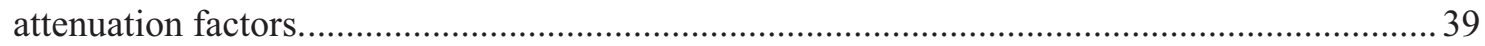

Table A-7. $600 \mathrm{MW}(\mathrm{t})$ prismatic $900^{\circ} \mathrm{C}$ ROT— break in HPB—short term attenuation factors............. 40

Table A-8. $600 \mathrm{MW}(\mathrm{t})$ prismatic $900^{\circ} \mathrm{C}$ ROT - break in $\mathrm{HPB}$ - long term release fractions and attenuation factors.

Table A-9. $250 \mathrm{MW}(\mathrm{t})$ pebble bed $700^{\circ} \mathrm{C}$ ROT_normal operations-release fractions and attenuation factors.

Table A-10. $250 \mathrm{MW}(\mathrm{t})$ pebble bed $700^{\circ} \mathrm{C}$ ROT_-break in HPB — short term attenuation factors......... 43

Table A-11. 250 MW(t) pebble bed $700^{\circ} \mathrm{C}$ ROT— break in HPB - long term release fractions

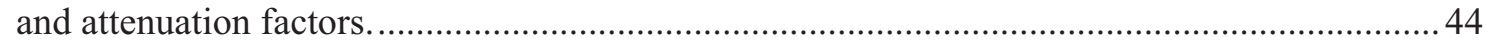

Table A-12. $250 \mathrm{MW}(\mathrm{t})$ pebble bed $700^{\circ} \mathrm{C}$ ROT — water ingress — short term attenuation factors.......... 45

Table A-13. $250 \mathrm{MW}(\mathrm{t})$ pebble bed $700^{\circ} \mathrm{C}$ ROT — water ingress-long term release fractions and attenuation factors. 
Table B-1. Dose conversion factors —Cases A/B 400 meters (rem/curie). ............................................. 49

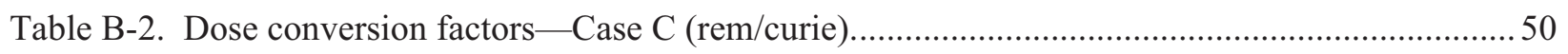

Table B-3. Dose conversion factors - Case D (rem/curie). ............................................................... 50

Table B-4. Dose conversion factors - Case E, infant, whole body (rem/curie) .....................................51

Table B-5. Dose conversion factors - Case E, adult, whole body (rem/curie). .....................................52

Table B-6. Dose conversion factors — Case F, infant, thyroid (rem/curie) . ........................................... 53

Table B-7. Dose conversion factors - Case F, adult, thyroid (rem/curie) ................................................ 54

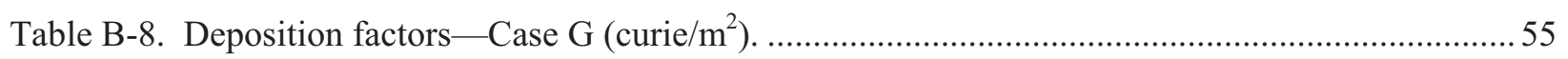

Table C-1. $600 \mathrm{MW}(\mathrm{t})$ prismatic $700^{\circ} \mathrm{C}$ ROT— break in HPB — source term (curies)...........................59

Table C-2. $600 \mathrm{MW}(\mathrm{t})$ prismatic $700^{\circ} \mathrm{C}$ ROT_-break in HPB — Cases A and B-400 $\mathrm{m}$ from release (rem).

Table C-3. $600 \mathrm{MW}(\mathrm{t})$ prismatic $700^{\circ} \mathrm{C}$ ROT_-break in $\mathrm{HPB}$ - Cases C and D- $400 \mathrm{~m}$ from release (rem).

Table C-4. $600 \mathrm{MW}(\mathrm{t})$ prismatic $700^{\circ} \mathrm{C}$ ROT — break in HPB — Cases E and F, infant and adult$400 \mathrm{~m}$ from release (rem).

Table C-5. $600 \mathrm{MW}(\mathrm{t})$ prismatic $700^{\circ} \mathrm{C}$ ROT_-break in HPB — Cases E and F, infant and adult$800 \mathrm{~m}$ from release (rem)

Table C-6. $600 \mathrm{MW}(\mathrm{t})$ prismatic $700^{\circ} \mathrm{C}$ ROT_-break in HPB — Cases E and F, infant and adult $1600 \mathrm{~m}$ from release (rem).

Table C-7. $600 \mathrm{MW}(\mathrm{t})$ prismatic $700^{\circ} \mathrm{C}$ ROT—water ingress - source term (curies).

Table C-8. $600 \mathrm{MW}(\mathrm{t})$ prismatic $700^{\circ} \mathrm{C}$ ROT — water ingress - Cases A and B- $400 \mathrm{~m}$ from release (rem).

Table C-9. $600 \mathrm{MW}(\mathrm{t})$ prismatic $700^{\circ} \mathrm{C}$ ROT — water ingress - Cases C and D- $400 \mathrm{~m}$ from release (rem).

Table C-10. $600 \mathrm{MW}(\mathrm{t})$ prismatic $700^{\circ} \mathrm{C}$ ROT — water ingress - Cases E and F, infant and adult $-400 \mathrm{~m}$ from release (rem).

Table C-11. $600 \mathrm{MW}(\mathrm{t})$ prismatic $700^{\circ} \mathrm{C}$ ROT-water ingress-Cases E and F, infant and adult $-800 \mathrm{~m}$ from release (rem).

Table C-12. $600 \mathrm{MW}(\mathrm{t})$ prismatic $700^{\circ} \mathrm{C}$ ROT - water ingress - Cases E and F, infant and

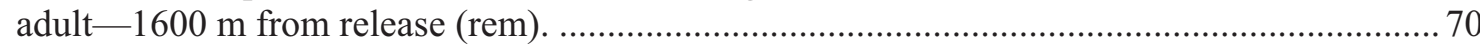

Table C-13. $600 \mathrm{MW}(\mathrm{t})$ prismatic $900^{\circ} \mathrm{C}$ ROT — break in HPB — source term (curies).........................71

Table C-14. $600 \mathrm{MW}(\mathrm{t})$ prismatic $900^{\circ} \mathrm{C}$ ROT_-break in HPB — Cases A and B- $400 \mathrm{~m}$ from release (rem).

Table C-15. $600 \mathrm{MW}(\mathrm{t})$ prismatic $900^{\circ} \mathrm{C}$ ROT — break in HPB — Cases C and D- $400 \mathrm{~m}$ from release (rem). .73

Table C-16. $600 \mathrm{MW}(\mathrm{t})$ prismatic $900^{\circ} \mathrm{C}$ ROT_-break in HPB — Cases E and F, infant and adult $-400 \mathrm{~m}$ from release (rem). .74

Table C-17. $600 \mathrm{MW}(\mathrm{t})$ prismatic $900^{\circ} \mathrm{C}$ ROT_-break in HPB — Cases E and F, infant and adult $-800 \mathrm{~m}$ from release (rem). 
Table C-18. $600 \mathrm{MW}(\mathrm{t})$ prismatic $900^{\circ} \mathrm{C}$ ROT — break in HPB — Cases E and F, infant and adult- $1600 \mathrm{~m}$ from release (rem).

Table C-19. $250 \mathrm{MW}(\mathrm{t})$ pebble bed $700^{\circ} \mathrm{C}$ ROT_-break in HPB—source term (curies).

Table C-20. $250 \mathrm{MW}(\mathrm{t})$ pebble bed $700^{\circ} \mathrm{C}$ ROT_-break in HPB — Cases A and B- $400 \mathrm{~m}$ from release (rem).

Table C-21. $250 \mathrm{MW}(\mathrm{t})$ pebble bed $700^{\circ} \mathrm{C}$ ROT_-break in HPB — Cases C and D- $400 \mathrm{~m}$ from release (rem).

Table C-22. $250 \mathrm{MW}(\mathrm{t})$ pebble bed $700^{\circ} \mathrm{C}$ ROT - break in HPB — Cases E and F, infant and adult $-400 \mathrm{~m}$ from release (rem).

Table C-23. $250 \mathrm{MW}(\mathrm{t})$ pebble bed $700^{\circ} \mathrm{C}$ ROT_-break in HPB — Cases E and F, infant and adult $-800 \mathrm{~m}$ from release (rem).

Table C-24. $250 \mathrm{MW}(\mathrm{t})$ pebble bed $700^{\circ} \mathrm{C}$ ROT_-break in HPB — Cases E and F, infant and adult $-1600 \mathrm{~m}$ from release (rem).

Table C-25. $250 \mathrm{MW}(\mathrm{t})$ pebble bed $700^{\circ} \mathrm{C}$ ROT — water ingress - source term (curies).

Table C-26. $250 \mathrm{MW}(\mathrm{t})$ pebble bed $700^{\circ} \mathrm{C}$ ROT - water ingress - Cases A and B- $400 \mathrm{~m}$ from release (rem).

Table C-27. $250 \mathrm{MW}(\mathrm{t})$ pebble bed $700^{\circ} \mathrm{C}$ ROT-water ingress - Cases C and D-400 $\mathrm{m}$ from release (rem).

Table C-28. $250 \mathrm{MW}(\mathrm{t})$ Pebble Bed $700^{\circ} \mathrm{C}$ ROT — water ingress - Cases E and F, infant and adult $-400 \mathrm{~m}$ from release (rem).

Table C-29. $250 \mathrm{MW}(\mathrm{t})$ pebble bed $700^{\circ} \mathrm{C}$ ROT-water ingress - Cases E and F, infant and adult $-800 \mathrm{~m}$ from release (rem).

Table C-30. $250 \mathrm{MW}(\mathrm{t})$ pebble bed $700^{\circ} \mathrm{C} \mathrm{ROT}$ - water ingress - Cases E and F, infant and adult $-1600 \mathrm{~m}$ from release (rem). 


\section{ACRONYMS}

$\mathrm{AF} \quad$ attenuation factors

AGR Advanced Gas Reactor

$\mathrm{D} / \mathrm{Q} \quad$ deposition

DBA design basis accidents

EAB exclusion area boundary

EPA Environmental Protection Agency

HPB helium pressure boundary

HTGR high temperature gas-cooled reactor

LBE licensing basis events

LPZ low population zone

MACCS2 MELCOR Accident Consequence Code System

MHTGR modular high temperature gas-cooled reactor

MST Mechanistic Source Terms

NGNP Next Generation Nuclear Plant

NRC Nuclear Regulatory Commission

PAG Protective Action Guides

R\&D research and development

PBMR Pebble Bed Modular Reactor

$\mathrm{RB} \quad$ reactor building

RCCS reactivity cavity cooling system

ROT reactor outlet temperature

SSC safety-related systems, structures, and components

TRISO tristructural-isotropic

$\chi / \mathrm{Q} \quad$ atmospheric dispersion 


\section{Scoping Analysis of Source Term and Functional Containment Attenuation Factors}

\section{BACKGROUND}

This scoping analysis estimates postulated radiological releases and associated offsite doses from representative high temperature gas-cooled reactor (HTGR) module designs. The objectives of this analysis were to: (1) provide insight for next generation nuclear plant (NGNP) Technology Development Program activities, (2) provide a preliminary assessment of the performance of the HTGR relative to NGNP Project objectives regarding public health and safety; and (3) support ongoing NGNP Project discussions regarding possible HTGR deployment in advance of completion of detailed design and accident analyses.

Because the design of the NGNP demonstration plant has not progressed to the point where definitive source term analyses could be performed, the calculation of source terms used in these analysis is simplified and is not considered final. In the interim, however, to provide an approximate characterization of the source term, the NGNP Project developed a simplified parametric model to establish mechanistic source term estimates for a set of representative HTGR configurations based on prior detailed analyses of similar modular HTGRs. ${ }^{1}$

This report summarizes the results of evaluating the specified radionuclide barrier performance characteristics (i.e., attenuation factors) of the functional containment, focusing on improved fuel performance, to determine the mechanistic source term and the offsite dose consequences for a set of HTGR configurations using a simplified model. To provide an approximate characterization of the source term, the NGNP Project model incorporates expert opinion related to the performance of each of the radionuclide barriers that comprise the HTGR functional containment: (1) the fuel particle kernel; (2) the fuel particle coatings, (3) the fuel matrix and graphite, (4) the helium pressure boundary; and (5) the reactor building, as discussed in HTGR Mechanistic Source Terms White Paper (MST white paper); INL/EXT-10-17997. ${ }^{2}$ As more testing is completed under the NGNP Technology Development Program and further design development is completed, the assumed values for the barrier performance allocations can be revised, as necessary. In addition to establishing estimates of the source terms, the model was designed to interface with the MELCOR Accident Consequence Code System (MACCS2) code ${ }^{3}$ to derive dose estimates from the source term.

The resulting estimates were then compared to project objectives regarding the protection of public health and safety. The key principles of the NGNP Project public safety objectives include:

- Protection of the health and safety of the public and the environment with the objective that under no postulated accident condition would public evacuation or sheltering be required. To achieve this objective, the NGNP must meet:

- The Nuclear Regulatory Commission (NRC) siting criteria for both the plant exclusion area boundary (EAB) and low population zone (LPZ) (10 CFR 52.47/50.34) at a nominal distance of $400 \mathrm{~m}$ from the reactor centerline

- $\quad$ The early phase EPA plume exposure Protective Action Guides (PAGs) at the plant EAB. 
- Protection of the food and water supplies from being unacceptably impacted by radionuclide contamination. This objective is satisfied by either meeting the intermediate phase EPA ingestion pathway PAGs at the plant EAB, or by assuring through the specific siting analyses and related administrative controls that no food or water supplies exist in the area immediately surrounding the EAB.

This report describes the model, documents key assumptions used, and presents the results of several simulations involving a set of proposed reactor configurations and accident scenarios involving a single HTGR module.

It is important to note that the results of these analyses are not intended for, nor suitable for, submittal to regulatory authorities as part of the licensing basis of the HTGR. The analyses are intended solely to provide insights for the NGNP Technology Development Program activities and internal guidance for the NGNP Project. 


\section{SCOPE AND BRIEF DESCRIPTION}

The HTGR Mechanistic Source Terms White Paper provides a description of the approach the NGNP Project is taking in developing radiological source terms for licensing basis events (LBEs). Consistent with the HTGR safety design approach, this approach establishes the technical basis for taking appropriate credit for the radionuclide retention capabilities of each of the functional containment's multiple barriers to radionuclide transport to the environment. This mechanistic approach is expected to be used by future HTGR designers and licensing applicants for the following evaluations:

- Demonstration of compliance with 10 CFR 52.47/50.34 offsite dose requirements for design basis accidents (DBA), with only safety-related systems, structures, and components (SSCs) considered.

- Demonstration of compliance with PAGs for LBEs, with all SSCs (safety and non-safety) considered.

The mechanistic source terms will ultimately be determined using computer codes and models developed by the reactor vendor team to calculate the response of the reactor and associated barriers under normal and off-normal conditions as part of the safety assessment of the HTGR. In the absence of complete technical information to support detailed mechanistic source term assessments, the NGNP Project utilized a simplified model to perform parametric scoping analyses of the release and retention parameters that define the source terms for a modular HTGR.

The model requires the user to select a reactor configuration, reactor core size (thermal power rating), reactor outlet temperature, fuel degradation and failure fractions, and attenuation factors associated with each of the radionuclide barriers that make up the functional containment. The model uses Monte Carlo simulation to address uncertainties in fuel and barrier performance and provides range estimates of curies released for a user-specified accident scenario. The model combines the results of this probabilistic estimate with dose conversion coefficients calculated at specified distances from the reactor building ${ }^{4}$ to provide an estimate of the dose (rem) to a receptor.

The dose is evaluated for each design and accident as summarized below.

- The distribution of the source term, defined as the radionuclides released from the reactor building to the environment, is determined as a function of the initial core inventory and a release coefficient. The release coefficient is developed by combining the nuclide dependent distributions associated with the release of radionuclides and the attenuation factors associated with the barriers mitigating the release. The source term is calculated based upon fission products released from the fuel during both normal operations and accidents (see Section 3).

- Atmospheric dispersion $(\chi / \mathrm{Q})$ and deposition $(\mathrm{D} / \mathrm{Q})$ values are determined using the methodology and meteorological information identified in the report, "Engineering Evaluation of $\chi / \mathrm{Q}$ Values Consistent with Regulatory Guide 1.145." For the purpose of the dose calculation, distances of $400 \mathrm{~m}, 800 \mathrm{~m}$, $1600 \mathrm{~m}, 3200 \mathrm{~m}$, and $8000 \mathrm{~m}$ are specified (see Section 4.1).

- The nuclide dependent distribution of the dose conversion factors is then adjusted by applicable $\chi / \mathrm{Q}$ or $\mathrm{D} / \mathrm{Q}$ values to derive a distance-weighted dose conversion factor, defined as the dose to an individual at a specified distance per curie of material released. The distance-weighted dose conversion factors are calculated externally to the model in MACCS (see Section 4.2).

- The results of the probabilistically derived source term and the distance-weighted dose conversion and deposition factors for each nuclide are then combined and summed as shown in the equation below. The results of this are then compared against the NGNP Project selected set of acceptance criteria (see Section 0).

Dose $_{i}=$ Core Inventory $_{i}($ curies $) \times$ Release Coefficient $_{i}($ fraction $) \times$ Dose Conversion Factor $_{i}\left(\right.$ rem $_{\text {(curie })}$ 


\section{SOURCE TERM DEVELOPMENT}

An expert panel of personnel knowledgeable of NGNP fuel development activities, HTGR technology development activities, past HTGR accident analysis, representative design alternatives and the NGNP licensing approach for mechanistic source terms was convened during the week of September 5, 2011. Identification of the expert panel and summary of the meeting is contained in Appendix A to this report. This expert panel established the attributes and accident scenarios that were considered for determining the mechanistic source terms within the dose evaluation model.

Consistent with the approach discussed in the MST white paper, the radionuclide source terms were derived as a function of the performance of each of the barriers to radionuclide transport under eventspecific conditions. Barrier performance was estimated based on expert opinion. Radionuclide retention of the barriers associated with fuel and graphite was estimated based on current capabilities of the technology as recently demonstrated in the Advanced Gas Reactor (AGR) fuel program. In assessing against the NRC siting criteria, the analyses utilized conservative estimates regarding the performance of the radionuclide release barriers, and did not credit any fission product release attenuation by the reactor building. In assessing against the EPA plume exposure PAGs, the analyses utilized realistic (mean) estimates of the performance of the radionuclide barriers including the reactor building.

The panel examined each design configuration, each event, and each radionuclide source by estimating a 50\% and 95\% upper bound value attenuation factor with an uncertainty distribution for each barrier. The radionuclide release distributions for each event for each source from each barrier were combined statistically to calculate the source terms released from the reactor building. These source terms were then evaluated in accordance with the accident rule sets appropriate to the NRC and EPA requirements as discussed in Section 4 and Table 11.

\subsection{HTGR Configurations, Fission Product Classes and Associated Inventories}

During this meeting, a number of HTGR configurations were considered to reflect the needs for various potential missions for a HTGR. Based on pre-conceptual and conceptual designs established during the NGNP Project, both prismatic and pebble fuel modular HTGRs with a range of reactor power ratings and reactor coolant outlet temperatures (ROT) were addressed. The configurations carried forth for further evaluation were judged representative of the above considerations and included:

a. A single $600 \mathrm{MW}(\mathrm{t})$ prismatic $\mathrm{HTGR}$ module with a $700^{\circ} \mathrm{C} \mathrm{ROT}$, providing high temperature steam via a steam generator.

b. A single $600 \mathrm{MW}(\mathrm{t}) 900^{\circ} \mathrm{C}$ ROT prismatic HTGR module providing high temperature process heat via an intermediate heat exchanger.

c. A single $250 \mathrm{MW}(\mathrm{t}) 700^{\circ} \mathrm{C}$ ROT pebble bed HTGR module providing high temperature steam via a steam generator.

To facilitate the development of radionuclide-specific source terms, the team developed a set of fission product classes, listed in Table 1. Radionuclides within a fission product class are assumed to have the same release and attenuation factors based on physical and chemical properties, with the exception of silver where the two representative isotopes have much different half-lives. The short-lived $\mathrm{Ag}-111$ is distinguished from the much longer-lived Ag-110m in estimating the diffusive release from the fuel under normal operation. Each fission product class contains the key radionuclides, identified via past modular HTGR analyses that are expected to account for the majority of the offsite dose. 
Table 1. Fission product classes.

\begin{tabular}{|l|l|}
\hline Fission Product Class & Characteristic Nuclides \\
\hline Noble Gases & Kr-85, Kr-88, Xe-133 \\
\hline $\mathrm{I}, \mathrm{Br}, \mathrm{Te}, \mathrm{Se}$ & $\mathrm{I}-131, \mathrm{I}-133, \mathrm{Te}-132$ \\
\hline $\mathrm{Cs}, \mathrm{Rb}$ & $\mathrm{Cs}-134, \mathrm{Cs}-137$ \\
\hline $\mathrm{Sr}, \mathrm{Ba}, \mathrm{Eu}$ & $\mathrm{Sr}-90$ \\
\hline $\mathrm{Ag}, \mathrm{Pd}$ & $\mathrm{Ag}-110 \mathrm{~m}, \mathrm{Ag}-111$ \\
\hline $\mathrm{Sb}$ & $\mathrm{Sb}-125$ \\
\hline $\mathrm{Mo}, \mathrm{Ru}, \mathrm{Rh}, \mathrm{Tc}$ & $\mathrm{Ru}-103$ \\
\hline $\mathrm{La}, \mathrm{Ce}$ & $\mathrm{La}-140, \mathrm{Ce}-144$ \\
\hline $\mathrm{Pu}$, actinides & $\mathrm{Pu}-239$ \\
\hline
\end{tabular}

Individual radionuclide inventories used in the evaluation were based on the core for the $600 \mathrm{MW}(\mathrm{t})$ prismatic configuration. ${ }^{6}$ Radionuclide inventories for the $250 \mathrm{MW}(\mathrm{t})$ pebble bed configuration were scaled based on that inventory. Inventories for the $600 \mathrm{MW}(\mathrm{t})$ prismatic and $250 \mathrm{MW}(\mathrm{t})$ pebble bed are shown in Table 2. With regard to scaling of the $600 \mathrm{MW}(\mathrm{t})$ prismatic HTGR radionuclide inventories to obtain the inventories for the $250 \mathrm{MW}(\mathrm{t})$ pebble bed configuration, it is recognized that the scaling approach is an approximation that does not take into account the detailed differences between the pebble and prismatic fuel configurations and the detailed differences between the operating conditions of the two reactors. However, it is believed that the approximation is acceptable for the purposes of these analyses.

Table 2. Initial core fission product inventories, in curies.

\begin{tabular}{|c|c|c|c|}
\hline \multirow{3}{*}{ Fission Product Class } & $\begin{array}{c}\text { Characteristic } \\
\text { Nuclide }\end{array}$ & $\begin{array}{c}\text { Inventory - } \\
600 \mathrm{MW}(\mathrm{t}) \\
\text { Prismatic }\end{array}$ & $\begin{array}{c}\text { Inventory - } \\
250 \mathrm{MW}(\mathrm{t}) \\
\text { Pebble Bed }\end{array}$ \\
\hline \multirow{3}{*}{ Noble Gases } & $\mathrm{Xe}-133$ & $3.63 \mathrm{E}+07$ & $1.51 \mathrm{E}+07$ \\
\cline { 2 - 4 } & $\mathrm{Kr}-85$ & $1.90 \mathrm{E}+05$ & $7.92 \mathrm{E}+04$ \\
\cline { 2 - 4 } & $\mathrm{Kr}-88$ & $1.85 \mathrm{E}+07$ & $7.71 \mathrm{E}+06$ \\
\hline \multirow{3}{*}{$\mathrm{I}, \mathrm{Br}, \mathrm{Te}, \mathrm{Se}$} & $\mathrm{I}-131$ & $2.00 \mathrm{E}+07$ & $8.33 \mathrm{E}+06$ \\
\cline { 2 - 4 } & $\mathrm{I}-133$ & $3.60 \mathrm{E}+07$ & $1.50 \mathrm{E}+07$ \\
\hline \multirow{2}{*}{$\mathrm{Cs}, \mathrm{Rb}$} & $\mathrm{Cs}-132$ & $2.71 \mathrm{E}+07$ & $1.13 \mathrm{E}+07$ \\
\hline \multirow{2}{*}{$\mathrm{Sr}, \mathrm{Ba}, \mathrm{Eu}$} & $\mathrm{Cs}-134$ & $1.69 \mathrm{E}+06$ & $7.04 \mathrm{E}+05$ \\
\hline \multirow{2}{*}{$\mathrm{Ag}, \mathrm{Pd}$} & $\mathrm{Sr}-90$ & $1.90 \mathrm{E}+06$ & $7.92 \mathrm{E}+05$ \\
\hline $\mathrm{Sb}$ & $\mathrm{Ag}-110 \mathrm{~m}$ & $2.81 \mathrm{E}+04$ & $7.04 \mathrm{E}+05$ \\
\hline & $\mathrm{Ag}-111$ & $2.96 \mathrm{E}+06$ & $1.17 \mathrm{E}+04$ \\
\hline $\mathrm{Mo}, \mathrm{Ru}, \mathrm{Rh}, \mathrm{Tc}$ & $\mathrm{Sb}-125$ & $2.35 \mathrm{E}+05$ & $9.79 \mathrm{E}+04$ \\
\hline \multirow{2}{*}{$\mathrm{La}, \mathrm{Ce}$ groups } & $\mathrm{Ce}-144$ & $3.61 \mathrm{E}+07$ & $1.50 \mathrm{E}+07$ \\
\hline $\mathrm{Pu}, \mathrm{actinides}$ & $\mathrm{La}-140$ & $3.33 \mathrm{E}+07$ & $9.71 \mathrm{E}+06$ \\
\hline & $\mathrm{Pu}-239$ & $4.66 \mathrm{E}+03$ & $1.94 \mathrm{E}+03$ \\
\hline
\end{tabular}




\subsection{Tristructural-isotropic (TRISO) Fuel Fabrication Quality}

The level of defects in tristructural isotropic (TRISO) fuel (or the fuel "quality") resulting from the fuel fabrication process is important in establishing the overall source term for an HTGR. Specifications are placed on fuel fabrication to limit the levels of heavy metal contamination and SiC coating defects so that overall radionuclide control requirements are met. The values selected for heavy metal contamination (within the matrix that is not coated) and $\mathrm{SiC}$ defects (in the multiple coatings of each particle) reflect current fuel fabrication experience in the United States. The heavy metal contamination fractions are the same as those used historically by U.S. reactor designers in their design assessments. The SiC coating defect fractions are about 5 times lower than those historically required by the reactor designer. ${ }^{7}$ A lower SiC coating defect level results in a lower metallic fission product (e.g., cesium and strontium) release into the graphite and fuel matrix during normal operation. The fuel defect fraction estimates are presented in Table 3 and were assumed to be normally distributed.

Table 3. Fuel defect fractions for all reactor configurations.

\begin{tabular}{|c|c|c|c|c|}
\hline \multirow{3}{*}{$\begin{array}{c}\begin{array}{c}\text { Fission Product } \\
\text { Class }\end{array} \\
\text { Confidence Limit }\end{array}$} & \multicolumn{4}{|c|}{ Fabrication } \\
\hline & \multicolumn{2}{|c|}{$\begin{array}{c}\text { Fraction Heavy Metal } \\
\text { Contamination }\end{array}$} & \multicolumn{2}{|c|}{$\begin{array}{c}\text { Fraction SiC Coating } \\
\text { Defects }\end{array}$} \\
\hline & $50 \%$ & $95 \%$ & $50 \%$ & $95 \%$ \\
\hline Noble Gases & $1 \mathrm{E}-5$ & $2 \mathrm{E}-5$ & NA & NA \\
\hline $\mathrm{I}, \mathrm{Br}, \mathrm{Se}, \mathrm{Te}$ & $1 \mathrm{E}-5$ & $2 \mathrm{E}-5$ & NA & NA \\
\hline $\mathrm{Cs}, \mathrm{Rb}$ & $1 \mathrm{E}-5$ & $2 \mathrm{E}-5$ & $1 \mathrm{E}-5$ & $3 \mathrm{E}-5$ \\
\hline $\mathrm{Sr}, \mathrm{Ba}, \mathrm{Eu}$ & $1 \mathrm{E}-5$ & $2 \mathrm{E}-5$ & $1 \mathrm{E}-5$ & $3 \mathrm{E}-5$ \\
\hline $\mathrm{Ag}, \mathrm{Pd}$ & $1 \mathrm{E}-5$ & $2 \mathrm{E}-5$ & $1 \mathrm{E}-5$ & $3 \mathrm{E}-5$ \\
\hline $\mathrm{Sb}$ & $1 \mathrm{E}-5$ & $2 \mathrm{E}-5$ & $1 \mathrm{E}-5$ & $3 \mathrm{E}-5$ \\
\hline $\mathrm{Mo}, \mathrm{Ru}, \mathrm{Rh}, \mathrm{Tc}$ & $1 \mathrm{E}-5$ & $2 \mathrm{E}-5$ & $1 \mathrm{E}-5$ & $3 \mathrm{E}-5$ \\
\hline $\mathrm{La}, \mathrm{Ce}$ & $1 \mathrm{E}-5$ & $2 \mathrm{E}-5$ & $1 \mathrm{E}-5$ & $3 \mathrm{E}-5$ \\
\hline $\mathrm{Pu}$, actinides & $1 \mathrm{E}-5$ & $2 \mathrm{E}-5$ & $1 \mathrm{E}-5$ & $3 \mathrm{E}-5$ \\
\hline
\end{tabular}

\subsection{Fission Product Release from Fuel/Graphite during Normal Operation}

As discussed in the MST white paper, the normal operations source terms for modular HTGRs are developed from four major sources: (1) heavy metal contamination in the fuel, (2) particles with SiC coating defects (which release fission metals but not fission gases and halogens), (3) incremental in-service fuel failures that occur under normal operation; and (4) diffusional release through intact coatings. Fuel failure is defined as a loss of the specified retention capability of all the coating layers. However, significant retention of radionuclides is maintained with the kernel, which is accounted for in the analysis. Reactor designers calculate fuel performance accounting for some incremental level of particle coating degradation and failures. The fuel qualification program will provide actual data on a large statistically significant population of TRISO fuel particles to better quantify this value.

Even for similar reactor sizes, HTGR source terms vary depending upon reactor type, thermal power rating, and outlet temperature. For this study, the evaluation assumed the pebble bed designs had a peak normal operating fuel temperature that is 100 to $150^{\circ} \mathrm{C}$ lower than that for a prismatic reactor at the same power rating. Additionally, the higher outlet temperature designs have higher fuel temperatures and higher average core temperatures, which results in a higher normal operational source term, a greater amount of potential incremental fuel failure during normal operation, and a larger inventory of fission 
products captured in the graphite and circulating in the primary coolant. These effects were accounted for in the analysis.

To account for uncertainty in fuel and barrier performance, the review team estimated $50 \%$ and $95 \%$ confidence values for the incremental in-service failure fractions and attenuation factors upon which the mechanistic source terms are based. Incremental in-service failure fractions were assumed to be normally distributed. Attenuation factors were assumed to be lognormally distributed.

Because of the robust nature of the TRISO fuel, demonstrated through historical German and recent U.S. AGR Program experience, ${ }^{8}$ minimal particle failures are expected under anticipated normal NGNP design service conditions (temperature, burnup, fast fluence). Thus, the particle failure fractions under normal conditions represent statistical lower limits based on testing of fuel as part of the fuel development and qualification program. Because a large amount of fuel will be tested under prototypic conditions, the statistically based failure rate is $7-10$ times less than the historical reactor design requirements, thus reducing the source term associated with incremental particle failures under normal conditions. Table 4 lists the 50 and $95 \%$ incremental fuel failure fraction under normal operation for the fission product classes in a prismatic reactor with a $700^{\circ} \mathrm{C}$ reactor outlet temperature. Appendix A contains a complete listing of normal operations fuel defect fractions for the reactor configurations identified in Table 7.

Table 4. Prismatic $700^{\circ} \mathrm{C}$ ROT incremental fuel failure fractions under normal operations.

\begin{tabular}{|c|c|c|}
\hline \multirow{2}{*}{ Fission Product Class } & \multicolumn{2}{|c|}{$\begin{array}{c}\text { Operations } \\
\text { In-Service Failure }\end{array}$} \\
\hline Confidence Limit & $50 \%$ & $95 \%$ \\
\hline Noble Gases & $7.0 \mathrm{E}-6$ & $2.0 \mathrm{E}-5$ \\
\hline $\mathrm{I}, \mathrm{Br}, \mathrm{Se}, \mathrm{Te}$ & $7.0 \mathrm{E}-6$ & $2.0 \mathrm{E}-5$ \\
\hline $\mathrm{Cs}, \mathrm{Rb}$ & $7.0 \mathrm{E}-6$ & $2.0 \mathrm{E}-5$ \\
\hline $\mathrm{Sr}, \mathrm{Ba}, \mathrm{Eu}$ & $7.0 \mathrm{E}-6$ & $2.0 \mathrm{E}-5$ \\
\hline $\mathrm{Ag}, \mathrm{Pd}$ & $7.0 \mathrm{E}-6$ & $2.0 \mathrm{E}-5$ \\
\hline $\mathrm{Sb}$, & $7.0 \mathrm{E}-6$ & $2.0 \mathrm{E}-5$ \\
\hline $\mathrm{Mo}, \mathrm{Ru}, \mathrm{Rh}, \mathrm{Tc}$ & $7.0 \mathrm{E}-6$ & $2.0 \mathrm{E}-5$ \\
\hline $\mathrm{La}, \mathrm{Ce}$ & $7.0 \mathrm{E}-6$ & $2.0 \mathrm{E}-5$ \\
\hline $\mathrm{Pu}, \mathrm{actinides}$ & $7.0 \mathrm{E}-6$ & $2.0 \mathrm{E}-5$ \\
\hline
\end{tabular}

\subsection{Attenuation Factors during Normal Operations}

Attenuation factors (AF) represent the retention capability of each barrier to fission product release. These AFs were estimated by the expert panel based on HTGR fuel testing results and radionuclide transport predictions developed for previous HTGR designs such as the modular high temperature gascooled reactor (MHTGR) and Pebble Bed Modular Reactor (PBMR). In developing the values, the experts accounted for (a) the plant configuration, (b) the design service conditions; and (c) the current fuel knowledge database (e.g., diffusion coefficients in the different layers and materials) and its associated uncertainties. For the noble gases, AFs associated with the matrix, graphite blocks (prismatic only), and the helium pressure boundary (HPB) were set to 1 (no retention). Of the fission products released to the coolant with the helium pressure boundary, noble gases were assumed to remain in circulation $(\mathrm{AF}=1)$, while all others were assumed to plate out in the HPB during normal operation.

For the pebble bed HTGR cases, the lower normal operating fuel temperature results in higher attenuation factors associated with heavy metal contamination, the kernel, and diffusive releases. However, the pebble bed does not have fuel element graphite, so the total fuel element AFs are lower, 
reflecting the lower fission product retentiveness of the fuel matrix of the pebble spheres compared to that of the combined prismatic fuel matrix of the compacts and the fuel element graphite.

In general, higher outlet temperatures tend to increase projected particle failure and decrease the incore retention of the fission products. Thus, a larger inventory of fission products is released from the core and helium pressure boundary, and the reactor building plays a more important role in mitigating the release to the environment.

Table 5 lists the 50 and $95 \%$ confidence $\mathrm{AFs}$ for a prismatic reactor with a $700^{\circ} \mathrm{C}$ ROT under normal operations. Appendix A contains the complete listing of attenuation factors under normal operations for the reactor configurations identified in Table 7.

Table 5. Prismatic $700^{\circ} \mathrm{C}$ ROT barrier attenuation factors during normal operations.

\begin{tabular}{|c|c|c|c|c|c|c|c|c|c|c|}
\hline \multirow{2}{*}{$\begin{array}{c}\begin{array}{c}\text { Fission Product } \\
\text { Class }\end{array} \\
\text { Confidence Limit }\end{array}$} & \multicolumn{2}{|c|}{$\begin{array}{l}\text { Heavy Metal } \\
\text { Contamination }\end{array}$} & \multicolumn{2}{|c|}{$\begin{array}{c}\text { Fuel Particle } \\
\text { Kernel }\end{array}$} & \multicolumn{2}{|c|}{$\begin{array}{l}\text { Diffusive Release } \\
\text { through Fuel } \\
\text { Particle Coatings }\end{array}$} & \multicolumn{2}{|c|}{$\begin{array}{c}\text { Graphite } \\
\text { (Compact } \\
\text { Matrix and } \\
\text { Fuel Element) }\end{array}$} & \multicolumn{2}{|c|}{$\begin{array}{c}\text { Helium Pressure } \\
\text { Boundary }\end{array}$} \\
\hline & $\begin{array}{c}\mathrm{AF} \\
50 \%\end{array}$ & $\begin{array}{c}\mathrm{AF} \\
95 \%\end{array}$ & $\begin{array}{l}\mathrm{AF} \\
50 \%\end{array}$ & $\begin{array}{c}\mathrm{AF} \\
95 \%\end{array}$ & $\begin{array}{c}\mathrm{AF} \\
50 \%\end{array}$ & $\begin{array}{c}\mathrm{AF} \\
95 \%\end{array}$ & $\begin{array}{c}\mathrm{AF} \\
50 \%\end{array}$ & $\begin{array}{c}\mathrm{AF} \\
95 \%\end{array}$ & $\begin{array}{l}\mathrm{AF} \\
50 \%\end{array}$ & $\begin{array}{c}\mathrm{AF} \\
95 \%\end{array}$ \\
\hline Noble Gases & 10 & 3 & 50 & 17 & $1 \mathrm{E} 8$ & $1 \mathrm{E} 7$ & 1 & 1 & 1 & 1 \\
\hline $\mathrm{I}, \mathrm{Br}, \mathrm{Se}, \mathrm{Te}$ & 10 & 3 & 50 & 17 & $1 \mathrm{E} 8$ & $1 \mathrm{E} 7$ & 1 & 1 & $1 \mathrm{E} 6$ & $1 \mathrm{E} 5$ \\
\hline $\mathrm{Cs}, \mathrm{Rb}$ & 1 & 1 & 3 & 1 & $1 \mathrm{E} 8$ & 1E6 & 5 & 2 & $1 \mathrm{E} 6$ & $1 \mathrm{E} 5$ \\
\hline $\mathrm{Sr}, \mathrm{Ba}, \mathrm{Eu}$ & 1 & 1 & 50 & 20 & $1 \mathrm{E} 3$ & 200 & $1 \mathrm{E} 3$ & 300 & $1 \mathrm{E} 6$ & $1 \mathrm{E} 5$ \\
\hline $\mathrm{Ag}, \mathrm{Pd}$ & 1 & 1 & 2 & 1 & $500^{\mathrm{a}}$ & $100^{\mathrm{a}}$ & 2 & 1 & $1 \mathrm{E} 6$ & $1 \mathrm{E} 5$ \\
\hline $\mathrm{Sb}$ & 1 & 1 & 2 & 1 & $1 \mathrm{E} 8$ & 1E6 & 20 & 2 & $1 \mathrm{E} 6$ & $1 \mathrm{E} 5$ \\
\hline $\mathrm{Mo}, \mathrm{Ru}, \mathrm{Rh}, \mathrm{Tc}$ & 1 & 1 & 500 & 30 & $1 \mathrm{E} 8$ & $1 \mathrm{E} 7$ & $1 \mathrm{E} 3$ & 300 & $1 \mathrm{E} 6$ & 1E5 \\
\hline $\mathrm{La}, \mathrm{Ce}$ & 1 & 1 & 500 & 30 & $1 \mathrm{E} 8$ & $1 \mathrm{E} 7$ & $1 \mathrm{E} 3$ & 300 & $1 \mathrm{E} 6$ & 1E5 \\
\hline $\mathrm{Pu}$, actinides & 1 & 1 & $1 \mathrm{E} 3$ & 100 & $1 \mathrm{E} 8$ & $1 \mathrm{E} 7$ & $1 \mathrm{E} 4$ & $1 \mathrm{E} 3$ & $1 \mathrm{E} 6$ & $1 \mathrm{E} 5$ \\
\hline
\end{tabular}

Table 6 compares the mean values for I-131, Cs-137, and Sr-90 inventories retained in the fuel matrix and graphite for an equilibrium core and circulating in the HPB (after a 60-year lifetime) under normal operations for the reactor configurations identified in Table 7. In the two prismatic configurations, the proportional effect of the higher outlet temperature on the inventory of fission products retained in the fuel matrix and graphite and released to the coolant system is evident. For the higher outlet temperature case, the attenuation factors are reduced, reflecting the fact that the core is hotter on average relative to the $700^{\circ} \mathrm{C}$ outlet temperature case. This results in greater release of fission products from the fuel, greater inventory in the fuel matrix and graphite for cesium and strontium, and a greater inventory in the coolant system. The pebble bed design, with a lower power rating and a lower outlet temperature, has correspondingly lower inventories, despite having a lower graphite attenuation factor than the prismatic reactor. 
Table 6. Mean values for I-131, Cs-137, and Sr-90 inventories (curies) released to the helium pressure boundary and retained in the fuel matrix and graphite.

\begin{tabular}{|l|c|c|c|c|c|c|}
\hline \multirow{2}{*}{$\begin{array}{c}\text { Reactor Design } \\
\text { Configuration }\end{array}$} & \multicolumn{2}{|c|}{ I-131, Curies } & \multicolumn{2}{c|}{ Cs-137, Curies } & \multicolumn{2}{c|}{ Sr-90, Curies } \\
\cline { 2 - 7 } & $\begin{array}{c}\text { In Fuel } \\
\text { Grix and }\end{array}$ & $\begin{array}{c}\text { In Helium } \\
\text { Pressure } \\
\text { Boundary }\end{array}$ & $\begin{array}{c}\text { In Fuel } \\
\text { Matrix and } \\
\text { Graphite }\end{array}$ & $\begin{array}{c}\text { In Helium } \\
\text { Pressure } \\
\text { Boundary }\end{array}$ & $\begin{array}{c}\text { In Fuel } \\
\text { Matrix } \\
\text { and } \\
\text { Graphite }\end{array}$ & $\begin{array}{c}\text { In Helium } \\
\text { Pressure } \\
\text { Boundary }\end{array}$ \\
\hline $\begin{array}{l}600 \mathrm{MW}(\mathrm{t}) \text { Prismatic } \\
700^{\circ} \mathrm{C} \text { ROT }\end{array}$ & - & 30 & 24 & 5 & 2750 & 0.1 \\
\hline $\begin{array}{l}600 \mathrm{MW}(\mathrm{t}) \text { Prismatic } \\
900^{\circ} \mathrm{C} \mathrm{ROT}\end{array}$ & - & 74 & 226 & 254 & 5680 & 31 \\
\hline $\begin{array}{l}250 \mathrm{MW}(\mathrm{t}) \text { Pebble } \\
\mathrm{Bed} 700^{\circ} \mathrm{C} \text { ROT }\end{array}$ & - & 9 & 34 & 3 & 1250 & 0.4 \\
\hline
\end{tabular}

\subsection{Accidents Selected for Evaluation}

Based on safety analyses performed for prior gas-cooled reactor studies, breaks in the HPB and water ingress events pose the greatest challenges with respect to offsite dose consequences. As discussed further in Appendix A, previous analyses of these events were reviewed to aid in developing the scenarios to be considered in this model for evaluating the mechanistic source terms. The results from these past assessments also provided additional data for the expert panel to estimate barrier performance and against which the panel's intermediate results were benchmarked. The two scenarios developed and key conditions are summarized here:

- Break in HPB with loss of forced cooling

- $\quad$ Leak or break in the HPB piping up to the largest connecting pipe

- Reactor trip

- Loss of heat transport to the energy conversion

- Loss of shutdown cooling

- Immediate depressurization of helium in the helium pressure boundary

- Opening of the reactor building vent to relieve helium pressure

This event included an early release of the circulating activity with liftoff of plated out material from the HPB due to the depressurization followed by a subsequent long term release because of the core heatup from the fuel and graphite and then from the helium pressure boundary.

- Water ingress event (for design configurations with a steam generator)

- Steam generator tube break

- Reactor trip

- Loss of heat transport to the energy conversion

- Loss of shutdown cooling

- Detection of water ingress

- Isolation of the steam generator main steam and feedwater lines

- Over-pressurization of the HPB through the vessel system relief valve 
- Opening of the reactor building vent to relieve helium and water/steam pressure.

This event included an early release of the circulating activity with washoff of plated out material from the HPB due to the over-pressurization followed by a subsequent long term release due to the core heatup from the fuel and graphite and then from the HPB.

The barrier performance characteristics required as input in the model simulations for these scenarios were then established to be representative of the significant accidents based on knowledge of the requisite phenomenology and results from similar events previously analyzed in HTGR safety assessments.

A third key scenario that has been determined to be risk-significant in prior analyses of the MHTGR and the PBMR, and that was initially considered by the NGNP expert panel, was a small HPB leak followed by a depressurized conduction cooldown. In this event, the HPB depressurization extends for up to several hundred hours, which provides a transport mechanism for the delayed radionuclide release from the fuel as a result of the core heatup but this event does not include the release of plateout material within the helium pressure boundary. The working group bounded this event in the accidents analyzed by including the initial release of plateout material due to lift off and the release of radionuclides due to core heatup following the depressurization phase (even in the absence of a strong driving mechanism for the release). The analysis further assumed shorter release durations, which resulted in higher atmospheric dispersion $(\mathrm{X} / \mathrm{Q})$ values than would be expected for a release lasting many hours. Thus, the working group decided that for the very unlikely event of a small leak without mitigative actions taking place, such as restart of forced cooling and/or intentional helium depressurization through the helium purification system to helium storage, the event would be adequately addressed by the analyzed break scenario and was not selected for further study as part of this initial evaluation.

Based on the proposed HTGR configurations and the selected accident scenarios, five separate model simulations were evaluated. The configurations for each of the simulation are presented in Table 7.

Table 7. Mechanistic source term events for model simulations.

\begin{tabular}{|l|l|}
\hline \multicolumn{1}{|c|}{ Reactor Configuration } & \multicolumn{1}{c|}{ Accident Scenario } \\
\hline $600 \mathrm{MW}(\mathrm{t})$ Prismatic, $700^{\circ} \mathrm{C}$ ROT & Break in Helium Pressure Boundary \\
\hline $600 \mathrm{MW}(\mathrm{t})$ Prismatic, $700^{\circ} \mathrm{C}$ ROT & Water Ingress Event \\
\hline $600 \mathrm{MW}(\mathrm{t})$ Prismatic, $900^{\circ} \mathrm{C}$ ROT & Break in Helium Pressure Boundary \\
\hline $250 \mathrm{MW}(\mathrm{t})$ Pebble Bed, $700^{\circ} \mathrm{C}$ ROT & Break in Helium Pressure Boundary \\
\hline $250 \mathrm{MW}(\mathrm{t})$ Pebble Bed, $700^{\circ} \mathrm{C}$ ROT & Water Ingress Event \\
\hline
\end{tabular}

The model inputs and simulation results presented in the body of this report are for a break in the $\mathrm{HPB}$ in a $600 \mathrm{MW}(\mathrm{t})$ prismatic reactor with an outlet temperature of $700^{\circ} \mathrm{C}$. The model inputs are presented in Appendices A and B and the results are presented in Appendices C and D for all the reactor configurations and selected accident scenarios identified in Table 7.

\subsection{Releases and Attenuation Factors Under Accident Conditions}

For modeling the accident conditions identified in Section 3, the mechanistic source term is assumed to comprise two distinct phases: a short-term (prompt) release during depressurization of the fission products from normal operations, and a long-term (delayed) release primarily due to heatup of the fuel.

For the prompt release, the entire inventory of circulating activity (noble gases) is assumed to be released, and a portion of the material plated out within the HPB is assumed to be lifted off (in the event of a dry break in the helium pressure boundary) or washed off (in a water ingress event). Table 8 lists the 
short-term 50 and $95 \%$ confidence AFs estimated for the HPB and the reactor building for a $600 \mathrm{MW}(\mathrm{t})$ prismatic reactor with a $700^{\circ} \mathrm{C}$ ROT under a break in the HPB accident scenario. Appendix A contains the complete listing of short-term attenuation factors estimated by the expert team for the reactor configurations and selected accident conditions identified in Table 7.

Table 8. Prismatic $700^{\circ} \mathrm{C}$ ROT short-term accident attenuation factors for a break in $\mathrm{He}$ pressure boundary.

\begin{tabular}{|l|c|c|c|c|}
\hline \multirow{2}{*}{ Fission Product Class } & \multicolumn{4}{|c|}{$\begin{array}{c}\text { Break in the } \\
\text { Helium Pressure Boundary }\end{array}$} \\
\cline { 2 - 5 } & \multicolumn{3}{|c|}{$\begin{array}{c}\text { Helium Pressure } \\
\text { Boundary - liftoff }\end{array}$} & Reactor Building \\
\hline Confidence Limit & AF 50\% & AF 95\% & AF 50\% & AF 95\% \\
\hline Noble Gases & 1 & 1 & 1 & 1 \\
\hline $\mathrm{I}, \mathrm{Br}, \mathrm{Se}, \mathrm{Te}$ & 200 & 20 & 2 & 1 \\
\hline $\mathrm{Cs}, \mathrm{Rb}$ & 200 & 20 & 2 & 1 \\
\hline $\mathrm{Sr}, \mathrm{Ba}, \mathrm{Eu}$ & 200 & 20 & 2 & 1 \\
\hline $\mathrm{Ag}, \mathrm{Pd}$ & 200 & 20 & 2 & 1 \\
\hline $\mathrm{Sb}$ & 200 & 20 & 2 & 1 \\
\hline $\mathrm{Mo}, \mathrm{Ru}, \mathrm{Rh}, \mathrm{Tc}$ & 200 & 20 & 2 & 1 \\
\hline $\mathrm{La}, \mathrm{Ce}$ & 200 & 20 & 2 & 1 \\
\hline $\mathrm{Pu}, \mathrm{actinides}$ & 200 & 20 & 2 & 1 \\
\hline
\end{tabular}

The AF estimated for the early depressurization phase in the break in the helium boundary scenario is based on the shear force ratio on surfaces of the HPB and is based on results from the COMEDIE in-pile loop tests. ${ }^{9}$ The COMEDIE tests indicated an AF of 1000 at a shear ratio of 1.7. Since this is a shear ratio higher than calculated for HPB breaks in modular HTGR designs, the 50\% value of 200 used here is judged to be acceptable in light of the lack of detailed plant configuration and design.

For the long-term release, the core is assumed to heat up for 50 hours, after which time a release of nuclides is assumed for the next 40 hours. Table 9 lists the long term 50\% and 95\% AFs for a $600 \mathrm{MW}(\mathrm{t})$ prismatic reactor with a $700^{\circ} \mathrm{C}$ ROT under a HPB break accident scenario.

Additionally, Table 9 also lists the 50\% and 95\% incremental fuel failure under accident conditions. The incremental particle failure fractions under accident conditions represent statistical lower limits based on anticipated testing of fuel as part of the fuel development and qualification program. Because a large amount of fuel will be tested under prototypic conditions, the statistically based failure rate is 7 to 10 times less than the historical reactor design requirements, thus reducing the source term associated with incremental particle failures under accident conditions. Under accident conditions, intact fuel particles do not release fission products except silver. Releases from the core under accidents are dominated by release from heavy metal contamination, in-service incremental failures, and release of fission products retained in the graphite under normal operation. Appendix A contains the long-term incremental release and attenuation factors as estimated by the expert team for the reactor configurations and selected accident conditions identified in Table 7.

Under the accident scenario of a break in the helium pressure boundary, the AF of the HPB for a long-term heat up was reduced relative to the AF under prompt release conditions. The long-term accident AFs take into account the very low flows expected at this phase of the event and the eventual 
contraction of the helium in the reactor vessel as the core cools down and the flow reverses into the helium pressure boundary. Preliminary calculations performed by PBMR for a medium break scenario suggest that AFs greater than 750 are achievable due to the lack of pressure driving force for radionuclide transport from the core through the HPB into the reactor building. In the cases where there is a pressure driving force (such as a very small break) the AF was only 1.7. ${ }^{10}$ Thus, the AFs of 5-10 in Table 9 were also judged to be acceptable estimates given the limited knowledge associated with the accident phenomenology and design detail available.

Table 9. Prismatic $700^{\circ} \mathrm{C}$ ROT long-term accident release and attenuation factors for a break in helium pressure boundary.

\begin{tabular}{|c|c|c|c|c|c|c|c|c|c|c|c|c|c|c|}
\hline \multirow{3}{*}{$\begin{array}{c}\text { Fission } \\
\text { Product Class } \\
\begin{array}{c}\text { Confidence } \\
\text { Limit }\end{array} \\
\end{array}$} & \multirow{2}{*}{\multicolumn{2}{|c|}{$\begin{array}{c}\text { Accident } \\
\text { Release } \\
\text { Incremental } \\
\text { Failure- } \\
\text { Accident }\end{array}$}} & \multicolumn{12}{|c|}{ Attenuation Factors } \\
\hline & & & \multicolumn{2}{|c|}{$\begin{array}{c}\text { Heavy Metal } \\
\text { Accident } \\
\text { Release }\end{array}$} & \multicolumn{2}{|c|}{$\begin{array}{c}\text { Non-Intact } \\
\text { Accident } \\
\text { Release }\end{array}$} & \multicolumn{2}{|c|}{$\begin{array}{c}\text { Intact } \\
\text { Accident } \\
\text { Release }\end{array}$} & \multicolumn{2}{|c|}{ Graphite } & \multicolumn{2}{|c|}{$\begin{array}{c}\text { Helium } \\
\text { Pressure } \\
\text { Boundary }\end{array}$} & \multicolumn{2}{|c|}{$\begin{array}{l}\text { Reactor } \\
\text { Building }\end{array}$} \\
\hline & $50 \%$ & $95 \%$ & $\begin{array}{c}\mathrm{AF} \\
50 \% \\
\end{array}$ & $\begin{array}{c}\mathrm{AF} \\
95 \% \\
\end{array}$ & $\begin{array}{c}\mathrm{AF} \\
50 \% \\
\end{array}$ & $\begin{array}{c}\mathrm{AF} \\
95 \% \\
\end{array}$ & $\begin{array}{c}\mathrm{AF} \\
50 \% \\
\end{array}$ & $\begin{array}{c}\mathrm{AF} \\
95 \% \\
\end{array}$ & $\begin{array}{c}\mathrm{AF} \\
50 \% \\
\end{array}$ & $\begin{array}{c}\mathrm{AF} \\
95 \% \\
\end{array}$ & $\begin{array}{c}\mathrm{AF} \\
50 \% \\
\end{array}$ & $\begin{array}{c}\mathrm{AF} \\
95 \%\end{array}$ & $\begin{array}{c}\mathrm{AF} \\
50 \% \\
\end{array}$ & $\begin{array}{c}\mathrm{AF} \\
95 \% \\
\end{array}$ \\
\hline Noble Gases & $3 \mathrm{E}-5$ & $8 \mathrm{E}-5$ & 2 & 1 & 10 & 5 & 1E7 & 2E6 & 1 & 1 & 5 & 2 & 1 & 1 \\
\hline $\mathrm{I}, \mathrm{Br}, \mathrm{Se}, \mathrm{Te}$ & $3 \mathrm{E}-5$ & $8 \mathrm{E}-5$ & 2 & 1 & 10 & 5 & $1 \mathrm{E} 7$ & 2E6 & 1 & 1 & 5 & 2 & 10 & 2 \\
\hline $\mathrm{Cs}, \mathrm{Rb}$ & $3 \mathrm{E}-5$ & $8 \mathrm{E}-5$ & 1 & 1 & 1 & 1 & $1 \mathrm{E} 7$ & 2E6 & 10 & 3 & 10 & 3 & 10 & 2 \\
\hline $\mathrm{Sr}, \mathrm{Ba}, \mathrm{Eu}$ & $3 \mathrm{E}-5$ & $8 \mathrm{E}-5$ & 1 & 1 & 1 & 1 & $1 \mathrm{E} 6$ & $2 \mathrm{E} 5$ & 100 & 30 & 10 & 3 & 10 & 2 \\
\hline $\mathrm{Ag}, \mathrm{Pd}$ & $3 \mathrm{E}-5$ & $8 \mathrm{E}-5$ & 1 & 1 & 1 & 1 & 500 & 100 & 1 & 1 & 10 & 3 & 10 & 2 \\
\hline $\mathrm{Sb}$ & $3 \mathrm{E}-5$ & $8 \mathrm{E}-5$ & 1 & 1 & 1 & 1 & 1E6 & $2 \mathrm{E} 5$ & 100 & 30 & 10 & 3 & 10 & 2 \\
\hline Mo, Ru, Rh, Tc & $3 \mathrm{E}-5$ & $8 \mathrm{E}-5$ & 1 & 1 & 100 & 50 & $1 \mathrm{E} 7$ & 2E6 & 10 & 3 & 10 & 3 & 10 & 2 \\
\hline $\mathrm{La}, \mathrm{Ce}$ & $3 \mathrm{E}-5$ & $8 \mathrm{E}-5$ & 1 & 1 & 100 & 50 & $1 \mathrm{E} 7$ & 2E6 & 100 & 30 & 10 & 3 & 10 & 2 \\
\hline $\mathrm{Pu}$, actinides & $3 \mathrm{E}-5$ & $8 \mathrm{E}-5$ & 1 & 1 & 1E3 & 500 & 1E7 & 2E6 & $1 \mathrm{E} 4$ & 300 & 10 & 3 & 10 & 2 \\
\hline
\end{tabular}

In the break in the HPB scenarios, the reactor building AF of 10 was judged to be acceptable in light of the lack of building design and the desire to focus the reactor building requirements on structural protection of the reactor as opposed to radionuclide retention. The PBMR calculations indicate long term AFs in excess of 2000 for a medium size break and 20 for a very small break may be achieved. In these calculations, the reactor building was assumed to leak at $100 \%$ per day at 0.1 bar overpressure. As such, the AFs are not associated with any specific fission product retention mechanisms or leak tightness of the reactor building but rather with the lack of any strong flow to transport the gas through the reactor building to the environment.

In the case of the water ingress event, the uncertainties are larger because of the lack of data. However, because the water is expected to remove a large fraction of the plateout inventory, the AFs for the HPB were set much lower than in the HPB break case. Because condensation of the moisture in the reactor building during transport is expected to mitigate the escape of fission products from the building, a higher AF was estimated for the reactor building. As discussed above, in general, the AFs for the reactor building $(\mathrm{RB})$ were selected to allow flexibility in the final design details to accomplish the primary function of the building to provide structural protection of the reactor to maintain core geometry for control of heat generation and core heat removal to the reactivity cavity cooling system (RCCS). Thus, the AFs are not overly aggressive for the RB's supportive function of radionuclide retention. 


\subsection{Source Terms}

Using the attenuation factors and modeling assumptions discussed in the previous sections, mechanistic source terms (release from the reactor building) were estimated for the short term and long term releases for each reactor configuration identified in Section 3. Table 10 lists the 50\%, mean, and $95 \%$ source term values for a $600 \mathrm{MW}(\mathrm{t})$ prismatic reactor with a $700^{\circ} \mathrm{C}$ ROT under the HPB break accident scenario. Source term values are presented in curies. Appendix B contains the source terms for the other reactor configurations identified in Table 7.

Table 10. $600 \mathrm{MW}(\mathrm{t})$ Prismatic $700^{\circ} \mathrm{C}$ ROT, source terms for a break in He pressure boundary.

\begin{tabular}{|c|c|c|c|c|c|c|c|}
\hline \multirow{2}{*}{$\begin{array}{l}\text { Fission Product } \\
\text { Class }\end{array}$} & \multirow{2}{*}{ Nuclide } & \multicolumn{3}{|c|}{ Short Term Release (curies) } & \multicolumn{3}{|c|}{ Long Term Release (curies) } \\
\hline & & $50 \%$ & Mean & $95 \%$ & $50 \%$ & Mean & $95 \%$ \\
\hline \multirow{3}{*}{ Noble Gases } & Xe-133 & $3.99 \mathrm{E}+01$ & $3.99 \mathrm{E}+01$ & $3.99 \mathrm{E}+01$ & 4.92E+01 & $6.44 \mathrm{E}+01$ & $1.68 \mathrm{E}+02$ \\
\hline & $\mathrm{Kr}-85$ & $2.10 \mathrm{E}-01$ & $2.10 \mathrm{E}-01$ & $2.10 \mathrm{E}-01$ & $3.39 \mathrm{E}-01$ & $4.50 \mathrm{E}-01$ & $1.21 \mathrm{E}+00$ \\
\hline & $\mathrm{Kr}-88$ & $2.06 \mathrm{E}+01$ & $2.06 \mathrm{E}+01$ & $2.06 \mathrm{E}+01$ & $1.38 \mathrm{E}-04$ & $1.82 \mathrm{E}-04$ & 4.91E-04 \\
\hline \multirow{3}{*}{$\mathrm{I}, \mathrm{Br}, \mathrm{Te}, \mathrm{Se}$} & $\mathrm{I}-131$ & $5.51 \mathrm{E}-02$ & $1.61 \mathrm{E}-01$ & $6.10 \mathrm{E}-01$ & $2.85 \mathrm{E}+00$ & $6.11 \mathrm{E}+00$ & $2.24 \mathrm{E}+01$ \\
\hline & $\mathrm{I}-133$ & $1.00 \mathrm{E}-01$ & $2.90 \mathrm{E}-01$ & $1.08 \mathrm{E}+00$ & $1.17 \mathrm{E}+00$ & $2.64 \mathrm{E}+00$ & $9.72 \mathrm{E}+00$ \\
\hline & Te-132 & 7.44E-02 & $2.17 \mathrm{E}-01$ & $8.08 \mathrm{E}-01$ & $3.12 \mathrm{E}+00$ & $6.51 \mathrm{E}+00$ & $2.41 \mathrm{E}+01$ \\
\hline \multirow{2}{*}{$\mathrm{Cs}, \mathrm{Rb}$} & Cs-137 & $1.17 \mathrm{E}-01$ & $3.43 \mathrm{E}-01$ & $1.33 \mathrm{E}+00$ & $1.15 \mathrm{E}-01$ & $3.31 \mathrm{E}-01$ & $1.28 \mathrm{E}+00$ \\
\hline & Cs-134 & $1.93 \mathrm{E}-02$ & $5.54 \mathrm{E}-02$ & $2.10 \mathrm{E}-01$ & $1.32 \mathrm{E}-01$ & $3.82 \mathrm{E}-01$ & $1.49 \mathrm{E}+00$ \\
\hline $\mathrm{Sr}, \mathrm{Ba}, \mathrm{Eu}$ & Sr-90 & $1.57 \mathrm{E}-03$ & $4.56 \mathrm{E}-03$ & $1.72 \mathrm{E}-02$ & $1.79 \mathrm{E}-01$ & $4.71 \mathrm{E}-01$ & $1.76 \mathrm{E}+00$ \\
\hline \multirow{2}{*}{$\mathrm{Ag}, \mathrm{Pd}$} & $\mathrm{Ag}-110 \mathrm{~m}$ & $3.86 \mathrm{E}-02$ & $1.13 \mathrm{E}-01$ & 4.22E-01 & $8.61 \mathrm{E}-01$ & $2.30 \mathrm{E}+00$ & $8.51 \mathrm{E}+00$ \\
\hline & Ag-111 & $7.96 \mathrm{E}-01$ & $2.28 \mathrm{E}+00$ & $8.93 \mathrm{E}+00$ & $5.48 \mathrm{E}+01$ & $1.72 \mathrm{E}+02$ & $6.49 \mathrm{E}+02$ \\
\hline $\mathrm{Sb}$ & $\mathrm{Sb}-125$ & 7.27E-04 & $2.12 \mathrm{E}-03$ & $8.15 \mathrm{E}-03$ & $1.78 \mathrm{E}-03$ & $5.23 \mathrm{E}-03$ & $2.05 \mathrm{E}-02$ \\
\hline Mo, Ru, Rh, Tc & $\mathrm{Ru}-103$ & $8.05 \mathrm{E}-04$ & $2.34 \mathrm{E}-03$ & $8.68 \mathrm{E}-03$ & 7.19E-01 & $1.96 \mathrm{E}+00$ & $7.54 \mathrm{E}+00$ \\
\hline \multirow{2}{*}{ La, Ce groups } & Ce-144 & $9.74 \mathrm{E}-03$ & $2.75 \mathrm{E}-02$ & $1.05 \mathrm{E}-01$ & 4.57E-02 & $1.30 \mathrm{E}-01$ & $5.01 \mathrm{E}-01$ \\
\hline & La-140 & $7.46 \mathrm{E}-04$ & $2.16 \mathrm{E}-03$ & $8.13 \mathrm{E}-03$ & $2.88 \mathrm{E}-02$ & $7.65 \mathrm{E}-02$ & $2.92 \mathrm{E}-01$ \\
\hline $\mathrm{Pu}$, actinides & Pu-239 & $1.90 \mathrm{E}-07$ & $5.74 \mathrm{E}-07$ & $2.10 \mathrm{E}-06$ & 8.97E-07 & $2.60 \mathrm{E}-06$ & $1.01 \mathrm{E}-05$ \\
\hline
\end{tabular}

This source term assessment has produced release estimates that are lower than have historically been produced by HTGR reactor vendors. The lower estimates presented here are the result of incorporating better fuel performance expectations with lower coated particle fuel defects and lower estimated coated fuel particle failure rates based on current and anticipated data from the AGR program. 


\section{DOSE CONVERSION FACTORS}

To support the parametric model, a series of calculations was performed with MACCS to generate a set of distance-weighted dose conversion factors (rem/curie) at distances of 400, 800, 1600, 3200, and 8000 meters [3] for the exposure protocols identified in Table 11.

\subsection{Meteorology}

The meteorology for this analysis was based on data from the report, "Engineering Evaluation of $\chi / \mathrm{Q}$ Values Consistent with Regulatory Guide 1.145."5 The atmospheric dispersion factors ( $\chi / \mathrm{Q}$ values) were determined at the specified downwind distances for a hypothetical ground-level release using meteorological data from a site with the worst case average annual dispersion coefficients. Building wake-effects were not included. For DBA analyses, 95\% values for $\chi / \mathrm{Q}$ were used consistent with NUREG 0800 Standard Review Plan for the Review of Safety Analysis Reports for Nuclear Power Plants, ${ }^{11}$ Section 2.3.4, "Short-Term Atmospheric Dispersion Estimates for Accident Releases." For the PAG analyses, average $\chi / \mathrm{Q}$ values and deposition factors (D/Q values) were used consistent with NUREG 0800, Section 2.3.5, "Long-Term Atmospheric Dispersion Estimates for Routine Releases."

\subsection{Dose Conversion}

Using the standard dose conversion factors listed in the EPA Federal Guidance Technical Reports 11 and 12, MACCS generated a set of distance-weighed dose conversion factors for each exposure scenario. The model used a normalized release of one curie for each key fission product. These distanceweighted dose conversion factors were then multiplied by the source term values presented in Section 3.7 to provide dose estimates in rem. A summary of the distance-weighted dose conversion factors is presented in Appendix C.

Table 11. Dose limits and associated protocols for calculating exposures.

\begin{tabular}{|c|c|c|c|c|c|c|}
\hline Case & Limits & Nuclides & Organ & Exposure & Pathway & Reference \\
\hline \multicolumn{7}{|c|}{ NRC Siting Criteria (95th percentile meteorological conditions) } \\
\hline A & $25 \mathrm{rem}$ & List of nuclides & TEDE & Worst $2 \mathrm{hr}$ & $\begin{array}{l}\text { Cloud-shine, inhalation, } \\
\text { ground-shine }\end{array}$ & $\begin{array}{l}10 \text { CFR 52.47(a) } \\
\text { Exclusion Area Boundary }\end{array}$ \\
\hline $\mathrm{B}$ & $25 \mathrm{rem}$ & List of nuclides & TEDE & $\begin{array}{l}\text { Cloud } \\
\text { Passage }\end{array}$ & $\begin{array}{l}\text { Cloud-shine, inhalation, } \\
\text { ground-shine }\end{array}$ & $\begin{array}{l}10 \text { CFR 52.47(a) } \\
\text { Low Population Zone }\end{array}$ \\
\hline \multicolumn{7}{|c|}{ EPA PAG - Plume Exposure Related Dose (mean meteorological conditions) } \\
\hline $\mathrm{C}$ & $1 \mathrm{rem}$ & List of nuclides & TEDE & 4 days & $\begin{array}{l}\text { Cloud-shine, inhalation, } \\
\text { ground-shine }\end{array}$ & $\begin{array}{l}\text { EPA 400-R-92-001, } \\
\text { Table 2-1 }\end{array}$ \\
\hline $\mathrm{D}$ & $5 \mathrm{rem}$ & $\begin{array}{l}\text { Iodine (I-131, I- } \\
133, \text { Te-132) }\end{array}$ & Thyroid & 4 days & Inhalation & $\begin{array}{l}\text { EPA 400-R-92-001, } \\
\text { Table 2-1 }\end{array}$ \\
\hline \multicolumn{7}{|c|}{ EPA PAG-Ingestion Related Dose (mean meteorological conditions) } \\
\hline $\mathrm{E}$ & $0.5 \mathrm{rem}$ & $\begin{array}{l}\text { List of non-noble } \\
\text { nuclides }\end{array}$ & $\begin{array}{l}\text { Whole body } \\
\text { (Effective) }\end{array}$ & 1 year & $\begin{array}{l}\text { Pasture, cow, milk, } \\
\text { person (infant, adult) }\end{array}$ & $\begin{array}{l}\text { EPA 400-R-92-001, } \\
\text { Chapter } 3 \text { (FR Vol. 47, } \\
\text { No. 205, paragraph [c]) }\end{array}$ \\
\hline $\mathrm{F}$ & $1.5 \mathrm{rem}$ & $\begin{array}{l}\text { List of non-noble } \\
\text { nuclides }\end{array}$ & Thyroid & 1 year & $\begin{array}{l}\text { Pasture, cow, milk, } \\
\text { person (infant, adult) }\end{array}$ & $\begin{array}{l}\text { EPA 400-R-92-001, } \\
\text { Chapter } 3 \text { (FR Vol. 47, } \\
\text { No. 205, paragraph [c]) }\end{array}$ \\
\hline
\end{tabular}




\section{COMPARISON OF RESULTS TO PROJECT OBJECTIVES}

Dose estimates were produced by multiplying source terms by distance-weighted dose conversion factors. Estimates were produced for each combination of reactor configuration, accident scenario, and exposure case. In this section, summaries of the dose estimates are presented for the five scenarios modeled for a receptor located at $400 \mathrm{~m}$ for plume exposures (Cases A-D), and at all analyzed distances for the ingestion pathway (Cases E-F).

For the exposure scenarios $\mathrm{A}$ through $\mathrm{C}$ and $\mathrm{E}$, the dominant contributors to total effective doses for the offsite receptors for the accident scenarios assessed are Ag-111, Ag-110m, and Ce-144. This result is different from results of previous modular HTGR accident analyses. Because of the better fuel performance assumed in this study based on recent encouraging results of fuel R\&D, defect levels and assumed incremental failure rates under normal and accident conditions are lower than used in past modular HTGR accident analyses. This better fuel performance translates into much lower release of Cs137 , the isotope that has historically dominated total effective doses off site. Thus, these silver and cerium isotopes that were minor contributors in the past have shown up as more important now. This result may also be due in part to the simplified methodology used in this study to establish the source term. Enhanced attention to the behavior of these isotopes will be given in the NGNP Technology Development Program going forward.

Inhalation and ingestion doses directly to the thyroid Cases D and F were the primarily the result of I-131.

Appendix $\mathrm{C}$ contains a complete listing of dose estimates for each of the five reactor configurations and selected accident scenarios presented in Table 7.

\subsection{Comparison with NRC Siting Criteria (Cases A and B)}

For comparison with the NRC siting criteria (Cases A - Exclusion Area Boundary and B - Low Population Zone from Table 11) the 95\% mechanistic source term and 95\% distance-weighted dose conversion factors were used. In developing the mechanistic source term, it was conservatively assumed that the reactor building does not retain any fission products released from the helium pressure boundary. The short term and long term accident attenuation factors for the reactor building were set to 1. Even with this assumption, the siting criteria are met at the EAB with large margins for all single module reactor configurations and accident scenarios, as summarized in Table 12 for all scenarios evaluated. These results demonstrate the high degree of radionuclide retention afforded by the fuel matrix and graphite within the core of a modular HTGR.

Table 12. Upper bound comparison with NRC siting criteria (DBA) - (TEDE rem).

\begin{tabular}{|l|l|c|c|}
\hline \multicolumn{1}{|c|}{ Design Configuration } & \multicolumn{1}{|c|}{ Event Scenario } & $\begin{array}{c}\text { Case A, EAB } \\
(400 \mathrm{~m})\end{array}$ & $\begin{array}{c}\text { Case B, LPZ } \\
(400 \mathrm{~m})\end{array}$ \\
\hline $600 \mathrm{MW}(\mathrm{t})$ Prismatic, $700^{\circ} \mathrm{C}$ ROT & Break in Helium Pressure Boundary & 0.02 & 1.32 \\
\hline $600 \mathrm{MW}(\mathrm{t})$ Prismatic, $700^{\circ} \mathrm{C}$ ROT & Water Ingress Event & 0.46 & 6.43 \\
\hline $600 \mathrm{MW}(\mathrm{t})$ Prismatic, $900^{\circ} \mathrm{C}$ ROT & Break in Helium Pressure Boundary & 0.43 & 2.06 \\
\hline $250 \mathrm{MW}(\mathrm{t})$ Pebble Bed, $700^{\circ} \mathrm{C}$ ROT & Break in Helium Pressure Boundary & 0.04 & 0.57 \\
\hline $250 \mathrm{MW}(\mathrm{t})$ Pebble Bed, $700^{\circ} \mathrm{C}$ ROT & Water Ingress Event & 0.86 & 3.33 \\
\hline Limits (rem) & & 25 & 25 \\
\hline
\end{tabular}




\subsection{Comparison with PAG Emergency Planning Criteria (Cases C-F)}

For comparison with the EPA PAG Emergency Planning Criteria (Cases C-F from Table 11), the mean values for mechanistic source term and distance-weighted dose conversion factors were used. The plume exposure PAG criteria of 1 rem (total effective dose equivalent) and 5 rem (inhalation thyroid dose) are shown to be met at the EAB (400 m) for all single module reactor configurations under the evaluated accident scenarios. The results of the dose evaluation at the EAB compared against the plume exposure PAG limits are summarized in Table 13 for all scenarios evaluated.

Table 13. Realistic comparison with plume exposure PAG at EAB.

\begin{tabular}{|l|l|c|c|}
\hline Design Configuration & Event Scenario & $\begin{array}{c}\text { Case C, } \\
\text { TEDE (rem) }\end{array}$ & $\begin{array}{c}\text { Case D, } \\
\text { Thyroid (rem) }\end{array}$ \\
\hline $600 \mathrm{MW}(\mathrm{t})$ Prismatic, $700^{\circ} \mathrm{C}$ ROT & $\begin{array}{l}\text { Break in Helium Pressure } \\
\text { Boundary }\end{array}$ & 0.04 & 0.18 \\
\hline $600 \mathrm{MW}(\mathrm{t})$ Prismatic, $700^{\circ} \mathrm{C}$ ROT & Water Ingress Event & 0.05 & 0.25 \\
\hline $600 \mathrm{MW}(\mathrm{t})$ Prismatic, $900^{\circ} \mathrm{C}$ ROT & $\begin{array}{l}\text { Break in Helium Pressure } \\
\text { Boundary }\end{array}$ & 0.07 & 0.21 \\
\hline $250 \mathrm{MW}(\mathrm{t})$ Pebble Bed, $700^{\circ} \mathrm{C}$ ROT & $\begin{array}{l}\text { Break in Helium Pressure } \\
\text { Boundary }\end{array}$ & 0.02 & 0.07 \\
\hline $250 \mathrm{MW}(\mathrm{t})$ Pebble Bed, $700^{\circ} \mathrm{C}$ ROT & Water Ingress Event & 0.04 & 0.10 \\
\hline Limits (rem) & & 1 & 5 \\
\hline
\end{tabular}

For Cases E and F, the ingestion pathway PAG criteria are met for an adult receptor at 400m. However, for an infant receptor the ingestion pathway PAG criteria of $0.5 \mathrm{rem}$ (whole body) is not met at $400 \mathrm{~m}$, but is met at a distance of less than $800 \mathrm{~m}$. For the infant receptor the ingestion pathway PAG criteria of 5 rem (thyroid) is the limiting case and is not met at $400 \mathrm{~m}$, but is met at a distance of approximately $900 \mathrm{~m}$. The results of the dose evaluation for the ingestion pathway PAG for the infant receptor as a function of distance are presented in Figure 1 and Figure 2 for the whole body and thyroid criteria, respectively. 


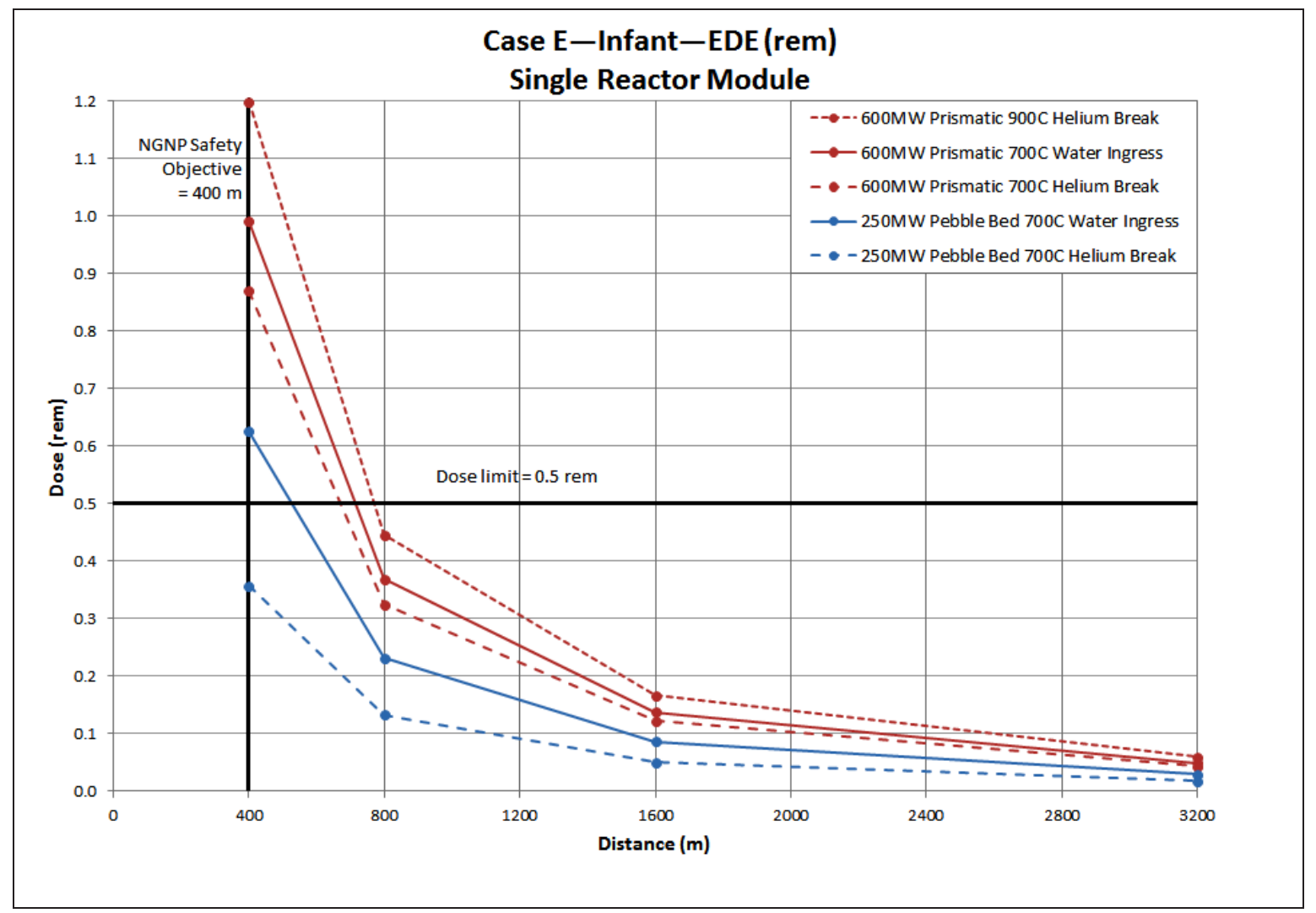

Figure 1. Case E, infant, EDE (rem), single reactor module. 


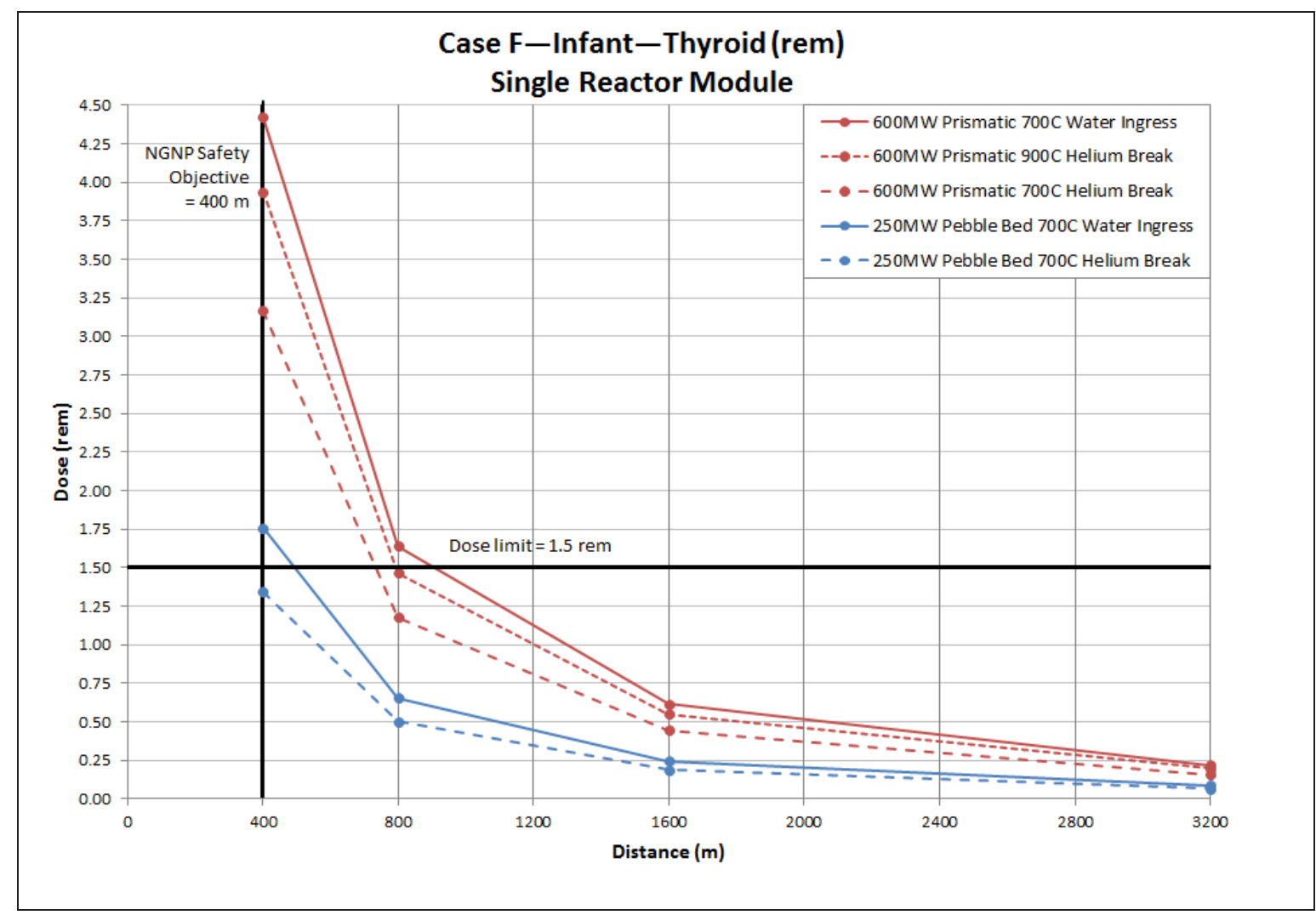

Figure 2. Case F, infant, thyroid (rem) single reactor module.

\subsection{Overall Conclusions}

In summary, the results of this scoping analysis indicate that all NGNP Project objectives related to offsite dose for the NRC Siting and EPA PAG plume exposures (Cases A-D) are met for a single reactor module with the functional containment performance levels that are currently envisioned, and are being validated, in part through the NGNP Technology Development Program. These offsite release results demonstrate the high degree of radionuclide retention afforded by the fuel and graphite within the core of a modular HTGR and support the assertion that no public evacuation or sheltering would be required. However, additional technical assessment and design development work are needed to fully demonstrate that project objectives related to meeting the ingestion pathway EPA PAG (Cases E and F) at or near the EAB are achieved.

Additional analyses will be needed to confirm that project objectives are satisfied for multi-module HTGR facilities when responding to postulated events that may result in fission product releases from more than one module. These additional analyses can be completed when the licensing basis events at multi-module facilities are established. These methods are being developed through ongoing NGNP licensing efforts regarding establishment of the risk informed performance based approach for identifying postulated events. 


\section{REFERENCE}

1. Idaho National Laboratory, Next Generation Nuclear Plant Mechanistic Source Terms White Paper, INL/EXT-10-17997, July 2010.

2. Idaho National Laboratory, Next Generation Nuclear Plant Mechanistic Source Terms White Paper, INL/EXT-10-17997, July 2010.

3. D. Chanin, M. L. Young, J. Randall, and K. Jamali, "Code Manual for MACCS2: Volume 1, User's Guide,” NUREG/CR-6613 (SAND97-0594), May 1998.

4. PNNL-21012, 2011, "MACCS2 Unit Dose Conversion Factors for Use with Next Generation Nuclear Plant Source Term Analysis," Pacific Northwest National Laboratory, Richland, WA, 2011.

5. PNNL 19217, "Engineering Evaluation of X/Q Values Consistent with Regulatory Guide 1.145," Pacific Northwest National Laboratory, Richland, WA, 2010.

6. GA 2008, Engineering Services For The Next Generation Nuclear Plant (NGNP) With Hydrogen Production: NGNP Contamination Control Study; GA Report 911117 April 2008, General Atomics, San Diego CA.

7. C. M. Barnes, and J. D. Hunn, "Fabrication and Comparison of Fuels for Advanced Gas Reactor Tests," $5^{\text {th }}$ International Topical Meeting on High Temperature Reactor Technology (HTR-2010) Prague Czech Republic, Oct 18-20, 2010.

8. S. B. Grover, et al., "Mission and Status of the First Two Next Generation Nuclear Plant Fuel Irradiation Experiments in the Advanced Test Reactor," Proceedings of the $18^{\text {th }}$ International Conference of Nuclear Engineering, Xian China, May 17-20, 2010.

9. W. Medwid and A. Gillespie, COMEDIE BD-1 Test Evaluation Report, DOE, DOE-HTGR-88552, General Atomics, 1993.

10. NGNP-PLD-GEN-RPT-N-00007, "Next Generation Nuclear Plant: Plant Level Assessments Leading to Fission Product Retention Allocations," October 2009, Westinghouse Electric Company LLC, Pittsburgh, PA.

11. NUREG 0800, Standard Review Plan for the Review of Safety Analysis Reports for Nuclear Power Plant, Nuclear Regulatory Commission. 
Appendix A

\section{Expert Review Panel Meeting and Results}




\section{Appendix A \\ Expert Review Panel Meeting and Results}

As a result of discussions on Next Generation Nuclear Plant (NGNP) Research and Development (R\&D) needs, it was recommended that the NGNP Project develop a simplified parametric model as a surrogate to performing detailed accident analysis models in the absence of a selected NGNP Demonstration Plant design. This model establishes scoping source terms based on performance of the NGNP identified barriers in HTGR Mechanistic Source Terms White Paper (INL/EXT-10-17997) and evaluates the impact of these releases to public health.

An expert review process was used to establish defensible and target values for the radionuclide transport factors and necessary input assumptions to develop the mechanistic source term used in the simplified parametric dose analysis model. To facilitate this process, a meeting of the expert panel was convened during the week of September 5, 2011. The agenda and outputs of this meeting are contained as attachments to this appendix. The expert panel consisted of personnel knowledgeable of NGNP Fuel Development Activities, high temperature gas-cooled reactor (HTGR) R\&D activities, past HTGR and light water reactor (LWR) accident analysis, and the proposed NGNP design alternatives and licensing approach for mechanistic source terms.

The team members and their relevant background for this panel topic were:

- David Alberstein: BS - Physics, MS - Nuclear Engineering. 40 years of experience in nuclear energy, including 27 years of experience in HTGR design, licensing, and program management. Former technical lead at General Atomics for analysis of metallic fission product transport in and release from the HTGR core.

- Hans Gougar: BS - Education, Ms and PhD - Nuclear Engineering. 14 years of experience at the INL working in core safety analysis and code development, including 12 years on methods development for HTGRs. Deputy Technical Director for VHTR research and development at the INL. Consultant to the PBMR Company on core analysis methods.

- David Hanson: BS, MS - Chemical Engineering. 40 years of experience in HTGR core performance analysis, TRISO fuel performance, and fission product transport at General Atomics. Prepared numerous umbrella technology development plans, test plans, and test specifications to characterize fuel performance and fission product transport in HTGRs.

- Tom Hicks: Over 30 years of management, licensing, safety, operations, ITAAC and engineering experience. U.S. nuclear submarine program; U.S. Nuclear Regulatory Commission (NRC) inspector; consulting firm director of commercial plant nuclear programs; team leader for nuclear plant inspection teams; COLA licensing support lead/advisory positions for new reactor plants. NGNP Regulatory Affairs - Licensing staff.

- Richard Hobbins: BS - Chemistry, PhD - Metallurgy. 42 years of experience in nuclear fuel development and source terms - 24 years at INL and 18 years as an independent consultant, including 13 years with gas-cooled reactor programs (NPR and NGNP).

- Peter Lowry: BS - Engineering. 20 years of experience in nuclear safety for nuclear reprocessing facilities and reactors. NGNP Engineering Lead for Safety Analysis and Probabilistic Risk Assessment. Member of the Working Group for ANS 53.1 Nuclear Safety Design Process for Modular Helium-Cooled Reactor Plants. 
- Phil Mills: BS - Mechanical Engineering. 27 years of experience in the nuclear industry. Acting Director of NGNP Engineering at the Idaho National Laboratory.

- David Petti: PhD - Nuclear Engineering. 25 years experience in nuclear fuel development and source term analysis. Director of NGNP R\&D at the INL, responsible for the AGR fuel development, testing, and qualification program.

- Fred Silady: BS, MS, PhD - Nuclear Engineering. 38 years of experience in HTGR safety, licensing, and systems engineering Former technical and management lead at General Atomics for deterministic and probabilistic safety analyses. Consultant on modular HTGR design and development to PBMR, AREVA, and General Atomics.

As an initial step, the team reviewed accidents scenarios and attributes (see attached September meeting agenda pages 3-5) to be considered for the initial development of mechanistic source term (release characteristics) within the dose evaluation model. The initial considerations supporting the selection of the accident conditions to be further evaluated are provided below:

\begin{tabular}{|c|c|c|c|c|c|c|c|}
\hline $\begin{array}{c}\text { Event } \\
\text { Descriptor }\end{array}$ & Characteristics & PSID & $\begin{array}{c}\text { AREVA } \\
\text { Safety } \\
\text { Assessment }\end{array}$ & Mission & Core Difference & $\begin{array}{c}\text { Power } \\
\text { Difference }\end{array}$ & $\begin{array}{c}\text { Outlet } \\
\text { Temperature }\end{array}$ \\
\hline $\begin{array}{l}\text { Large } \\
\text { Break }\end{array}$ & $\begin{array}{l}\text { Depressurization time }< \\
1 \text { minute. Initial: } \\
\text { Circulating, Mechanical } \\
\text { Entrainment (liftoff, } \\
\text { dust) long term: air } \\
\text { ingress (enhance matrix } \\
\text { graphite release, impact } \\
\text { on fuel failure) }\end{array}$ & NA & 7.2 .1 & $\begin{array}{l}\text { IHX with } \\
\text { piping - yes } \\
\text { SG } \\
\text { TBD-ASME }\end{array}$ & $\begin{array}{l}\text { PBR More Dust } \\
\text { larger impact of } \\
\text { air }\end{array}$ & $\begin{array}{l}\text { Scalable. } \\
\text { (More of \% } \\
\text { core/ } \\
\text { inventory is } \\
\text { impacted) }\end{array}$ & $\begin{array}{l}\text { More initial } \\
\text { inventory in } \\
\text { matrix/graphite. } \\
\text { Implies IHX } \\
(>800) \text { impact } \\
\text { on Iodine }\end{array}$ \\
\hline $\begin{array}{l}\text { Medium } \\
\text { Break }\end{array}$ & $\begin{array}{l}\text { Depressurization time < } \\
5 \text { minute. Less } \\
\text { Mechanical Entrainment } \\
\text { long term: air ingress } \\
\text { (less - enhanced matrix } \\
\text { graphite release, impact } \\
\text { on fuel failure) }\end{array}$ & DBA-10 & & All & $\begin{array}{l}\text { PBR More Dust } \\
\text { larger impact of } \\
\text { air }\end{array}$ & $\begin{array}{l}\text { Scalable. } \\
\text { (More of \% } \\
\text { core } \\
\text { /inventory is } \\
\text { impacted) }\end{array}$ & $\begin{array}{l}\text { More initial } \\
\text { inventory in } \\
\text { matrix/graphite. } \\
\text { Implies IHX } \\
(>800) \text { impact } \\
\text { on Iodine }\end{array}$ \\
\hline $\begin{array}{l}\text { Small } \\
\text { Break }\end{array}$ & $\begin{array}{l}\text { Depressurization time } \\
\text { hours. 20-30 hrs. Initial } \\
\text { circulating (look at time } \\
\text { phases depressurization, } \\
\text { expansion, and } \\
\text { contraction) }\end{array}$ & DBA-11 & 7.2 .2 & All & $\begin{array}{l}\text { Pebble peaks } \\
\text { sooner - timing } \\
\text { of heat up } \\
\text { release may } \\
\text { overlap with } \\
\text { depressurization }\end{array}$ & $\begin{array}{l}\text { Scalable. } \\
\text { (More of \% } \\
\text { core } \\
\text { /inventory is } \\
\text { impacted) }\end{array}$ & $\begin{array}{l}\text { More initial } \\
\text { inventory in } \\
\text { matrix/graphite. } \\
\text { Implies IHX } \\
(>800) \text { impact } \\
\text { on Iodine }\end{array}$ \\
\hline $\begin{array}{l}\text { Pressurized } \\
\text { Cooldown } \\
\text { with } \\
\text { subsequent } \\
\text { HPB } \\
\text { failure } \\
\end{array}$ & $\begin{array}{l}\text { Breach occurs at peak } \\
\text { heat up. shifts release } \\
\text { phase - timing }\end{array}$ & & & $\begin{array}{l}\text { IHX Process } \\
\text { Heat }\end{array}$ & $\begin{array}{l}\text { Pebble peaks } \\
\text { sooner - timing } \\
\text { of heat up } \\
\text { release may } \\
\text { overlap with } \\
\text { depressurization }\end{array}$ & $\begin{array}{l}\text { Scalable. } \\
\text { (More of \% } \\
\text { core } \\
\text { /inventory is } \\
\text { impacted) }\end{array}$ & $\begin{array}{l}\text { More initial } \\
\text { inventory in } \\
\text { matrix/graphite. } \\
\text { Implies IHX } \\
(>800) \text { impact } \\
\text { on Iodine }\end{array}$ \\
\hline $\begin{array}{l}\text { Water } \\
\text { Ingress }\end{array}$ & $\begin{array}{l}\text { large (PRV cycles, sticks } \\
\text { open) hydrolysis, wash } \\
\text { off, water induced } \\
\text { matrix/graphite release, } \\
\text { reactivity affects }\end{array}$ & DBA-6 & 7.2 .4 & SG only & none & Scalable & $\begin{array}{l}\text { Limited to } \\
<750 \mathrm{C} \text { due to } \\
\mathrm{SG}\end{array}$ \\
\hline
\end{tabular}

Based on safety analyses performed for prior gas-cooled reactor studies, breaks in the HPB and water ingress events pose the greatest challenges with respect to offsite dose consequences. As discussed further in Appendix A, previous analyses of these events were reviewed to aid in developing the scenarios to be considered in this model for evaluating the mechanistic source terms. The results from these past assessments also provided additional data for the expert panel to estimate barrier performance and against which the panel's intermediate results were benchmarked. The two scenarios developed and key conditions are summarized here: 
- Break in helium pressure boundary (HPB) with loss of forced cooling

- a leak or break in the HPB piping up to the largest connecting pipe

- reactor trip

- loss of heat transport to the energy conversion

- loss of shutdown cooling

- immediate depressurization of helium in the helium pressure boundary

- opening of the reactor building vent to relieve helium pressure.

This event included an early release of the circulating activity with liftoff of plated out material from the HPB due to the depressurization followed by a subsequent long term release due to the core heatup from the fuel and graphite and then from the helium pressure boundary.

- Water Ingress Event (for design configurations with a steam generator)

- $\quad$ steam generator tube break

- reactor trip

- loss of heat transport to the energy conversion

- loss of shutdown cooling

- detection of water ingress

- isolation of the steam generator main steam and feedwater lines

- over-pressurization of the HPB through the vessel system relief valve

- opening of the reactor building vent to relieve helium and water/steam pressure.

This event included an early release of the circulating activity with washoff of plated out material from the HPB due to the over-pressurization followed by a subsequent long term release due to the core heatup from the fuel and graphite and then from the HPB.

After selection of the reactor configurations and accident scenarios, the team developed estimates for the release fractions and attenuations factors for the specific configuration and accident scenario presented in Section A-4. These factors and the initial core inventory (Section 2.3) are used as inputs to the dose evaluation model following the formulas presented in A-2.

The development of the release and attenuation factors included consideration of past HTGR analyses and experiments including:

- Barnes, C.M. and J.D. Hunn, "Fabrication and Comparison of Fuels for Advanced Gas Reactor Tests," $5^{\text {th }}$ International Topical Meeting on High Temperature Reactor Technology (HTR-2010) Prague Czech Republic, Oct 18-20, 2010.

- Bullock, R.E., "Fission Product Release during Postirradiation Annealing of Several Types of Coated Particle Fuels," J. Nuclear Mater. Vol 125, 304 (1984).

- DOE-HTGR-86024, Rev. 13, Preliminary Safety Information Document for the Standard MHTGR, September 1992.

- DOE-HTGR-86-011, Rev. 3, Vol. 1 \&2, Probabilistic Risk Assessment for the Standard Modular High Temperature Gas-Cooled Reactor .

- DOE-HTGR-88552, COMEDIE BD-1 Test Evaluation Report, W. Medwid and A. Gillespie, General Atomics, 1993.

- DOE-HTGR-90229, Rev. 0, 450 MWt MHTGR Safety Consequence Assessment, September 1991.

- DOE- GT-MHR-100230, GT-MHR Preliminary Safety Assessment Report, September 1994. 
- Grover, S.B. et al., "Mission and Status of the First Two Next Generation Nuclear Plant Fuel Irradiation Experiments in the Advanced Test Reactor," Proceedings of the $18^{\text {th }}$ International Conference of Nuclear Engineering, Xian China, May 17-20, 2010.

- Hanson, D.L., "NGNP Contamination Control Study,” GA Document 911117, Rev. 0, General Atomics, April 2008.

- Hanson, D.L., "Reconciliation of NGNP DDNs with NRC PIRTs," GA Document PC-000570, Rev. 0, General Atomics, September 2008.

- Hanson, D.L., "Logic for Deriving Fuel Quality Specifications," GA Document PC-00049810, Rev. 0, General Atomics, March 2001.

- Hanson, D. L., "Technical Basis for NGNP Fuel Performance and Quality Requirements," GA Document 911168, Rev. 0, General Atomics, September 2009.

- $\quad$ NGNP-IN-RPT-001, NGNP and Hydrogen Production Preconceptual Design Report, May 2007.

- $\quad$ NGNP-NHS 50-CC, NGNP and Hydrogen Production Preconceptual Design Study, May 2008.

- $\quad$ NGNP-PLD-GEN-RPT-N-0007, NGNP: Plant Level Assessments Leading to Fission Product Retention Allocations, October 2009.

- Minato K., et al., "Fission Product Release Behavior of Individual Coated Fuel Particles for High Temperature Gas Cooled Reactors," Nuclear Technology, Vol 131, 36 (2000).

- Petti, D.A., et al., "Key differences in the Fabrication, Irradiation, and Safety Testing of U.S. and German TRISO-coated Particle Fuel and their Implications on Fuel Performance," INL/EXT-0200300, April 2002.

- $\quad$ TECDOC-978, Fuel Performance and Fission Product Behavior in Gas Cooled Reactors, International Atomic Energy Agency, November 1997. 


\section{A-1. Agenda}

\section{Idaho National Laboratory}

\section{Expert Panel Scoping Analysis - Offsite Dose}

\section{Analysis}

September 7-8, 2011

AmeriTel Inn, 645 Lindsay Boulevard, Idaho Falls, Idaho

Attire: Business Casual

\section{Wednesday, September 7}

8:00 Meeting Kickoff

David Petti

Tom Hicks

8:15 Confirm list of accidents to be evaluated - list previously distributed to panel for comment

Pete Lowry

10:00 Break

10:15 Establish the initial set of key parameters (including assumed design and environmental conditions) for selected accidents to include core size, radionuclides to be modeled, initial inventory assumptions (core circulating, plateout and dust)

$11: 30$ Lunch

No host

1:00 Continue discussion of initial set of key parameters and algorithm to be used

Pete Lowry

2:00 Develop input assumptions for the performance of each of the barriers presented in the MST paper

Pete Lowry

David Petti

3:00 Break

3:15 Continue discussion of input assumptions for barrier performance

David Petti

5:00 Wrap up and adjourn

David Petti

Tom Hicks 


\section{Thursday, September 8}

8:00 Assess the impacts of applicable parameters for each event, e.g., release duration (break size), release point-elevation, and impacts of

David Petti dust, air and water (chemical attack) on the barrier performance

10:00 Break

10:15 Continue discussion of impacts of applicable parameters

David Petti

11:30 Lunch

No host

1:00 Development of uncertainty ranges for each of the key parameters

David Petti

3:00 Break

3:15 Continue discussion of uncertainty ranges

David Petti

4:00 Wrap up and adjourn

David Petti

Tom Hicks 


\section{Summary of Proposed "DBA" Events to be Considered}

\begin{tabular}{|c|c|}
\hline Event Category & Summary of Event (Reference) \\
\hline $\begin{array}{l}\text { Loss of forced } \\
\text { circulation with } \\
\text { depressurization }\end{array}$ & $\begin{array}{l}\text { Large Break (AREVA 7.2.1) } \\
\text { Primary System is voided within minutes at a maximum depressurization rate of } 0.8 \mathrm{bar} / \mathrm{s} \text { [11 } \\
\text { psi/s]. } \\
\text { SCRAM occurs after } ~ 10 \mathrm{sec} \text {, pressure drops from } 60 \mathrm{BAR} \text { [ } 870 \mathrm{psi} \text {,] to } 55 \mathrm{BAR} \text { [ } 800 \mathrm{psi}] \text {. } \\
\text { Response of internal pressure equalization system } 70 \mathrm{sec} \text {, pressure drops to } 25 \mathrm{BAR} \text { [362 psi]. } \\
\text { Assumed break occurs in the outlet line to the helium purification system at the steam } \\
\text { generator pressure vessel. } \\
\text { Desorption leads to the release from the primary system of approximately } 3 \text { times the steady- } \\
\text { state coolant activity until pressure equalization is reached. } \\
\text { Primary system surface activity, design values for } 32 \text { equivalent-power years. } 1 \mathrm{~kg} \text { of dust } \\
\text { taken up by the primary coolant from dead flow zones during blowdown and is subsequently } \\
\text { released from the primary system. For long-lived radionuclides, the specific activity of this } \\
\text { dust is equivalent to the specific activity of the graphite on the surfaces of the fuel elements. }\end{array}$ \\
\hline $\begin{array}{l}\text { Loss of forced } \\
\text { circulation with } \\
\text { depressurization }\end{array}$ & $\begin{array}{l}\text { Pressure Relief with Subsequent Core Heat-up (AREVA 7.2.2) } \\
\text { Reactor is depressurized while in long-term steady-state operation with a cold gas temperature } \\
\text { of } 280^{\circ} \mathrm{C} \text { and at } 105 \% \text { of nominal power. } \\
\text { Peak core temperature of } \sim 1522^{\circ} \mathrm{C} \text { is reached after } 30 \mathrm{hrs} \text {. } \\
\text { The max heat flux at the cavity cooler is } \sim 720 \mathrm{~kW} \text {. }\end{array}$ \\
\hline $\begin{array}{l}\text { Rupture with air } \\
\text { ingress }\end{array}$ & $\begin{array}{l}\text { Primary Coolant Leak without HTS and SCS Cooling (PSID 15.12) } \\
\text { Leak, } 0.32 \mathrm{sq} \mathrm{cm} \text { area, near the top of the reactor vessel. } \\
\text { Primary coolant pressure decreases below about } 2.93 \mathrm{Mpa}[425 \mathrm{psi}] \text { at } 5300 \text { seconds. At the } \\
\text { time of HTS and SCS failure pressure conditions of } 0.155 \mathrm{Mpa}[22 \mathrm{psi}] \text { exist. } \\
\text { Maximum fuel temperature reaches a peak of } 1533^{\circ} \mathrm{C} \text { approximately } 120 \text { hours after the } \\
\text { initiating event. } \\
\text { During hydrostatic displacement } 172 \mathrm{~kg} \text { of air enters and } 0.005 \text { percent of graphite mass in the } \\
\text { core is oxidized. Complete consumption of the oxygen in the air is assumed. During thermal } \\
\text { contraction } 95 \mathrm{~kg} \text { of additional air is ingressed, oxidizing another } 0.003 \text { percent of graphite } \\
\text { mass in the core. } \\
\text { Fission products are released from two sources: the primary coolant circulating activity and the } \\
\text { fuel body activity. }\end{array}$ \\
\hline
\end{tabular}




\begin{tabular}{|c|c|}
\hline Event Category & Summary of Event (Reference) \\
\hline $\begin{array}{l}\text { Water Ingress } \\
\text { Events }\end{array}$ & $\begin{array}{l}\text { Steam Generator Tube Ruptures (AREVA 7.2.4, PSID 15.7-15.10) } \\
\text { Leak rates range from: } 0.05 \mathrm{~kg} / \mathrm{s} \text { to } 5.7 \mathrm{~kg} / \mathrm{s} \text { (can be up to } 27.2 \mathrm{~kg} / \mathrm{s} \text { within the first few } \\
\text { seconds). } \\
\text { Total inleakage ranges from: } 18.1 \mathrm{~kg} \text { to } 841 \mathrm{~kg} \text {. } \\
\text { Burnoff for bottom reflector blocks range from: } 8 \mathrm{E}-05 \text { to } 8 \mathrm{E}-04 \text { weight fraction. } \\
\text { Burnoff for hot channel ranges from: } 3 \mathrm{E}-04 \text { to } 6.1 \mathrm{E}-03 \text {. } \\
\text { Steam reaction with fuel and hot graphite structure forms a water gas fraction around } 9 \% \text {, } \\
\text { which is not flammable in any mixture with air. } \\
\text { Mechanisms for release: hydrolysis of UCO particles having failed coatings, liberation of } \\
\text { sorbed fission products in the bulk moderator graphite which is oxidized, diffusion (due to } \\
\text { elevated temperatures) of fission products out of fuel particles that have failed, or steam- } \\
\text { induced vaporization and recirculation of fission products plated out on metallic surfaces. }\end{array}$ \\
\hline Reactivity events & $\begin{array}{l}\text { Control Rod Withdrawal without HTS and SCS cooling (PSID 15.5) } \\
\text { Peak fuel temperature } 1394^{\circ} \mathrm{C} \text {. } \\
\text { Max core temperature peaks at approximately } 1307^{\circ} \mathrm{C} \text {. } \\
\text { System pressure peaks at } 1016 \text { psia. } \\
\text { The gaseous fission products, including halogens, are released directly to the reactor vessel } \\
\text { without significant attenuation by the fuel rod matrix graphite and fuel element graphite. } \\
\text { Metallic fission products released from the fuel particles are delayed by adsorption and slow } \\
\text { diffusion through the fuel rod matrix and the fuel element graphite. This accident will result in } \\
\text { the release of some fission products to the primary coolant from failed fuel. } \\
\text { The primary coolant remains pressurized and the primary coolant boundary integrity } \\
\text { remains intact, there is no release from the vessel, no release from the Reactor Building, } \\
\text { and no offsite dose. }\end{array}$ \\
\hline $\begin{array}{l}\text { Loss of forced } \\
\text { circulation - } \\
\text { Pressurized }\end{array}$ & $\begin{array}{l}\text { Control Rod Withdrawal without HTS and SCS cooling (PSID 15.5) } \\
\text { Peak fuel temperature } 1394^{\circ} \mathrm{C} \text {. } \\
\text { Max core temperature peaks at approximately } 1307^{\circ} \mathrm{C} \text {. } \\
\text { System pressure peaks at } 1016 \text { psia. } \\
\text { The gaseous fission products, including halogens, are released directly to the reactor vessel } \\
\text { without significant attenuation by the fuel rod matrix graphite and fuel element graphite. } \\
\text { Metallic fission products released from the fuel particles are delayed by adsorption and slow } \\
\text { diffusion through the fuel rod matrix and the fuel element graphite. This accident will result in } \\
\text { the release of some fission products to the primary coolant from failed fuel. } \\
\text { The primary coolant remains pressurized and the primary coolant boundary integrity } \\
\text { remains intact, there is no release from the vessel, no release from the Reactor Building, } \\
\text { and no offsite dose. }\end{array}$ \\
\hline
\end{tabular}


Initial radionuclide inventory and other conditions to be established for all events.

Core Inventory (Fuel):

Inventory sorbed in Graphite (Core)

Circulating Inventory (HPB)

Plateout (assumed on HPB piping)

Inventory in Dust (HPB)

Review of Radionuclides to be modeled. (Does Ingestion and Contamination drive consideration of additional nuclides?)

\section{Overview of project scope and purpose:}

As an output of recent discussions on NGNP R\&D needs, including the need for in-pile loop testing, it was concluded that an expert review process be used to establish defensible and target values for the radionuclide transfer factors for the input assumptions to develop the mechanistic source term used in the simplified parametric dose analysis model. The results of this modeling will assist in determining where the NGNP Project is in establishing parameters that will meet Project objectives related to protection of public health and safety. Key principals of these objectives believed to significantly impact the need for R\&D information include:

- Development of a HTGR safety basis that protects the health and safety of the public and the environment with the objective that under no projected accident condition are evacuation or sheltering required nor will the food and water supplies be adversely impacted by radionuclide contamination.

- Meeting EPA PAGs at the Plant EAB. This includes a goal of meeting the Ingestion Pathway PAG (if reasonably achievable).

- Quantification of the risk of contamination and demonstration of the ability to reduce this risk via measures (including prevention and mitigation) acceptable to both the end user and reactor owner/operator. (A concern of potential end users is that an accident in the HTGR plant would contaminate the co-located facility rendering it indefinitely un-usable.)

As more analysis and testing are completed under the NGNP R\&D Program these values will be revised as necessary.

As a separate subgroup to this panel, a review of the approach for modeling radionuclide transport outside of RB will be included.

As a follow-on activity, the expert panel will review the results of the calculations supporting the assessment the dose and contamination levels associated with above. 


\section{A-2. Formulas Used in Dose Evaluation Model}

Using these inputs and the 50\% and 95\% upper bound barrier performance characteristics developed in this appendix, the mechanistic source terms (releases) are calculated consistent with the simplified equations presented herein:

where:

$D F$ : decontamination factor; (attenuation factor)

FP: Fission Product

$D R$ : diffusive release through coating;

$I S F$ : in-service failure;

$G$ : graphite;

$K$ : fuel kernel;

$H M C$ : heavy metal contamination;

LO: Lift Off -HPB;

$i$ : radionuclide index;

$L T$ : long term;

$I F$ : incremental failure under accident;

$H P B$ : helium pressure boundary;

Inv: Inventory;

$R B$ : reactor building;

$S T$ : short term.

\section{Normal Operations Release}

$$
=\text { Normal Ops HMC + Normal Ops SiC Defect + Normal Ops In-Service Failure }
$$

\section{Normal Operations HMC}

$$
=\operatorname{Inv}_{i} \cdot \frac{F P_{i, H M C}}{D F_{i, H M C} \cdot D F_{i, G}}
$$

Normal Operations SiC

$$
=\operatorname{Inv} v_{i} \cdot \frac{F P_{i, I S F}}{D F_{i, K} \cdot D F_{i, G}}
$$

Normal Operations In-Service Failure

$$
=\operatorname{Inv} v_{i} \cdot \frac{1}{D F_{i, K} \cdot D F_{i, D R} \cdot D F_{i, G}}
$$

\section{Release to Environment Short Term}

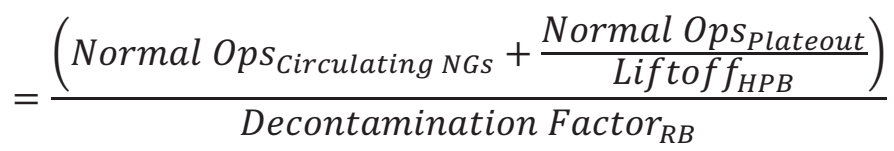

Release to Environment Long Term

$$
\begin{gathered}
=\frac{\text { Accident Release from Fuel to HPB }+ \text { Accident Release from Graphite }}{\text { Decontamination Factor } \text { frPB }_{\boldsymbol{H} \text {. }} \times \text { Decontamination Factor }_{\boldsymbol{R} B}} \\
=\frac{\left(I n v_{i} \cdot\left(\frac{F P_{i, L T, H M C}}{D F_{i, L T, H M C}}+\frac{F P_{i, L T, I S F}}{D F_{i, L T, N I N T}}+\frac{F P_{i, L T, I F}}{D F_{i, L T, N I N T}}+\frac{1}{D F_{i, L T, I N T}}\right) \cdot D F_{i, L T, G}{ }^{-1}+\frac{\text { Normal Ops Graphite }}{D F_{i, L T, G}}\right)}{\left(D F_{L T, H P B} \times D F_{L T, R B}\right)}
\end{gathered}
$$




\section{A-3. Inventory Assumptions}

The following inventory assumptions and inputs were used to develop the source term.

\begin{tabular}{|c|c|c|c|c|}
\hline $\begin{array}{c}\text { Fission Product } \\
\text { Class }\end{array}$ & $\begin{array}{c}\text { Characteristic } \\
\text { Nuclide }\end{array}$ & Half-Life Days & $\begin{array}{c}\text { Decay } \\
\text { Constant }^{\mathrm{a}}\end{array}$ & $\begin{array}{l}\text { Inventory- } \\
600 \mathrm{MW}^{\mathrm{b}, \mathrm{c}}\end{array}$ \\
\hline \multirow{3}{*}{ Noble Gases } & Xe-133 & 5.29 & $1.52 \mathrm{E}-06$ & $3.63 \mathrm{E}+07$ \\
\hline & $\mathrm{Kr}-85$ & 3916.45 & $2.05 \mathrm{E}-09$ & $1.90 \mathrm{E}+05$ \\
\hline & $\mathrm{Kr}-88$ & 0.116667 & $6.88 \mathrm{E}-05$ & $1.85 \mathrm{E}+07$ \\
\hline \multirow{3}{*}{$\mathrm{I}, \mathrm{Br}, \mathrm{Te}, \mathrm{Se}$} & $\mathrm{I}-131$ & 8.04 & $9.98 \mathrm{E}-07$ & $2.00 \mathrm{E}+07$ \\
\hline & $\mathrm{I}-133$ & 0.866667 & $9.26 \mathrm{E}-06$ & $3.60 \mathrm{E}+07$ \\
\hline & Te-132 & 3.25 & $2.47 \mathrm{E}-06$ & $2.71 \mathrm{E}+07$ \\
\hline \multirow{2}{*}{$\mathrm{Cs}, \mathrm{Rb}$} & Cs-137 & 10986.5 & $7.30 \mathrm{E}-10$ & $1.69 \mathrm{E}+06$ \\
\hline & Cs-134 & 751.9 & $1.07 \mathrm{E}-08$ & $1.90 \mathrm{E}+06$ \\
\hline $\mathrm{Sr}, \mathrm{Ba}, \mathrm{Eu}$ & Sr-90 & 10585 & $7.58 \mathrm{E}-10$ & $1.69 \mathrm{E}+06$ \\
\hline \multirow{2}{*}{$\mathrm{Ag}, \mathrm{Pd}$} & $\mathrm{Ag}-110 \mathrm{~m}$ & 252 & $3.18 \mathrm{E}-08$ & $2.81 \mathrm{E}+04$ \\
\hline & Ag-111 & 7.47 & $1.07 \mathrm{E}-06$ & $2.96 \mathrm{E}+06$ \\
\hline $\mathrm{Sb}$ & $\mathrm{Sb}-125$ & 996.45 & $8.05 \mathrm{E}-09$ & $2.35 \mathrm{E}+05$ \\
\hline Mo, Ru, Rh, Tc & Ru-103 & 39.6 & $2.03 \mathrm{E}-07$ & $3.61 \mathrm{E}+07$ \\
\hline \multirow{2}{*}{$\mathrm{La}, \mathrm{Ce}$ groups } & $\mathrm{Ce}-144$ & 103660 & $7.74 \mathrm{E}-11$ & $2.33 \mathrm{E}+07$ \\
\hline & La-140 & 1.675 & $4.79 \mathrm{E}-06$ & $3.27 \mathrm{E}+07$ \\
\hline $\mathrm{Pu}$, actinides & $\mathrm{Pu}-239$ & 8800150 & $9.12 \mathrm{E}-13$ & $4.66 \mathrm{E}+03$ \\
\hline
\end{tabular}

a. Decay constant $(\lambda)$ from http://users.ictp.it/ pub off/lectures/lns020/Nichols/Nichols.pdf

b. Inventory based on 91117 Rev 0 NGNP Contamination Control Study, General Atomics, 2008

c. Plutonium inventory from General Atomics (350 MW). 


\section{A-4. Release Fractions And Attenuation Factors}

\section{A-4.1 $600 \mathrm{MW}(\mathrm{t})$ Prismatic $700^{\circ} \mathrm{C}$}

\section{A-4.1.1 Normal Operations}

Table A-1. $600 \mathrm{MW}(\mathrm{t})$ prismatic $700^{\circ} \mathrm{C}$ ROT_normal operations - release fractions and attenuation factors.

\begin{tabular}{|c|c|c|c|c|c|c|c|c|c|c|c|c|c|c|}
\hline \multirow{3}{*}{ Nuclide } & \multicolumn{6}{|c|}{ Sources of Fission Product Release } & \multicolumn{8}{|c|}{ Barriers to Fission Product Release (Attenuation Factors) } \\
\hline & \multicolumn{2}{|c|}{$\begin{array}{c}\text { Fract. HM } \\
\text { Contamination }\end{array}$} & \multicolumn{2}{|c|}{$\begin{array}{l}\text { Fraction } \mathrm{SiC} \\
\text { Defects }\end{array}$} & \multicolumn{2}{|c|}{ In-Service Failure } & \multicolumn{2}{|c|}{$\begin{array}{l}\text { Heavy Metal } \\
\text { Contamination }\end{array}$} & \multicolumn{2}{|c|}{ Kernel } & \multicolumn{2}{|c|}{$\begin{array}{l}\text { Diffusive Release } \\
\text { thru coating }\end{array}$} & \multicolumn{2}{|c|}{ Graphite } \\
\hline & $50 \%$ & $95 \%$ & $50 \%$ & $95 \%$ & $50 \%$ & $95 \%$ & $50 \%$ & $95 \%$ & $50 \%$ & $95 \%$ & $50 \%$ & $95 \%$ & $50 \%$ & $95 \%$ \\
\hline $\mathrm{Xe}-133$ & $1 \mathrm{E}-05$ & $2 \mathrm{E}-05$ & NA & NA & $7 \mathrm{E}-06$ & $2 \mathrm{E}-05$ & 10 & 3 & 50 & 17 & $1 \mathrm{E}+08$ & $1 \mathrm{E}+07$ & 1 & 1 \\
\hline $\mathrm{Kr}-85$ & $1 \mathrm{E}-05$ & $2 \mathrm{E}-05$ & NA & NA & $7 \mathrm{E}-06$ & $2 \mathrm{E}-05$ & 10 & 3 & 50 & 17 & $1 \mathrm{E}+08$ & $1 \mathrm{E}+07$ & 1 & 1 \\
\hline $\mathrm{Kr}-88$ & $1 \mathrm{E}-05$ & $2 \mathrm{E}-05$ & NA & NA & $7 \mathrm{E}-06$ & $2 \mathrm{E}-05$ & 10 & 3 & 50 & 17 & $1 \mathrm{E}+08$ & $1 \mathrm{E}+07$ & 1 & 1 \\
\hline I-131 & $1 \mathrm{E}-05$ & $2 \mathrm{E}-05$ & NA & NA & $7 \mathrm{E}-06$ & $2 \mathrm{E}-05$ & 10 & 3 & 50 & 17 & $1 \mathrm{E}+08$ & $1 E+07$ & 1 & 1 \\
\hline I-133 & $1 \mathrm{E}-05$ & $2 \mathrm{E}-05$ & NA & NA & $7 \mathrm{E}-06$ & $2 \mathrm{E}-05$ & 10 & 3 & 50 & 17 & $1 \mathrm{E}+08$ & $1 \mathrm{E}+07$ & 1 & 1 \\
\hline Te-132 & $1 \mathrm{E}-05$ & $2 \mathrm{E}-05$ & NA & NA & $7 \mathrm{E}-06$ & $2 \mathrm{E}-05$ & 10 & 3 & 50 & 17 & $1 \mathrm{E}+08$ & $1 \mathrm{E}+07$ & 1 & 1 \\
\hline Cs-137 & $1 \mathrm{E}-05$ & $2 \mathrm{E}-05$ & $1 \mathrm{E}-05$ & $3 \mathrm{E}-05$ & $7 \mathrm{E}-06$ & $2 \mathrm{E}-05$ & 1 & 1 & 3 & 1 & $1 \mathrm{E}+08$ & $1 \mathrm{E}+06$ & 5 & 2 \\
\hline Cs-134 & $1 \mathrm{E}-05$ & $2 \mathrm{E}-05$ & $1 \mathrm{E}-05$ & $3 \mathrm{E}-05$ & 7E-06 & $2 \mathrm{E}-05$ & 1 & 1 & 3 & 1 & $1 \mathrm{E}+08$ & $1 \mathrm{E}+06$ & 5 & 2 \\
\hline Sr-90 & $1 \mathrm{E}-05$ & $2 \mathrm{E}-05$ & $1 \mathrm{E}-05$ & $3 \mathrm{E}-05$ & $7 \mathrm{E}-06$ & $2 \mathrm{E}-05$ & 1 & 1 & 50 & 20 & 1000 & 200 & 1000 & 300 \\
\hline $\mathrm{Ag}-110 \mathrm{~m}$ & $1 \mathrm{E}-05$ & $2 \mathrm{E}-05$ & $1 \mathrm{E}-05$ & $3 \mathrm{E}-05$ & $7 \mathrm{E}-06$ & $2 \mathrm{E}-05$ & 1 & 1 & 2 & 1 & 500 & 100 & 2 & 1 \\
\hline Ag-111 & $1 \mathrm{E}-05$ & $2 \mathrm{E}-05$ & $1 \mathrm{E}-05$ & $3 \mathrm{E}-05$ & 7E-06 & $2 \mathrm{E}-05$ & 1 & 1 & 2 & 1 & 500 & 100 & 2 & 1 \\
\hline $\mathrm{Sb}-125$ & 1E-05 & $2 \mathrm{E}-05$ & $1 \mathrm{E}-05$ & $3 \mathrm{E}-05$ & $7 \mathrm{E}-06$ & $2 \mathrm{E}-05$ & 1 & 1 & 2 & 1 & $1 \mathrm{E}+08$ & $1 E+06$ & 20 & 2 \\
\hline Ru-103 & $1 \mathrm{E}-05$ & $2 \mathrm{E}-05$ & $1 \mathrm{E}-05$ & $3 \mathrm{E}-05$ & $7 \mathrm{E}-06$ & $2 \mathrm{E}-05$ & 1 & 1 & 500 & 30 & $1 \mathrm{E}+08$ & $1 E+07$ & 1000 & 300 \\
\hline Ce-144 & $1 \mathrm{E}-05$ & $2 \mathrm{E}-05$ & $1 \mathrm{E}-05$ & $3 \mathrm{E}-05$ & 7E-06 & $2 \mathrm{E}-05$ & 1 & 1 & 500 & 30 & $1 \mathrm{E}+08$ & $1 \mathrm{E}+07$ & 1000 & 300 \\
\hline La-140 & $1 \mathrm{E}-05$ & $2 \mathrm{E}-05$ & $1 \mathrm{E}-05$ & $3 \mathrm{E}-05$ & $7 \mathrm{E}-06$ & $2 \mathrm{E}-05$ & 1 & 1 & 500 & 30 & $1 \mathrm{E}+08$ & $1 E+07$ & 1000 & 300 \\
\hline $\mathrm{Pu}-239$ & $1 \mathrm{E}-05$ & $2 \mathrm{E}-05$ & $1 \mathrm{E}-05$ & $3 \mathrm{E}-05$ & $7 \mathrm{E}-06$ & $2 \mathrm{E}-05$ & 1 & 1 & 1000 & 100 & $1 \mathrm{E}+08$ & $1 \mathrm{E}+07$ & $1 \mathrm{E}+04$ & 1000 \\
\hline
\end{tabular}


A-4.1.2 Accident Scenario: Break in Helium Pressure Boundary

Table A-2. $600 \mathrm{MW}(\mathrm{t})$ prismatic $700^{\circ} \mathrm{C}$ ROT — break in HPB — short term attenuation factors.

\begin{tabular}{|c|c|c|c|c|}
\hline \multirow{3}{*}{ Nuclide } & \multicolumn{4}{|c|}{$\begin{array}{c}\text { Short Term Barriers to Fission Product Release } \\
\text { (Attenuation Factors) }\end{array}$} \\
\hline & \multicolumn{2}{|c|}{ Accident - HPB } & \multicolumn{2}{|c|}{$\begin{array}{l}\text { Accident }- \text { Reactor } \\
\text { Building }\end{array}$} \\
\hline & DF $50 \%$ & DF $95 \%$ & DF $50 \%$ & DF $95 \%$ \\
\hline Xe-133 & 1 & 1 & 1 & 1 \\
\hline $\mathrm{Kr}-85$ & 1 & 1 & 1 & 1 \\
\hline $\mathrm{Kr}-88$ & 1 & 1 & 1 & 1 \\
\hline I-131 & 200 & 20 & 2 & 1 \\
\hline I-133 & 200 & 20 & 2 & 1 \\
\hline Te-132 & 200 & 20 & 2 & 1 \\
\hline Cs-137 & 200 & 20 & 2 & 1 \\
\hline Cs-134 & 200 & 20 & 2 & 1 \\
\hline Sr-90 & 200 & 20 & 2 & 1 \\
\hline $\mathrm{Ag}-110 \mathrm{~m}$ & 200 & 20 & 2 & 1 \\
\hline Ag-111 & 200 & 20 & 2 & 1 \\
\hline Sb-125 & 200 & 20 & 2 & 1 \\
\hline $\mathrm{Ru}-103$ & 200 & 20 & 2 & 1 \\
\hline Ce-144 & 200 & 20 & 2 & 1 \\
\hline La-140 & 200 & 20 & 2 & 1 \\
\hline $\mathrm{Pu}-239$ & 200 & 20 & 2 & 1 \\
\hline
\end{tabular}


Table A-3. $600 \mathrm{MW}(\mathrm{t})$ prismatic $700^{\circ} \mathrm{C}$ ROT- break in HPB-long term release fractions and attenuation factors.

\begin{tabular}{|c|c|c|c|c|c|c|c|c|c|c|c|c|c|c|c|c|c|c|}
\hline \multirow{3}{*}{ Nuclide } & \multicolumn{6}{|c|}{ Sources of Fission Product Release } & \multicolumn{12}{|c|}{ Barriers to Fission Product Release (Attenuation Factors } \\
\hline & \multicolumn{2}{|c|}{$\begin{array}{c}\text { Fract. HM } \\
\text { Contamination }\end{array}$} & \multicolumn{2}{|c|}{$\begin{array}{l}\text { Non-Intact (In- } \\
\text { service failure) }\end{array}$} & \multicolumn{2}{|c|}{$\begin{array}{c}\text { Incremental } \\
\text { Failure - } \\
\text { Accidents }\end{array}$} & \multicolumn{2}{|c|}{$\begin{array}{c}\text { HM } \\
\text { Accident } \\
\text { Release }\end{array}$} & \multicolumn{2}{|c|}{$\begin{array}{l}\text { Non-intact } \\
\text { Accident } \\
\text { Release }\end{array}$} & \multicolumn{2}{|c|}{$\begin{array}{l}\text { Intact Accident } \\
\text { Release }\end{array}$} & \multicolumn{2}{|c|}{$\begin{array}{l}\text { Accident - } \\
\text { Graphite }\end{array}$} & \multicolumn{2}{|c|}{$\begin{array}{l}\text { Accident - } \\
\text { HPB }\end{array}$} & \multicolumn{2}{|c|}{$\begin{array}{l}\text { Accident - } \\
\text { Reactor } \\
\text { Building }\end{array}$} \\
\hline & $50 \%$ & $95 \%$ & $50 \%$ & $95 \%$ & $50 \%$ & $95 \%$ & $\begin{array}{c}\mathrm{DF} \\
50 \%\end{array}$ & $\begin{array}{c}\mathrm{DF} \\
95 \%\end{array}$ & $\begin{array}{c}\mathrm{DF} \\
50 \%\end{array}$ & $\begin{array}{c}\mathrm{DF} \\
95 \%\end{array}$ & DF $50 \%$ & DF 95\% & $\begin{array}{c}\mathrm{DF} \\
50 \%\end{array}$ & $\begin{array}{c}\mathrm{DF} \\
95 \%\end{array}$ & $\begin{array}{c}\mathrm{DF} \\
50 \%\end{array}$ & $\begin{array}{c}\mathrm{DF} \\
95 \%\end{array}$ & $\begin{array}{c}\mathrm{DF} \\
50 \%\end{array}$ & $\begin{array}{l}\text { DF } \\
95 \%\end{array}$ \\
\hline $\mathrm{Xe}-133$ & $1 \mathrm{E}-05$ & $2 \mathrm{E}-05$ & $7 \mathrm{E}-06$ & $2 \mathrm{E}-05$ & $3 \mathrm{E}-05$ & $8 \mathrm{E}-05$ & 2 & 1 & 10 & 5 & $1 \mathrm{E}+07$ & $2 \mathrm{E}+06$ & 1 & 1 & 5 & 2 & 1 & 1 \\
\hline $\mathrm{Kr}-85$ & $1 \mathrm{E}-05$ & $2 \mathrm{E}-05$ & $7 \mathrm{E}-06$ & $2 \mathrm{E}-05$ & $3 \mathrm{E}-05$ & $8 \mathrm{E}-05$ & 2 & 1 & 10 & 5 & $1 \mathrm{E}+07$ & $2 \mathrm{E}+06$ & 1 & 1 & 5 & 2 & 1 & 1 \\
\hline $\mathrm{Kr}-88$ & $1 \mathrm{E}-05$ & $2 \mathrm{E}-05$ & 7E-06 & $2 \mathrm{E}-05$ & $3 \mathrm{E}-05$ & $8 \mathrm{E}-05$ & 2 & 1 & 10 & 5 & $1 \mathrm{E}+07$ & $2 \mathrm{E}+06$ & 1 & 1 & 5 & 2 & 1 & 1 \\
\hline I-131 & $1 \mathrm{E}-05$ & $2 \mathrm{E}-05$ & $7 \mathrm{E}-06$ & $2 \mathrm{E}-05$ & $3 \mathrm{E}-05$ & $8 \mathrm{E}-05$ & 2 & 1 & 10 & 5 & $1 \mathrm{E}+07$ & $2 \mathrm{E}+06$ & 1 & 1 & 5 & 2 & 10 & 2 \\
\hline I-133 & $1 \mathrm{E}-05$ & $2 \mathrm{E}-05$ & $7 \mathrm{E}-06$ & $2 \mathrm{E}-05$ & $3 \mathrm{E}-05$ & $8 \mathrm{E}-05$ & 2 & 1 & 10 & 5 & $1 \mathrm{E}+07$ & $2 \mathrm{E}+06$ & 1 & 1 & 5 & 2 & 10 & 2 \\
\hline Te-132 & $1 \mathrm{E}-05$ & $2 \mathrm{E}-05$ & $7 \mathrm{E}-06$ & $2 \mathrm{E}-05$ & $3 \mathrm{E}-05$ & $8 \mathrm{E}-05$ & 2 & 1 & 10 & 5 & $1 \mathrm{E}+07$ & $2 \mathrm{E}+06$ & 1 & 1 & 5 & 2 & 10 & 2 \\
\hline Cs-137 & $1 \mathrm{E}-05$ & $2 \mathrm{E}-05$ & $1.7 \mathrm{E}-05$ & $5 \mathrm{E}-05$ & $3 \mathrm{E}-05$ & $8 \mathrm{E}-05$ & 1 & 1 & 1 & 1 & $1 \mathrm{E}+07$ & $2 \mathrm{E}+06$ & 10 & 3 & 10 & 3 & 10 & 2 \\
\hline Cs-134 & $1 \mathrm{E}-05$ & $2 \mathrm{E}-05$ & $1.7 \mathrm{E}-05$ & $5 \mathrm{E}-05$ & $3 \mathrm{E}-05$ & $8 \mathrm{E}-05$ & 1 & 1 & 1 & 1 & $1 \mathrm{E}+07$ & $2 \mathrm{E}+06$ & 10 & 3 & 10 & 3 & 10 & 2 \\
\hline Sr-90 & $1 \mathrm{E}-05$ & $2 \mathrm{E}-05$ & $1.7 \mathrm{E}-05$ & $5 \mathrm{E}-05$ & $3 \mathrm{E}-05$ & $8 \mathrm{E}-05$ & 1 & 1 & 1 & 1 & $1 \mathrm{E}+06$ & $2 \mathrm{E}+05$ & 100 & 30 & 10 & 3 & 10 & 2 \\
\hline Ag-110m & $1 \mathrm{E}-05$ & $2 \mathrm{E}-05$ & $1.7 \mathrm{E}-05$ & $5 \mathrm{E}-05$ & $3 \mathrm{E}-05$ & $8 \mathrm{E}-05$ & 1 & 1 & 1 & 1 & $5 \mathrm{E}+02$ & $1 \mathrm{E}+02$ & 1 & 1 & 10 & 3 & 10 & 2 \\
\hline Ag-111 & $1 \mathrm{E}-05$ & $2 \mathrm{E}-05$ & $1.7 \mathrm{E}-05$ & $5 \mathrm{E}-05$ & $3 \mathrm{E}-05$ & $8 \mathrm{E}-05$ & 1 & 1 & 1 & 1 & $5 \mathrm{E}+02$ & $1 \mathrm{E}+02$ & 1 & 1 & 10 & 3 & 10 & 2 \\
\hline Sb-125 & $1 \mathrm{E}-05$ & $2 \mathrm{E}-05$ & $1.7 \mathrm{E}-05$ & $5 \mathrm{E}-05$ & $3 \mathrm{E}-05$ & $8 \mathrm{E}-05$ & 1 & 1 & 1 & 1 & $1 \mathrm{E}+06$ & $2 \mathrm{E}+05$ & 100 & 30 & 10 & 3 & 10 & 2 \\
\hline Ru-103 & $1 \mathrm{E}-05$ & $2 \mathrm{E}-05$ & $1.7 \mathrm{E}-05$ & $5 \mathrm{E}-05$ & $3 \mathrm{E}-05$ & $8 \mathrm{E}-05$ & 1 & 1 & 100 & 50 & $1 \mathrm{E}+07$ & $2 \mathrm{E}+06$ & 10 & 3 & 10 & 3 & 10 & 2 \\
\hline Ce-144 & $1 \mathrm{E}-05$ & $2 \mathrm{E}-05$ & $1.7 \mathrm{E}-05$ & $5 \mathrm{E}-05$ & $3 \mathrm{E}-05$ & $8 \mathrm{E}-05$ & 1 & 1 & 100 & 50 & $1 \mathrm{E}+07$ & $2 \mathrm{E}+06$ & 100 & 30 & 10 & 3 & 10 & 2 \\
\hline La-140 & $1 \mathrm{E}-05$ & $2 \mathrm{E}-05$ & $1.7 \mathrm{E}-05$ & $5 \mathrm{E}-05$ & $3 \mathrm{E}-05$ & $8 \mathrm{E}-05$ & 1 & 1 & 100 & 50 & $1 \mathrm{E}+07$ & $2 \mathrm{E}+06$ & 100 & 30 & 10 & 3 & 10 & 2 \\
\hline $\mathrm{Pu}-239$ & $1 \mathrm{E}-05$ & $2 \mathrm{E}-05$ & $1.7 \mathrm{E}-05$ & $5 \mathrm{E}-05$ & $3 \mathrm{E}-05$ & $8 \mathrm{E}-05$ & 1 & 1 & 1000 & 500 & $1 \mathrm{E}+07$ & $2 \mathrm{E}+06$ & 1000 & 300 & 10 & 3 & 10 & 2 \\
\hline
\end{tabular}




\section{A-4.1.3 Accident Scenario: Water Ingress}

Table A-4. $600 \mathrm{MW}(\mathrm{t})$ prismatic $700^{\circ} \mathrm{C}$ ROT-water ingress - short term attenuation factors.

\begin{tabular}{|r|c|c|c|c|}
\hline \multirow{2}{*}{ Nuclide } & \multicolumn{4}{|c|}{$\begin{array}{c}\text { Short Term Barriers to Fission Product Release } \\
\text { (Attenuation Factors) }\end{array}$} \\
\cline { 2 - 5 } & \multicolumn{3}{|c|}{ Accident - HPB } & \multicolumn{2}{c|}{$\begin{array}{c}\text { Accident - Reactor } \\
\text { Building }\end{array}$} \\
\cline { 2 - 5 } & DF 50\% & DF 95\% & DF 50\% & DF 95\% \\
\hline Xe-133 & 1 & 1 & 1 & 1 \\
\hline Kr-85 & 1 & 1 & 1 & 1 \\
\hline Kr-88 & 1 & 1 & 1 & 1 \\
\hline I-131 & 2 & 1 & 10 & 2 \\
\hline I-133 & 2 & 1 & 10 & 2 \\
\hline Te-132 & 2 & 1 & 10 & 2 \\
\hline Cs-137 & 2 & 1 & 10 & 2 \\
\hline Cs-134 & 2 & 1 & 10 & 2 \\
\hline Sr-90 & 2 & 1 & 10 & 2 \\
\hline Ag-110m & 2 & 1 & 10 & 2 \\
\hline Ag-111 & 2 & 1 & 10 & 2 \\
\hline Sb-125 & 2 & 1 & 10 & 2 \\
\hline Ru-103 & 2 & 1 & 10 & 2 \\
\hline Ce-144 & 2 & 1 & 10 & 2 \\
\hline La-140 & 2 & 1 & 10 & 2 \\
\hline Pu-239 & 2 & 1 & 10 & 2 \\
\hline
\end{tabular}


Table A-5. $600 \mathrm{MW}(\mathrm{t})$ prismatic $700^{\circ} \mathrm{C}$ ROT-water ingress-long term release fractions and attenuation factors.

\begin{tabular}{|c|c|c|c|c|c|c|c|c|c|c|c|c|c|c|c|c|c|c|}
\hline \multirow{3}{*}{ Nuclide } & \multicolumn{6}{|c|}{ Sources of Fission Product Release } & \multicolumn{12}{|c|}{ Barriers to Fission Product Release (Attenuation Factors } \\
\hline & \multicolumn{2}{|c|}{$\begin{array}{c}\text { Fract. HM } \\
\text { Contamination }\end{array}$} & \multicolumn{2}{|c|}{$\begin{array}{l}\text { Non-Intact } \\
\text { (In-service } \\
\text { failure) }\end{array}$} & \multicolumn{2}{|c|}{$\begin{array}{l}\text { Incremental } \\
\text { Failure - } \\
\text { Accidents }\end{array}$} & \multicolumn{2}{|c|}{$\begin{array}{c}\text { HM } \\
\text { Accident } \\
\text { Release }\end{array}$} & \multicolumn{2}{|c|}{$\begin{array}{l}\text { Non-intact } \\
\text { Accident } \\
\text { Release }\end{array}$} & \multicolumn{2}{|c|}{$\begin{array}{l}\text { Intact Accident } \\
\text { Release }\end{array}$} & \multicolumn{2}{|c|}{$\begin{array}{l}\text { Accident - } \\
\text { Graphite }\end{array}$} & \multicolumn{2}{|c|}{$\begin{array}{l}\text { Accident - } \\
\text { HPB }\end{array}$} & \multicolumn{2}{|c|}{$\begin{array}{l}\text { Accident - } \\
\text { Reactor } \\
\text { Building }\end{array}$} \\
\hline & $50 \%$ & $95 \%$ & $50 \%$ & $95 \%$ & $50 \%$ & $95 \%$ & $\begin{array}{c}\mathrm{DF} \\
50 \%\end{array}$ & $\begin{array}{c}\mathrm{DF} \\
95 \%\end{array}$ & $\begin{array}{c}\mathrm{DF} \\
50 \%\end{array}$ & $\begin{array}{c}\mathrm{DF} \\
95 \%\end{array}$ & DF $50 \%$ & DF $95 \%$ & $\begin{array}{c}\mathrm{DF} \\
50 \%\end{array}$ & $\begin{array}{c}\mathrm{DF} \\
95 \%\end{array}$ & $\begin{array}{c}\mathrm{DF} \\
50 \%\end{array}$ & $\begin{array}{c}\mathrm{DF} \\
95 \%\end{array}$ & $\begin{array}{c}\mathrm{DF} \\
50 \%\end{array}$ & $\begin{array}{c}\mathrm{DF} \\
95 \%\end{array}$ \\
\hline $\mathrm{Xe}-133$ & $1 \mathrm{E}-05$ & $2 \mathrm{E}-05$ & $7 \mathrm{E}-06$ & $2 \mathrm{E}-05$ & $3 \mathrm{E}-05$ & $2 \mathrm{E}-04$ & 1 & 1 & 5 & 3.33 & $1 \mathrm{E}+07$ & $2 \mathrm{E}+06$ & 1 & 1 & 5 & 2 & 1 & 1 \\
\hline Kr-85 & $1 \mathrm{E}-05$ & $2 \mathrm{E}-05$ & $7 \mathrm{E}-06$ & 2E-05 & $3 \mathrm{E}-05$ & $2 \mathrm{E}-04$ & 1 & 1 & 5 & 3.33 & $1 \mathrm{E}+07$ & $2 \mathrm{E}+06$ & 1 & 1 & 5 & 2 & 1 & 1 \\
\hline $\mathrm{Kr}-88$ & $1 \mathrm{E}-05$ & $2 \mathrm{E}-05$ & $7 \mathrm{E}-06$ & $2 \mathrm{E}-05$ & $3 \mathrm{E}-05$ & $2 \mathrm{E}-04$ & 1 & 1 & 5 & 3.33 & $1 \mathrm{E}+07$ & $2 \mathrm{E}+06$ & 1 & 1 & 5 & 2 & 1 & 1 \\
\hline I-131 & $1 \mathrm{E}-05$ & $2 \mathrm{E}-05$ & 7E-06 & 2E-05 & $3 \mathrm{E}-05$ & $2 \mathrm{E}-04$ & 1 & 1 & 5 & 3.33 & $1 \mathrm{E}+07$ & $2 \mathrm{E}+06$ & 1 & 1 & 2 & 1 & 50 & 10 \\
\hline I-133 & $1 \mathrm{E}-05$ & $2 \mathrm{E}-05$ & $7 \mathrm{E}-06$ & 2E-05 & $3 \mathrm{E}-05$ & 2E-04 & 1 & 1 & 5 & 3.33 & $1 \mathrm{E}+07$ & $2 \mathrm{E}+06$ & 1 & 1 & 2 & 1 & 50 & 10 \\
\hline Te-132 & $1 \mathrm{E}-05$ & $2 \mathrm{E}-05$ & $7 \mathrm{E}-06$ & $2 \mathrm{E}-05$ & $3 \mathrm{E}-05$ & $2 \mathrm{E}-04$ & 1 & 1 & 5 & 3.33 & $1 \mathrm{E}+07$ & $2 \mathrm{E}+06$ & 1 & 1 & 2 & 1 & 50 & 10 \\
\hline Cs-137 & $1 \mathrm{E}-05$ & $2 \mathrm{E}-05$ & $1.7 \mathrm{E}-05$ & $5 \mathrm{E}-05$ & $3 \mathrm{E}-05$ & 2E-04 & 1 & 1 & 1 & 1 & $1 \mathrm{E}+07$ & $2 \mathrm{E}+06$ & 5 & 2 & 2 & 1 & 50 & 10 \\
\hline Cs-134 & $1 \mathrm{E}-05$ & $2 \mathrm{E}-05$ & $1.7 \mathrm{E}-05$ & $5 \mathrm{E}-05$ & $3 \mathrm{E}-05$ & $2 \mathrm{E}-04$ & 1 & 1 & 1 & 1 & $1 \mathrm{E}+07$ & $2 \mathrm{E}+06$ & 5 & 2 & 2 & 1 & 50 & 10 \\
\hline $\mathrm{Sr}-90$ & $1 \mathrm{E}-05$ & $2 \mathrm{E}-05$ & $1.7 \mathrm{E}-05$ & 5E-05 & $3 \mathrm{E}-05$ & 2E-04 & 1 & 1 & 1 & 1 & $1 \mathrm{E}+06$ & $2 \mathrm{E}+05$ & 50 & 10 & 2 & 1 & 50 & 10 \\
\hline Ag-110m & $1 \mathrm{E}-05$ & $2 \mathrm{E}-05$ & $1.7 \mathrm{E}-05$ & $5 \mathrm{E}-05$ & $3 \mathrm{E}-05$ & $2 \mathrm{E}-04$ & 1 & 1 & 1 & 1 & $5 \mathrm{E}+02$ & $1 \mathrm{E}+02$ & 1 & 1 & 2 & 1 & 50 & 10 \\
\hline Ag-111 & $1 \mathrm{E}-05$ & $2 \mathrm{E}-05$ & $1.7 \mathrm{E}-05$ & $5 \mathrm{E}-05$ & $3 \mathrm{E}-05$ & $2 \mathrm{E}-04$ & 1 & 1 & 1 & 1 & $5 \mathrm{E}+02$ & $1 \mathrm{E}+02$ & 1 & 1 & 2 & 1 & 50 & 10 \\
\hline $\mathrm{Sb}-125$ & $1 \mathrm{E}-05$ & $2 \mathrm{E}-05$ & $1.7 \mathrm{E}-05$ & 5E-05 & $3 \mathrm{E}-05$ & $2 \mathrm{E}-04$ & 1 & 1 & 1 & 1 & $1 \mathrm{E}+06$ & $2 \mathrm{E}+05$ & 100 & 30 & 2 & 1 & 50 & 10 \\
\hline Ru-103 & $1 \mathrm{E}-05$ & 2E-05 & $1.7 \mathrm{E}-05$ & $5 \mathrm{E}-05$ & $3 \mathrm{E}-05$ & 2E-04 & 1 & 1 & 100 & 50 & $1 \mathrm{E}+07$ & $2 \mathrm{E}+06$ & 10 & 3 & 2 & 1 & 50 & 10 \\
\hline $\mathrm{Ce}-144$ & $1 \mathrm{E}-05$ & $2 \mathrm{E}-05$ & $1.7 \mathrm{E}-05$ & 5E-05 & $3 \mathrm{E}-05$ & 2E-04 & 1 & 1 & 100 & 50 & $1 \mathrm{E}+07$ & $2 \mathrm{E}+06$ & 100 & 30 & 2 & 1 & 50 & 10 \\
\hline La-140 & $1 \mathrm{E}-05$ & $2 \mathrm{E}-05$ & $1.7 \mathrm{E}-05$ & $5 \mathrm{E}-05$ & $3 \mathrm{E}-05$ & 2E-04 & 1 & 1 & 100 & 50 & $1 \mathrm{E}+07$ & $2 \mathrm{E}+06$ & 100 & 30 & 2 & 1 & 50 & 10 \\
\hline Pu-239 & $1 \mathrm{E}-05$ & $2 \mathrm{E}-05$ & $1.7 \mathrm{E}-05$ & $5 \mathrm{E}-05$ & $3 \mathrm{E}-05$ & 2E-04 & 1 & 1 & 1000 & 500 & $1 \mathrm{E}+07$ & $2 \mathrm{E}+06$ & 1000 & 300 & 2 & 1 & 50 & 10 \\
\hline
\end{tabular}


A-4.2 $600 \mathrm{MW}(\mathrm{t})$ Prismatic $900^{\circ} \mathrm{C}$

\section{A-4.2.1 Normal Operations}

Table A-6. $600 \mathrm{MW}(\mathrm{t})$ prismatic $900^{\circ} \mathrm{C}$ ROT - normal operations - release fractions and attenuation factors.

\begin{tabular}{|c|c|c|c|c|c|c|c|c|c|c|c|c|c|c|}
\hline \multirow{3}{*}{ Nuclide } & \multicolumn{6}{|c|}{ Sources of Fission Product Release } & \multicolumn{8}{|c|}{ Barriers to Fission Product Release (Attenuation Factors) } \\
\hline & \multicolumn{2}{|c|}{$\begin{array}{c}\text { Fract. HM } \\
\text { Contamination }\end{array}$} & \multicolumn{2}{|c|}{$\begin{array}{c}\text { Fraction SiC } \\
\text { Defects }\end{array}$} & \multicolumn{2}{|c|}{ In-Service Failure } & \multicolumn{2}{|c|}{$\begin{array}{c}\text { Heavy Metal } \\
\text { Contamination }\end{array}$} & \multicolumn{2}{|c|}{ Kernel } & \multicolumn{2}{|c|}{$\begin{array}{l}\text { Diffusive Release } \\
\text { thru coating }\end{array}$} & \multicolumn{2}{|c|}{ Graphite } \\
\hline & $50 \%$ & $95 \%$ & $50 \%$ & $95 \%$ & $50 \%$ & $95 \%$ & $50 \%$ & $95 \%$ & $50 \%$ & $95 \%$ & $50 \%$ & $95 \%$ & $50 \%$ & $95 \%$ \\
\hline Xe-133 & $1 \mathrm{E}-05$ & $2 \mathrm{E}-05$ & $\overline{\mathrm{NA}}$ & $\overline{\mathrm{NA}}$ & $1.4 \mathrm{E}-05$ & $7 \mathrm{E}-05$ & 5 & 1.5 & 25 & 8.33 & $5 \mathrm{E}+07$ & $5 \mathrm{E}+06$ & 1 & 1 \\
\hline $\mathrm{Kr}-85$ & $1 \mathrm{E}-05$ & $2 \mathrm{E}-05$ & NA & NA & $1.4 \mathrm{E}-05$ & 7E-05 & 5 & 1.5 & 25 & 8.33 & $5 \mathrm{E}+07$ & $5 \mathrm{E}+06$ & 1 & 1 \\
\hline Kr- 88 & $1 \mathrm{E}-05$ & $2 \mathrm{E}-05$ & NA & NA & $1.4 \mathrm{E}-05$ & $7 \mathrm{E}-05$ & 5 & 1.5 & 25 & 8.33 & $5 \mathrm{E}+07$ & $5 \mathrm{E}+06$ & 1 & 1 \\
\hline $\mathrm{I}-131$ & $1 \mathrm{E}-05$ & $2 \mathrm{E}-05$ & NA & NA & $1.4 \mathrm{E}-05$ & $7 \mathrm{E}-05$ & 5 & 1.5 & 25 & 8.33 & $5 \mathrm{E}+07$ & $5 \mathrm{E}+06$ & 1 & 1 \\
\hline $\mathrm{I}-133$ & $1 \mathrm{E}-05$ & $2 \mathrm{E}-05$ & NA & NA & $1.4 \mathrm{E}-05$ & $7 \mathrm{E}-05$ & 5 & 1.5 & 25 & 8.33 & $5 \mathrm{E}+07$ & $5 \mathrm{E}+06$ & 1 & 1 \\
\hline Te-132 & $1 \mathrm{E}-05$ & 2E-05 & NA & NA & $1.4 \mathrm{E}-05$ & 7E-05 & 5 & 1.5 & 25 & 8.33 & $5 \mathrm{E}+07$ & $5 \mathrm{E}+06$ & 1 & 1 \\
\hline Cs-137 & $1 \mathrm{E}-05$ & 2E-05 & $1 \mathrm{E}-05$ & $3 \mathrm{E}-05$ & $2.1 \mathrm{E}-04$ & $1.05 \mathrm{E}-03$ & 1 & 1 & 1.2 & 1 & $1 \mathrm{E}+07$ & $1 \mathrm{E}+05$ & 2 & 1 \\
\hline Cs-134 & $1 \mathrm{E}-05$ & 2E-05 & $1 \mathrm{E}-05$ & $3 \mathrm{E}-05$ & $2.1 \mathrm{E}-04$ & $1.05 \mathrm{E}-03$ & 1 & 1 & 1.2 & 1 & $1 \mathrm{E}+07$ & $1 \mathrm{E}+05$ & 2 & 1 \\
\hline Sr-90 & $1 \mathrm{E}-05$ & 2E-05 & $1 \mathrm{E}-05$ & $3 \mathrm{E}-05$ & $2.1 \mathrm{E}-04$ & $1.05 \mathrm{E}-03$ & 1 & 1 & 3 & 1 & 500 & 100 & 100 & 30 \\
\hline $\mathrm{Ag}-110 \mathrm{~m}$ & $1 \mathrm{E}-05$ & $2 \mathrm{E}-05$ & $1 \mathrm{E}-05$ & $3 \mathrm{E}-05$ & $2.1 \mathrm{E}-04$ & $1.05 \mathrm{E}-03$ & 1 & 1 & 1 & 1 & 200 & 40 & 1 & 1 \\
\hline Ag-111 & $1 \mathrm{E}-05$ & $2 \mathrm{E}-05$ & $1 \mathrm{E}-05$ & $3 \mathrm{E}-05$ & $2.1 \mathrm{E}-04$ & $1.05 \mathrm{E}-03$ & 1 & 1 & 1 & 1 & 200 & 40 & 1 & 1 \\
\hline Sb-125 & $1 \mathrm{E}-05$ & 2E-05 & $1 \mathrm{E}-05$ & $3 \mathrm{E}-05$ & $2.1 \mathrm{E}-04$ & $1.05 \mathrm{E}-03$ & 1 & 1 & 1 & 1 & $5 \mathrm{E}+07$ & $5 \mathrm{E}+05$ & 5 & 1 \\
\hline Ru-103 & $1 \mathrm{E}-05$ & $2 \mathrm{E}-05$ & $1 \mathrm{E}-05$ & $3 \mathrm{E}-05$ & $2.1 \mathrm{E}-04$ & $1.05 \mathrm{E}-03$ & 1 & 1 & 250 & 15 & $1 \mathrm{E}+07$ & $1 \mathrm{E}+06$ & 200 & 60 \\
\hline Ce-144 & $1 \mathrm{E}-05$ & $2 \mathrm{E}-05$ & $1 \mathrm{E}-05$ & $3 \mathrm{E}-05$ & $2.1 \mathrm{E}-04$ & $1.05 \mathrm{E}-03$ & 1 & 1 & 250 & 15 & $1 \mathrm{E}+07$ & $1 \mathrm{E}+06$ & 200 & 60 \\
\hline La-140 & $1 \mathrm{E}-05$ & $2 \mathrm{E}-05$ & $1 \mathrm{E}-05$ & $3 \mathrm{E}-05$ & $2.1 \mathrm{E}-04$ & $1.05 \mathrm{E}-03$ & 1 & 1 & 250 & 15 & $1 \mathrm{E}+07$ & $1 \mathrm{E}+06$ & 200 & 60 \\
\hline $\mathrm{Pu}-239$ & $1 \mathrm{E}-05$ & 2E-05 & $1 \mathrm{E}-05$ & $3 \mathrm{E}-05$ & $2.1 \mathrm{E}-04$ & $1.05 \mathrm{E}-03$ & 1 & 1 & 500 & 50 & $1 \mathrm{E}+07$ & $1 \mathrm{E}+06$ & $5 \mathrm{E}+03$ & 500 \\
\hline
\end{tabular}




\section{A-4.2.2 Accident Scenario: Break in Helium Pressure Boundary}

Table A-7. $600 \mathrm{MW}(\mathrm{t})$ prismatic $900^{\circ} \mathrm{C}$ ROT - break in HPB — short term attenuation factors.

\begin{tabular}{|c|c|c|c|c|}
\hline \multirow{3}{*}{ Nuclide } & \multicolumn{4}{|c|}{$\begin{array}{l}\text { Short Term Barriers to Fission Product Release } \\
\text { (Attenuation Factors) }\end{array}$} \\
\hline & \multicolumn{2}{|c|}{ Accident - HPB } & \multicolumn{2}{|c|}{$\begin{array}{l}\text { Accident - Reactor } \\
\text { Building }\end{array}$} \\
\hline & DF $50 \%$ & DF $95 \%$ & DF $50 \%$ & DF $95 \%$ \\
\hline Xe-133 & 1 & 1 & 1 & 1 \\
\hline $\mathrm{Kr}-85$ & 1 & 1 & 1 & 1 \\
\hline $\mathrm{Kr}-88$ & 1 & 1 & 1 & 1 \\
\hline I-131 & 200 & 20 & 2 & 1 \\
\hline I-133 & 200 & 20 & 2 & 1 \\
\hline Te-132 & 200 & 20 & 2 & 1 \\
\hline Cs-137 & 200 & 20 & 2 & 1 \\
\hline Cs-134 & 200 & 20 & 2 & 1 \\
\hline Sr-90 & 200 & 20 & 2 & 1 \\
\hline Ag-110m & 200 & 20 & 2 & 1 \\
\hline Ag-111 & 200 & 20 & 2 & 1 \\
\hline Sb-125 & 200 & 20 & 2 & 1 \\
\hline Ru-103 & 200 & 20 & 2 & 1 \\
\hline Ce-144 & 200 & 20 & 2 & 1 \\
\hline La-140 & 200 & 20 & 2 & 1 \\
\hline $\mathrm{Pu}-239$ & 200 & 20 & 2 & 1 \\
\hline
\end{tabular}


Table A-8. $600 \mathrm{MW}(\mathrm{t})$ prismatic $900^{\circ} \mathrm{C}$ ROT - break in HPB - long term release fractions and attenuation factors.

\begin{tabular}{|c|c|c|c|c|c|c|c|c|c|c|c|c|c|c|c|c|c|c|}
\hline \multirow{3}{*}{ Nuclide } & \multicolumn{6}{|c|}{ Sources of Fission Product Release } & \multicolumn{12}{|c|}{ Barriers to Fission Product Release (Attenuation Factors } \\
\hline & \multicolumn{2}{|c|}{$\begin{array}{c}\text { Fract. HM } \\
\text { Contamination }\end{array}$} & \multicolumn{2}{|c|}{$\begin{array}{c}\text { Non-Intact } \\
\text { (In-service failure) }\end{array}$} & \multicolumn{2}{|c|}{$\begin{array}{c}\text { Incremental } \\
\text { Failure - } \\
\text { Accidents }\end{array}$} & \multicolumn{2}{|c|}{$\begin{array}{c}\text { HM } \\
\text { Accident } \\
\text { Release }\end{array}$} & \multicolumn{2}{|c|}{$\begin{array}{c}\text { Non-intact } \\
\text { Accident } \\
\text { Release }\end{array}$} & \multicolumn{2}{|c|}{$\begin{array}{c}\text { Intact Accident } \\
\text { Release }\end{array}$} & \multicolumn{2}{|c|}{$\begin{array}{l}\text { Accident - } \\
\text { Graphite }\end{array}$} & \multicolumn{2}{|c|}{$\begin{array}{l}\text { Accident - } \\
\text { HPB }\end{array}$} & \multicolumn{2}{|c|}{$\begin{array}{c}\text { Accident - } \\
\text { Reactor } \\
\text { Building }\end{array}$} \\
\hline & $50 \%$ & $95 \%$ & $50 \%$ & $95 \%$ & $50 \%$ & $95 \%$ & $\begin{array}{c}\mathrm{DF} \\
50 \%\end{array}$ & $\begin{array}{c}\mathrm{DF} \\
95 \%\end{array}$ & $\begin{array}{c}\mathrm{DF} \\
50 \%\end{array}$ & $\begin{array}{c}\mathrm{DF} \\
95 \%\end{array}$ & $\begin{array}{c}\text { DF } \\
50 \%\end{array}$ & $\begin{array}{c}\text { DF } \\
95 \%\end{array}$ & $\begin{array}{c}\text { DF } \\
50 \%\end{array}$ & $\begin{array}{l}\mathrm{DF} \\
95 \%\end{array}$ & $\begin{array}{c}\mathrm{DF} \\
50 \%\end{array}$ & $\begin{array}{c}\text { DF } \\
95 \%\end{array}$ & $\begin{array}{c}\mathrm{DF} \\
50 \%\end{array}$ & $\begin{array}{l}\mathrm{DF} \\
95 \%\end{array}$ \\
\hline $\mathrm{Xe}-133$ & $1 \mathrm{E}-05$ & $2 \mathrm{E}-05$ & 1.4E-05 & 7E-05 & $3 \mathrm{E}-05$ & $8 \mathrm{E}-05$ & 2 & 1 & 10 & 5 & $1 \mathrm{E}+07$ & $2 \mathrm{E}+06$ & 1 & 1 & 5 & 2 & 1 & 1 \\
\hline $\mathrm{Kr}-85$ & $1 \mathrm{E}-05$ & $2 \mathrm{E}-05$ & 1.4E-05 & $7 \mathrm{E}-05$ & $3 \mathrm{E}-05$ & $8 \mathrm{E}-05$ & 2 & 1 & 10 & 5 & $1 \mathrm{E}+07$ & $2 \mathrm{E}+06$ & 1 & 1 & 5 & 2 & 1 & 1 \\
\hline $\mathrm{Kr}-88$ & $1 \mathrm{E}-05$ & $2 \mathrm{E}-05$ & 1.4E-05 & 7E-05 & $3 \mathrm{E}-05$ & $8 \mathrm{E}-05$ & 2 & 1 & 10 & 5 & $1 \mathrm{E}+07$ & $2 \mathrm{E}+06$ & 1 & 1 & 5 & 2 & 1 & 1 \\
\hline I-131 & $1 \mathrm{E}-05$ & $2 \mathrm{E}-05$ & $1.4 \mathrm{E}-05$ & 7E-05 & $3 \mathrm{E}-05$ & $8 \mathrm{E}-05$ & 2 & 1 & 10 & 5 & $1 \mathrm{E}+07$ & $2 \mathrm{E}+06$ & 1 & 1 & 5 & 2 & 10 & 2 \\
\hline I-133 & $1 \mathrm{E}-05$ & $2 \mathrm{E}-05$ & 1.4E-05 & $7 \mathrm{E}-05$ & $3 \mathrm{E}-05$ & $8 \mathrm{E}-05$ & 2 & 1 & 10 & 5 & $1 \mathrm{E}+07$ & $2 \mathrm{E}+06$ & 1 & 1 & 5 & 2 & 10 & 2 \\
\hline Te-132 & $1 \mathrm{E}-05$ & $2 \mathrm{E}-05$ & $1.4 \mathrm{E}-05$ & 7E-05 & $3 \mathrm{E}-05$ & $8 \mathrm{E}-05$ & 2 & 1 & 10 & 5 & $1 \mathrm{E}+07$ & $2 \mathrm{E}+06$ & 1 & 1 & 5 & 2 & 10 & 2 \\
\hline Cs-137 & $1 \mathrm{E}-05$ & $2 \mathrm{E}-05$ & $2.2 \mathrm{E}-04$ & $1.08 \mathrm{E}-03$ & $3 \mathrm{E}-05$ & $8 \mathrm{E}-05$ & 1 & 1 & 1 & 1 & $1 \mathrm{E}+07$ & $2 \mathrm{E}+06$ & 10 & 3 & 10 & 3 & 10 & 2 \\
\hline Cs-134 & $1 \mathrm{E}-05$ & $2 \mathrm{E}-05$ & $2.2 \mathrm{E}-04$ & $1.08 \mathrm{E}-03$ & $3 \mathrm{E}-05$ & $8 \mathrm{E}-05$ & 1 & 1 & 1 & 1 & $1 \mathrm{E}+07$ & $2 \mathrm{E}+06$ & 10 & 3 & 10 & 3 & 10 & 2 \\
\hline Sr-90 & 1E-05 & 2E-05 & $2.2 \mathrm{E}-04$ & $1.08 \mathrm{E}-03$ & $3 \mathrm{E}-05$ & $8 \mathrm{E}-05$ & 1 & 1 & 1 & 1 & $1 \mathrm{E}+06$ & $2 \mathrm{E}+05$ & 100 & 30 & 10 & 3 & 10 & 2 \\
\hline $\mathrm{Ag}-110 \mathrm{~m}$ & $1 \mathrm{E}-05$ & $2 \mathrm{E}-05$ & $2.2 \mathrm{E}-04$ & $1.08 \mathrm{E}-03$ & $3 \mathrm{E}-05$ & $8 \mathrm{E}-05$ & 1 & 1 & 1 & 1 & $5 \mathrm{E}+02$ & $1 \mathrm{E}+02$ & 1 & 1 & 10 & 3 & 10 & 2 \\
\hline Ag-111 & 1E-05 & $2 \mathrm{E}-05$ & 2.2E-04 & $1.08 \mathrm{E}-03$ & 3E-05 & $8 \mathrm{E}-05$ & 1 & 1 & 1 & 1 & $5 \mathrm{E}+02$ & $1 \mathrm{E}+02$ & 1 & 1 & 10 & 3 & 10 & 2 \\
\hline $\mathrm{Sb}-125$ & $1 \mathrm{E}-05$ & $2 \mathrm{E}-05$ & 2.2E-04 & $1.08 \mathrm{E}-03$ & $3 \mathrm{E}-05$ & $8 \mathrm{E}-05$ & 1 & 1 & 1 & 1 & $1 \mathrm{E}+06$ & $2 \mathrm{E}+05$ & 100 & 30 & 10 & 3 & 10 & 2 \\
\hline Ru-103 & $1 \mathrm{E}-05$ & $2 \mathrm{E}-05$ & $2.2 \mathrm{E}-04$ & $1.08 \mathrm{E}-03$ & $3 \mathrm{E}-05$ & $8 \mathrm{E}-05$ & 1 & 1 & 100 & 50 & $1 \mathrm{E}+07$ & $2 \mathrm{E}+06$ & 10 & 3 & 10 & 3 & 10 & 2 \\
\hline $\mathrm{Ce}-144$ & $1 \mathrm{E}-05$ & $2 \mathrm{E}-05$ & $2.2 \mathrm{E}-04$ & $1.08 \mathrm{E}-03$ & $3 \mathrm{E}-05$ & $8 \mathrm{E}-05$ & 1 & 1 & 100 & 50 & $1 \mathrm{E}+07$ & $2 \mathrm{E}+06$ & 100 & 30 & 10 & 3 & 10 & 2 \\
\hline La-140 & $1 \mathrm{E}-05$ & $2 \mathrm{E}-05$ & 2.2E-04 & $1.08 \mathrm{E}-03$ & $3 \mathrm{E}-05$ & $8 \mathrm{E}-05$ & 1 & 1 & 100 & 50 & $1 \mathrm{E}+07$ & $2 \mathrm{E}+06$ & 100 & 30 & 10 & 3 & 10 & 2 \\
\hline Pu-239 & $1 \mathrm{E}-05$ & $2 \mathrm{E}-05$ & 2.2E-04 & $1.08 \mathrm{E}-03$ & $3 \mathrm{E}-05$ & $8 \mathrm{E}-05$ & 1 & 1 & 1000 & 500 & $1 \mathrm{E}+07$ & $2 \mathrm{E}+06$ & 1000 & 300 & 10 & 3 & 10 & 2 \\
\hline
\end{tabular}




\section{A-4.3 250 MW(t) Pebble Bed $700^{\circ} \mathrm{C}$}

\section{A-4.3.1 Normal Operations}

Table A-9. $250 \mathrm{MW}(\mathrm{t})$ pebble bed $700^{\circ} \mathrm{C}$ ROT - normal operations - release fractions and attenuation factors.

\begin{tabular}{|c|c|c|c|c|c|c|c|c|c|c|c|c|c|c|}
\hline \multirow{3}{*}{ Nuclide } & \multicolumn{6}{|c|}{ Sources of Fission Product Release } & \multicolumn{8}{|c|}{ Barriers to Fission Product Release (Attenuation Factors) } \\
\hline & \multicolumn{2}{|c|}{$\begin{array}{c}\text { Fract. HM } \\
\text { Contamination }\end{array}$} & \multicolumn{2}{|c|}{$\begin{array}{l}\text { Fraction } \mathrm{SiC} \\
\text { Defects }\end{array}$} & \multicolumn{2}{|c|}{ In-Service Failure } & \multicolumn{2}{|c|}{$\begin{array}{l}\text { Heavy Metal } \\
\text { Contamination }\end{array}$} & \multicolumn{2}{|c|}{ Kernel } & \multicolumn{2}{|c|}{$\begin{array}{l}\text { Diffusive Release } \\
\text { thru coating }\end{array}$} & \multicolumn{2}{|c|}{ Graphite } \\
\hline & $50 \%$ & $95 \%$ & $50 \%$ & $95 \%$ & $50 \%$ & $95 \%$ & $50 \%$ & $95 \%$ & $50 \%$ & $95 \%$ & $50 \%$ & $95 \%$ & $50 \%$ & $95 \%$ \\
\hline Xe-133 & $1 \mathrm{E}-05$ & $2 \mathrm{E}-05$ & NA & NA & 7E-06 & $2 \mathrm{E}-05$ & 15 & 4.5 & 75 & 25.5 & $1 \mathrm{E}+06$ & $1 \mathrm{E}+05$ & 1 & 1 \\
\hline $\mathrm{Kr}-85$ & $1 \mathrm{E}-05$ & $2 \mathrm{E}-05$ & NA & NA & 7E-06 & $2 \mathrm{E}-05$ & 15 & 4.5 & 75 & 25.5 & $1 \mathrm{E}+06$ & $1 \mathrm{E}+05$ & 1 & 1 \\
\hline $\mathrm{Kr}-88$ & $1 \mathrm{E}-05$ & $2 \mathrm{E}-05$ & NA & NA & $7 \mathrm{E}-06$ & $2 \mathrm{E}-05$ & 15 & 4.5 & 75 & 25.5 & $1 \mathrm{E}+06$ & $1 \mathrm{E}+05$ & 1 & 1 \\
\hline I-131 & $1 \mathrm{E}-05$ & $2 \mathrm{E}-05$ & NA & NA & 7E-06 & $2 \mathrm{E}-05$ & 15 & 4.5 & 75 & 25.5 & $1 \mathrm{E}+06$ & $1 \mathrm{E}+05$ & 1 & 1 \\
\hline I-133 & $1 \mathrm{E}-05$ & $2 \mathrm{E}-05$ & NA & NA & 7E-06 & $2 \mathrm{E}-05$ & 15 & 4.5 & 75 & 25.5 & $1 \mathrm{E}+06$ & $1 E+05$ & 1 & 1 \\
\hline Te-132 & $1 \mathrm{E}-05$ & $2 \mathrm{E}-05$ & NA & NA & 7E-06 & $2 \mathrm{E}-05$ & 15 & 4.5 & 75 & 25.5 & $1 \mathrm{E}+06$ & $1 \mathrm{E}+05$ & 1 & 1 \\
\hline Cs-137 & $1 \mathrm{E}-05$ & $2 \mathrm{E}-05$ & $1 \mathrm{E}-05$ & $3 \mathrm{E}-05$ & $7 \mathrm{E}-06$ & $2 \mathrm{E}-05$ & 1 & 1 & 20 & 8 & $1 \mathrm{E}+06$ & $1 \mathrm{E}+04$ & 5 & 1 \\
\hline Cs-134 & $1 \mathrm{E}-05$ & $2 \mathrm{E}-05$ & $1 \mathrm{E}-05$ & $3 \mathrm{E}-05$ & 7E-06 & $2 \mathrm{E}-05$ & 1 & 1 & 20 & 8 & $1 \mathrm{E}+06$ & $1 \mathrm{E}+04$ & 5 & 1 \\
\hline Sr-90 & $1 \mathrm{E}-05$ & $2 \mathrm{E}-05$ & $1 \mathrm{E}-05$ & $3 \mathrm{E}-05$ & 7E-06 & $2 \mathrm{E}-05$ & 1 & 1 & 200 & 80 & 800 & 200 & 50 & 15 \\
\hline $\mathrm{Ag}-110 \mathrm{~m}$ & $1 \mathrm{E}-05$ & $2 \mathrm{E}-05$ & $1 \mathrm{E}-05$ & $3 \mathrm{E}-05$ & 7E-06 & 2E-05 & 1 & 1 & 8 & 4 & 40 & 4 & 1 & 1 \\
\hline Ag-111 & $1 \mathrm{E}-05$ & $2 \mathrm{E}-05$ & $1 \mathrm{E}-05$ & $3 \mathrm{E}-05$ & 7E-06 & $2 \mathrm{E}-05$ & 1 & 1 & 8 & 4 & 40 & 4 & 1 & 1 \\
\hline Sb-125 & $1 \mathrm{E}-05$ & $2 \mathrm{E}-05$ & $1 \mathrm{E}-05$ & $3 \mathrm{E}-05$ & $7 \mathrm{E}-06$ & $2 \mathrm{E}-05$ & 1 & 1 & 8 & 4 & $1 \mathrm{E}+06$ & $1 \mathrm{E}+04$ & 10 & 1 \\
\hline Ru-103 & $1 \mathrm{E}-05$ & $2 \mathrm{E}-05$ & $1 \mathrm{E}-05$ & $3 \mathrm{E}-05$ & $7 \mathrm{E}-06$ & $2 \mathrm{E}-05$ & 1 & 1 & 2000 & 120 & $1 \mathrm{E}+06$ & $1 \mathrm{E}+05$ & 100 & 30 \\
\hline $\mathrm{Ce}-144$ & $1 \mathrm{E}-05$ & $2 \mathrm{E}-05$ & $1 \mathrm{E}-05$ & $3 \mathrm{E}-05$ & 7E-06 & $2 \mathrm{E}-05$ & 1 & 1 & 2000 & 120 & $1 \mathrm{E}+06$ & $1 \mathrm{E}+05$ & 100 & 30 \\
\hline La-140 & $1 \mathrm{E}-05$ & $2 \mathrm{E}-05$ & $1 \mathrm{E}-05$ & $3 \mathrm{E}-05$ & 7E-06 & $2 \mathrm{E}-05$ & 1 & 1 & 2000 & 120 & $1 \mathrm{E}+06$ & $1 \mathrm{E}+05$ & 100 & 30 \\
\hline Pu-239 & $1 \mathrm{E}-05$ & $2 \mathrm{E}-05$ & $1 \mathrm{E}-05$ & $3 \mathrm{E}-05$ & $7 \mathrm{E}-06$ & $2 \mathrm{E}-05$ & 1 & 1 & 4000 & 400 & $1 \mathrm{E}+06$ & $1 \mathrm{E}+05$ & 1000 & 100 \\
\hline
\end{tabular}




\section{A-4.3.2 Accident Scenario: Break in Helium Pressure Boundary}

Table A-10. $250 \mathrm{MW}(\mathrm{t})$ pebble bed $700^{\circ} \mathrm{C}$ ROT - break in HPB — short term attenuation factors.

\begin{tabular}{|c|c|c|c|c|}
\hline \multirow{3}{*}{ Nuclide } & \multicolumn{4}{|c|}{$\begin{array}{l}\text { Short Term Barriers to Fission Product Release } \\
\text { (Attenuation Factors) }\end{array}$} \\
\hline & \multicolumn{2}{|c|}{ Accident - HPB } & \multicolumn{2}{|c|}{$\begin{array}{l}\text { Accident - Reactor } \\
\text { Building }\end{array}$} \\
\hline & DF $50 \%$ & DF $95 \%$ & DF $50 \%$ & DF $95 \%$ \\
\hline Xe-133 & 1 & 1 & 1 & 1 \\
\hline $\mathrm{Kr}-85$ & 1 & 1 & 1 & 1 \\
\hline $\mathrm{Kr}-88$ & 1 & 1 & 1 & 1 \\
\hline $\mathrm{I}-131$ & 200 & 20 & 2 & 1 \\
\hline I-133 & 200 & 20 & 2 & 1 \\
\hline Te-132 & 200 & 20 & 2 & 1 \\
\hline Cs-137 & 200 & 20 & 2 & 1 \\
\hline Cs-134 & 200 & 20 & 2 & 1 \\
\hline Sr-90 & 200 & 20 & 2 & 1 \\
\hline Ag-110m & 200 & 20 & 2 & 1 \\
\hline Ag-111 & 200 & 20 & 2 & 1 \\
\hline $\mathrm{Sb}-125$ & 200 & 20 & 2 & 1 \\
\hline Ru-103 & 200 & 20 & 2 & 1 \\
\hline $\mathrm{Ce}-144$ & 200 & 20 & 2 & 1 \\
\hline La-140 & 200 & 20 & 2 & 1 \\
\hline $\mathrm{Pu}-239$ & 200 & 20 & 2 & 1 \\
\hline
\end{tabular}


Table A-11. $250 \mathrm{MW}(\mathrm{t})$ pebble bed $700^{\circ} \mathrm{C}$ ROT - break in HPB - long term release fractions and attenuation factors.

\begin{tabular}{|c|c|c|c|c|c|c|c|c|c|c|c|c|c|c|c|c|c|c|}
\hline \multirow{3}{*}{ Nuclide } & \multicolumn{6}{|c|}{ Sources of Fission Product Release } & \multicolumn{12}{|c|}{ Barriers to Fission Product Release (Attenuation Factors } \\
\hline & \multicolumn{2}{|c|}{$\begin{array}{c}\text { Fract. HM } \\
\text { Contamination }\end{array}$} & \multicolumn{2}{|c|}{$\begin{array}{l}\text { Non-Intact } \\
\text { (In-service } \\
\text { failure) }\end{array}$} & \multicolumn{2}{|c|}{$\begin{array}{c}\text { Incremental } \\
\text { Failure - } \\
\text { Accidents }\end{array}$} & \multicolumn{2}{|c|}{$\begin{array}{l}\text { HM } \\
\text { Accident } \\
\text { Release }\end{array}$} & \multicolumn{2}{|c|}{$\begin{array}{l}\text { Non-intact } \\
\text { Accident } \\
\text { Release }\end{array}$} & \multicolumn{2}{|c|}{$\begin{array}{l}\text { Intact Accident } \\
\text { Release }\end{array}$} & \multicolumn{2}{|c|}{$\begin{array}{l}\text { Accident - } \\
\text { Graphite }\end{array}$} & \multicolumn{2}{|c|}{$\begin{array}{c}\text { Accident - } \\
\text { HPB }\end{array}$} & \multicolumn{2}{|c|}{$\begin{array}{l}\text { Accident - } \\
\text { Reactor } \\
\text { Building }\end{array}$} \\
\hline & $50 \%$ & $95 \%$ & $50 \%$ & $95 \%$ & $50 \%$ & $95 \%$ & $\begin{array}{l}\text { DF } \\
50 \\
\%\end{array}$ & $\begin{array}{l}\text { DF } \\
95 \\
\%\end{array}$ & $\begin{array}{c}\text { DF } \\
50 \%\end{array}$ & $\begin{array}{c}\text { DF } \\
95 \%\end{array}$ & $\begin{array}{c}\text { DF } \\
50 \%\end{array}$ & DF $95 \%$ & $\begin{array}{c}\mathrm{DF} \\
50 \%\end{array}$ & $\begin{array}{c}\text { DF } \\
95 \%\end{array}$ & $\begin{array}{c}\mathrm{DF} \\
50 \%\end{array}$ & $\begin{array}{l}\text { DF } \\
95 \\
\%\end{array}$ & $\begin{array}{c}\text { DF } \\
50 \%\end{array}$ & $\begin{array}{l}\text { DF } \\
95 \\
\%\end{array}$ \\
\hline Xe-133 & $1 \mathrm{E}-05$ & $2 \mathrm{E}-05$ & 7E-06 & $2 \mathrm{E}-05$ & $3 \mathrm{E}-05$ & $8 \mathrm{E}-05$ & 2 & 1 & 10 & 5 & $1 \mathrm{E}+07$ & $2 \mathrm{E}+06$ & 1 & 1 & 5 & 2 & 1 & 1 \\
\hline $\mathrm{Kr}-85$ & $1 \mathrm{E}-05$ & $2 \mathrm{E}-05$ & 7E-06 & $2 \mathrm{E}-05$ & $3 \mathrm{E}-05$ & $8 \mathrm{E}-05$ & 2 & 1 & 10 & 5 & $1 \mathrm{E}+07$ & $2 \mathrm{E}+06$ & 1 & 1 & 5 & 2 & 1 & 1 \\
\hline $\mathrm{Kr}-88$ & $1 \mathrm{E}-05$ & $2 \mathrm{E}-05$ & 7E-06 & $2 \mathrm{E}-05$ & $3 \mathrm{E}-05$ & $8 \mathrm{E}-05$ & 2 & 1 & 10 & 5 & $1 \mathrm{E}+07$ & $2 \mathrm{E}+06$ & 1 & 1 & 5 & 2 & 1 & 1 \\
\hline I-131 & $1 \mathrm{E}-05$ & $2 \mathrm{E}-05$ & $7 \mathrm{E}-06$ & $2 \mathrm{E}-05$ & $3 \mathrm{E}-05$ & $8 \mathrm{E}-05$ & 2 & 1 & 10 & 5 & $1 \mathrm{E}+07$ & $2 \mathrm{E}+06$ & 1 & 1 & 5 & 2 & 10 & 2 \\
\hline I-133 & $1 \mathrm{E}-05$ & $2 \mathrm{E}-05$ & $7 \mathrm{E}-06$ & $2 \mathrm{E}-05$ & $3 \mathrm{E}-05$ & $8 \mathrm{E}-05$ & 2 & 1 & 10 & 5 & $1 \mathrm{E}+07$ & $2 \mathrm{E}+06$ & 1 & 1 & 5 & 2 & 10 & 2 \\
\hline Te-132 & $1 \mathrm{E}-05$ & $2 \mathrm{E}-05$ & $7 \mathrm{E}-06$ & $2 \mathrm{E}-05$ & $3 \mathrm{E}-05$ & $8 \mathrm{E}-05$ & 2 & 1 & 10 & 5 & $1 \mathrm{E}+07$ & $2 \mathrm{E}+06$ & 1 & 1 & 5 & 2 & 10 & 2 \\
\hline Cs-137 & $1 \mathrm{E}-05$ & $2 \mathrm{E}-05$ & $1.7 \mathrm{E}-05$ & $5 \mathrm{E}-05$ & $3 \mathrm{E}-05$ & $8 \mathrm{E}-05$ & 1 & 1 & 1 & 1 & $1 \mathrm{E}+07$ & $2 \mathrm{E}+06$ & 10 & 3 & 10 & 3 & 10 & 2 \\
\hline Cs-134 & $1 \mathrm{E}-05$ & $2 \mathrm{E}-05$ & $1.7 \mathrm{E}-05$ & $5 \mathrm{E}-05$ & $3 \mathrm{E}-05$ & $8 \mathrm{E}-05$ & 1 & 1 & 1 & 1 & $1 \mathrm{E}+07$ & $2 \mathrm{E}+06$ & 10 & 3 & 10 & 3 & 10 & 2 \\
\hline Sr-90 & $1 \mathrm{E}-05$ & $2 \mathrm{E}-05$ & $1.7 \mathrm{E}-05$ & $5 \mathrm{E}-05$ & $3 \mathrm{E}-05$ & $8 \mathrm{E}-05$ & 1 & 1 & 1 & 1 & $1 \mathrm{E}+06$ & $2 \mathrm{E}+05$ & 100 & 30 & 10 & 3 & 10 & 2 \\
\hline Ag- $110 \mathrm{~m}$ & $1 \mathrm{E}-05$ & $2 \mathrm{E}-05$ & $1.7 \mathrm{E}-05$ & $5 \mathrm{E}-05$ & $3 \mathrm{E}-05$ & $8 \mathrm{E}-05$ & 1 & 1 & 1 & 1 & $5 \mathrm{E}+02$ & $1 \mathrm{E}+02$ & 1 & 1 & 10 & 3 & 10 & 2 \\
\hline Ag-111 & $1 \mathrm{E}-05$ & $2 \mathrm{E}-05$ & $1.7 \mathrm{E}-05$ & $5 \mathrm{E}-05$ & $3 \mathrm{E}-05$ & $8 \mathrm{E}-05$ & 1 & 1 & 1 & 1 & $5 \mathrm{E}+02$ & $1 \mathrm{E}+02$ & 1 & 1 & 10 & 3 & 10 & 2 \\
\hline Sb-125 & $1 \mathrm{E}-05$ & $2 \mathrm{E}-05$ & $1.7 \mathrm{E}-05$ & $5 \mathrm{E}-05$ & $3 \mathrm{E}-05$ & $8 \mathrm{E}-05$ & 1 & 1 & 1 & 1 & $1 \mathrm{E}+06$ & $2 \mathrm{E}+05$ & 100 & 30 & 10 & 3 & 10 & 2 \\
\hline Ru-103 & $1 \mathrm{E}-05$ & $2 \mathrm{E}-05$ & $1.7 \mathrm{E}-05$ & $5 \mathrm{E}-05$ & $3 \mathrm{E}-05$ & $8 \mathrm{E}-05$ & 1 & 1 & 100 & 50 & $1 \mathrm{E}+07$ & $2 \mathrm{E}+06$ & 10 & 3 & 10 & 3 & 10 & 2 \\
\hline Ce-144 & $1 \mathrm{E}-05$ & $2 \mathrm{E}-05$ & $1.7 \mathrm{E}-05$ & $5 \mathrm{E}-05$ & $3 \mathrm{E}-05$ & $8 \mathrm{E}-05$ & 1 & 1 & 100 & 50 & $1 \mathrm{E}+07$ & $2 \mathrm{E}+06$ & 100 & 30 & 10 & 3 & 10 & 2 \\
\hline La-140 & $1 \mathrm{E}-05$ & $2 \mathrm{E}-05$ & $1.7 \mathrm{E}-05$ & $5 \mathrm{E}-05$ & $3 \mathrm{E}-05$ & $8 \mathrm{E}-05$ & 1 & 1 & 100 & 50 & $1 \mathrm{E}+07$ & $2 \mathrm{E}+06$ & 100 & 30 & 10 & 3 & 10 & 2 \\
\hline $\mathrm{Pu}-239$ & $1 \mathrm{E}-05$ & $2 \mathrm{E}-05$ & $1.7 \mathrm{E}-05$ & $5 \mathrm{E}-05$ & $3 \mathrm{E}-05$ & $8 \mathrm{E}-05$ & 1 & 1 & 1000 & 500 & $1 \mathrm{E}+07$ & $2 \mathrm{E}+06$ & 1000 & 300 & 10 & 3 & 10 & 2 \\
\hline
\end{tabular}




\section{A-4.3.3 Accident Scenario: Water Ingress}

Table A-12. $250 \mathrm{MW}(\mathrm{t})$ pebble bed $700^{\circ} \mathrm{C}$ ROT - water ingress - short term attenuation factors.

\begin{tabular}{|c|c|c|c|c|}
\hline \multirow{2}{*}{ Nuclide } & \multicolumn{3}{|c|}{$\begin{array}{c}\text { Barriers to Fission Product Release } \\
\text { (Attenuation Factors) }\end{array}$} \\
\cline { 2 - 5 } & \multicolumn{2}{|c|}{ Accident - HPB } & \multicolumn{2}{c|}{$\begin{array}{c}\text { Accident - } \\
\text { Reactor Building }\end{array}$} \\
\cline { 2 - 5 } & DF 50\% & DF 95\% & $\begin{array}{c}\text { DF } \\
50 \%\end{array}$ & DF 95\% \\
\hline Xe-133 & 1 & 1 & 1 & 1 \\
\hline Kr-85 & 1 & 1 & 1 & 1 \\
\hline Kr-88 & 1 & 1 & 1 & 1 \\
\hline I-131 & 2 & 1 & 10 & 2 \\
\hline I-133 & 2 & 1 & 10 & 2 \\
\hline Te-132 & 2 & 1 & 10 & 2 \\
\hline Cs-137 & 2 & 1 & 10 & 2 \\
\hline Cs-134 & 2 & 1 & 10 & 2 \\
\hline Sr-90 & 2 & 1 & 10 & 2 \\
\hline Ag-110m & 2 & 1 & 10 & 2 \\
\hline Ag-111 & 2 & 1 & 10 & 2 \\
\hline Sb-125 & 2 & 1 & 10 & 2 \\
\hline Ru-103 & 2 & 1 & 10 & 2 \\
\hline Ce-144 & 2 & 1 & 10 & 2 \\
\hline La-140 & 2 & 1 & 10 & 2 \\
\hline Pu-239 & 2 & 1 & 10 & 2 \\
\hline & & & & \\
\hline & 2 & 1 & 10 \\
\hline
\end{tabular}


Table A-13. $250 \mathrm{MW}(\mathrm{t})$ pebble bed $700^{\circ} \mathrm{C}$ ROT — water ingress - long term release fractions and attenuation factors.

\begin{tabular}{|c|c|c|c|c|c|c|c|c|c|c|c|c|c|c|c|c|c|c|}
\hline \multirow{3}{*}{ Nuclide } & \multicolumn{6}{|c|}{ Sources of Fission Product Release } & \multicolumn{12}{|c|}{ Barriers to Fission Product Release (Attenuation Factors) } \\
\hline & \multicolumn{2}{|c|}{$\begin{array}{c}\text { Fract. HM } \\
\text { Contamination }\end{array}$} & \multicolumn{2}{|c|}{$\begin{array}{c}\text { Non-Intact } \\
\text { (In-service } \\
\text { failure) }\end{array}$} & \multicolumn{2}{|c|}{$\begin{array}{c}\text { Incremental } \\
\text { Failure - } \\
\text { Accidents }\end{array}$} & \multicolumn{2}{|c|}{$\begin{array}{l}\text { HM Accident } \\
\text { Release }\end{array}$} & \multicolumn{2}{|c|}{$\begin{array}{c}\text { Non-intact } \\
\text { Accident } \\
\text { Release }\end{array}$} & \multicolumn{2}{|c|}{$\begin{array}{c}\text { Intact Accident } \\
\text { Release }\end{array}$} & \multicolumn{2}{|c|}{$\begin{array}{c}\text { Accident - } \\
\text { Graphite }\end{array}$} & \multicolumn{2}{|c|}{$\begin{array}{l}\text { Accident - } \\
\text { HPB }\end{array}$} & \multicolumn{2}{|c|}{$\begin{array}{c}\text { Accident - } \\
\text { Reactor } \\
\text { Building }\end{array}$} \\
\hline & $50 \%$ & $95 \%$ & $50 \%$ & $95 \%$ & $50 \%$ & $95 \%$ & $\begin{array}{c}\text { DF } \\
50 \%\end{array}$ & $\begin{array}{c}\mathrm{DF} \\
95 \%\end{array}$ & $\begin{array}{c}\text { DF } \\
50 \%\end{array}$ & $\begin{array}{c}\mathrm{DF} \\
95 \%\end{array}$ & $\begin{array}{c}\text { DF } \\
50 \%\end{array}$ & $\begin{array}{c}\text { DF } \\
95 \%\end{array}$ & $\begin{array}{c}\mathrm{DF} \\
50 \%\end{array}$ & $\begin{array}{c}\mathrm{DF} \\
95 \%\end{array}$ & $\begin{array}{c}\mathrm{DF} \\
50 \%\end{array}$ & $\begin{array}{c}\text { DF } \\
95 \%\end{array}$ & $\begin{array}{c}\mathrm{DF} \\
50 \%\end{array}$ & $\begin{array}{c}\mathrm{DF} \\
95 \%\end{array}$ \\
\hline Xe-133 & $1 \mathrm{E}-05$ & $2 \mathrm{E}-05$ & 7E-06 & $2 \mathrm{E}-05$ & $3 \mathrm{E}-05$ & $2 \mathrm{E}-04$ & 1 & 1 & 5 & 3.33 & $1 \mathrm{E}+07$ & $2 \mathrm{E}+06$ & 1 & 1 & 5 & 2 & 1 & 1 \\
\hline $\mathrm{Kr}-85$ & $1 \mathrm{E}-05$ & $2 \mathrm{E}-05$ & 7E-06 & $2 \mathrm{E}-05$ & $3 \mathrm{E}-05$ & $2 \mathrm{E}-04$ & 1 & 1 & 5 & 3.33 & $1 \mathrm{E}+07$ & $2 \mathrm{E}+06$ & 1 & 1 & 5 & 2 & 1 & 1 \\
\hline $\mathrm{Kr}-88$ & $1 \mathrm{E}-05$ & $2 \mathrm{E}-05$ & 7E-06 & $2 \mathrm{E}-05$ & $3 \mathrm{E}-05$ & 2E-04 & 1 & 1 & 5 & 3.33 & $1 \mathrm{E}+07$ & $2 \mathrm{E}+06$ & 1 & 1 & 5 & 2 & 1 & 1 \\
\hline I-131 & $1 \mathrm{E}-05$ & 2E-05 & 7E-06 & $2 \mathrm{E}-05$ & $3 \mathrm{E}-05$ & 2E-04 & 1 & 1 & 5 & 3.33 & $1 \mathrm{E}+07$ & $2 \mathrm{E}+06$ & 1 & 1 & 2 & 1 & 50 & 10 \\
\hline I-133 & $1 \mathrm{E}-05$ & $2 \mathrm{E}-05$ & 7E-06 & $2 \mathrm{E}-05$ & $3 \mathrm{E}-05$ & 2E-04 & 1 & 1 & 5 & 3.33 & $1 \mathrm{E}+07$ & $2 \mathrm{E}+06$ & 1 & 1 & 2 & 1 & 50 & 10 \\
\hline Te-132 & $1 \mathrm{E}-05$ & $2 \mathrm{E}-05$ & $7 \mathrm{E}-06$ & $2 \mathrm{E}-05$ & $3 \mathrm{E}-05$ & 2E-04 & 1 & 1 & 5 & 3.33 & $1 \mathrm{E}+07$ & $2 \mathrm{E}+06$ & 1 & 1 & 2 & 1 & 50 & 10 \\
\hline Cs-137 & $1 \mathrm{E}-05$ & 2E-05 & $1.7 \mathrm{E}-05$ & $5 \mathrm{E}-05$ & $3 \mathrm{E}-05$ & 2E-04 & 1 & 1 & 1 & 1 & $1 \mathrm{E}+07$ & $2 \mathrm{E}+06$ & 5 & 2 & 2 & 1 & 50 & 10 \\
\hline Cs-134 & $1 \mathrm{E}-05$ & $2 \mathrm{E}-05$ & $1.7 \mathrm{E}-05$ & $5 \mathrm{E}-05$ & $3 \mathrm{E}-05$ & $2 \mathrm{E}-04$ & 1 & 1 & 1 & 1 & $1 \mathrm{E}+07$ & $2 \mathrm{E}+06$ & 5 & 2 & 2 & 1 & 50 & 10 \\
\hline Sr-90 & $1 \mathrm{E}-05$ & $2 \mathrm{E}-05$ & $1.7 \mathrm{E}-05$ & $5 \mathrm{E}-05$ & $3 \mathrm{E}-05$ & 2E-04 & 1 & 1 & 1 & 1 & $1 E+06$ & $2 \mathrm{E}+05$ & 50 & 10 & 2 & 1 & 50 & 10 \\
\hline $\mathrm{Ag}-110 \mathrm{~m}$ & $1 \mathrm{E}-05$ & $2 \mathrm{E}-05$ & $1.7 \mathrm{E}-05$ & $5 \mathrm{E}-05$ & $3 \mathrm{E}-05$ & $2 \mathrm{E}-04$ & 1 & 1 & 1 & 1 & $5 \mathrm{E}+02$ & $1 \mathrm{E}+02$ & 1 & 1 & 2 & 1 & 50 & 10 \\
\hline Ag-111 & $1 \mathrm{E}-05$ & $2 \mathrm{E}-05$ & $1.7 \mathrm{E}-05$ & $5 \mathrm{E}-05$ & $3 \mathrm{E}-05$ & 2E-04 & 1 & 1 & 1 & 1 & $5 \mathrm{E}+02$ & $1 \mathrm{E}+02$ & 1 & 1 & 2 & 1 & 50 & 10 \\
\hline Sb-125 & $1 \mathrm{E}-05$ & $2 \mathrm{E}-05$ & $1.7 \mathrm{E}-05$ & $5 \mathrm{E}-05$ & $3 \mathrm{E}-05$ & 2E-04 & 1 & 1 & 1 & 1 & $1 E+06$ & $2 \mathrm{E}+05$ & 100 & 30 & 2 & 1 & 50 & 10 \\
\hline Ru-103 & $1 \mathrm{E}-05$ & $2 \mathrm{E}-05$ & $1.7 \mathrm{E}-05$ & $5 \mathrm{E}-05$ & $3 \mathrm{E}-05$ & $2 \mathrm{E}-04$ & 1 & 1 & 100 & 50 & $1 \mathrm{E}+07$ & $2 \mathrm{E}+06$ & 10 & 3 & 2 & 1 & 50 & 10 \\
\hline Ce-144 & $1 \mathrm{E}-05$ & $2 \mathrm{E}-05$ & $1.7 \mathrm{E}-05$ & $5 \mathrm{E}-05$ & $3 \mathrm{E}-05$ & 2E-04 & 1 & 1 & 100 & 50 & $1 \mathrm{E}+07$ & $2 \mathrm{E}+06$ & 100 & 30 & 2 & 1 & 50 & 10 \\
\hline La-140 & $1 \mathrm{E}-05$ & $2 \mathrm{E}-05$ & 1.7E-05 & $5 \mathrm{E}-05$ & $3 \mathrm{E}-05$ & 2E-04 & 1 & 1 & 100 & 50 & $1 \mathrm{E}+07$ & $2 \mathrm{E}+06$ & 100 & 30 & 2 & 1 & 50 & 10 \\
\hline $\mathrm{Pu}-239$ & $1 \mathrm{E}-05$ & $2 \mathrm{E}-05$ & $1.7 \mathrm{E}-05$ & $5 \mathrm{E}-05$ & $3 \mathrm{E}-05$ & 2E-04 & 1 & 1 & 1000 & 500 & $1 \mathrm{E}+07$ & $2 \mathrm{E}+06$ & 1000 & 300 & 2 & 1 & 50 & 10 \\
\hline
\end{tabular}


Appendix B

\section{Dose Conversion Factors}




\section{Appendix B \\ Dose Conversion Factors}

\section{B-1. Dose Conversion Factors}

Table B-1. Dose conversion factors-Cases A/B 400 meters (rem/curie).

\begin{tabular}{|c|c|c|}
\hline Nuclide & $\begin{array}{c}\text { Short Term DCF } \\
\text { 95\% Meteorology }\end{array}$ & $\begin{array}{c}\text { Long Term DCF } \\
\text { 95\% Meteorology }\end{array}$ \\
\hline Xe-133 & $4.67 \mathrm{E}-07$ & $3.17 \mathrm{E}-07$ \\
\hline Kr-85 & $3.91 \mathrm{E}-08$ & $2.62 \mathrm{E}-08$ \\
\hline Kr-88 & $3.05 \mathrm{E}-05$ & $1.01 \mathrm{E}-05$ \\
\hline $\mathrm{I}-131$ & $2.00 \mathrm{E}-03$ & $1.14 \mathrm{E}-03$ \\
\hline $\mathrm{I}-133$ & $3.07 \mathrm{E}-04$ & $1.54 \mathrm{E}-04$ \\
\hline Te-132 & $7.46 \mathrm{E}-04$ & $5.17 \mathrm{E}-04$ \\
\hline $\mathrm{Cs}-134$ & $3.02 \mathrm{E}-03$ & $1.94 \mathrm{E}-03$ \\
\hline $\mathrm{Cs}-137$ & $2.02 \mathrm{E}-03$ & $1.20 \mathrm{E}-03$ \\
\hline Sr-90 & $1.02 \mathrm{E}-02$ & $8.97 \mathrm{E}-03$ \\
\hline Ag-110m & $5.04 \mathrm{E}-03$ & $3.21 \mathrm{E}-03$ \\
\hline Ag-111 & $3.03 \mathrm{E}-04$ & $2.18 \mathrm{E}-04$ \\
\hline Sb-125 & $2.08 \mathrm{E}-04$ & $1.23 \mathrm{E}-04$ \\
\hline Ru-103 & $5.16 \mathrm{E}-04$ & $3.65 \mathrm{E}-04$ \\
\hline Ce-144 & $2.00 \mathrm{E}-02$ & $1.29 \mathrm{E}-02$ \\
\hline La-140 & $5.16 \mathrm{E}-04$ & $2.72 \mathrm{E}-04$ \\
\hline Pu-239 & $1.15 \mathrm{E}+01$ & $1.10 \mathrm{E}+01$ \\
\hline
\end{tabular}


Table B-2. Dose conversion factors - Case C (rem/curie).

\begin{tabular}{|c|c|c|c|c|c|c|c|c|c|c|}
\hline \multirow{2}{*}{ Nuclide } & \multicolumn{5}{|c|}{$\begin{array}{c}\text { Short Term DCF } \\
\text { Mean Meteorology }\end{array}$} & \multicolumn{5}{|c|}{$\begin{array}{c}\text { Long Term DCF } \\
\text { Mean Meteorology }\end{array}$} \\
\hline & $400 \mathrm{~m}$ & $800 \mathrm{~m}$ & $1600 \mathrm{~m}$ & $3200 \mathrm{~m}$ & $8000 \mathrm{~m}$ & $400 \mathrm{~m}$ & $800 \mathrm{~m}$ & $1600 \mathrm{~m}$ & $3200 \mathrm{~m}$ & $8000 \mathrm{~m}$ \\
\hline Xe-133 & $1.87 \mathrm{E}-07$ & $9.38 \mathrm{E}-08$ & 4.37E-08 & $1.76 \mathrm{E}-08$ & 4.50E-09 & $1.90 \mathrm{E}-07$ & $9.71 \mathrm{E}-08$ & 4.63E-08 & $1.88 \mathrm{E}-08$ & 4.89E-09 \\
\hline $\mathrm{Kr}-85$ & $1.43 \mathrm{E}-08$ & 7.17E-09 & $3.35 \mathrm{E}-09$ & $1.35 \mathrm{E}-09$ & $3.49 \mathrm{E}-10$ & $1.57 \mathrm{E}-08$ & $8.05 \mathrm{E}-09$ & $3.85 \mathrm{E}-09$ & $1.57 \mathrm{E}-09$ & $4.11 \mathrm{E}-10$ \\
\hline $\mathrm{Kr}-88$ & $1.36 \mathrm{E}-05$ & $7.00 \mathrm{E}-06$ & $3.23 \mathrm{E}-06$ & $1.19 \mathrm{E}-06$ & $2.21 \mathrm{E}-07$ & 4.43E-06 & $2.29 \mathrm{E}-06$ & $1.07 \mathrm{E}-06$ & $3.97 \mathrm{E}-07$ & $7.56 \mathrm{E}-08$ \\
\hline $\mathrm{I}-131$ & $6.18 \mathrm{E}-04$ & $2.14 \mathrm{E}-04$ & 7.39E-05 & $2.38 \mathrm{E}-05$ & $5.08 \mathrm{E}-06$ & $6.92 \mathrm{E}-04$ & $2.40 \mathrm{E}-04$ & $8.27 \mathrm{E}-05$ & $2.67 \mathrm{E}-05$ & $5.70 \mathrm{E}-06$ \\
\hline I-133 & 1.19E-04 & $4.16 \mathrm{E}-05$ & $1.45 \mathrm{E}-05$ & $4.65 \mathrm{E}-06$ & $9.63 \mathrm{E}-07$ & $9.23 \mathrm{E}-05$ & $3.23 \mathrm{E}-05$ & $1.12 \mathrm{E}-05$ & $3.63 \mathrm{E}-06$ & $7.55 \mathrm{E}-07$ \\
\hline Te-132 & $2.68 \mathrm{E}-04$ & $9.50 \mathrm{E}-05$ & 3.39E-05 & $1.15 \mathrm{E}-05$ & 2.64E-06 & $2.82 \mathrm{E}-04$ & $1.01 \mathrm{E}-04$ & 3.63E-05 & $1.23 \mathrm{E}-05$ & $2.81 \mathrm{E}-06$ \\
\hline Cs-134 & $9.42 \mathrm{E}-04$ & $3.28 \mathrm{E}-04$ & $1.14 \mathrm{E}-04$ & $3.73 \mathrm{E}-05$ & $8.09 \mathrm{E}-06$ & $1.09 \mathrm{E}-03$ & $3.81 \mathrm{E}-04$ & $1.33 \mathrm{E}-04$ & 4.33E-05 & $9.42 \mathrm{E}-06$ \\
\hline Cs-137 & $6.54 \mathrm{E}-04$ & $2.28 \mathrm{E}-04$ & 7.95E-05 & $2.59 \mathrm{E}-05$ & 5.64E-06 & $7.59 \mathrm{E}-04$ & $2.64 \mathrm{E}-04$ & $9.22 \mathrm{E}-05$ & $3.01 \mathrm{E}-05$ & $6.55 \mathrm{E}-06$ \\
\hline Sr-90 & $4.36 \mathrm{E}-03$ & $1.51 \mathrm{E}-03$ & $5.19 \mathrm{E}-04$ & $1.67 \mathrm{E}-04$ & $3.57 \mathrm{E}-05$ & $5.20 \mathrm{E}-03$ & $1.80 \mathrm{E}-03$ & $6.18 \mathrm{E}-04$ & $1.99 \mathrm{E}-04$ & $4.25 \mathrm{E}-05$ \\
\hline $\mathrm{Ag}-110 \mathrm{~m}$ & $1.64 \mathrm{E}-03$ & $5.70 \mathrm{E}-04$ & $1.99 \mathrm{E}-04$ & $6.48 \mathrm{E}-05$ & $1.41 \mathrm{E}-05$ & $1.90 \mathrm{E}-03$ & $6.61 \mathrm{E}-04$ & $2.30 \mathrm{E}-04$ & $7.51 \mathrm{E}-05$ & $1.63 \mathrm{E}-05$ \\
\hline Ag-111 & $1.13 \mathrm{E}-04$ & $3.90 \mathrm{E}-05$ & $1.34 \mathrm{E}-05$ & 4.32E-06 & $9.18 \mathrm{E}-07$ & $1.26 \mathrm{E}-04$ & $4.37 \mathrm{E}-05$ & $1.50 \mathrm{E}-05$ & 4.84E-06 & $1.03 \mathrm{E}-06$ \\
\hline Sb-125 & $6.65 \mathrm{E}-05$ & $2.38 \mathrm{E}-05$ & 8.54E-06 & $2.89 \mathrm{E}-06$ & $6.54 \mathrm{E}-07$ & 7.27E-05 & $2.60 \mathrm{E}-05$ & $9.35 \mathrm{E}-06$ & $3.17 \mathrm{E}-06$ & 7.26E-07 \\
\hline $\mathrm{Ru}-103$ & $1.93 \mathrm{E}-04$ & $6.74 \mathrm{E}-05$ & $2.36 \mathrm{E}-05$ & 7.73E-06 & $1.69 \mathrm{E}-06$ & $2.19 \mathrm{E}-04$ & 7.67E-05 & $2.68 \mathrm{E}-05$ & $8.81 \mathrm{E}-06$ & $1.93 \mathrm{E}-06$ \\
\hline Ce-144 & $6.81 \mathrm{E}-03$ & $2.35 \mathrm{E}-03$ & $8.10 \mathrm{E}-04$ & $2.61 \mathrm{E}-04$ & $5.57 \mathrm{E}-05$ & $8.06 \mathrm{E}-03$ & $2.79 \mathrm{E}-03$ & $9.60 \mathrm{E}-04$ & $3.09 \mathrm{E}-04$ & $6.59 \mathrm{E}-05$ \\
\hline La-140 & $1.64 \mathrm{E}-04$ & $5.98 \mathrm{E}-05$ & $2.17 \mathrm{E}-05$ & 7.39E-06 & $1.65 \mathrm{E}-06$ & $1.49 \mathrm{E}-04$ & $5.43 \mathrm{E}-05$ & $1.99 \mathrm{E}-05$ & $6.80 \mathrm{E}-06$ & $1.54 \mathrm{E}-06$ \\
\hline $\mathrm{Pu}-239$ & $5.61 \mathrm{E}+00$ & $1.94 \mathrm{E}+00$ & $6.68 \mathrm{E}-01$ & $2.15 \mathrm{E}-01$ & $4.59 \mathrm{E}-02$ & $6.65 \mathrm{E}+00$ & $2.30 \mathrm{E}+00$ & $7.92 \mathrm{E}-01$ & $2.55 \mathrm{E}-01$ & $5.44 \mathrm{E}-02$ \\
\hline
\end{tabular}

Table B-3. Dose conversion factors - Case D (rem/curie).

\begin{tabular}{|c|c|c|c|c|c|c|c|c|c|c|}
\hline \multirow{2}{*}{ Nuclide } & \multicolumn{5}{|c|}{$\begin{array}{c}\text { Short Term DCF } \\
\text { Mean Meteorology }\end{array}$} & \multicolumn{5}{|c|}{$\begin{array}{l}\text { Long Term DCF } \\
\text { Mean Meteorology }\end{array}$} \\
\hline & $400 \mathrm{~m}$ & $800 \mathrm{~m}$ & $1600 \mathrm{~m}$ & $3200 \mathrm{~m}$ & $8000 \mathrm{~m}$ & $400 \mathrm{~m}$ & $800 \mathrm{~m}$ & $1600 \mathrm{~m}$ & $3200 \mathrm{~m}$ & $8000 \mathrm{~m}$ \\
\hline $\mathrm{I}-131$ & $1.96 \mathrm{E}-02$ & $6.78 \mathrm{E}-03$ & $2.33 \mathrm{E}-03$ & 7.49E-04 & $1.59 \mathrm{E}-04$ & $2.21 \mathrm{E}-02$ & 7.63E-03 & $2.62 \mathrm{E}-03$ & $8.43 \mathrm{E}-04$ & $1.79 \mathrm{E}-04$ \\
\hline $\mathrm{I}-133$ & $3.23 \mathrm{E}-03$ & $1.11 \mathrm{E}-03$ & $3.78 \mathrm{E}-04$ & $1.19 \mathrm{E}-04$ & $2.41 \mathrm{E}-05$ & $2.50 \mathrm{E}-03$ & $8.58 \mathrm{E}-04$ & $2.92 \mathrm{E}-04$ & $9.23 \mathrm{E}-05$ & $1.87 \mathrm{E}-05$ \\
\hline Te-132 & $4.31 \mathrm{E}-03$ & $1.49 \mathrm{E}-03$ & $5.13 \mathrm{E}-04$ & $1.65 \mathrm{E}-04$ & $3.52 \mathrm{E}-05$ & $4.58 \mathrm{E}-03$ & $1.58 \mathrm{E}-03$ & $5.46 \mathrm{E}-04$ & $1.76 \mathrm{E}-04$ & $3.72 \mathrm{E}-05$ \\
\hline
\end{tabular}


Table B-4. Dose conversion factors - Case E, infant, whole body (rem/curie).

\begin{tabular}{|c|c|c|c|c|c|c|c|c|c|c|}
\hline \multirow{2}{*}{ Nuclide } & \multicolumn{5}{|c|}{$\begin{array}{l}\text { Short Term DCF } \\
\text { Mean Meteorology }\end{array}$} & \multicolumn{5}{|c|}{$\begin{array}{l}\text { Long Term DCF } \\
\text { Mean Meteorology }\end{array}$} \\
\hline & $400 \mathrm{~m}$ & $800 \mathrm{~m}$ & $1600 \mathrm{~m}$ & $3200 \mathrm{~m}$ & $8000 \mathrm{~m}$ & $400 \mathrm{~m}$ & $800 \mathrm{~m}$ & $1600 \mathrm{~m}$ & $3200 \mathrm{~m}$ & $8000 \mathrm{~m}$ \\
\hline Xe-133 & - & - & - & - & - & - & - & - & - & - \\
\hline $\mathrm{Kr}-85$ & - & - & - & - & - & - & - & - & - & - \\
\hline $\mathrm{Kr}-88$ & - & - & - & - & - & - & - & - & - & - \\
\hline $\mathrm{I}-131$ & $2.32 \mathrm{E}-02$ & $8.54 \mathrm{E}-03$ & $3.11 \mathrm{E}-03$ & $1.06 \mathrm{E}-03$ & $2.54 \mathrm{E}-04$ & $2.51 \mathrm{E}-02$ & $9.35 \mathrm{E}-03$ & $3.53 \mathrm{E}-03$ & $1.27 \mathrm{E}-03$ & $3.11 \mathrm{E}-04$ \\
\hline $\mathrm{I}-133$ & $9.97 \mathrm{E}-04$ & $3.65 \mathrm{E}-04$ & $1.32 \mathrm{E}-04$ & $4.42 \mathrm{E}-05$ & $1.02 \mathrm{E}-05$ & 7.36E-04 & $2.73 \mathrm{E}-04$ & $1.02 \mathrm{E}-04$ & $3.63 \mathrm{E}-05$ & $8.58 \mathrm{E}-06$ \\
\hline Te-132 & $6.26 \mathrm{E}-05$ & $2.30 \mathrm{E}-05$ & $8.38 \mathrm{E}-06$ & $2.84 \mathrm{E}-06$ & $6.78 \mathrm{E}-07$ & $6.27 \mathrm{E}-05$ & $2.33 \mathrm{E}-05$ & 8.82E-06 & $3.16 \mathrm{E}-06$ & $7.70 \mathrm{E}-07$ \\
\hline Cs-134 & $9.96 \mathrm{E}-03$ & $3.66 \mathrm{E}-03$ & $1.33 \mathrm{E}-03$ & $4.55 \mathrm{E}-04$ & $1.10 \mathrm{E}-04$ & $1.13 \mathrm{E}-02$ & $4.21 \mathrm{E}-03$ & $1.59 \mathrm{E}-03$ & $5.72 \mathrm{E}-04$ & $1.41 \mathrm{E}-04$ \\
\hline Cs-137 & $8.68 \mathrm{E}-03$ & $3.19 \mathrm{E}-03$ & $1.16 \mathrm{E}-03$ & $3.97 \mathrm{E}-04$ & $9.59 \mathrm{E}-05$ & $9.87 \mathrm{E}-03$ & $3.67 \mathrm{E}-03$ & $1.39 \mathrm{E}-03$ & 4.99E-04 & $1.23 \mathrm{E}-04$ \\
\hline Sr-90 & $1.65 \mathrm{E}-02$ & $6.06 \mathrm{E}-03$ & $2.21 \mathrm{E}-03$ & $7.52 \mathrm{E}-04$ & $1.81 \mathrm{E}-04$ & $1.88 \mathrm{E}-02$ & $6.98 \mathrm{E}-03$ & $2.63 \mathrm{E}-03$ & $9.43 \mathrm{E}-04$ & 2.32E-04 \\
\hline Ag-110m & $1.90 \mathrm{E}-02$ & $6.95 \mathrm{E}-03$ & $2.53 \mathrm{E}-03$ & $8.63 \mathrm{E}-04$ & $2.08 \mathrm{E}-04$ & $2.15 \mathrm{E}-02$ & $8.00 \mathrm{E}-03$ & $3.01 \mathrm{E}-03$ & $1.08 \mathrm{E}-03$ & $2.66 \mathrm{E}-04$ \\
\hline Ag-111 & $3.34 \mathrm{E}-03$ & $1.23 \mathrm{E}-03$ & $4.48 \mathrm{E}-04$ & $1.52 \mathrm{E}-04$ & $3.66 \mathrm{E}-05$ & $3.59 \mathrm{E}-03$ & $1.34 \mathrm{E}-03$ & $5.06 \mathrm{E}-04$ & $1.82 \mathrm{E}-04$ & 4.46E-05 \\
\hline $\mathrm{Sb}-125$ & 8.97E-05 & $3.28 \mathrm{E}-05$ & $1.19 \mathrm{E}-05$ & $4.06 \mathrm{E}-06$ & $9.78 \mathrm{E}-07$ & $1.02 \mathrm{E}-04$ & $3.77 \mathrm{E}-05$ & $1.42 \mathrm{E}-05$ & $5.07 \mathrm{E}-06$ & $1.25 \mathrm{E}-06$ \\
\hline Ru-103 & $1.11 \mathrm{E}-07$ & $4.08 \mathrm{E}-08$ & $1.49 \mathrm{E}-08$ & $5.07 \mathrm{E}-09$ & $1.22 \mathrm{E}-09$ & $1.25 \mathrm{E}-07$ & $4.66 \mathrm{E}-08$ & $1.76 \mathrm{E}-08$ & $6.33 \mathrm{E}-09$ & $1.56 \mathrm{E}-09$ \\
\hline Ce-144 & $5.34 \mathrm{E}-05$ & $1.96 \mathrm{E}-05$ & $7.14 \mathrm{E}-06$ & $2.43 \mathrm{E}-06$ & $5.86 \mathrm{E}-07$ & $6.07 \mathrm{E}-05$ & $2.25 \mathrm{E}-05$ & $8.49 \mathrm{E}-06$ & $3.05 \mathrm{E}-06$ & $7.50 \mathrm{E}-07$ \\
\hline La-140 & $1.44 \mathrm{E}-06$ & $5.28 \mathrm{E}-07$ & $1.92 \mathrm{E}-07$ & $6.48 \mathrm{E}-08$ & $1.53 \mathrm{E}-08$ & $1.29 \mathrm{E}-06$ & 4.79E-07 & $1.80 \mathrm{E}-07$ & $6.45 \mathrm{E}-08$ & $1.55 \mathrm{E}-08$ \\
\hline $\mathrm{Pu}-239$ & $1.91 \mathrm{E}-05$ & $7.00 \mathrm{E}-06$ & $2.55 \mathrm{E}-06$ & 8.68E-07 & 2.09E-07 & $2.17 \mathrm{E}-05$ & 8.07E-06 & $3.03 \mathrm{E}-06$ & $1.09 \mathrm{E}-06$ & $2.68 \mathrm{E}-07$ \\
\hline
\end{tabular}


Table B-5. Dose conversion factors - Case E, adult, whole body (rem/curie).

\begin{tabular}{|c|c|c|c|c|c|c|c|c|c|c|}
\hline \multirow{2}{*}{ Nuclide } & \multicolumn{5}{|c|}{$\begin{array}{l}\text { Short Term DCF } \\
\text { Mean Meteorology }\end{array}$} & \multicolumn{5}{|c|}{$\begin{array}{l}\text { Long Term DCF } \\
\text { Mean Meteorology }\end{array}$} \\
\hline & $400 \mathrm{~m}$ & $800 \mathrm{~m}$ & $1600 \mathrm{~m}$ & $3200 \mathrm{~m}$ & $8000 \mathrm{~m}$ & $400 \mathrm{~m}$ & $800 \mathrm{~m}$ & $1600 \mathrm{~m}$ & $3200 \mathrm{~m}$ & $8000 \mathrm{~m}$ \\
\hline Xe-133 & - & - & - & - & - & - & - & - & - & - \\
\hline $\mathrm{Kr}-85$ & - & - & - & - & - & - & - & - & - & - \\
\hline $\mathrm{Kr}-88$ & - & - & - & - & - & - & - & - & - & - \\
\hline $\mathrm{I}-131$ & $1.44 \mathrm{E}-03$ & $5.30 \mathrm{E}-04$ & $1.93 \mathrm{E}-04$ & $6.57 \mathrm{E}-05$ & $1.58 \mathrm{E}-05$ & $1.56 \mathrm{E}-03$ & $5.81 \mathrm{E}-04$ & $2.20 \mathrm{E}-04$ & $7.89 \mathrm{E}-05$ & $1.93 \mathrm{E}-05$ \\
\hline $\mathrm{I}-133$ & 4.49E-05 & $1.64 \mathrm{E}-05$ & $5.95 \mathrm{E}-06$ & $1.99 \mathrm{E}-06$ & $4.60 \mathrm{E}-07$ & $3.32 \mathrm{E}-05$ & $1.23 \mathrm{E}-05$ & 4.62E-06 & $1.64 \mathrm{E}-06$ & $3.87 \mathrm{E}-07$ \\
\hline Te-132 & $2.61 \mathrm{E}-06$ & $9.58 \mathrm{E}-07$ & $3.49 \mathrm{E}-07$ & $1.18 \mathrm{E}-07$ & $2.82 \mathrm{E}-08$ & $2.61 \mathrm{E}-06$ & $9.73 \mathrm{E}-07$ & $3.67 \mathrm{E}-07$ & $1.32 \mathrm{E}-07$ & $3.21 \mathrm{E}-08$ \\
\hline Cs-134 & $6.06 \mathrm{E}-03$ & $2.23 \mathrm{E}-03$ & $8.13 \mathrm{E}-04$ & 2.77E-04 & $6.70 \mathrm{E}-05$ & $6.89 \mathrm{E}-03$ & $2.56 \mathrm{E}-03$ & $9.68 \mathrm{E}-04$ & $3.49 \mathrm{E}-04$ & $8.60 \mathrm{E}-05$ \\
\hline Cs-137 & $4.41 \mathrm{E}-03$ & $1.62 \mathrm{E}-03$ & $5.91 \mathrm{E}-04$ & $2.01 \mathrm{E}-04$ & $4.87 \mathrm{E}-05$ & $5.01 \mathrm{E}-03$ & $1.86 \mathrm{E}-03$ & $7.04 \mathrm{E}-04$ & $2.53 \mathrm{E}-04$ & $6.25 \mathrm{E}-05$ \\
\hline Sr-90 & $2.23 \mathrm{E}-03$ & $8.16 \mathrm{E}-04$ & $2.97 \mathrm{E}-04$ & $1.01 \mathrm{E}-04$ & $2.44 \mathrm{E}-05$ & $2.53 \mathrm{E}-03$ & $9.39 \mathrm{E}-04$ & $3.54 \mathrm{E}-04$ & $1.27 \mathrm{E}-04$ & $3.13 \mathrm{E}-05$ \\
\hline Ag-110m & $1.82 \mathrm{E}-03$ & $6.69 \mathrm{E}-04$ & $2.44 \mathrm{E}-04$ & $8.30 \mathrm{E}-05$ & $2.00 \mathrm{E}-05$ & $2.07 \mathrm{E}-03$ & 7.69E-04 & $2.90 \mathrm{E}-04$ & $1.04 \mathrm{E}-04$ & $2.56 \mathrm{E}-05$ \\
\hline Ag-111 & $2.54 \mathrm{E}-04$ & $9.34 \mathrm{E}-05$ & $3.41 \mathrm{E}-05$ & $1.16 \mathrm{E}-05$ & $2.78 \mathrm{E}-06$ & $2.73 \mathrm{E}-04$ & $1.02 \mathrm{E}-04$ & $3.85 \mathrm{E}-05$ & $1.38 \mathrm{E}-05$ & $3.39 \mathrm{E}-06$ \\
\hline $\mathrm{Sb}-125$ & $5.26 \mathrm{E}-06$ & $1.92 \mathrm{E}-06$ & $6.99 \mathrm{E}-07$ & $2.38 \mathrm{E}-07$ & $5.72 \mathrm{E}-08$ & $5.97 \mathrm{E}-06$ & $2.21 \mathrm{E}-06$ & $8.29 \mathrm{E}-07$ & $2.97 \mathrm{E}-07$ & 7.31E-08 \\
\hline Ru-103 & $1.02 \mathrm{E}-08$ & $3.75 \mathrm{E}-09$ & $1.37 \mathrm{E}-09$ & $4.66 \mathrm{E}-10$ & $1.12 \mathrm{E}-10$ & $1.15 \mathrm{E}-08$ & $4.28 \mathrm{E}-09$ & $1.62 \mathrm{E}-09$ & $5.83 \mathrm{E}-10$ & $1.43 \mathrm{E}-10$ \\
\hline Ce-144 & $3.62 \mathrm{E}-06$ & $1.33 \mathrm{E}-06$ & 4.84E-07 & $1.65 \mathrm{E}-07$ & $3.97 \mathrm{E}-08$ & 4.11E-06 & $1.53 \mathrm{E}-06$ & $5.76 \mathrm{E}-07$ & $2.07 \mathrm{E}-07$ & $5.09 \mathrm{E}-08$ \\
\hline La-140 & $1.33 \mathrm{E}-07$ & $4.90 \mathrm{E}-08$ & $1.78 \mathrm{E}-08$ & $6.01 \mathrm{E}-09$ & $1.42 \mathrm{E}-09$ & $1.19 \mathrm{E}-07$ & 4.45E-08 & $1.67 \mathrm{E}-08$ & $5.98 \mathrm{E}-09$ & $1.44 \mathrm{E}-09$ \\
\hline $\mathrm{Pu}-239$ & 5.07E-08 & $1.86 \mathrm{E}-08$ & $6.76 \mathrm{E}-09$ & $2.30 \mathrm{E}-09$ & $5.55 \mathrm{E}-10$ & $5.77 \mathrm{E}-08$ & $2.14 \mathrm{E}-08$ & 8.05E-09 & 2.89E-09 & $7.11 \mathrm{E}-10$ \\
\hline
\end{tabular}


Table B-6. Dose conversion factors - Case F, infant, thyroid (rem/curie).

\begin{tabular}{|c|c|c|c|c|c|c|c|c|c|c|}
\hline \multirow{2}{*}{ Nuclide } & \multicolumn{5}{|c|}{$\begin{array}{l}\text { Short Term DCF } \\
\text { Mean Meteorology }\end{array}$} & \multicolumn{5}{|c|}{$\begin{array}{l}\text { Long Term DCF } \\
\text { Mean Meteorology }\end{array}$} \\
\hline & $400 \mathrm{~m}$ & $800 \mathrm{~m}$ & $1600 \mathrm{~m}$ & $3200 \mathrm{~m}$ & $8000 \mathrm{~m}$ & $400 \mathrm{~m}$ & $800 \mathrm{~m}$ & $1600 \mathrm{~m}$ & $3200 \mathrm{~m}$ & $8000 \mathrm{~m}$ \\
\hline Xe-133 & - & - & - & - & - & - & - & - & - & - \\
\hline $\mathrm{Kr}-85$ & - & - & - & - & - & - & - & - & - & - \\
\hline $\mathrm{Kr}-88$ & - & - & - & - & - & - & - & - & - & - \\
\hline $\mathrm{I}-131$ & 4.62E-01 & $1.70 \mathrm{E}-01$ & $6.19 \mathrm{E}-02$ & $2.10 \mathrm{E}-02$ & $5.06 \mathrm{E}-03$ & $1.84 \mathrm{E}+00$ & $6.06 \mathrm{E}-01$ & $2.38 \mathrm{E}-01$ & $8.23 \mathrm{E}-02$ & $1.85 \mathrm{E}-02$ \\
\hline $\mathrm{I}-133$ & $1.94 \mathrm{E}-02$ & $7.10 \mathrm{E}-03$ & $2.57 \mathrm{E}-03$ & $8.61 \mathrm{E}-04$ & $1.99 \mathrm{E}-04$ & $7.59 \mathrm{E}-02$ & $2.64 \mathrm{E}-02$ & $9.31 \mathrm{E}-03$ & $3.10 \mathrm{E}-03$ & $7.05 \mathrm{E}-04$ \\
\hline Te-132 & 8.49E-04 & $3.12 \mathrm{E}-04$ & $1.14 \mathrm{E}-04$ & $3.85 \mathrm{E}-05$ & $2.64 \mathrm{E}-06$ & $3.31 \mathrm{E}-03$ & $1.21 \mathrm{E}-03$ & $4.06 \mathrm{E}-04$ & $1.47 \mathrm{E}-04$ & $3.40 \mathrm{E}-05$ \\
\hline Cs-134 & $9.84 \mathrm{E}-03$ & $3.61 \mathrm{E}-03$ & $1.32 \mathrm{E}-03$ & $4.50 \mathrm{E}-04$ & $1.09 \mathrm{E}-04$ & $3.43 \mathrm{E}-02$ & $1.26 \mathrm{E}-02$ & $4.41 \mathrm{E}-03$ & $1.59 \mathrm{E}-03$ & $3.98 \mathrm{E}-04$ \\
\hline Cs-137 & 7.77E-03 & $2.85 \mathrm{E}-03$ & $1.04 \mathrm{E}-03$ & $3.55 \mathrm{E}-04$ & $8.59 \mathrm{E}-05$ & $2.92 \mathrm{E}-02$ & $1.05 \mathrm{E}-02$ & $3.77 \mathrm{E}-03$ & $1.34 \mathrm{E}-03$ & 2.96E-04 \\
\hline Sr-90 & $8.60 \mathrm{E}-04$ & $3.15 \mathrm{E}-04$ & $1.15 \mathrm{E}-04$ & $3.91 \mathrm{E}-05$ & $9.42 \mathrm{E}-06$ & $3.17 \mathrm{E}-03$ & $1.15 \mathrm{E}-03$ & $3.92 \mathrm{E}-04$ & $1.42 \mathrm{E}-04$ & $3.24 \mathrm{E}-05$ \\
\hline Ag-110m & $5.11 \mathrm{E}-03$ & $1.87 \mathrm{E}-03$ & $6.82 \mathrm{E}-04$ & $2.32 \mathrm{E}-04$ & $5.60 \mathrm{E}-05$ & $2.05 \mathrm{E}-02$ & $6.90 \mathrm{E}-03$ & $2.40 \mathrm{E}-03$ & $8.40 \mathrm{E}-04$ & $1.95 \mathrm{E}-04$ \\
\hline Ag-111 & $9.05 \mathrm{E}-05$ & $3.32 \mathrm{E}-05$ & $1.21 \mathrm{E}-05$ & $4.12 \mathrm{E}-06$ & $9.90 \mathrm{E}-07$ & $3.35 \mathrm{E}-04$ & $1.23 \mathrm{E}-04$ & $4.30 \mathrm{E}-05$ & $1.57 \mathrm{E}-05$ & $3.82 \mathrm{E}-06$ \\
\hline $\mathrm{Sb}-125$ & $9.40 \mathrm{E}-05$ & $3.43 \mathrm{E}-05$ & $1.25 \mathrm{E}-05$ & $4.24 \mathrm{E}-06$ & $1.02 \mathrm{E}-06$ & $3.55 \mathrm{E}-04$ & $1.32 \mathrm{E}-04$ & $4.38 \mathrm{E}-05$ & $1.64 \mathrm{E}-05$ & $3.89 \mathrm{E}-06$ \\
\hline Ru-103 & $1.73 \mathrm{E}-08$ & $6.35 \mathrm{E}-09$ & 2.32E-09 & $7.89 \mathrm{E}-10$ & $1.90 \mathrm{E}-10$ & $7.15 \mathrm{E}-08$ & $2.30 \mathrm{E}-08$ & 8.33E-09 & $2.65 \mathrm{E}-09$ & $6.59 \mathrm{E}-10$ \\
\hline Ce-144 & $6.78 \mathrm{E}-07$ & $2.48 \mathrm{E}-07$ & $9.06 \mathrm{E}-08$ & $3.08 \mathrm{E}-08$ & 7.43E-09 & $2.43 \mathrm{E}-06$ & 8.37E-07 & $3.27 \mathrm{E}-07$ & $1.11 \mathrm{E}-07$ & 2.64E-08 \\
\hline La-140 & $9.22 \mathrm{E}-09$ & $3.38 \mathrm{E}-09$ & $1.23 \mathrm{E}-09$ & $4.15 \mathrm{E}-10$ & $9.80 \mathrm{E}-11$ & $3.39 \mathrm{E}-08$ & $1.25 \mathrm{E}-08$ & 4.46E-09 & $1.63 \mathrm{E}-09$ & $3.74 \mathrm{E}-10$ \\
\hline $\mathrm{Pu}-239$ & $2.51 \mathrm{E}-06$ & $9.19 \mathrm{E}-07$ & $3.35 \mathrm{E}-07$ & $1.14 \mathrm{E}-07$ & $2.74 \mathrm{E}-08$ & $9.03 \mathrm{E}-06$ & $3.35 \mathrm{E}-06$ & $1.25 \mathrm{E}-06$ & 4.09E-07 & $9.61 \mathrm{E}-08$ \\
\hline
\end{tabular}


Table B-7. Dose conversion factors - Case F, adult, thyroid (rem/curie).

\begin{tabular}{|c|c|c|c|c|c|c|c|c|c|c|}
\hline \multirow{2}{*}{ Nuclide } & \multicolumn{5}{|c|}{$\begin{array}{l}\text { Short Term DCF } \\
\text { Mean Meteorology }\end{array}$} & \multicolumn{5}{|c|}{$\begin{array}{l}\text { Long Term DCF } \\
\text { Mean Meteorology }\end{array}$} \\
\hline & $400 \mathrm{~m}$ & $800 \mathrm{~m}$ & $1600 \mathrm{~m}$ & $3200 \mathrm{~m}$ & $8000 \mathrm{~m}$ & $400 \mathrm{~m}$ & $800 \mathrm{~m}$ & $1600 \mathrm{~m}$ & $3200 \mathrm{~m}$ & $8000 \mathrm{~m}$ \\
\hline Xe-133 & - & - & - & - & - & - & - & - & - & - \\
\hline $\mathrm{Kr}-85$ & - & - & - & - & - & - & - & - & - & - \\
\hline $\mathrm{Kr}-88$ & - & - & - & - & - & - & - & - & - & - \\
\hline $\mathrm{I}-131$ & 4.77E-02 & $1.75 \mathrm{E}-02$ & $6.39 \mathrm{E}-03$ & $2.17 \mathrm{E}-03$ & $5.22 \mathrm{E}-04$ & $5.15 \mathrm{E}-02$ & $1.92 \mathrm{E}-02$ & $7.26 \mathrm{E}-03$ & $2.61 \mathrm{E}-03$ & $6.39 \mathrm{E}-04$ \\
\hline I-133 & $1.46 \mathrm{E}-03$ & $5.34 \mathrm{E}-04$ & $1.93 \mathrm{E}-04$ & $6.48 \mathrm{E}-05$ & $1.50 \mathrm{E}-05$ & $1.08 \mathrm{E}-03$ & $4.00 \mathrm{E}-04$ & $1.50 \mathrm{E}-04$ & $5.32 \mathrm{E}-05$ & $1.26 \mathrm{E}-05$ \\
\hline Te-132 & $6.11 \mathrm{E}-05$ & $2.24 \mathrm{E}-05$ & $8.17 \mathrm{E}-06$ & $2.77 \mathrm{E}-06$ & $6.61 \mathrm{E}-07$ & $6.11 \mathrm{E}-05$ & $2.28 \mathrm{E}-05$ & $8.60 \mathrm{E}-06$ & $3.09 \mathrm{E}-06$ & 7.52E-07 \\
\hline Cs-134 & $5.39 \mathrm{E}-03$ & $1.98 \mathrm{E}-03$ & $7.23 \mathrm{E}-04$ & $2.46 \mathrm{E}-04$ & $5.96 \mathrm{E}-05$ & $6.13 \mathrm{E}-03$ & $2.28 \mathrm{E}-03$ & 8.61E-04 & $3.10 \mathrm{E}-04$ & $7.65 \mathrm{E}-05$ \\
\hline Cs-137 & $4.11 \mathrm{E}-03$ & $1.51 \mathrm{E}-03$ & $5.51 \mathrm{E}-04$ & $1.88 \mathrm{E}-04$ & $4.54 \mathrm{E}-05$ & $4.68 \mathrm{E}-03$ & $1.74 \mathrm{E}-03$ & $6.57 \mathrm{E}-04$ & $2.36 \mathrm{E}-04$ & $5.83 \mathrm{E}-05$ \\
\hline Sr-90 & $8.73 \mathrm{E}-05$ & $3.20 \mathrm{E}-05$ & $1.17 \mathrm{E}-05$ & $3.97 \mathrm{E}-06$ & $9.57 \mathrm{E}-07$ & $9.93 \mathrm{E}-05$ & $3.68 \mathrm{E}-05$ & $1.39 \mathrm{E}-05$ & $4.98 \mathrm{E}-06$ & $1.23 \mathrm{E}-06$ \\
\hline Ag-110m & $1.13 \mathrm{E}-04$ & 4.14E-05 & $1.51 \mathrm{E}-05$ & $5.14 \mathrm{E}-06$ & $1.24 \mathrm{E}-06$ & $1.28 \mathrm{E}-04$ & 4.77E-05 & $1.80 \mathrm{E}-05$ & $6.45 \mathrm{E}-06$ & $1.59 \mathrm{E}-06$ \\
\hline Ag-111 & $1.39 \mathrm{E}-06$ & $5.10 \mathrm{E}-07$ & $1.86 \mathrm{E}-07$ & $6.32 \mathrm{E}-08$ & $1.52 \mathrm{E}-08$ & $1.49 \mathrm{E}-06$ & $5.56 \mathrm{E}-07$ & $2.10 \mathrm{E}-07$ & $7.56 \mathrm{E}-08$ & $1.85 \mathrm{E}-08$ \\
\hline $\mathrm{Sb}-125$ & $2.64 \mathrm{E}-07$ & $9.66 \mathrm{E}-08$ & $3.52 \mathrm{E}-08$ & $1.20 \mathrm{E}-08$ & $2.88 \mathrm{E}-09$ & $3.00 \mathrm{E}-07$ & $1.11 \mathrm{E}-07$ & 4.17E-08 & $1.50 \mathrm{E}-08$ & $3.68 \mathrm{E}-09$ \\
\hline Ru-103 & $7.72 \mathrm{E}-10$ & $2.84 \mathrm{E}-10$ & $1.04 \mathrm{E}-10$ & $3.52 \mathrm{E}-11$ & $8.50 \mathrm{E}-12$ & $8.69 \mathrm{E}-10$ & $3.24 \mathrm{E}-10$ & $1.22 \mathrm{E}-10$ & $4.40 \mathrm{E}-11$ & $1.08 \mathrm{E}-11$ \\
\hline Ce-144 & $3.27 \mathrm{E}-09$ & $1.20 \mathrm{E}-09$ & 4.37E-10 & $1.49 \mathrm{E}-10$ & $3.59 \mathrm{E}-11$ & $3.71 \mathrm{E}-09$ & $1.38 \mathrm{E}-09$ & $5.20 \mathrm{E}-10$ & $1.87 \mathrm{E}-10$ & $4.59 \mathrm{E}-11$ \\
\hline La-140 & $3.75 \mathrm{E}-10$ & $1.37 \mathrm{E}-10$ & $5.00 \mathrm{E}-11$ & $1.69 \mathrm{E}-11$ & $3.98 \mathrm{E}-12$ & $3.35 \mathrm{E}-10$ & $1.25 \mathrm{E}-10$ & $4.70 \mathrm{E}-11$ & $1.68 \mathrm{E}-11$ & $4.05 \mathrm{E}-12$ \\
\hline $\mathrm{Pu}-239$ & $2.72 \mathrm{E}-13$ & $9.95 \mathrm{E}-14$ & $3.62 \mathrm{E}-14$ & $1.23 \mathrm{E}-14$ & $2.97 \mathrm{E}-15$ & $3.09 \mathrm{E}-13$ & $1.15 \mathrm{E}-13$ & $4.31 \mathrm{E}-14$ & $1.55 \mathrm{E}-14$ & $3.81 \mathrm{E}-15$ \\
\hline
\end{tabular}




\section{B-2. Deposition Factors}

Table B-8. Deposition factors-Case G (curie $/ \mathrm{m}^{2}$ ).

\begin{tabular}{|c|c|c|c|c|c|c|c|c|c|c|}
\hline \multirow{2}{*}{ Nuclide } & \multicolumn{5}{|c|}{$\begin{array}{l}\text { Short Term Deposition } \\
\text { Mean Meteorology }\end{array}$} & \multicolumn{5}{|c|}{$\begin{array}{l}\text { Long Term Deposition } \\
\text { Mean Meteorology }\end{array}$} \\
\hline & $400 \mathrm{~m}$ & $800 \mathrm{~m}$ & $1600 \mathrm{~m}$ & $3200 \mathrm{~m}$ & $8000 \mathrm{~m}$ & $400 \mathrm{~m}$ & $800 \mathrm{~m}$ & $1600 \mathrm{~m}$ & $3200 \mathrm{~m}$ & $8000 \mathrm{~m}$ \\
\hline Xe-133 & - & - & - & - & - & - & - & - & - & - \\
\hline $\mathrm{Kr}-85$ & - & - & - & - & - & - & - & - & - & - \\
\hline $\mathrm{Kr}-88$ & - & - & - & - & - & - & - & - & - & - \\
\hline I-131 & $1.45 \mathrm{E}-07$ & $5.38 \mathrm{E}-08$ & $1.99 \mathrm{E}-08$ & $6.95 \mathrm{E}-09$ & $1.71 \mathrm{E}-09$ & $1.70 \mathrm{E}-07$ & $1.17 \mathrm{E}-07$ & $7.51 \mathrm{E}-08$ & $4.79 \mathrm{E}-08$ & $9.71 \mathrm{E}-09$ \\
\hline I-133 & $1.44 \mathrm{E}-07$ & 5.32E-08 & $1.96 \mathrm{E}-08$ & $6.70 \mathrm{E}-09$ & $1.59 \mathrm{E}-09$ & $1.68 \mathrm{E}-07$ & $9.95 \mathrm{E}-08$ & $5.00 \mathrm{E}-08$ & $2.38 \mathrm{E}-08$ & 4.79E-09 \\
\hline Te-132 & $1.45 \mathrm{E}-07$ & $5.38 \mathrm{E}-08$ & $2.00 \mathrm{E}-08$ & $6.97 \mathrm{E}-09$ & $1.73 \mathrm{E}-09$ & $1.69 \mathrm{E}-07$ & $1.13 \mathrm{E}-07$ & $6.98 \mathrm{E}-08$ & 4.19E-08 & 8.49E-09 \\
\hline Cs-134 & $1.45 \mathrm{E}-07$ & $5.38 \mathrm{E}-08$ & $2.00 \mathrm{E}-08$ & $6.97 \mathrm{E}-09$ & $1.73 \mathrm{E}-09$ & $1.70 \mathrm{E}-07$ & $1.19 \mathrm{E}-07$ & 7.93E-08 & $5.25 \mathrm{E}-08$ & $1.07 \mathrm{E}-08$ \\
\hline Cs-137 & $1.45 \mathrm{E}-07$ & $5.38 \mathrm{E}-08$ & $2.00 \mathrm{E}-08$ & $6.97 \mathrm{E}-09$ & $1.73 \mathrm{E}-09$ & $1.70 \mathrm{E}-07$ & $1.19 \mathrm{E}-07$ & 7.96E-08 & $5.28 \mathrm{E}-08$ & $1.07 \mathrm{E}-08$ \\
\hline Sr-90 & $1.45 \mathrm{E}-07$ & $5.38 \mathrm{E}-08$ & $2.00 \mathrm{E}-08$ & $6.97 \mathrm{E}-09$ & $1.73 \mathrm{E}-09$ & $1.70 \mathrm{E}-07$ & $1.19 \mathrm{E}-07$ & $7.96 \mathrm{E}-08$ & $5.28 \mathrm{E}-08$ & $1.07 \mathrm{E}-08$ \\
\hline Ag-110m & $1.45 \mathrm{E}-07$ & $5.38 \mathrm{E}-08$ & $2.00 \mathrm{E}-08$ & $6.97 \mathrm{E}-09$ & $1.73 \mathrm{E}-09$ & $1.70 \mathrm{E}-07$ & $1.19 \mathrm{E}-07$ & $7.93 \mathrm{E}-08$ & $5.25 \mathrm{E}-08$ & $1.06 \mathrm{E}-08$ \\
\hline Ag-111 & $1.45 \mathrm{E}-07$ & $5.38 \mathrm{E}-08$ & $1.99 \mathrm{E}-08$ & $6.95 \mathrm{E}-09$ & $1.71 \mathrm{E}-09$ & $1.70 \mathrm{E}-07$ & $1.16 \mathrm{E}-07$ & $7.50 \mathrm{E}-08$ & $4.76 \mathrm{E}-08$ & $9.65 \mathrm{E}-09$ \\
\hline $\mathrm{Sb}-125$ & $1.45 \mathrm{E}-07$ & $5.38 \mathrm{E}-08$ & $2.00 \mathrm{E}-08$ & $6.97 \mathrm{E}-09$ & $1.72 \mathrm{E}-09$ & $1.70 \mathrm{E}-07$ & $1.19 \mathrm{E}-07$ & 7.93E-08 & $5.25 \mathrm{E}-08$ & $1.07 \mathrm{E}-08$ \\
\hline Ru-103 & $1.45 \mathrm{E}-07$ & $5.38 \mathrm{E}-08$ & $2.00 \mathrm{E}-08$ & $6.97 \mathrm{E}-09$ & $1.73 \mathrm{E}-09$ & $1.70 \mathrm{E}-07$ & $1.18 \mathrm{E}-07$ & $7.85 \mathrm{E}-08$ & $5.16 \mathrm{E}-08$ & $1.05 \mathrm{E}-08$ \\
\hline Ce-144 & $1.45 \mathrm{E}-07$ & $5.38 \mathrm{E}-08$ & $2.00 \mathrm{E}-08$ & $6.97 \mathrm{E}-09$ & $1.73 \mathrm{E}-09$ & $1.70 \mathrm{E}-07$ & $1.19 \mathrm{E}-07$ & 7.93E-08 & $5.25 \mathrm{E}-08$ & $1.06 \mathrm{E}-08$ \\
\hline La-140 & $1.45 \mathrm{E}-07$ & $5.35 \mathrm{E}-08$ & $1.98 \mathrm{E}-08$ & $6.84 \mathrm{E}-09$ & $1.65 \mathrm{E}-09$ & $1.69 \mathrm{E}-07$ & $1.08 \mathrm{E}-07$ & $6.18 \mathrm{E}-08$ & $3.43 \mathrm{E}-08$ & $6.91 \mathrm{E}-09$ \\
\hline $\mathrm{Pu}-239$ & $1.45 \mathrm{E}-07$ & $5.38 \mathrm{E}-08$ & $2.00 \mathrm{E}-08$ & $6.97 \mathrm{E}-09$ & $1.73 \mathrm{E}-09$ & $1.70 \mathrm{E}-07$ & $1.19 \mathrm{E}-07$ & 7.96E-08 & $5.28 \mathrm{E}-08$ & $1.07 \mathrm{E}-08$ \\
\hline
\end{tabular}


Appendix C Doses 


\section{Appendix C \\ Doses}

\section{C-1. $600 \mathrm{MW}(\mathrm{t})$ Prismatic $700^{\circ} \mathrm{C}$}

\section{C-1.1 Accident Scenario: Break in Helium Pressure Boundary}

\section{C-1.1.1 Source Term}

Table C-1. $600 \mathrm{MW}(\mathrm{t})$ prismatic $700^{\circ} \mathrm{C}$ ROT-break in HPB-source term (curies).

\begin{tabular}{|c|c|c|c|c|c|c|c|c|}
\hline \multirow{2}{*}{ Nuclide } & \multicolumn{4}{|c|}{ Release to Environment Short Term } & \multicolumn{4}{|c|}{ Release to Environment Long Term } \\
\hline & DBA & $50 \%$ & Mean & $95 \%$ & DBA & $50 \%$ & Mean & $95 \%$ \\
\hline $\mathrm{Xe}-133$ & $3.99 \mathrm{E}+01$ & $3.99 \mathrm{E}+01$ & $3.99 \mathrm{E}+01$ & $3.99 \mathrm{E}+01$ & $4.92 \mathrm{E}+01$ & $4.92 \mathrm{E}+01$ & $6.44 \mathrm{E}+01$ & $1.68 \mathrm{E}+02$ \\
\hline $\mathrm{Kr}-85$ & $2.10 \mathrm{E}-01$ & $2.10 \mathrm{E}-01$ & $2.10 \mathrm{E}-01$ & $2.10 \mathrm{E}-01$ & $3.39 \mathrm{E}-01$ & $3.39 \mathrm{E}-01$ & $4.50 \mathrm{E}-01$ & $1.21 \mathrm{E}+00$ \\
\hline Kr- 88 & $2.06 \mathrm{E}+01$ & $2.06 \mathrm{E}+01$ & $2.06 \mathrm{E}+01$ & $2.06 \mathrm{E}+01$ & $1.38 \mathrm{E}-04$ & $1.38 \mathrm{E}-04$ & $1.82 \mathrm{E}-04$ & 4.91E-04 \\
\hline $\mathrm{I}-131$ & $1.10 \mathrm{E}+00$ & $5.51 \mathrm{E}-02$ & $1.61 \mathrm{E}-01$ & $6.10 \mathrm{E}-01$ & $1.02 \mathrm{E}+02$ & $2.85 \mathrm{E}+00$ & $6.11 \mathrm{E}+00$ & $2.24 \mathrm{E}+01$ \\
\hline I-133 & $1.89 \mathrm{E}+00$ & $1.00 \mathrm{E}-01$ & $2.90 \mathrm{E}-01$ & $1.08 \mathrm{E}+00$ & $4.32 \mathrm{E}+01$ & $1.17 \mathrm{E}+00$ & $2.64 \mathrm{E}+00$ & $9.72 \mathrm{E}+00$ \\
\hline Te-132 & $1.50 \mathrm{E}+00$ & $7.44 \mathrm{E}-02$ & $2.17 \mathrm{E}-01$ & $8.08 \mathrm{E}-01$ & $1.11 \mathrm{E}+02$ & $3.12 \mathrm{E}+00$ & $6.51 \mathrm{E}+00$ & $2.41 \mathrm{E}+01$ \\
\hline Cs-137 & $2.59 \mathrm{E}+00$ & $1.17 \mathrm{E}-01$ & $3.43 \mathrm{E}-01$ & $1.33 \mathrm{E}+00$ & $7.58 \mathrm{E}+00$ & $1.15 \mathrm{E}-01$ & $3.31 \mathrm{E}-01$ & $1.28 \mathrm{E}+00$ \\
\hline Cs-134 & $3.58 \mathrm{E}-01$ & $1.93 \mathrm{E}-02$ & $5.54 \mathrm{E}-02$ & $2.10 \mathrm{E}-01$ & $8.47 \mathrm{E}+00$ & $1.32 \mathrm{E}-01$ & $3.82 \mathrm{E}-01$ & $1.49 \mathrm{E}+00$ \\
\hline Sr-90 & $3.08 \mathrm{E}-02$ & $1.57 \mathrm{E}-03$ & $4.56 \mathrm{E}-03$ & $1.72 \mathrm{E}-02$ & $9.65 \mathrm{E}+00$ & $1.79 \mathrm{E}-01$ & $4.71 \mathrm{E}-01$ & $1.76 \mathrm{E}+00$ \\
\hline $\mathrm{Ag}-110 \mathrm{~m}$ & $7.93 \mathrm{E}-01$ & $3.86 \mathrm{E}-02$ & $1.13 \mathrm{E}-01$ & $4.22 \mathrm{E}-01$ & $4.65 \mathrm{E}+01$ & $8.61 \mathrm{E}-01$ & $2.30 \mathrm{E}+00$ & $8.51 \mathrm{E}+00$ \\
\hline Ag-111 & $1.67 \mathrm{E}+01$ & $7.96 \mathrm{E}-01$ & $2.28 \mathrm{E}+00$ & $8.93 \mathrm{E}+00$ & $3.50 \mathrm{E}+03$ & $5.48 \mathrm{E}+01$ & $1.72 \mathrm{E}+02$ & $6.49 \mathrm{E}+02$ \\
\hline $\mathrm{Sb}-125$ & $1.40 \mathrm{E}-02$ & $7.27 \mathrm{E}-04$ & $2.12 \mathrm{E}-03$ & $8.15 \mathrm{E}-03$ & $1.06 \mathrm{E}-01$ & $1.78 \mathrm{E}-03$ & $5.23 \mathrm{E}-03$ & $2.05 \mathrm{E}-02$ \\
\hline Ru-103 & $1.58 \mathrm{E}-02$ & $8.05 \mathrm{E}-04$ & $2.34 \mathrm{E}-03$ & $8.68 \mathrm{E}-03$ & $4.25 \mathrm{E}+01$ & 7.19E-01 & $1.96 \mathrm{E}+00$ & $7.54 \mathrm{E}+00$ \\
\hline Ce-144 & $1.97 \mathrm{E}-01$ & $9.74 \mathrm{E}-03$ & $2.75 \mathrm{E}-02$ & $1.05 \mathrm{E}-01$ & $2.64 \mathrm{E}+00$ & $4.57 \mathrm{E}-02$ & $1.30 \mathrm{E}-01$ & $5.01 \mathrm{E}-01$ \\
\hline La-140 & $1.46 \mathrm{E}-02$ & $7.46 \mathrm{E}-04$ & $2.16 \mathrm{E}-03$ & $8.13 \mathrm{E}-03$ & $1.66 \mathrm{E}+00$ & $2.88 \mathrm{E}-02$ & $7.65 \mathrm{E}-02$ & $2.92 \mathrm{E}-01$ \\
\hline $\mathrm{Pu}-239$ & $3.73 \mathrm{E}-06$ & $1.90 \mathrm{E}-07$ & $5.74 \mathrm{E}-07$ & $2.10 \mathrm{E}-06$ & $5.29 \mathrm{E}-05$ & $8.97 \mathrm{E}-07$ & $2.60 \mathrm{E}-06$ & $1.01 \mathrm{E}-05$ \\
\hline
\end{tabular}




\section{C-1.1.2 Doses}

Table C-2. $600 \mathrm{MW}(\mathrm{t})$ prismatic $700^{\circ} \mathrm{C}$ ROT — break in HPB - Cases A and B- $400 \mathrm{~m}$ from release (rem).

\begin{tabular}{|c|c|c|c|c|}
\hline \multirow[t]{2}{*}{ Nuclide } & \multicolumn{2}{|c|}{$\begin{array}{l}\text { Case A/EAB }(400 \mathrm{~m}) / \\
\text { TEDE }\end{array}$} & \multicolumn{2}{|c|}{$\begin{array}{c}\text { Case B/LPZ }(400 \mathrm{~m}) / \\
\text { TEDE }\end{array}$} \\
\hline & Short & Long & Short & Long \\
\hline Xe-133 & $1.80 \mathrm{E}-05$ & & $1.80 \mathrm{E}-05$ & $5.26 \mathrm{E}-05$ \\
\hline $\mathrm{Kr}-85$ & 8.30E-09 & & 8.30E-09 & $3.01 \mathrm{E}-08$ \\
\hline $\mathrm{Kr}-88$ & $6.18 \mathrm{E}-04$ & & $6.18 \mathrm{E}-04$ & $4.95 \mathrm{E}-09$ \\
\hline $\mathrm{I}-131$ & $2.15 \mathrm{E}-03$ & & $2.15 \mathrm{E}-03$ & $1.19 \mathrm{E}-01$ \\
\hline $\mathrm{I}-133$ & $5.95 \mathrm{E}-04$ & & $5.95 \mathrm{E}-04$ & $6.48 \mathrm{E}-03$ \\
\hline Te-132 & $1.15 \mathrm{E}-03$ & & $1.15 \mathrm{E}-03$ & $5.53 \mathrm{E}-02$ \\
\hline Cs-137 & 4.90E-03 & & $4.90 \mathrm{E}-03$ & $8.71 \mathrm{E}-03$ \\
\hline Cs-134 & $1.07 \mathrm{E}-03$ & & $1.07 \mathrm{E}-03$ & $1.59 \mathrm{E}-02$ \\
\hline Sr-90 & $3.37 \mathrm{E}-04$ & & $3.37 \mathrm{E}-04$ & $8.70 \mathrm{E}-02$ \\
\hline $\mathrm{Ag}-110 \mathrm{~m}$ & $3.69 \mathrm{E}-03$ & & 3.69E-03 & $1.53 \mathrm{E}-01$ \\
\hline Ag-111 & $2.31 \mathrm{E}-02$ & & $2.31 \mathrm{E}-02$ & $9.24 \mathrm{E}-01$ \\
\hline $\mathrm{Sb}-125$ & $3.00 \mathrm{E}-06$ & & $3.00 \mathrm{E}-06$ & $1.35 \mathrm{E}-05$ \\
\hline Ru-103 & $8.35 \mathrm{E}-06$ & & $8.35 \mathrm{E}-06$ & $1.54 \mathrm{E}-02$ \\
\hline Ce-144 & $4.00 \mathrm{E}-03$ & & $4.00 \mathrm{E}-03$ & $3.66 \mathrm{E}-02$ \\
\hline La-140 & $7.63 \mathrm{E}-06$ & & $7.63 \mathrm{E}-06$ & $4.38 \mathrm{E}-04$ \\
\hline $\mathrm{Pu}-239$ & 4.40E-05 & & $4.40 \mathrm{E}-05$ & $5.84 \mathrm{E}-04$ \\
\hline Sum & 2.39E-02 & $0.00 E+00$ & $2.39 \mathrm{E}-02$ & $1.30 \mathrm{E}+00$ \\
\hline TOTAL & \multicolumn{2}{|c|}{$2.39 \mathrm{E}-02$} & \multicolumn{2}{|c|}{$1.32 \mathrm{E}+00$} \\
\hline Limits (rem) & \multicolumn{4}{|c|}{25} \\
\hline
\end{tabular}


Table C-3. $600 \mathrm{MW}(\mathrm{t})$ prismatic $700^{\circ} \mathrm{C}$ ROT — break in HPB — Cases C and D- $400 \mathrm{~m}$ from release (rem).

\begin{tabular}{|c|c|c|c|c|}
\hline \multirow[t]{2}{*}{ Nuclide } & \multicolumn{2}{|c|}{$\begin{array}{l}\text { CASE C/Inh, grndshine, } \\
\text { cldshine/TEDE }\end{array}$} & \multicolumn{2}{|c|}{$\begin{array}{l}\text { CASE D/Inh, grndshine, } \\
\text { cldshine/Thyroid }\end{array}$} \\
\hline & Short & Long & Short & Long \\
\hline Xe-133 & $7.46 \mathrm{E}-06$ & $1.22 \mathrm{E}-05$ & & \\
\hline $\mathrm{Kr}-85$ & 3.01E-09 & $7.06 \mathrm{E}-09$ & & \\
\hline $\mathrm{Kr}-88$ & $2.80 \mathrm{E}-04$ & $8.08 \mathrm{E}-10$ & & \\
\hline $\mathrm{I}-131$ & $9.98 \mathrm{E}-05$ & $4.23 \mathrm{E}-03$ & $3.16 \mathrm{E}-03$ & $1.35 \mathrm{E}-01$ \\
\hline $\mathrm{I}-133$ & $3.46 \mathrm{E}-05$ & $2.43 \mathrm{E}-04$ & $9.38 \mathrm{E}-04$ & $6.59 \mathrm{E}-03$ \\
\hline Te-132 & 5.82E-05 & $1.83 \mathrm{E}-03$ & $9.36 \mathrm{E}-04$ & $2.98 \mathrm{E}-02$ \\
\hline Cs-137 & $2.24 \mathrm{E}-04$ & $2.51 \mathrm{E}-04$ & & \\
\hline Cs-134 & $5.21 \mathrm{E}-05$ & $4.16 \mathrm{E}-04$ & & \\
\hline Sr-90 & $1.99 \mathrm{E}-05$ & $2.45 \mathrm{E}-03$ & & \\
\hline $\mathrm{Ag}-110 \mathrm{~m}$ & $1.85 \mathrm{E}-04$ & $4.36 \mathrm{E}-03$ & & \\
\hline Ag-111 & $2.58 \mathrm{E}-04$ & $2.17 \mathrm{E}-02$ & & \\
\hline $\mathrm{Sb}-125$ & $1.41 \mathrm{E}-07$ & $3.80 \mathrm{E}-07$ & & \\
\hline $\mathrm{Ru}-103$ & $4.52 \mathrm{E}-07$ & $4.30 \mathrm{E}-04$ & & \\
\hline $\mathrm{Ce}-144$ & $1.87 \mathrm{E}-04$ & $1.05 \mathrm{E}-03$ & & \\
\hline La-140 & $3.54 \mathrm{E}-07$ & $1.14 \mathrm{E}-05$ & & \\
\hline $\mathrm{Pu}-239$ & $3.22 \mathrm{E}-06$ & $1.73 \mathrm{E}-05$ & & \\
\hline Sum & $1.41 \mathrm{E}-03$ & $3.70 \mathrm{E}-02$ & $5.04 \mathrm{E}-03$ & $1.71 \mathrm{E}-01$ \\
\hline TOTAL & \multicolumn{2}{|c|}{$3.84 \mathrm{E}-02$} & \multicolumn{2}{|c|}{$1.76 \mathrm{E}-01$} \\
\hline Limits (rem) & \multicolumn{2}{|c|}{1} & \multicolumn{2}{|c|}{5} \\
\hline
\end{tabular}


Table C-4. $600 \mathrm{MW}(\mathrm{t})$ prismatic $700^{\circ} \mathrm{C}$ ROT_-break in HPB — Cases E and F, infant and adult $-400 \mathrm{~m}$ from release (rem).

\begin{tabular}{|c|c|c|c|c|c|c|c|c|}
\hline \multirow[t]{2}{*}{ Nuclide } & \multicolumn{2}{|c|}{$\begin{array}{l}\text { CASE E/Ingestion - milk/ } \\
\text { EDE (infant) }\end{array}$} & \multicolumn{2}{|c|}{$\begin{array}{l}\text { CASE F/Ingestion - milk/ } \\
\text { Thyroid (infant) }\end{array}$} & \multicolumn{2}{|c|}{$\begin{array}{l}\text { CASE E/Ingestion - milk/ } \\
\text { EDE (adult) }\end{array}$} & \multicolumn{2}{|c|}{$\begin{array}{l}\text { CASE F/Ingestion - milk/ } \\
\text { Thyroid (adult) }\end{array}$} \\
\hline & Short & Long & Short & Long & Short & Long & Short & Long \\
\hline Xe-133 & - & - & - & - & - & - & - & - \\
\hline $\mathrm{Kr}-85$ & - & - & - & - & - & - & - & - \\
\hline $\mathrm{Kr}-88$ & - & - & - & - & - & - & - & - \\
\hline $\mathrm{I}-131$ & $3.74 \mathrm{E}-03$ & $1.53 \mathrm{E}-01$ & $7.46 \mathrm{E}-02$ & $3.05 \mathrm{E}+00$ & $2.32 \mathrm{E}-04$ & $9.53 \mathrm{E}-03$ & $7.70 \mathrm{E}-03$ & $3.15 \mathrm{E}-01$ \\
\hline $\mathrm{I}-133$ & $2.90 \mathrm{E}-04$ & $1.94 \mathrm{E}-03$ & $5.63 \mathrm{E}-03$ & $3.77 \mathrm{E}-02$ & $1.30 \mathrm{E}-05$ & $8.75 \mathrm{E}-05$ & $4.24 \mathrm{E}-04$ & $2.85 \mathrm{E}-03$ \\
\hline Te-132 & $1.36 \mathrm{E}-05$ & $4.08 \mathrm{E}-04$ & $1.84 \mathrm{E}-04$ & $5.52 \mathrm{E}-03$ & $5.67 \mathrm{E}-07$ & $1.70 \mathrm{E}-05$ & $1.33 \mathrm{E}-05$ & $3.98 \mathrm{E}-04$ \\
\hline Cs-137 & $2.97 \mathrm{E}-03$ & $3.27 \mathrm{E}-03$ & $2.66 \mathrm{E}-03$ & $2.93 \mathrm{E}-03$ & $1.51 \mathrm{E}-03$ & $1.66 \mathrm{E}-03$ & $1.41 \mathrm{E}-03$ & $1.55 \mathrm{E}-03$ \\
\hline Cs-134 & $5.51 \mathrm{E}-04$ & 4.32E-03 & $5.45 \mathrm{E}-04$ & $4.28 \mathrm{E}-03$ & $3.35 \mathrm{E}-04$ & $2.63 \mathrm{E}-03$ & $2.98 \mathrm{E}-04$ & $2.34 \mathrm{E}-03$ \\
\hline Sr-90 & $7.53 \mathrm{E}-05$ & $8.86 \mathrm{E}-03$ & $3.92 \mathrm{E}-06$ & 4.61E-04 & $1.02 \mathrm{E}-05$ & $1.19 \mathrm{E}-03$ & $3.98 \mathrm{E}-07$ & $4.68 \mathrm{E}-05$ \\
\hline $\mathrm{Ag}-110 \mathrm{~m}$ & $2.14 \mathrm{E}-03$ & $4.93 \mathrm{E}-02$ & $5.76 \mathrm{E}-04$ & $1.33 \mathrm{E}-02$ & $2.05 \mathrm{E}-04$ & $4.75 \mathrm{E}-03$ & $1.27 \mathrm{E}-05$ & $2.94 \mathrm{E}-04$ \\
\hline Ag-111 & 7.63E-03 & $6.17 \mathrm{E}-01$ & $2.07 \mathrm{E}-04$ & $1.67 \mathrm{E}-02$ & $5.80 \mathrm{E}-04$ & $4.69 \mathrm{E}-02$ & $3.17 \mathrm{E}-06$ & $2.56 \mathrm{E}-04$ \\
\hline $\mathrm{Sb}-125$ & $1.90 \mathrm{E}-07$ & $5.34 \mathrm{E}-07$ & $1.99 \mathrm{E}-07$ & $5.60 \mathrm{E}-07$ & $1.12 \mathrm{E}-08$ & $3.12 \mathrm{E}-08$ & $5.60 \mathrm{E}-10$ & $1.57 \mathrm{E}-09$ \\
\hline Ru-103 & $2.60 \mathrm{E}-10$ & $2.45 \mathrm{E}-07$ & $4.05 \mathrm{E}-11$ & $3.81 \mathrm{E}-08$ & $2.39 \mathrm{E}-11$ & $2.26 \mathrm{E}-08$ & $1.81 \mathrm{E}-12$ & $1.70 \mathrm{E}-09$ \\
\hline Ce-144 & $1.47 \mathrm{E}-06$ & $7.87 \mathrm{E}-06$ & $1.87 \mathrm{E}-08$ & $9.98 \mathrm{E}-08$ & $9.96 \mathrm{E}-08$ & $5.33 \mathrm{E}-07$ & $9.00 \mathrm{E}-11$ & $4.81 \mathrm{E}-10$ \\
\hline La-140 & $3.11 \mathrm{E}-09$ & $9.87 \mathrm{E}-08$ & $1.99 \mathrm{E}-11$ & $6.31 \mathrm{E}-10$ & $2.87 \mathrm{E}-10$ & $9.11 \mathrm{E}-09$ & $8.09 \mathrm{E}-13$ & $2.56 \mathrm{E}-11$ \\
\hline $\mathrm{Pu}-239$ & $1.10 \mathrm{E}-11$ & $5.65 \mathrm{E}-11$ & $1.44 \mathrm{E}-12$ & $7.42 \mathrm{E}-12$ & $2.91 \mathrm{E}-14$ & $1.50 \mathrm{E}-13$ & $1.56 \mathrm{E}-19$ & $8.05 \mathrm{E}-19$ \\
\hline Sum & $1.74 \mathrm{E}-02$ & 8.39E-01 & $8.44 \mathrm{E}-02$ & $3.13 E+00$ & $2.89 \mathrm{E}-03$ & $6.68 \mathrm{E}-02$ & $9.86 \mathrm{E}-03$ & 3.22E-01 \\
\hline TOTAL & \multicolumn{2}{|c|}{$8.56 \mathrm{E}-01$} & \multicolumn{2}{|c|}{$3.21 \mathrm{E}+00$} & \multicolumn{2}{|c|}{$6.97 \mathrm{E}-02$} & \multicolumn{2}{|c|}{ 3.32E-01 } \\
\hline Limits (rem) & \multicolumn{2}{|c|}{0.5} & \multicolumn{2}{|c|}{1.5} & \multicolumn{2}{|c|}{0.5} & \multicolumn{2}{|c|}{1.5} \\
\hline
\end{tabular}


Table C-5. $600 \mathrm{MW}(\mathrm{t})$ prismatic $700^{\circ} \mathrm{C}$ ROT-break in HPB-Cases E and F, infant and adult - $800 \mathrm{~m}$ from release (rem).

\begin{tabular}{|c|c|c|c|c|c|c|c|c|}
\hline \multirow[t]{2}{*}{ Nuclide } & \multicolumn{2}{|c|}{$\begin{array}{c}\text { CASE E/Ingestion - milk/ } \\
\text { EDE (infant) }\end{array}$} & \multicolumn{2}{|c|}{$\begin{array}{l}\text { CASE F/Ingestion - milk/ } \\
\text { Thyroid (infant) }\end{array}$} & \multicolumn{2}{|c|}{$\begin{array}{l}\text { CASE E/Ingestion - milk/ } \\
\text { EDE (adult) }\end{array}$} & \multicolumn{2}{|c|}{$\begin{array}{c}\text { CASE F/Ingestion - milk/ } \\
\text { Thyroid (adult) }\end{array}$} \\
\hline & Short & Long & Short & Long & Short & Long & Short & Long \\
\hline Xe-133 & - & - & - & - & - & - & - & - \\
\hline $\mathrm{Kr}-85$ & - & - & - & - & - & - & - & - \\
\hline $\mathrm{Kr}-88$ & - & - & - & - & - & - & - & - \\
\hline I-131 & $1.38 \mathrm{E}-03$ & $5.71 \mathrm{E}-02$ & $2.74 \mathrm{E}-02$ & $1.14 \mathrm{E}+00$ & $8.56 \mathrm{E}-05$ & $3.55 \mathrm{E}-03$ & $2.82 \mathrm{E}-03$ & $1.17 \mathrm{E}-01$ \\
\hline I-133 & $1.06 \mathrm{E}-04$ & $7.20 \mathrm{E}-04$ & $2.06 \mathrm{E}-03$ & $1.40 \mathrm{E}-02$ & $4.76 \mathrm{E}-06$ & $3.24 \mathrm{E}-05$ & $1.55 \mathrm{E}-04$ & $1.05 \mathrm{E}-03$ \\
\hline Te-132 & $5.00 \mathrm{E}-06$ & $1.52 \mathrm{E}-04$ & $6.78 \mathrm{E}-05$ & $2.06 \mathrm{E}-03$ & $2.08 \mathrm{E}-07$ & $6.33 \mathrm{E}-06$ & 4.87E-06 & $1.48 \mathrm{E}-04$ \\
\hline Cs-137 & $1.09 \mathrm{E}-03$ & $1.22 \mathrm{E}-03$ & $9.76 \mathrm{E}-04$ & $1.09 \mathrm{E}-03$ & $5.55 \mathrm{E}-04$ & $6.16 \mathrm{E}-04$ & $5.17 \mathrm{E}-04$ & $5.76 \mathrm{E}-04$ \\
\hline Cs-134 & $2.03 \mathrm{E}-04$ & $1.61 \mathrm{E}-03$ & $2.00 \mathrm{E}-04$ & $1.59 \mathrm{E}-03$ & $1.23 \mathrm{E}-04$ & $9.78 \mathrm{E}-04$ & $1.10 \mathrm{E}-04$ & $8.71 \mathrm{E}-04$ \\
\hline Sr-90 & $2.77 \mathrm{E}-05$ & $3.29 \mathrm{E}-03$ & $1.44 \mathrm{E}-06$ & $1.71 \mathrm{E}-04$ & $3.72 \mathrm{E}-06$ & 4.42E-04 & $1.46 \mathrm{E}-07$ & $1.73 \mathrm{E}-05$ \\
\hline Ag-110m & $7.84 \mathrm{E}-04$ & $1.84 \mathrm{E}-02$ & $2.11 \mathrm{E}-04$ & $4.93 \mathrm{E}-03$ & $7.55 \mathrm{E}-05$ & $1.76 \mathrm{E}-03$ & $4.67 \mathrm{E}-06$ & $1.09 \mathrm{E}-04$ \\
\hline Ag-111 & $2.81 \mathrm{E}-03$ & $2.30 \mathrm{E}-01$ & $7.58 \mathrm{E}-05$ & $6.23 \mathrm{E}-03$ & $2.13 \mathrm{E}-04$ & $1.75 \mathrm{E}-02$ & $1.16 \mathrm{E}-06$ & $9.56 \mathrm{E}-05$ \\
\hline $\mathrm{Sb}-125$ & $6.96 \mathrm{E}-08$ & $1.97 \mathrm{E}-07$ & 7.28E-08 & $2.06 \mathrm{E}-07$ & 4.07E-09 & $1.16 \mathrm{E}-08$ & $2.05 \mathrm{E}-10$ & $5.81 \mathrm{E}-10$ \\
\hline Ru-103 & $9.55 \mathrm{E}-11$ & $9.14 \mathrm{E}-08$ & $1.49 \mathrm{E}-11$ & $1.42 \mathrm{E}-08$ & $8.77 \mathrm{E}-12$ & 8.39E-09 & $6.64 \mathrm{E}-13$ & $6.35 \mathrm{E}-10$ \\
\hline $\mathrm{Ce}-144$ & $5.39 \mathrm{E}-07$ & $2.92 \mathrm{E}-06$ & $6.82 \mathrm{E}-09$ & $3.71 \mathrm{E}-08$ & $3.66 \mathrm{E}-08$ & $1.98 \mathrm{E}-07$ & $3.30 \mathrm{E}-11$ & $1.79 \mathrm{E}-10$ \\
\hline La-140 & $1.14 \mathrm{E}-09$ & $3.67 \mathrm{E}-08$ & $7.29 \mathrm{E}-12$ & $2.35 \mathrm{E}-10$ & $1.06 \mathrm{E}-10$ & $3.41 \mathrm{E}-09$ & $2.96 \mathrm{E}-13$ & $9.57 \mathrm{E}-12$ \\
\hline Pu-239 & $4.02 \mathrm{E}-12$ & $2.10 \mathrm{E}-11$ & $5.27 \mathrm{E}-13$ & $2.76 \mathrm{E}-12$ & $1.07 \mathrm{E}-14$ & $5.57 \mathrm{E}-14$ & $5.71 \mathrm{E}-20$ & $3.00 \mathrm{E}-19$ \\
\hline Sum & $6.41 \mathrm{E}-03$ & 3.13E-01 & $3.10 \mathrm{E}-02$ & $1.17 E+00$ & $1.06 \mathrm{E}-03$ & $2.49 \mathrm{E}-02$ & $3.62 \mathrm{E}-03$ & $1.20 \mathrm{E}-01$ \\
\hline TOTAL & \multicolumn{2}{|c|}{ 3.19E-01 } & \multicolumn{2}{|c|}{$1.20 \mathrm{E}+00$} & \multicolumn{2}{|c|}{$2.60 \mathrm{E}-02$} & \multicolumn{2}{|c|}{$1.24 \mathrm{E}-01$} \\
\hline Limits (rem) & \multicolumn{2}{|c|}{0.5} & \multicolumn{2}{|c|}{1.5} & \multicolumn{2}{|c|}{0.5} & \multicolumn{2}{|c|}{1.5} \\
\hline
\end{tabular}


Table C-6. $600 \mathrm{MW}(\mathrm{t})$ prismatic $700^{\circ} \mathrm{C}$ ROT_-break in HPB — Cases E and F, infant and adult- $1600 \mathrm{~m}$ from release (rem).

\begin{tabular}{|c|c|c|c|c|c|c|c|c|}
\hline \multirow[t]{2}{*}{ Nuclide } & \multicolumn{2}{|c|}{$\begin{array}{l}\text { CASE E/Ingestion - milk/ } \\
\text { EDE (infant) }\end{array}$} & \multicolumn{2}{|c|}{$\begin{array}{l}\text { CASE F/Ingestion - milk/ } \\
\text { Thyroid (infant) }\end{array}$} & \multicolumn{2}{|c|}{$\begin{array}{l}\text { CASE E/Ingestion - milk/ EDE } \\
\text { (adult) }\end{array}$} & \multicolumn{2}{|c|}{$\begin{array}{l}\text { CASE F/Ingestion - milk/ } \\
\text { Thyroid (adult) }\end{array}$} \\
\hline & Short & Long & Short & Long & Short & Long & Short & Long \\
\hline Xe-133 & - & - & - & - & - & - & - & - \\
\hline $\mathrm{Kr}-85$ & - & - & - & - & - & - & - & - \\
\hline Kr- 88 & - & - & - & - & - & - & - & - \\
\hline I-131 & $5.02 \mathrm{E}-04$ & $2.16 \mathrm{E}-02$ & $9.99 \mathrm{E}-03$ & 4.30E-01 & $3.12 \mathrm{E}-05$ & $1.34 \mathrm{E}-03$ & $1.03 \mathrm{E}-03$ & 4.44E-02 \\
\hline I-133 & $3.83 \mathrm{E}-05$ & $2.69 \mathrm{E}-04$ & $7.46 \mathrm{E}-04$ & $5.27 \mathrm{E}-03$ & $1.73 \mathrm{E}-06$ & $1.22 \mathrm{E}-05$ & $5.60 \mathrm{E}-05$ & $3.95 \mathrm{E}-04$ \\
\hline Te-132 & $1.82 \mathrm{E}-06$ & $5.74 \mathrm{E}-05$ & $2.48 \mathrm{E}-05$ & $7.74 \mathrm{E}-04$ & $7.58 \mathrm{E}-08$ & 2.39E-06 & $1.77 \mathrm{E}-06$ & $5.60 \mathrm{E}-05$ \\
\hline Cs-137 & $3.97 \mathrm{E}-04$ & $4.60 \mathrm{E}-04$ & $3.56 \mathrm{E}-04$ & $4.11 \mathrm{E}-04$ & $2.02 \mathrm{E}-04$ & $2.33 \mathrm{E}-04$ & $1.89 \mathrm{E}-04$ & $2.18 \mathrm{E}-04$ \\
\hline Cs-134 & $7.36 \mathrm{E}-05$ & $6.07 \mathrm{E}-04$ & $7.31 \mathrm{E}-05$ & $6.00 \mathrm{E}-04$ & 4.50E-05 & $3.70 \mathrm{E}-04$ & $4.00 \mathrm{E}-05$ & $3.29 \mathrm{E}-04$ \\
\hline $\mathrm{Sr}-90$ & $1.01 \mathrm{E}-05$ & $1.24 \mathrm{E}-03$ & $5.25 \mathrm{E}-07$ & $6.45 \mathrm{E}-05$ & $1.36 \mathrm{E}-06$ & $1.67 \mathrm{E}-04$ & $5.34 \mathrm{E}-08$ & $6.55 \mathrm{E}-06$ \\
\hline Ag-110m & $2.85 \mathrm{E}-04$ & $6.91 \mathrm{E}-03$ & $7.69 \mathrm{E}-05$ & $1.86 \mathrm{E}-03$ & $2.75 \mathrm{E}-05$ & $6.66 \mathrm{E}-04$ & $1.70 \mathrm{E}-06$ & 4.13E-05 \\
\hline Ag-111 & $1.02 \mathrm{E}-03$ & $8.70 \mathrm{E}-02$ & $2.76 \mathrm{E}-05$ & $2.36 \mathrm{E}-03$ & 7.79E-05 & $6.62 \mathrm{E}-03$ & $4.25 \mathrm{E}-07$ & $3.61 \mathrm{E}-05$ \\
\hline $\mathrm{Sb}-125$ & $2.52 \mathrm{E}-08$ & $7.43 \mathrm{E}-08$ & $2.65 \mathrm{E}-08$ & 7.69E-08 & $1.48 \mathrm{E}-09$ & 4.34E-09 & 7.47E-11 & $2.18 \mathrm{E}-10$ \\
\hline Ru-103 & $3.49 \mathrm{E}-11$ & $3.45 \mathrm{E}-08$ & $5.43 \mathrm{E}-12$ & $5.37 \mathrm{E}-09$ & $3.21 \mathrm{E}-12$ & $3.18 \mathrm{E}-09$ & $2.43 \mathrm{E}-13$ & $2.39 \mathrm{E}-10$ \\
\hline Ce-144 & $1.96 \mathrm{E}-07$ & $1.10 \mathrm{E}-06$ & $2.49 \mathrm{E}-09$ & $1.40 \mathrm{E}-08$ & $1.33 \mathrm{E}-08$ & $7.47 \mathrm{E}-08$ & $1.20 \mathrm{E}-11$ & $6.74 \mathrm{E}-11$ \\
\hline La-140 & 4.14E-10 & $1.38 \mathrm{E}-08$ & $2.65 \mathrm{E}-12$ & $8.88 \mathrm{E}-11$ & $3.84 \mathrm{E}-11$ & $1.28 \mathrm{E}-09$ & $1.08 \mathrm{E}-13$ & $3.60 \mathrm{E}-12$ \\
\hline $\mathrm{Pu}-239$ & $1.46 \mathrm{E}-12$ & $7.89 \mathrm{E}-12$ & $1.92 \mathrm{E}-13$ & $1.04 \mathrm{E}-12$ & $3.88 \mathrm{E}-15$ & $2.10 \mathrm{E}-14$ & $2.08 \mathrm{E}-20$ & $1.12 \mathrm{E}-19$ \\
\hline Sum & $2.33 \mathrm{E}-03$ & 1.18E-01 & $1.13 \mathrm{E}-02$ & $4.41 \mathrm{E}-01$ & 3.87E-04 & $9.42 \mathrm{E}-03$ & $1.32 \mathrm{E}-03$ & $4.54 \mathrm{E}-02$ \\
\hline TOTAL & \multicolumn{2}{|c|}{$1.20 \mathrm{E}-01$} & \multicolumn{2}{|c|}{$4.52 \mathrm{E}-01$} & \multicolumn{2}{|c|}{$9.80 \mathrm{E}-03$} & \multicolumn{2}{|c|}{$4.68 \mathrm{E}-02$} \\
\hline Limits (rem) & \multicolumn{2}{|c|}{0.5} & \multicolumn{2}{|c|}{1.5} & \multicolumn{2}{|c|}{0.5} & \multicolumn{2}{|c|}{1.5} \\
\hline
\end{tabular}




\section{C-1.2 Accident Scenario: Water Ingress Event}

\section{C-1.2.1 Source Term}

Table C-7. $600 \mathrm{MW}(\mathrm{t})$ prismatic $700^{\circ} \mathrm{C} \mathrm{ROT}$-water ingress - source term (curies).

\begin{tabular}{|c|c|c|c|c|c|c|c|c|}
\hline \multirow{2}{*}{ Nuclide } & \multicolumn{4}{|c|}{ Release to Environment Short Term } & \multicolumn{4}{|c|}{ Release to Environment Long Term } \\
\hline & DBA & $50 \%$ & Mean & $95 \%$ & DBA & $50 \%$ & Mean & $95 \%$ \\
\hline Xe-133 & $3.99 \mathrm{E}+01$ & $3.99 \mathrm{E}+01$ & $3.99 \mathrm{E}+01$ & $3.99 \mathrm{E}+01$ & $4.42 \mathrm{E}+02$ & $1.08 \mathrm{E}+02$ & $1.54 \mathrm{E}+02$ & $4.42 \mathrm{E}+02$ \\
\hline $\mathrm{Kr}-85$ & $2.10 \mathrm{E}-01$ & $2.10 \mathrm{E}-01$ & $2.10 \mathrm{E}-01$ & $2.10 \mathrm{E}-01$ & $3.08 \mathrm{E}+00$ & $7.31 \mathrm{E}-01$ & $1.06 \mathrm{E}+00$ & $3.08 \mathrm{E}+00$ \\
\hline $\mathrm{Kr}-88$ & $2.03 \mathrm{E}+01$ & $2.03 \mathrm{E}+01$ & $2.03 \mathrm{E}+01$ & $2.03 \mathrm{E}+01$ & $1.25 \mathrm{E}-03$ & $3.05 \mathrm{E}-04$ & 4.32E-04 & $1.25 \mathrm{E}-03$ \\
\hline $\mathrm{I}-131$ & $2.21 \mathrm{E}+01$ & $1.10 \mathrm{E}+00$ & $1.90 \mathrm{E}+00$ & $6.56 \mathrm{E}+00$ & $5.62 \mathrm{E}+02$ & $3.16 \mathrm{E}+00$ & $6.90 \mathrm{E}+00$ & $2.48 \mathrm{E}+01$ \\
\hline $\mathrm{I}-133$ & $4.00 \mathrm{E}+01$ & $2.01 \mathrm{E}+00$ & $3.36 \mathrm{E}+00$ & $1.12 \mathrm{E}+01$ & $2.32 \mathrm{E}+02$ & $1.31 \mathrm{E}+00$ & $2.85 \mathrm{E}+00$ & $1.02 \mathrm{E}+01$ \\
\hline Te-132 & $2.99 \mathrm{E}+01$ & $1.48 \mathrm{E}+00$ & $2.54 \mathrm{E}+00$ & $8.52 \mathrm{E}+00$ & $5.94 \mathrm{E}+02$ & $3.29 \mathrm{E}+00$ & $7.00 \mathrm{E}+00$ & $2.54 \mathrm{E}+01$ \\
\hline Cs-137 & $4.84 \mathrm{E}+01$ & $2.37 \mathrm{E}+00$ & $4.06 \mathrm{E}+00$ & $1.35 \mathrm{E}+01$ & $6.53 \mathrm{E}+01$ & $2.59 \mathrm{E}-01$ & $7.06 \mathrm{E}-01$ & $2.67 \mathrm{E}+00$ \\
\hline Cs-134 & $7.55 \mathrm{E}+00$ & $3.77 \mathrm{E}-01$ & $6.36 \mathrm{E}-01$ & $2.16 \mathrm{E}+00$ & $7.41 \mathrm{E}+01$ & $2.92 \mathrm{E}-01$ & $7.81 \mathrm{E}-01$ & $3.09 \mathrm{E}+00$ \\
\hline Sr-90 & $6.26 \mathrm{E}-01$ & $3.12 \mathrm{E}-02$ & $5.28 \mathrm{E}-02$ & $1.72 \mathrm{E}-01$ & $1.04 \mathrm{E}+02$ & $3.62 \mathrm{E}-01$ & $9.59 \mathrm{E}-01$ & $3.58 \mathrm{E}+00$ \\
\hline Ag-110m & $1.52 \mathrm{E}+01$ & $7.60 \mathrm{E}-01$ & $1.30 \mathrm{E}+00$ & $4.31 \mathrm{E}+00$ & $1.71 \mathrm{E}+02$ & 8.89E-01 & $2.01 \mathrm{E}+00$ & $7.33 \mathrm{E}+00$ \\
\hline Ag-111 & $3.17 \mathrm{E}+02$ & $1.57 \mathrm{E}+01$ & $2.65 \mathrm{E}+01$ & $8.81 \mathrm{E}+01$ & $1.42 \mathrm{E}+04$ & $5.59 \mathrm{E}+01$ & $1.53 \mathrm{E}+02$ & $5.60 \mathrm{E}+02$ \\
\hline Sb-125 & $2.98 \mathrm{E}-01$ & $1.51 \mathrm{E}-02$ & $2.52 \mathrm{E}-02$ & $8.35 \mathrm{E}-02$ & 5.69E-01 & $1.95 \mathrm{E}-03$ & $5.52 \mathrm{E}-03$ & $2.17 \mathrm{E}-02$ \\
\hline Ru-103 & $3.20 \mathrm{E}-01$ & $1.57 \mathrm{E}-02$ & $2.66 \mathrm{E}-02$ & 8.79E-02 & $1.48 \mathrm{E}+02$ & $6.91 \mathrm{E}-01$ & $1.69 \mathrm{E}+00$ & $6.42 \mathrm{E}+00$ \\
\hline $\mathrm{Ce}-144$ & $3.96 \mathrm{E}+00$ & $1.98 \mathrm{E}-01$ & $3.33 \mathrm{E}-01$ & $1.08 \mathrm{E}+00$ & $1.01 \mathrm{E}+01$ & $4.82 \mathrm{E}-02$ & $1.13 \mathrm{E}-01$ & $4.08 \mathrm{E}-01$ \\
\hline La-140 & $2.95 \mathrm{E}-01$ & $1.45 \mathrm{E}-02$ & $2.46 \mathrm{E}-02$ & $8.36 \mathrm{E}-02$ & $6.10 \mathrm{E}+00$ & $2.81 \mathrm{E}-02$ & $6.66 \mathrm{E}-02$ & $2.44 \mathrm{E}-01$ \\
\hline $\mathrm{Pu}-239$ & $7.53 \mathrm{E}-05$ & $3.70 \mathrm{E}-06$ & $6.23 \mathrm{E}-06$ & $2.09 \mathrm{E}-05$ & $1.89 \mathrm{E}-04$ & $9.07 \mathrm{E}-07$ & $2.13 \mathrm{E}-06$ & $7.80 \mathrm{E}-06$ \\
\hline
\end{tabular}




\section{C-1.2.2 Doses}

Table C-8. $600 \mathrm{MW}(\mathrm{t})$ prismatic $700^{\circ} \mathrm{C}$ ROT_water ingress - Cases A and B- $400 \mathrm{~m}$ from release (rem).

\begin{tabular}{|c|c|c|c|c|}
\hline \multirow[t]{2}{*}{ Nuclide } & \multicolumn{2}{|c|}{$\begin{array}{c}\text { Case A/EAB } \\
(400 \mathrm{~m}) / \mathrm{TEDE}\end{array}$} & \multicolumn{2}{|c|}{$\begin{array}{c}\text { Case B/LPZ } \\
(400 \mathrm{~m}) / \mathrm{TEDE}\end{array}$} \\
\hline & Short & Long & Short & Long \\
\hline Xe-133 & $1.86 \mathrm{E}-05$ & & $1.86 \mathrm{E}-05$ & $1.40 \mathrm{E}-04$ \\
\hline $\mathrm{Kr}-85$ & 8.22E-09 & & $8.22 \mathrm{E}-09$ & $8.06 \mathrm{E}-08$ \\
\hline $\mathrm{Kr}-88$ & $6.20 \mathrm{E}-04$ & & $6.20 \mathrm{E}-04$ & $1.27 \mathrm{E}-08$ \\
\hline $\mathrm{I}-131$ & 4.42E-02 & & 4.42E-02 & $6.41 \mathrm{E}-01$ \\
\hline $\mathrm{I}-133$ & $1.23 \mathrm{E}-02$ & & $1.23 \mathrm{E}-02$ & $3.57 \mathrm{E}-02$ \\
\hline Тe-132 & 2.23E-02 & & $2.23 \mathrm{E}-02$ & $3.07 \mathrm{E}-01$ \\
\hline Cs-137 & $9.78 \mathrm{E}-02$ & & $9.78 \mathrm{E}-02$ & 7.84E-02 \\
\hline Cs-134 & $2.28 \mathrm{E}-02$ & & $2.28 \mathrm{E}-02$ & $1.44 \mathrm{E}-01$ \\
\hline Sr-90 & $6.39 \mathrm{E}-03$ & & 6.39E-03 & $9.29 \mathrm{E}-01$ \\
\hline Ag-110m & $7.66 \mathrm{E}-02$ & & $7.66 \mathrm{E}-02$ & $5.48 \mathrm{E}-01$ \\
\hline Ag-111 & $9.60 \mathrm{E}-02$ & & $9.60 \mathrm{E}-02$ & $3.10 \mathrm{E}+00$ \\
\hline $\mathrm{Sb}-125$ & $6.21 \mathrm{E}-05$ & & $6.21 \mathrm{E}-05$ & $7.00 \mathrm{E}-05$ \\
\hline Ru-103 & $1.65 \mathrm{E}-04$ & & $1.65 \mathrm{E}-04$ & $5.39 \mathrm{E}-02$ \\
\hline Ce-144 & 7.93E-02 & & 7.93E-02 & $1.31 \mathrm{E}-01$ \\
\hline La-140 & $1.52 \mathrm{E}-04$ & & $1.52 \mathrm{E}-04$ & $1.66 \mathrm{E}-03$ \\
\hline $\mathrm{Pu}-239$ & $8.66 \mathrm{E}-04$ & & $8.66 \mathrm{E}-04$ & $2.08 \mathrm{E}-03$ \\
\hline Sum & $4.60 \mathrm{E}-01$ & $0.00 E+00$ & $4.60 \mathrm{E}-01$ & $5.97 \mathrm{E}+00$ \\
\hline TOTAL & \multicolumn{2}{|c|}{$4.60 \mathrm{E}-01$} & \multicolumn{2}{|c|}{$6.43 E+00$} \\
\hline Limits (rem) & \multicolumn{4}{|c|}{ 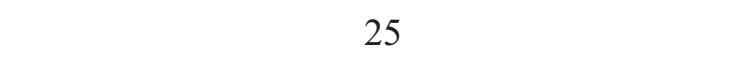 } \\
\hline
\end{tabular}


Table C-9. $600 \mathrm{MW}(\mathrm{t})$ prismatic $700^{\circ} \mathrm{C}$ ROT_-water ingress - Cases C and D-400 $\mathrm{m}$ from release (rem).

\begin{tabular}{|c|c|c|c|c|}
\hline \multirow[t]{2}{*}{ Nuclide } & \multicolumn{2}{|c|}{$\begin{array}{l}\text { CASE C/Inh, grndshine, } \\
\text { cldshine/TEDE }\end{array}$} & \multicolumn{2}{|c|}{$\begin{array}{l}\text { CASE D/Inh, grndshine, } \\
\text { cldshine/Thyroid }\end{array}$} \\
\hline & Short & Long & Short & Long \\
\hline Xe-133 & $7.46 \mathrm{E}-06$ & $2.93 \mathrm{E}-05$ & & \\
\hline $\mathrm{Kr}-85$ & 3.01E-09 & $1.66 \mathrm{E}-08$ & & \\
\hline $\mathrm{Kr}-88$ & $2.76 \mathrm{E}-04$ & $1.91 \mathrm{E}-09$ & & \\
\hline $\mathrm{I}-131$ & $1.18 \mathrm{E}-03$ & $4.78 \mathrm{E}-03$ & $3.73 \mathrm{E}-02$ & $1.53 \mathrm{E}-01$ \\
\hline I-133 & $4.00 \mathrm{E}-04$ & $2.63 \mathrm{E}-04$ & $1.09 \mathrm{E}-02$ & $7.12 \mathrm{E}-03$ \\
\hline Te-132 & $6.79 \mathrm{E}-04$ & $1.97 \mathrm{E}-03$ & $1.09 \mathrm{E}-02$ & $3.21 \mathrm{E}-02$ \\
\hline Cs-137 & $2.66 \mathrm{E}-03$ & $5.36 \mathrm{E}-04$ & & \\
\hline Cs-134 & $5.99 \mathrm{E}-04$ & $8.51 \mathrm{E}-04$ & & \\
\hline Sr-90 & $2.30 \mathrm{E}-04$ & $4.99 \mathrm{E}-03$ & & \\
\hline $\mathrm{Ag}-110 \mathrm{~m}$ & $2.13 \mathrm{E}-03$ & $3.81 \mathrm{E}-03$ & & \\
\hline Ag-111 & $3.00 \mathrm{E}-03$ & $1.93 \mathrm{E}-02$ & & \\
\hline $\mathrm{Sb}-125$ & $1.68 \mathrm{E}-06$ & $4.01 \mathrm{E}-07$ & & \\
\hline Ru-103 & $5.14 \mathrm{E}-06$ & $3.70 \mathrm{E}-04$ & & \\
\hline $\mathrm{Ce}-144$ & $2.27 \mathrm{E}-03$ & $9.08 \mathrm{E}-04$ & & \\
\hline La-140 & $4.03 \mathrm{E}-06$ & $9.93 \mathrm{E}-06$ & & \\
\hline $\mathrm{Pu}-239$ & $3.49 \mathrm{E}-05$ & $1.42 \mathrm{E}-05$ & & \\
\hline Sum & $1.35 \mathrm{E}-02$ & $3.78 \mathrm{E}-02$ & $5.91 \mathrm{E}-02$ & $1.92 \mathrm{E}-01$ \\
\hline TOTAL & \multicolumn{2}{|c|}{ 5.13E-02 } & \multicolumn{2}{|c|}{$2.51 \mathrm{E}-01$} \\
\hline Limits (rem) & \multicolumn{2}{|c|}{1} & \multicolumn{2}{|c|}{5} \\
\hline
\end{tabular}


Table C-10. $600 \mathrm{MW}(\mathrm{t})$ prismatic $700^{\circ} \mathrm{C}$ ROT-water ingress-Cases E and F, infant and adult $-400 \mathrm{~m}$ from release (rem).

\begin{tabular}{|c|c|c|c|c|c|c|c|c|}
\hline \multirow[t]{2}{*}{ Nuclide } & \multicolumn{2}{|c|}{$\begin{array}{l}\text { CASE E/Ingestion - milk/ } \\
\text { EDE (infant) }\end{array}$} & \multicolumn{2}{|c|}{$\begin{array}{l}\text { CASE F/Ingestion - milk/ } \\
\text { Thyroid (infant) }\end{array}$} & \multicolumn{2}{|c|}{$\begin{array}{c}\text { CASE E/Ingestion - milk/ } \\
\text { EDE (adult) }\end{array}$} & \multicolumn{2}{|c|}{$\begin{array}{c}\text { CASE F/Ingestion - milk/ } \\
\text { Thyroid (adult) }\end{array}$} \\
\hline & Short & Long & Short & Long & Short & Long & Short & Long \\
\hline Xe-133 & - & - & - & - & - & - & - & - \\
\hline $\mathrm{Kr}-85$ & - & - & - & - & - & - & - & - \\
\hline $\mathrm{Kr}-88$ & - & - & - & - & - & - & - & - \\
\hline I-131 & 4.42E-02 & $1.73 \mathrm{E}-01$ & $8.79 \mathrm{E}-01$ & $3.44 \mathrm{E}+00$ & $2.74 \mathrm{E}-03$ & $1.08 \mathrm{E}-02$ & $9.08 \mathrm{E}-02$ & $3.55 \mathrm{E}-01$ \\
\hline I-133 & $3.35 \mathrm{E}-03$ & $2.10 \mathrm{E}-03$ & $6.53 \mathrm{E}-02$ & 4.07E-02 & $1.51 \mathrm{E}-04$ & $9.45 \mathrm{E}-05$ & 4.91E-03 & 3.07E-03 \\
\hline Te-132 & $1.59 \mathrm{E}-04$ & 4.39E-04 & $2.15 \mathrm{E}-03$ & 5.95E-03 & $6.62 \mathrm{E}-06$ & $1.83 \mathrm{E}-05$ & $1.55 \mathrm{E}-04$ & $4.28 \mathrm{E}-04$ \\
\hline Cs-137 & $3.53 \mathrm{E}-02$ & $6.97 \mathrm{E}-03$ & $3.16 \mathrm{E}-02$ & $6.24 \mathrm{E}-03$ & $1.79 \mathrm{E}-02$ & $3.54 \mathrm{E}-03$ & $1.67 \mathrm{E}-02$ & $3.30 \mathrm{E}-03$ \\
\hline Cs-134 & $6.33 \mathrm{E}-03$ & $8.83 \mathrm{E}-03$ & $6.26 \mathrm{E}-03$ & $8.75 \mathrm{E}-03$ & $3.85 \mathrm{E}-03$ & $5.38 \mathrm{E}-03$ & $3.43 \mathrm{E}-03$ & 4.79E-03 \\
\hline $\mathrm{Sr}-90$ & $8.71 \mathrm{E}-04$ & $1.80 \mathrm{E}-02$ & $4.54 \mathrm{E}-05$ & $9.38 \mathrm{E}-04$ & $1.18 \mathrm{E}-04$ & $2.43 \mathrm{E}-03$ & 4.61E-06 & $9.52 \mathrm{E}-05$ \\
\hline Ag-110m & $2.46 \mathrm{E}-02$ & $4.31 \mathrm{E}-02$ & $6.63 \mathrm{E}-03$ & $1.16 \mathrm{E}-02$ & $2.36 \mathrm{E}-03$ & $4.15 \mathrm{E}-03$ & $1.47 \mathrm{E}-04$ & $2.57 \mathrm{E}-04$ \\
\hline Ag-111 & $8.85 \mathrm{E}-02$ & $5.50 \mathrm{E}-01$ & $2.40 \mathrm{E}-03$ & $1.49 \mathrm{E}-02$ & $6.73 \mathrm{E}-03$ & $4.18 \mathrm{E}-02$ & $3.68 \mathrm{E}-05$ & $2.28 \mathrm{E}-04$ \\
\hline $\mathrm{Sb}-125$ & $2.26 \mathrm{E}-06$ & $5.63 \mathrm{E}-07$ & $2.37 \mathrm{E}-06$ & $5.90 \mathrm{E}-07$ & $1.33 \mathrm{E}-07$ & $3.29 \mathrm{E}-08$ & $6.65 \mathrm{E}-09$ & $1.65 \mathrm{E}-09$ \\
\hline Ru-103 & 2.96E-09 & $2.11 \mathrm{E}-07$ & $4.61 \mathrm{E}-10$ & $3.28 \mathrm{E}-08$ & $2.72 \mathrm{E}-10$ & $1.95 \mathrm{E}-08$ & $2.06 \mathrm{E}-11$ & $1.47 \mathrm{E}-09$ \\
\hline Ce-144 & $1.78 \mathrm{E}-05$ & $6.84 \mathrm{E}-06$ & $2.26 \mathrm{E}-07$ & 8.67E-08 & $1.21 \mathrm{E}-06$ & $4.63 \mathrm{E}-07$ & $1.09 \mathrm{E}-09$ & $4.18 \mathrm{E}-10$ \\
\hline La-140 & $3.54 \mathrm{E}-08$ & $8.59 \mathrm{E}-08$ & $2.26 \mathrm{E}-10$ & $5.50 \mathrm{E}-10$ & $3.27 \mathrm{E}-09$ & 7.93E-09 & $9.21 \mathrm{E}-12$ & $2.23 \mathrm{E}-11$ \\
\hline $\mathrm{Pu}-239$ & $1.19 \mathrm{E}-10$ & $4.63 \mathrm{E}-11$ & $1.56 \mathrm{E}-11$ & $6.08 \mathrm{E}-12$ & $3.16 \mathrm{E}-13$ & $1.23 \mathrm{E}-13$ & $1.69 \mathrm{E}-18$ & $6.59 \mathrm{E}-19$ \\
\hline Sum & 2.03E-01 & 8.02E-01 & $9.94 \mathrm{E}-01$ & $3.53 \mathrm{E}+00$ & $3.39 \mathrm{E}-02$ & $6.82 \mathrm{E}-02$ & 1.16E-01 & $3.68 \mathrm{E}-01$ \\
\hline TOTAL & \multicolumn{2}{|c|}{$1.01 \mathrm{E}+00$} & \multicolumn{2}{|c|}{$4.53 \mathrm{E}+00$} & \multicolumn{2}{|c|}{$1.02 E-01$} & \multicolumn{2}{|c|}{$4.84 \mathrm{E}-01$} \\
\hline Limits (rem) & \multicolumn{2}{|c|}{0.5} & \multicolumn{2}{|c|}{1.5} & \multicolumn{2}{|c|}{0.5} & \multicolumn{2}{|c|}{1.5} \\
\hline
\end{tabular}


Table C-11. $600 \mathrm{MW}(\mathrm{t})$ prismatic $700^{\circ} \mathrm{C}$ ROT - water ingress - Cases E and F, infant and adult — $800 \mathrm{~m}$ from release (rem).

\begin{tabular}{|c|c|c|c|c|c|c|c|c|}
\hline \multirow[t]{2}{*}{ Nuclide } & \multicolumn{2}{|c|}{$\begin{array}{l}\text { CASE E/Ingestion - milk/ } \\
\text { EDE (infant) }\end{array}$} & \multicolumn{2}{|c|}{$\begin{array}{l}\text { CASE F/Ingestion - milk/ } \\
\text { Thyroid (infant) }\end{array}$} & \multicolumn{2}{|c|}{$\begin{array}{c}\text { CASE E/Ingestion - milk/ } \\
\text { EDE (adult) }\end{array}$} & \multicolumn{2}{|c|}{$\begin{array}{l}\text { CASE F/Ingestion - milk/ } \\
\text { Thyroid (adult) }\end{array}$} \\
\hline & Short & Long & Short & Long & Short & Long & Short & Long \\
\hline Xe-133 & - & - & - & - & - & - & - & - \\
\hline $\mathrm{Kr}-85$ & - & - & - & - & - & - & - & - \\
\hline $\mathrm{Kr}-88$ & - & - & - & - & - & - & - & - \\
\hline I-131 & $1.63 \mathrm{E}-02$ & $6.45 \mathrm{E}-02$ & $3.24 \mathrm{E}-01$ & $1.28 \mathrm{E}+00$ & $1.01 \mathrm{E}-03$ & $4.01 \mathrm{E}-03$ & $3.33 \mathrm{E}-02$ & $1.33 \mathrm{E}-01$ \\
\hline I-133 & $1.23 \mathrm{E}-03$ & 7.77E-04 & $2.39 \mathrm{E}-02$ & $1.51 \mathrm{E}-02$ & $5.52 \mathrm{E}-05$ & $3.50 \mathrm{E}-05$ & $1.80 \mathrm{E}-03$ & $1.14 \mathrm{E}-03$ \\
\hline Te-132 & 5.83E-05 & $1.63 \mathrm{E}-04$ & 7.91E-04 & $2.21 \mathrm{E}-03$ & $2.43 \mathrm{E}-06$ & $6.81 \mathrm{E}-06$ & $5.68 \mathrm{E}-05$ & $1.60 \mathrm{E}-04$ \\
\hline Cs-137 & $1.30 \mathrm{E}-02$ & $2.59 \mathrm{E}-03$ & $1.16 \mathrm{E}-02$ & $2.32 \mathrm{E}-03$ & $6.58 \mathrm{E}-03$ & $1.31 \mathrm{E}-03$ & $6.14 \mathrm{E}-03$ & $1.23 \mathrm{E}-03$ \\
\hline Cs-134 & $2.33 \mathrm{E}-03$ & $3.29 \mathrm{E}-03$ & $2.30 \mathrm{E}-03$ & $3.25 \mathrm{E}-03$ & $1.42 \mathrm{E}-03$ & $2.00 \mathrm{E}-03$ & $1.26 \mathrm{E}-03$ & $1.78 \mathrm{E}-03$ \\
\hline $\mathrm{Sr}-90$ & $3.20 \mathrm{E}-04$ & $6.69 \mathrm{E}-03$ & $1.66 \mathrm{E}-05$ & $3.48 \mathrm{E}-04$ & $4.31 \mathrm{E}-05$ & $9.01 \mathrm{E}-04$ & $1.69 \mathrm{E}-06$ & $3.53 \mathrm{E}-05$ \\
\hline Ag-110m & $9.02 \mathrm{E}-03$ & $1.61 \mathrm{E}-02$ & $2.43 \mathrm{E}-03$ & 4.31E-03 & $8.68 \mathrm{E}-04$ & $1.54 \mathrm{E}-03$ & 5.37E-05 & $9.57 \mathrm{E}-05$ \\
\hline Ag-111 & $3.26 \mathrm{E}-02$ & $2.05 \mathrm{E}-01$ & $8.80 \mathrm{E}-04$ & $5.54 \mathrm{E}-03$ & $2.48 \mathrm{E}-03$ & $1.56 \mathrm{E}-02$ & $1.35 \mathrm{E}-05$ & $8.51 \mathrm{E}-05$ \\
\hline $\mathrm{Sb}-125$ & $8.26 \mathrm{E}-07$ & $2.08 \mathrm{E}-07$ & $8.64 \mathrm{E}-07$ & $2.17 \mathrm{E}-07$ & $4.84 \mathrm{E}-08$ & $1.22 \mathrm{E}-08$ & $2.43 \mathrm{E}-09$ & $6.12 \mathrm{E}-10$ \\
\hline Ru-103 & 1.09E-09 & $7.88 \mathrm{E}-08$ & $1.69 \mathrm{E}-10$ & $1.22 \mathrm{E}-08$ & $9.99 \mathrm{E}-11$ & $7.24 \mathrm{E}-09$ & $7.56 \mathrm{E}-12$ & $5.48 \mathrm{E}-10$ \\
\hline Ce-144 & $6.53 \mathrm{E}-06$ & $2.53 \mathrm{E}-06$ & $8.26 \mathrm{E}-08$ & $3.22 \mathrm{E}-08$ & $4.43 \mathrm{E}-07$ & $1.72 \mathrm{E}-07$ & $4.00 \mathrm{E}-10$ & $1.55 \mathrm{E}-10$ \\
\hline La-140 & $1.30 \mathrm{E}-08$ & $3.19 \mathrm{E}-08$ & $8.30 \mathrm{E}-11$ & $2.05 \mathrm{E}-10$ & $1.20 \mathrm{E}-09$ & $2.96 \mathrm{E}-09$ & $3.37 \mathrm{E}-12$ & $8.33 \mathrm{E}-12$ \\
\hline $\mathrm{Pu}-239$ & $4.36 \mathrm{E}-11$ & $1.72 \mathrm{E}-11$ & $5.72 \mathrm{E}-12$ & $2.26 \mathrm{E}-12$ & $1.16 \mathrm{E}-13$ & $4.57 \mathrm{E}-14$ & $6.19 \mathrm{E}-19$ & $2.45 \mathrm{E}-19$ \\
\hline Sum & $7.48 \mathrm{E}-02$ & 2.99E-01 & $3.65 \mathrm{E}-01$ & $1.32 \mathrm{E}+00$ & $1.25 \mathrm{E}-02$ & $2.54 \mathrm{E}-02$ & $4.26 \mathrm{E}-02$ & $1.37 \mathrm{E}-01$ \\
\hline TOTAL & \multicolumn{2}{|c|}{$3.74 \mathrm{E}-01$} & \multicolumn{2}{|c|}{$1.68 \mathrm{E}+00$} & \multicolumn{2}{|c|}{$3.79 \mathrm{E}-02$} & \multicolumn{2}{|c|}{$1.80 \mathrm{E}-01$} \\
\hline Limits (rem) & \multicolumn{2}{|c|}{0.5} & \multicolumn{2}{|c|}{1.5} & \multicolumn{2}{|c|}{0.5} & \multicolumn{2}{|c|}{1.5} \\
\hline
\end{tabular}


Table C-12. $600 \mathrm{MW}(\mathrm{t})$ prismatic $700^{\circ} \mathrm{C}$ ROT - water ingress-Cases E and F, infant and adult- $1600 \mathrm{~m}$ from release (rem).

\begin{tabular}{|c|c|c|c|c|c|c|c|c|}
\hline \multirow[t]{2}{*}{ Nuclide } & \multicolumn{2}{|c|}{$\begin{array}{l}\text { CASE E/Ingestion - milk/ EDE } \\
\text { (infant) }\end{array}$} & \multicolumn{2}{|c|}{$\begin{array}{l}\text { CASE F/Ingestion - milk/ } \\
\text { Thyroid (infant) }\end{array}$} & \multicolumn{2}{|c|}{$\begin{array}{l}\text { CASE E/Ingestion - milk/ EDE } \\
\text { (adult) }\end{array}$} & \multicolumn{2}{|c|}{$\begin{array}{l}\text { CASE F/Ingestion - milk/ } \\
\text { Thyroid (adult) }\end{array}$} \\
\hline & Short & Long & Short & Long & Short & Long & Short & Long \\
\hline Xe-133 & - & - & - & - & - & - & - & - \\
\hline $\mathrm{Kr}-85$ & - & - & - & - & - & - & - & - \\
\hline Kr- 88 & - & - & - & - & - & - & - & - \\
\hline I-131 & $5.92 \mathrm{E}-03$ & $2.44 \mathrm{E}-02$ & $1.18 \mathrm{E}-01$ & $4.85 \mathrm{E}-01$ & $3.67 \mathrm{E}-04$ & $1.52 \mathrm{E}-03$ & $1.22 \mathrm{E}-02$ & $5.01 \mathrm{E}-02$ \\
\hline I-133 & $4.44 \mathrm{E}-04$ & $2.90 \mathrm{E}-04$ & $8.64 \mathrm{E}-03$ & $5.69 \mathrm{E}-03$ & $2.00 \mathrm{E}-05$ & $1.32 \mathrm{E}-05$ & $6.49 \mathrm{E}-04$ & $4.27 \mathrm{E}-04$ \\
\hline Te-132 & $2.12 \mathrm{E}-05$ & $6.18 \mathrm{E}-05$ & 2.89E-04 & 8.33E-04 & $8.85 \mathrm{E}-07$ & $2.57 \mathrm{E}-06$ & 2.07E-05 & $6.02 \mathrm{E}-05$ \\
\hline Cs-137 & $4.71 \mathrm{E}-03$ & $9.81 \mathrm{E}-04$ & $4.23 \mathrm{E}-03$ & $8.75 \mathrm{E}-04$ & $2.40 \mathrm{E}-03$ & 4.97E-04 & $2.24 \mathrm{E}-03$ & $4.64 \mathrm{E}-04$ \\
\hline Cs-134 & $8.46 \mathrm{E}-04$ & $1.24 \mathrm{E}-03$ & $8.39 \mathrm{E}-04$ & $1.23 \mathrm{E}-03$ & $5.17 \mathrm{E}-04$ & $7.56 \mathrm{E}-04$ & $4.60 \mathrm{E}-04$ & $6.73 \mathrm{E}-04$ \\
\hline Sr-90 & $1.17 \mathrm{E}-04$ & $2.52 \mathrm{E}-03$ & $6.07 \mathrm{E}-06$ & $1.31 \mathrm{E}-04$ & $1.57 \mathrm{E}-05$ & $3.40 \mathrm{E}-04$ & $6.18 \mathrm{E}-07$ & $1.33 \mathrm{E}-05$ \\
\hline Ag-110m & $3.28 \mathrm{E}-03$ & $6.04 \mathrm{E}-03$ & $8.85 \mathrm{E}-04$ & $1.63 \mathrm{E}-03$ & $3.17 \mathrm{E}-04$ & $5.82 \mathrm{E}-04$ & $1.96 \mathrm{E}-05$ & $3.61 \mathrm{E}-05$ \\
\hline Ag-111 & $1.19 \mathrm{E}-02$ & $7.75 \mathrm{E}-02$ & $3.21 \mathrm{E}-04$ & $2.10 \mathrm{E}-03$ & $9.04 \mathrm{E}-04$ & 5.89E-03 & $4.93 \mathrm{E}-06$ & $3.21 \mathrm{E}-05$ \\
\hline $\mathrm{Sb}-125$ & $3.00 \mathrm{E}-07$ & 7.83E-08 & $3.15 \mathrm{E}-07$ & $8.11 \mathrm{E}-08$ & $1.76 \mathrm{E}-08$ & 4.57E-09 & $8.87 \mathrm{E}-10$ & $2.30 \mathrm{E}-10$ \\
\hline Ru-103 & $3.97 \mathrm{E}-10$ & $2.98 \mathrm{E}-08$ & $6.18 \mathrm{E}-11$ & 4.64E-09 & $3.65 \mathrm{E}-11$ & $2.74 \mathrm{E}-09$ & $2.77 \mathrm{E}-12$ & $2.06 \mathrm{E}-10$ \\
\hline $\mathrm{Ce}-144$ & $2.38 \mathrm{E}-06$ & $9.56 \mathrm{E}-07$ & $3.02 \mathrm{E}-08$ & $1.22 \mathrm{E}-08$ & $1.61 \mathrm{E}-07$ & $6.49 \mathrm{E}-08$ & $1.46 \mathrm{E}-10$ & $5.86 \mathrm{E}-11$ \\
\hline La-140 & 4.72E-09 & $1.20 \mathrm{E}-08$ & $3.02 \mathrm{E}-11$ & $7.73 \mathrm{E}-11$ & $4.37 \mathrm{E}-10$ & $1.11 \mathrm{E}-09$ & $1.23 \mathrm{E}-12$ & $3.13 \mathrm{E}-12$ \\
\hline Pu-239 & $1.59 \mathrm{E}-11$ & $6.47 \mathrm{E}-12$ & $2.09 \mathrm{E}-12$ & $8.49 \mathrm{E}-13$ & $4.21 \mathrm{E}-14$ & $1.72 \mathrm{E}-14$ & $2.25 \mathrm{E}-19$ & $9.20 \mathrm{E}-20$ \\
\hline Sum & 2.72E-02 & 1.13E-01 & $1.33 \mathrm{E}-01$ & $4.98 \mathrm{E}-01$ & $4.54 \mathrm{E}-03$ & $9.60 \mathrm{E}-03$ & $1.56 \mathrm{E}-02$ & 5.18E-02 \\
\hline TOTAL & \multicolumn{2}{|c|}{$1.40 \mathrm{E}-01$} & \multicolumn{2}{|c|}{ 6.31E-01 } & \multicolumn{2}{|c|}{$1.41 \mathrm{E}-02$} & \multicolumn{2}{|c|}{ 6.74E-02 } \\
\hline Limits (rem) & \multicolumn{2}{|c|}{0.5} & \multicolumn{2}{|c|}{1.5} & \multicolumn{2}{|c|}{0.5} & \multicolumn{2}{|c|}{1.5} \\
\hline
\end{tabular}


C-2. $600 \mathrm{MW}(\mathrm{t})$ Prismatic $900^{\circ} \mathrm{C}$

\section{C-2.1 Accident Scenario: Break in Helium Pressure Boundary}

\section{C-2.1.1 Source Term}

Table C-13. $600 \mathrm{MW}(\mathrm{t})$ prismatic $900^{\circ} \mathrm{C}$ ROT- break in HPB-source term (curies).

\begin{tabular}{|c|c|c|c|c|c|c|c|c|}
\hline \multirow{2}{*}{ Nuclide } & \multicolumn{4}{|c|}{ Release to Environment Short Term } & \multicolumn{4}{|c|}{ Release to Environment Long Term } \\
\hline & DBA & $50 \%$ & Mean & $95 \%$ & DBA & $50 \%$ & Mean & $95 \%$ \\
\hline Xe-133 & $1.04 \mathrm{E}+02$ & $1.04 \mathrm{E}+02$ & $1.04 \mathrm{E}+02$ & $1.04 \mathrm{E}+02$ & $1.94 \mathrm{E}+02$ & $5.64 \mathrm{E}+01$ & $7.42 \mathrm{E}+01$ & $1.94 \mathrm{E}+02$ \\
\hline $\mathrm{Kr}-85$ & $5.34 \mathrm{E}-01$ & 5.34E-01 & $5.34 \mathrm{E}-01$ & $5.34 \mathrm{E}-01$ & $1.40 \mathrm{E}+00$ & $3.90 \mathrm{E}-01$ & $5.19 \mathrm{E}-01$ & $1.40 \mathrm{E}+00$ \\
\hline $\mathrm{Kr}-88$ & $5.32 \mathrm{E}+01$ & $5.32 \mathrm{E}+01$ & $5.32 \mathrm{E}+01$ & $5.32 \mathrm{E}+01$ & $5.51 \mathrm{E}-04$ & $1.58 \mathrm{E}-04$ & $2.10 \mathrm{E}-04$ & $5.51 \mathrm{E}-04$ \\
\hline $\mathrm{I}-131$ & $2.86 \mathrm{E}+00$ & $1.40 \mathrm{E}-01$ & 4.03E-01 & $1.57 \mathrm{E}+00$ & $1.17 \mathrm{E}+02$ & $3.35 \mathrm{E}+00$ & $6.95 \mathrm{E}+00$ & $2.46 \mathrm{E}+01$ \\
\hline $\mathrm{I}-133$ & $4.96 \mathrm{E}+00$ & $2.53 \mathrm{E}-01$ & $7.12 \mathrm{E}-01$ & $2.61 \mathrm{E}+00$ & $4.86 \mathrm{E}+01$ & $1.33 \mathrm{E}+00$ & $2.90 \mathrm{E}+00$ & $1.08 \mathrm{E}+01$ \\
\hline Te-132 & $3.77 \mathrm{E}+00$ & $1.83 \mathrm{E}-01$ & $5.31 \mathrm{E}-01$ & $2.05 \mathrm{E}+00$ & $1.22 \mathrm{E}+02$ & $3.37 \mathrm{E}+00$ & $7.19 \mathrm{E}+00$ & $2.66 \mathrm{E}+01$ \\
\hline Cs-137 & $8.45 \mathrm{E}+01$ & $4.23 \mathrm{E}+00$ & $1.18 \mathrm{E}+01$ & $4.57 \mathrm{E}+01$ & $4.61 \mathrm{E}+01$ & $4.96 \mathrm{E}-01$ & $1.93 \mathrm{E}+00$ & $7.93 \mathrm{E}+00$ \\
\hline Cs-134 & $1.43 \mathrm{E}+01$ & $7.17 \mathrm{E}-01$ & $2.03 \mathrm{E}+00$ & $8.04 \mathrm{E}+00$ & $5.71 \mathrm{E}+01$ & $5.86 \mathrm{E}-01$ & $2.34 \mathrm{E}+00$ & $9.34 \mathrm{E}+00$ \\
\hline Sr-90 & $7.60 \mathrm{E}+00$ & 3.83E-01 & $1.10 \mathrm{E}+00$ & $4.09 \mathrm{E}+00$ & $2.43 \mathrm{E}+01$ & $4.16 \mathrm{E}-01$ & $1.13 \mathrm{E}+00$ & $4.33 \mathrm{E}+00$ \\
\hline Ag-110m & $8.07 \mathrm{E}+00$ & $4.03 \mathrm{E}-01$ & $1.22 \mathrm{E}+00$ & $4.61 \mathrm{E}+00$ & $4.44 \mathrm{E}+01$ & $6.89 \mathrm{E}-01$ & $2.03 \mathrm{E}+00$ & $7.75 \mathrm{E}+00$ \\
\hline Ag-111 & $2.13 \mathrm{E}+02$ & $1.04 \mathrm{E}+01$ & $2.95 \mathrm{E}+01$ & $1.14 \mathrm{E}+02$ & $3.81 \mathrm{E}+03$ & $6.04 \mathrm{E}+01$ & $1.75 \mathrm{E}+02$ & $6.33 \mathrm{E}+02$ \\
\hline Sb-125 & 7.01E-01 & $3.47 \mathrm{E}-02$ & $1.03 \mathrm{E}-01$ & $3.94 \mathrm{E}-01$ & $7.43 \mathrm{E}-01$ & 8.98E-03 & $3.13 \mathrm{E}-02$ & $1.25 \mathrm{E}-01$ \\
\hline Ru-103 & $1.02 \mathrm{E}-01$ & $5.04 \mathrm{E}-03$ & $1.42 \mathrm{E}-02$ & $5.50 \mathrm{E}-02$ & $5.13 \mathrm{E}+01$ & 8.77E-01 & $2.40 \mathrm{E}+00$ & $8.78 \mathrm{E}+00$ \\
\hline $\mathrm{Ce}-144$ & $1.20 \mathrm{E}+00$ & $6.03 \mathrm{E}-02$ & $1.74 \mathrm{E}-01$ & $6.56 \mathrm{E}-01$ & $3.54 \mathrm{E}+00$ & $5.99 \mathrm{E}-02$ & $1.68 \mathrm{E}-01$ & $6.39 \mathrm{E}-01$ \\
\hline La-140 & $9.38 \mathrm{E}-02$ & 4.63E-03 & $1.34 \mathrm{E}-02$ & $5.03 \mathrm{E}-02$ & $2.08 \mathrm{E}+00$ & $3.53 \mathrm{E}-02$ & $9.80 \mathrm{E}-02$ & $3.81 \mathrm{E}-01$ \\
\hline $\mathrm{Pu}-239$ & 8.94E-06 & $4.46 \mathrm{E}-07$ & $1.30 \mathrm{E}-06$ & $4.90 \mathrm{E}-06$ & $5.72 \mathrm{E}-05$ & $1.01 \mathrm{E}-06$ & $2.77 \mathrm{E}-06$ & $1.06 \mathrm{E}-05$ \\
\hline
\end{tabular}


Table C-14. $600 \mathrm{MW}(\mathrm{t})$ prismatic $900^{\circ} \mathrm{C}$ ROT_-break in HPB - Cases A and B- $400 \mathrm{~m}$ from release (rem).

\begin{tabular}{|c|c|c|c|c|}
\hline \multirow[t]{2}{*}{ Nuclide } & \multicolumn{2}{|c|}{$\begin{array}{l}\text { Case A/EAB } \\
(400 \mathrm{~m}) / \mathrm{TEDE}\end{array}$} & \multicolumn{2}{|c|}{$\begin{array}{c}\text { Case B/LPZ } \\
(400 \mathrm{~m}) / \mathrm{TEDE}\end{array}$} \\
\hline & Short & Long & Short & Long \\
\hline Xe-133 & $4.87 \mathrm{E}-05$ & & $4.87 \mathrm{E}-05$ & $6.15 \mathrm{E}-05$ \\
\hline $\mathrm{Kr}-85$ & $2.09 \mathrm{E}-08$ & & $2.09 \mathrm{E}-08$ & $3.66 \mathrm{E}-08$ \\
\hline $\mathrm{Kr}-88$ & $1.62 \mathrm{E}-03$ & & $1.62 \mathrm{E}-03$ & $5.56 \mathrm{E}-09$ \\
\hline I-131 & $5.71 \mathrm{E}-03$ & & $5.71 \mathrm{E}-03$ & $1.33 \mathrm{E}-01$ \\
\hline $\mathrm{I}-133$ & $1.52 \mathrm{E}-03$ & & $1.52 \mathrm{E}-03$ & 7.49E-03 \\
\hline Te-132 & $2.81 \mathrm{E}-03$ & & $2.81 \mathrm{E}-03$ & $6.29 \mathrm{E}-02$ \\
\hline Cs-137 & $1.71 \mathrm{E}-01$ & & $1.71 \mathrm{E}-01$ & 5.54E-02 \\
\hline Cs-134 & 4.31E-02 & & $4.31 \mathrm{E}-02$ & $1.11 \mathrm{E}-01$ \\
\hline Sr-90 & $7.75 \mathrm{E}-02$ & & $7.75 \mathrm{E}-02$ & $2.18 \mathrm{E}-01$ \\
\hline $\mathrm{Ag}-110 \mathrm{~m}$ & 4.07E-02 & & 4.07E-02 & $1.42 \mathrm{E}-01$ \\
\hline Ag-111 & $6.46 \mathrm{E}-02$ & & $6.46 \mathrm{E}-02$ & $8.31 \mathrm{E}-01$ \\
\hline Sb-125 & $1.46 \mathrm{E}-04$ & & $1.46 \mathrm{E}-04$ & $9.14 \mathrm{E}-05$ \\
\hline $\mathrm{Ru}-103$ & $5.27 \mathrm{E}-05$ & & $5.27 \mathrm{E}-05$ & $1.87 \mathrm{E}-02$ \\
\hline Ce-144 & $2.40 \mathrm{E}-02$ & & $2.40 \mathrm{E}-02$ & 4.57E-02 \\
\hline La-140 & $4.84 \mathrm{E}-05$ & & 4.84E-05 & $5.66 \mathrm{E}-04$ \\
\hline $\mathrm{Pu}-239$ & $1.03 \mathrm{E}-04$ & & $1.03 \mathrm{E}-04$ & $6.29 \mathrm{E}-04$ \\
\hline Sum & 4.33E-01 & $0.00 E+00$ & 4.33E-01 & $1.63 E+00$ \\
\hline TOTAL & \multicolumn{2}{|c|}{ 4.33E-01 } & \multicolumn{2}{|c|}{$2.06 \mathrm{E}+00$} \\
\hline Limits (rem) & \multicolumn{4}{|c|}{25} \\
\hline
\end{tabular}


Table C-15. $600 \mathrm{MW}(\mathrm{t})$ prismatic $900^{\circ} \mathrm{C}$ ROT_-break in HPB — Cases C and D-400 m from release (rem).

\begin{tabular}{|c|c|c|c|c|}
\hline \multirow[t]{2}{*}{ Nuclide } & \multicolumn{2}{|c|}{$\begin{array}{l}\text { CASE C/Inh, grndshine, } \\
\text { cldshine/TEDE }\end{array}$} & \multicolumn{2}{|c|}{$\begin{array}{l}\text { CASE D/Inh, grndshine, } \\
\text { cldshine/Thyroid }\end{array}$} \\
\hline & Short & Long & Short & Long \\
\hline Xe-133 & $1.95 \mathrm{E}-05$ & $1.41 \mathrm{E}-05$ & & \\
\hline $\mathrm{Kr}-85$ & 7.64E-09 & $8.15 \mathrm{E}-09$ & & \\
\hline $\mathrm{Kr}-88$ & $7.23 \mathrm{E}-04$ & $9.31 \mathrm{E}-10$ & & \\
\hline I-131 & $2.49 \mathrm{E}-04$ & $4.81 \mathrm{E}-03$ & $7.89 \mathrm{E}-03$ & $1.54 \mathrm{E}-01$ \\
\hline I-133 & $8.48 \mathrm{E}-05$ & $2.68 \mathrm{E}-04$ & $2.30 \mathrm{E}-03$ & $7.25 \mathrm{E}-03$ \\
\hline Te-132 & $1.42 \mathrm{E}-04$ & $2.03 \mathrm{E}-03$ & $2.29 \mathrm{E}-03$ & $3.29 \mathrm{E}-02$ \\
\hline Cs-137 & 7.72E-03 & $1.47 \mathrm{E}-03$ & & \\
\hline Cs-134 & $1.91 \mathrm{E}-03$ & $2.55 \mathrm{E}-03$ & & \\
\hline Sr-90 & $4.79 \mathrm{E}-03$ & $5.89 \mathrm{E}-03$ & & \\
\hline $\mathrm{Ag}-110 \mathrm{~m}$ & $2.01 \mathrm{E}-03$ & $3.85 \mathrm{E}-03$ & & \\
\hline Ag-111 & $3.33 \mathrm{E}-03$ & $2.20 \mathrm{E}-02$ & & \\
\hline $\mathrm{Sb}-125$ & $6.86 \mathrm{E}-06$ & $2.28 \mathrm{E}-06$ & & \\
\hline Ru-103 & $2.75 \mathrm{E}-06$ & $5.26 \mathrm{E}-04$ & & \\
\hline $\mathrm{Ce}-144$ & $1.19 \mathrm{E}-03$ & $1.36 \mathrm{E}-03$ & & \\
\hline La-140 & $2.20 \mathrm{E}-06$ & $1.46 \mathrm{E}-05$ & & \\
\hline $\mathrm{Pu}-239$ & $7.30 \mathrm{E}-06$ & $1.84 \mathrm{E}-05$ & & \\
\hline Sum & 2.22E-02 & $4.48 \mathrm{E}-02$ & $1.25 \mathrm{E}-02$ & $1.94 \mathrm{E}-01$ \\
\hline TOTAL & \multicolumn{2}{|c|}{$6.70 \mathrm{E}-02$} & \multicolumn{2}{|c|}{$2.06 \mathrm{E}-01$} \\
\hline Limits (rem) & \multicolumn{2}{|c|}{1} & \multicolumn{2}{|c|}{5} \\
\hline
\end{tabular}


Table C-16. $600 \mathrm{MW}(\mathrm{t})$ prismatic $900^{\circ} \mathrm{C}$ ROT — break in HPB — Cases E and F, infant and adult - $400 \mathrm{~m}$ from release (rem).

\begin{tabular}{|c|c|c|c|c|c|c|c|c|}
\hline \multirow[t]{2}{*}{ Nuclide } & \multicolumn{2}{|c|}{$\begin{array}{c}\text { CASE E/Ingestion - milk/ } \\
\text { EDE (infant) }\end{array}$} & \multicolumn{2}{|c|}{$\begin{array}{l}\text { CASE F/Ingestion - milk/ } \\
\text { Thyroid (infant) }\end{array}$} & \multicolumn{2}{|c|}{$\begin{array}{l}\text { CASE E/Ingestion - milk/ } \\
\text { EDE (adult) }\end{array}$} & \multicolumn{2}{|c|}{$\begin{array}{l}\text { CASE F/Ingestion - milk/ } \\
\text { Thyroid (adult) }\end{array}$} \\
\hline & Short & Long & Short & Long & Short & Long & Short & Long \\
\hline Xe-133 & - & - & - & - & - & - & - & - \\
\hline $\mathrm{Kr}-85$ & - & - & - & - & - & - & - & - \\
\hline Kr- 88 & - & - & - & - & - & - & - & - \\
\hline $\mathrm{I}-131$ & $9.34 \mathrm{E}-03$ & $1.75 \mathrm{E}-01$ & $1.86 \mathrm{E}-01$ & $3.47 \mathrm{E}+00$ & $5.80 \mathrm{E}-04$ & $1.08 \mathrm{E}-02$ & $1.92 \mathrm{E}-02$ & $3.58 \mathrm{E}-01$ \\
\hline I-133 & $7.10 \mathrm{E}-04$ & $2.13 \mathrm{E}-03$ & $1.38 \mathrm{E}-02$ & $4.15 \mathrm{E}-02$ & $3.20 \mathrm{E}-05$ & $9.62 \mathrm{E}-05$ & $1.04 \mathrm{E}-03$ & $3.13 \mathrm{E}-03$ \\
\hline Te-132 & $3.32 \mathrm{E}-05$ & $4.51 \mathrm{E}-04$ & $4.51 \mathrm{E}-04$ & $6.10 \mathrm{E}-03$ & $1.39 \mathrm{E}-06$ & $1.88 \mathrm{E}-05$ & $3.25 \mathrm{E}-05$ & $4.39 \mathrm{E}-04$ \\
\hline Cs-137 & $1.02 \mathrm{E}-01$ & $1.91 \mathrm{E}-02$ & $9.17 \mathrm{E}-02$ & $1.71 \mathrm{E}-02$ & $5.20 \mathrm{E}-02$ & $9.68 \mathrm{E}-03$ & $4.85 \mathrm{E}-02$ & $9.04 \mathrm{E}-03$ \\
\hline Cs-134 & $2.02 \mathrm{E}-02$ & $2.64 \mathrm{E}-02$ & $2.00 \mathrm{E}-02$ & $2.62 \mathrm{E}-02$ & $1.23 \mathrm{E}-02$ & $1.61 \mathrm{E}-02$ & $1.10 \mathrm{E}-02$ & $1.43 \mathrm{E}-02$ \\
\hline Sr-90 & $1.81 \mathrm{E}-02$ & $2.13 \mathrm{E}-02$ & $9.44 \mathrm{E}-04$ & $1.11 \mathrm{E}-03$ & $2.45 \mathrm{E}-03$ & $2.87 \mathrm{E}-03$ & $9.59 \mathrm{E}-05$ & $1.13 \mathrm{E}-04$ \\
\hline $\mathrm{Ag}-110 \mathrm{~m}$ & $2.32 \mathrm{E}-02$ & $4.36 \mathrm{E}-02$ & $6.25 \mathrm{E}-03$ & $1.18 \mathrm{E}-02$ & $2.23 \mathrm{E}-03$ & $4.19 \mathrm{E}-03$ & $1.38 \mathrm{E}-04$ & $2.59 \mathrm{E}-04$ \\
\hline Ag-111 & $9.85 \mathrm{E}-02$ & $6.28 \mathrm{E}-01$ & $2.67 \mathrm{E}-03$ & $1.70 \mathrm{E}-02$ & 7.49E-03 & $4.78 \mathrm{E}-02$ & $4.10 \mathrm{E}-05$ & $2.61 \mathrm{E}-04$ \\
\hline Sb-125 & $9.25 \mathrm{E}-06$ & $3.19 \mathrm{E}-06$ & $9.69 \mathrm{E}-06$ & $3.35 \mathrm{E}-06$ & $5.42 \mathrm{E}-07$ & $1.87 \mathrm{E}-07$ & $2.72 \mathrm{E}-08$ & $9.39 \mathrm{E}-09$ \\
\hline Ru-103 & $1.58 \mathrm{E}-09$ & $3.00 \mathrm{E}-07$ & $2.46 \mathrm{E}-10$ & 4.66E-08 & $1.45 \mathrm{E}-10$ & $2.76 \mathrm{E}-08$ & $1.10 \mathrm{E}-11$ & $2.09 \mathrm{E}-09$ \\
\hline Ce-144 & $9.31 \mathrm{E}-06$ & $1.02 \mathrm{E}-05$ & $1.18 \mathrm{E}-07$ & $1.30 \mathrm{E}-07$ & $6.31 \mathrm{E}-07$ & $6.92 \mathrm{E}-07$ & $5.70 \mathrm{E}-10$ & $6.24 \mathrm{E}-10$ \\
\hline La-140 & $1.93 \mathrm{E}-08$ & $1.26 \mathrm{E}-07$ & $1.24 \mathrm{E}-10$ & $8.08 \mathrm{E}-10$ & $1.78 \mathrm{E}-09$ & $1.17 \mathrm{E}-08$ & $5.03 \mathrm{E}-12$ & $3.28 \mathrm{E}-11$ \\
\hline $\mathrm{Pu}-239$ & $2.49 \mathrm{E}-11$ & $6.01 \mathrm{E}-11$ & $3.27 \mathrm{E}-12$ & $7.89 \mathrm{E}-12$ & $6.60 \mathrm{E}-14$ & $1.60 \mathrm{E}-13$ & $3.54 \mathrm{E}-19$ & $8.56 \mathrm{E}-19$ \\
\hline Sum & 2.73E-01 & $9.16 \mathrm{E}-01$ & $3.22 \mathrm{E}-01$ & $3.59 \mathrm{E}+00$ & $7.71 \mathrm{E}-02$ & $9.16 \mathrm{E}-02$ & $8.00 \mathrm{E}-02$ & $3.86 \mathrm{E}-01$ \\
\hline TOTAL & \multicolumn{2}{|c|}{$1.19 \mathrm{E}+00$} & \multicolumn{2}{|c|}{$3.91 \mathrm{E}+00$} & \multicolumn{2}{|c|}{$1.69 \mathrm{E}-01$} & \multicolumn{2}{|c|}{$4.66 \mathrm{E}-01$} \\
\hline Limits (rem) & \multicolumn{2}{|c|}{0.5} & \multicolumn{2}{|c|}{1.5} & \multicolumn{2}{|c|}{0.5} & \multicolumn{2}{|c|}{1.5} \\
\hline
\end{tabular}


Table C-17. $600 \mathrm{MW}(\mathrm{t})$ prismatic $900^{\circ} \mathrm{C}$ ROT — break in HPB — Cases E and F, infant and adult- $800 \mathrm{~m}$ from release (rem).

\begin{tabular}{|c|c|c|c|c|c|c|c|c|}
\hline \multirow{2}{*}{ Nuclide } & \multicolumn{2}{|c|}{$\begin{array}{c}\text { CASE E/Ingestion - milk/ } \\
\text { EDE (infant) }\end{array}$} & \multicolumn{2}{|c|}{$\begin{array}{l}\text { CASE F/Ingestion - milk/ } \\
\text { Thyroid (infant) }\end{array}$} & \multicolumn{2}{|c|}{$\begin{array}{l}\text { CASE E/Ingestion - milk/ } \\
\text { EDE (adult) }\end{array}$} & \multicolumn{2}{|c|}{$\begin{array}{c}\text { CASE F/Ingestion - milk/ } \\
\text { Thyroid (adult) }\end{array}$} \\
\hline & Short & Long & Short & Long & Short & Long & Short & Long \\
\hline Xe-133 & - & - & - & - & - & - & - & - \\
\hline $\mathrm{Kr}-85$ & - & - & - & - & - & - & - & - \\
\hline Kr- 88 & - & - & - & - & - & - & - & - \\
\hline $\mathrm{I}-131$ & $3.44 \mathrm{E}-03$ & $6.50 \mathrm{E}-02$ & $6.84 \mathrm{E}-02$ & $1.29 \mathrm{E}+00$ & $2.13 \mathrm{E}-04$ & $4.04 \mathrm{E}-03$ & $7.05 \mathrm{E}-03$ & $1.34 \mathrm{E}-01$ \\
\hline I-133 & $2.60 \mathrm{E}-04$ & $7.91 \mathrm{E}-04$ & $5.06 \mathrm{E}-03$ & $1.54 \mathrm{E}-02$ & $1.17 \mathrm{E}-05$ & $3.57 \mathrm{E}-05$ & $3.80 \mathrm{E}-04$ & $1.16 \mathrm{E}-03$ \\
\hline Te-132 & $1.22 \mathrm{E}-05$ & $1.68 \mathrm{E}-04$ & $1.66 \mathrm{E}-04$ & $2.27 \mathrm{E}-03$ & 5.09E-07 & $6.99 \mathrm{E}-06$ & $1.19 \mathrm{E}-05$ & $1.64 \mathrm{E}-04$ \\
\hline Cs-137 & $3.76 \mathrm{E}-02$ & $7.09 \mathrm{E}-03$ & $3.36 \mathrm{E}-02$ & $6.36 \mathrm{E}-03$ & $1.91 \mathrm{E}-02$ & $3.59 \mathrm{E}-03$ & $1.78 \mathrm{E}-02$ & $3.36 \mathrm{E}-03$ \\
\hline Cs-134 & $7.44 \mathrm{E}-03$ & $9.84 \mathrm{E}-03$ & $7.33 \mathrm{E}-03$ & $9.72 \mathrm{E}-03$ & $4.53 \mathrm{E}-03$ & $5.98 \mathrm{E}-03$ & $4.02 \mathrm{E}-03$ & $5.33 \mathrm{E}-03$ \\
\hline Sr-90 & $6.65 \mathrm{E}-03$ & $7.91 \mathrm{E}-03$ & $3.46 \mathrm{E}-04$ & 4.11E-04 & $8.96 \mathrm{E}-04$ & $1.06 \mathrm{E}-03$ & $3.51 \mathrm{E}-05$ & 4.17E-05 \\
\hline Ag-110m & $8.50 \mathrm{E}-03$ & $1.62 \mathrm{E}-02$ & $2.29 \mathrm{E}-03$ & $4.36 \mathrm{E}-03$ & $8.19 \mathrm{E}-04$ & $1.56 \mathrm{E}-03$ & $5.07 \mathrm{E}-05$ & $9.67 \mathrm{E}-05$ \\
\hline Ag-111 & $3.63 \mathrm{E}-02$ & $2.34 \mathrm{E}-01$ & $9.79 \mathrm{E}-04$ & $6.33 \mathrm{E}-03$ & $2.75 \mathrm{E}-03$ & $1.78 \mathrm{E}-02$ & $1.50 \mathrm{E}-05$ & $9.73 \mathrm{E}-05$ \\
\hline Sb-125 & $3.38 \mathrm{E}-06$ & $1.18 \mathrm{E}-06$ & $3.54 \mathrm{E}-06$ & $1.23 \mathrm{E}-06$ & $1.98 \mathrm{E}-07$ & $6.92 \mathrm{E}-08$ & $9.96 \mathrm{E}-09$ & $3.47 \mathrm{E}-09$ \\
\hline Ru-103 & $5.81 \mathrm{E}-10$ & $1.12 \mathrm{E}-07$ & $9.04 \mathrm{E}-11$ & $1.74 \mathrm{E}-08$ & $5.34 \mathrm{E}-11$ & $1.03 \mathrm{E}-08$ & $4.04 \mathrm{E}-12$ & $7.78 \mathrm{E}-10$ \\
\hline Ce-144 & $3.42 \mathrm{E}-06$ & $3.79 \mathrm{E}-06$ & $4.32 \mathrm{E}-08$ & 4.81E-08 & $2.32 \mathrm{E}-07$ & $2.58 \mathrm{E}-07$ & $2.09 \mathrm{E}-10$ & $2.32 \mathrm{E}-10$ \\
\hline La-140 & 7.08E-09 & 4.69E-08 & $4.53 \mathrm{E}-11$ & $3.01 \mathrm{E}-10$ & $6.57 \mathrm{E}-10$ & 4.36E-09 & $1.84 \mathrm{E}-12$ & $1.22 \mathrm{E}-11$ \\
\hline $\mathrm{Pu}-239$ & $9.11 \mathrm{E}-12$ & $2.23 \mathrm{E}-11$ & $1.20 \mathrm{E}-12$ & $2.94 \mathrm{E}-12$ & $2.42 \mathrm{E}-14$ & $5.93 \mathrm{E}-14$ & $1.30 \mathrm{E}-19$ & $3.18 \mathrm{E}-19$ \\
\hline Sum & $1.00 \mathrm{E}-01$ & $3.41 \mathrm{E}-01$ & $1.18 \mathrm{E}-01$ & $1.34 \mathrm{E}+00$ & $2.83 \mathrm{E}-02$ & $3.41 \mathrm{E}-02$ & $2.94 \mathrm{E}-02$ & $1.44 \mathrm{E}-01$ \\
\hline TOTAL & \multicolumn{2}{|c|}{$4.42 \mathrm{E}-01$} & \multicolumn{2}{|c|}{$1.46 \mathrm{E}+00$} & \multicolumn{2}{|c|}{$6.25 \mathrm{E}-02$} & \multicolumn{2}{|c|}{$1.73 \mathrm{E}-01$} \\
\hline Limits (rem) & \multicolumn{2}{|c|}{0.5} & \multicolumn{2}{|c|}{1.5} & \multicolumn{2}{|c|}{0.5} & \multicolumn{2}{|c|}{1.5} \\
\hline
\end{tabular}


Table C-18. $600 \mathrm{MW}(\mathrm{t})$ prismatic $900^{\circ} \mathrm{C}$ ROT - break in HPB-Cases E and F, infant and adult - $1600 \mathrm{~m}$ from release (rem).

\begin{tabular}{|c|c|c|c|c|c|c|c|c|}
\hline \multirow{2}{*}{ Nuclide } & \multicolumn{2}{|c|}{$\begin{array}{l}\text { CASE E/Ingestion - milk/ } \\
\text { EDE (infant) }\end{array}$} & \multicolumn{2}{|c|}{$\begin{array}{l}\text { CASE F/Ingestion - milk/ } \\
\text { Thyroid (infant) }\end{array}$} & \multicolumn{2}{|c|}{$\begin{array}{l}\text { CASE E/Ingestion - milk/ } \\
\text { EDE (adult) }\end{array}$} & \multicolumn{2}{|c|}{$\begin{array}{l}\text { CASE F/Ingestion - milk/ } \\
\text { Thyroid (adult) }\end{array}$} \\
\hline & Short & Long & Short & Long & Short & Long & Short & Long \\
\hline Xe-133 & - & - & - & - & - & - & - & - \\
\hline $\mathrm{Kr}-85$ & - & - & - & - & - & - & - & - \\
\hline $\mathrm{Kr}-88$ & - & - & - & - & - & - & - & - \\
\hline I-131 & $1.25 \mathrm{E}-03$ & $2.45 \mathrm{E}-02$ & $2.49 \mathrm{E}-02$ & $4.89 \mathrm{E}-01$ & 7.77E-05 & $1.53 \mathrm{E}-03$ & $2.57 \mathrm{E}-03$ & $5.05 \mathrm{E}-02$ \\
\hline I-133 & $9.40 \mathrm{E}-05$ & $2.96 \mathrm{E}-04$ & $1.83 \mathrm{E}-03$ & $5.80 \mathrm{E}-03$ & $4.24 \mathrm{E}-06$ & $1.34 \mathrm{E}-05$ & $1.37 \mathrm{E}-04$ & $4.35 \mathrm{E}-04$ \\
\hline Te-132 & $4.45 \mathrm{E}-06$ & $6.34 \mathrm{E}-05$ & $6.06 \mathrm{E}-05$ & $8.55 \mathrm{E}-04$ & $1.85 \mathrm{E}-07$ & $2.64 \mathrm{E}-06$ & $4.34 \mathrm{E}-06$ & $6.18 \mathrm{E}-05$ \\
\hline Cs-137 & $1.37 \mathrm{E}-02$ & $2.69 \mathrm{E}-03$ & $1.23 \mathrm{E}-02$ & $2.40 \mathrm{E}-03$ & $6.97 \mathrm{E}-03$ & $1.36 \mathrm{E}-03$ & $6.50 \mathrm{E}-03$ & $1.27 \mathrm{E}-03$ \\
\hline Cs-134 & $2.70 \mathrm{E}-03$ & $3.72 \mathrm{E}-03$ & $2.68 \mathrm{E}-03$ & $3.67 \mathrm{E}-03$ & $1.65 \mathrm{E}-03$ & $2.26 \mathrm{E}-03$ & $1.47 \mathrm{E}-03$ & $2.01 \mathrm{E}-03$ \\
\hline Sr-90 & $2.43 \mathrm{E}-03$ & $2.98 \mathrm{E}-03$ & $1.26 \mathrm{E}-04$ & $1.55 \mathrm{E}-04$ & $3.26 \mathrm{E}-04$ & $4.01 \mathrm{E}-04$ & $1.28 \mathrm{E}-05$ & $1.57 \mathrm{E}-05$ \\
\hline $\mathrm{Ag}-110 \mathrm{~m}$ & $3.10 \mathrm{E}-03$ & $6.10 \mathrm{E}-03$ & $8.34 \mathrm{E}-04$ & $1.64 \mathrm{E}-03$ & $2.99 \mathrm{E}-04$ & $5.88 \mathrm{E}-04$ & $1.85 \mathrm{E}-05$ & $3.65 \mathrm{E}-05$ \\
\hline Ag-111 & $1.32 \mathrm{E}-02$ & $8.85 \mathrm{E}-02$ & $3.57 \mathrm{E}-04$ & $2.40 \mathrm{E}-03$ & $1.01 \mathrm{E}-03$ & $6.74 \mathrm{E}-03$ & $5.48 \mathrm{E}-06$ & $3.67 \mathrm{E}-05$ \\
\hline Sb-125 & $1.23 \mathrm{E}-06$ & 4.44E-07 & $1.29 \mathrm{E}-06$ & $4.60 \mathrm{E}-07$ & $7.21 \mathrm{E}-08$ & $2.59 \mathrm{E}-08$ & 3.63E-09 & $1.30 \mathrm{E}-09$ \\
\hline Ru-103 & $2.12 \mathrm{E}-10$ & $4.23 \mathrm{E}-08$ & $3.30 \mathrm{E}-11$ & $6.58 \mathrm{E}-09$ & $1.95 \mathrm{E}-11$ & $3.89 \mathrm{E}-09$ & $1.48 \mathrm{E}-12$ & $2.93 \mathrm{E}-10$ \\
\hline Ce-144 & $1.25 \mathrm{E}-06$ & $1.43 \mathrm{E}-06$ & $1.58 \mathrm{E}-08$ & $1.82 \mathrm{E}-08$ & $8.44 \mathrm{E}-08$ & $9.70 \mathrm{E}-08$ & $7.62 \mathrm{E}-11$ & $8.75 \mathrm{E}-11$ \\
\hline La-140 & 2.57E-09 & $1.76 \mathrm{E}-08$ & $1.65 \mathrm{E}-11$ & $1.14 \mathrm{E}-10$ & $2.39 \mathrm{E}-10$ & $1.64 \mathrm{E}-09$ & $6.70 \mathrm{E}-13$ & $4.61 \mathrm{E}-12$ \\
\hline Pu-239 & $3.32 \mathrm{E}-12$ & $8.39 \mathrm{E}-12$ & $4.36 \mathrm{E}-13$ & $1.10 \mathrm{E}-12$ & $8.80 \mathrm{E}-15$ & $2.23 \mathrm{E}-14$ & $4.71 \mathrm{E}-20$ & $1.19 \mathrm{E}-19$ \\
\hline Sum & $3.65 \mathrm{E}-02$ & $1.29 \mathrm{E}-01$ & 4.31E-02 & $5.06 \mathrm{E}-01$ & $1.03 E-02$ & $1.29 \mathrm{E}-02$ & $1.07 E-02$ & 5.44E-02 \\
\hline TOTAL & \multicolumn{2}{|c|}{$1.65 \mathrm{E}-01$} & \multicolumn{2}{|c|}{ 5.49E-01 } & \multicolumn{2}{|c|}{ 2.32E-02 } & \multicolumn{2}{|c|}{ 6.51E-02 } \\
\hline Limits (rem) & \multicolumn{2}{|c|}{0.5} & \multicolumn{2}{|c|}{1.5} & \multicolumn{2}{|c|}{0.5} & \multicolumn{2}{|c|}{1.5} \\
\hline
\end{tabular}


C-3. $250 \mathrm{MW}(\mathrm{t})$ Pebble Bed $700^{\circ} \mathrm{C}$

\section{C-3.1 Accident Scenario: Break in Helium Pressure Boundary}

\section{C-3.1.1 Source Term}

Table C-19. $250 \mathrm{MW}(\mathrm{t})$ pebble bed $700^{\circ} \mathrm{C}$ ROT-break in HPB-source term (curies).

\begin{tabular}{|c|c|c|c|c|c|c|c|c|}
\hline \multirow{2}{*}{ Nuclide } & \multicolumn{4}{|c|}{ Release to Environment Short Term } & \multicolumn{4}{|c|}{ Release to Environment Long Term } \\
\hline & DBA & $50 \%$ & Mean & $95 \%$ & DBA & $50 \%$ & Mean & $95 \%$ \\
\hline Xe-133 & $1.17 \mathrm{E}+01$ & $1.17 \mathrm{E}+01$ & $1.17 \mathrm{E}+01$ & $1.17 \mathrm{E}+01$ & $7.07 \mathrm{E}+01$ & $2.06 \mathrm{E}+01$ & $2.70 \mathrm{E}+01$ & $7.07 \mathrm{E}+01$ \\
\hline $\mathrm{Kr}-85$ & $6.07 \mathrm{E}-02$ & $6.07 \mathrm{E}-02$ & $6.07 \mathrm{E}-02$ & $6.07 \mathrm{E}-02$ & $4.80 \mathrm{E}-01$ & $1.40 \mathrm{E}-01$ & $1.84 \mathrm{E}-01$ & 4.80E-01 \\
\hline $\mathrm{Kr}-88$ & $6.10 \mathrm{E}+00$ & $6.10 \mathrm{E}+00$ & $6.10 \mathrm{E}+00$ & $6.10 \mathrm{E}+00$ & $1.98 \mathrm{E}-04$ & $5.74 \mathrm{E}-05$ & 7.53E-05 & $1.98 \mathrm{E}-04$ \\
\hline $\mathrm{I}-131$ & $3.51 \mathrm{E}-01$ & $1.68 \mathrm{E}-02$ & $4.95 \mathrm{E}-02$ & $1.88 \mathrm{E}-01$ & $4.37 \mathrm{E}+01$ & $1.22 \mathrm{E}+00$ & $2.59 \mathrm{E}+00$ & $9.28 \mathrm{E}+00$ \\
\hline I-133 & $5.59 \mathrm{E}-01$ & $2.80 \mathrm{E}-02$ & $8.21 \mathrm{E}-02$ & $3.12 \mathrm{E}-01$ & $1.78 \mathrm{E}+01$ & $4.99 \mathrm{E}-01$ & $1.04 \mathrm{E}+00$ & $3.69 \mathrm{E}+00$ \\
\hline Te-132 & 4.61E-01 & $2.15 \mathrm{E}-02$ & $6.54 \mathrm{E}-02$ & $2.47 \mathrm{E}-01$ & $4.44 \mathrm{E}+01$ & $1.27 \mathrm{E}+00$ & $2.65 \mathrm{E}+00$ & $9.48 \mathrm{E}+00$ \\
\hline Cs-137 & 7.97E-01 & $4.15 \mathrm{E}-02$ & $1.18 \mathrm{E}-01$ & $4.40 \mathrm{E}-01$ & $2.98 \mathrm{E}+00$ & 4.59E-02 & $1.36 \mathrm{E}-01$ & $5.26 \mathrm{E}-01$ \\
\hline Cs-134 & $1.22 \mathrm{E}-01$ & $6.39 \mathrm{E}-03$ & $1.79 \mathrm{E}-02$ & $6.63 \mathrm{E}-02$ & $3.28 \mathrm{E}+00$ & 5.04E-02 & $1.53 \mathrm{E}-01$ & $5.73 \mathrm{E}-01$ \\
\hline $\mathrm{Sr}-90$ & $1.36 \mathrm{E}-01$ & 7.07E-03 & $1.98 \mathrm{E}-02$ & $7.46 \mathrm{E}-02$ & $4.96 \mathrm{E}+00$ & $9.19 \mathrm{E}-02$ & $2.45 \mathrm{E}-01$ & $9.32 \mathrm{E}-01$ \\
\hline $\mathrm{Ag}-110 \mathrm{~m}$ & $1.99 \mathrm{E}+00$ & $9.91 \mathrm{E}-02$ & $2.80 \mathrm{E}-01$ & $1.09 \mathrm{E}+00$ & $1.76 \mathrm{E}+01$ & $2.42 \mathrm{E}-01$ & 7.93E-01 & $3.09 \mathrm{E}+00$ \\
\hline $\mathrm{Ag}-111$ & $3.75 \mathrm{E}+01$ & $1.90 \mathrm{E}+00$ & $5.32 \mathrm{E}+00$ & $2.08 \mathrm{E}+01$ & $1.45 \mathrm{E}+03$ & $2.17 \mathrm{E}+01$ & $6.82 \mathrm{E}+01$ & $2.59 \mathrm{E}+02$ \\
\hline Sb-125 & $1.09 \mathrm{E}-02$ & $5.31 \mathrm{E}-04$ & $1.52 \mathrm{E}-03$ & $5.78 \mathrm{E}-03$ & $4.36 \mathrm{E}-02$ & $6.65 \mathrm{E}-04$ & $1.90 \mathrm{E}-03$ & 7.47E-03 \\
\hline Ru-103 & $6.59 \mathrm{E}-02$ & $3.34 \mathrm{E}-03$ & $9.76 \mathrm{E}-03$ & $3.73 \mathrm{E}-02$ & $1.86 \mathrm{E}+01$ & $3.19 \mathrm{E}-01$ & $8.85 \mathrm{E}-01$ & $3.28 \mathrm{E}+00$ \\
\hline Ce-144 & $7.90 \mathrm{E}-01$ & $3.94 \mathrm{E}-02$ & $1.14 \mathrm{E}-01$ & 4.13E-01 & $1.27 \mathrm{E}+00$ & $2.14 \mathrm{E}-02$ & $6.13 \mathrm{E}-02$ & $2.26 \mathrm{E}-01$ \\
\hline La-140 & $6.07 \mathrm{E}-02$ & $2.88 \mathrm{E}-03$ & $8.54 \mathrm{E}-03$ & $3.24 \mathrm{E}-02$ & $7.30 \mathrm{E}-01$ & $1.29 \mathrm{E}-02$ & $3.54 \mathrm{E}-02$ & $1.32 \mathrm{E}-01$ \\
\hline $\mathrm{Pu}-239$ & $1.58 \mathrm{E}-05$ & $7.83 \mathrm{E}-07$ & $2.22 \mathrm{E}-06$ & $8.75 \mathrm{E}-06$ & $2.41 \mathrm{E}-05$ & $4.22 \mathrm{E}-07$ & $1.16 \mathrm{E}-06$ & 4.47E-06 \\
\hline
\end{tabular}




\section{C-3.1.2 Doses}

Table C-20. $250 \mathrm{MW}(\mathrm{t})$ pebble bed $700^{\circ} \mathrm{C}$ ROT_-break in HPB — Cases A and $\mathrm{B}-400 \mathrm{~m}$ from release (rem).

\begin{tabular}{|c|c|c|c|c|}
\hline \multirow[t]{2}{*}{ Nuclide } & \multicolumn{2}{|c|}{$\begin{array}{l}\text { Case A/EAB }(400 \mathrm{~m}) \\
\text { /TEDE }\end{array}$} & \multicolumn{2}{|c|}{$\begin{array}{c}\text { Case B/LPZ }(400 \mathrm{~m}) / \\
\text { TEDE }\end{array}$} \\
\hline & Short & Long & Short & Long \\
\hline Xe-133 & $5.48 \mathrm{E}-06$ & & $5.48 \mathrm{E}-06$ & $2.24 \mathrm{E}-05$ \\
\hline $\mathrm{Kr}-85$ & 2.37E-09 & & 2.37E-09 & $1.26 \mathrm{E}-08$ \\
\hline $\mathrm{Kr}-88$ & $1.86 \mathrm{E}-04$ & & $1.86 \mathrm{E}-04$ & $2.00 \mathrm{E}-09$ \\
\hline I-131 & 7.01E-04 & & 7.01E-04 & $4.98 \mathrm{E}-02$ \\
\hline I-133 & $1.72 \mathrm{E}-04$ & & $1.72 \mathrm{E}-04$ & $2.74 \mathrm{E}-03$ \\
\hline Te-132 & $3.44 \mathrm{E}-04$ & & $3.44 \mathrm{E}-04$ & $2.30 \mathrm{E}-02$ \\
\hline Cs- 137 & $1.61 \mathrm{E}-03$ & & $1.61 \mathrm{E}-03$ & $3.58 \mathrm{E}-03$ \\
\hline Cs-134 & $3.70 \mathrm{E}-04$ & & $3.70 \mathrm{E}-04$ & $6.37 \mathrm{E}-03$ \\
\hline Sr-90 & $1.38 \mathrm{E}-03$ & & $1.38 \mathrm{E}-03$ & $4.45 \mathrm{E}-02$ \\
\hline Ag-110m & $1.00 \mathrm{E}-02$ & & $1.00 \mathrm{E}-02$ & $5.65 \mathrm{E}-02$ \\
\hline Ag-111 & $1.14 \mathrm{E}-02$ & & $1.14 \mathrm{E}-02$ & $3.15 \mathrm{E}-01$ \\
\hline Sb-125 & $2.27 \mathrm{E}-06$ & & 2.27E-06 & $5.36 \mathrm{E}-06$ \\
\hline $\mathrm{Ru}-103$ & $3.40 \mathrm{E}-05$ & & $3.40 \mathrm{E}-05$ & $6.78 \mathrm{E}-03$ \\
\hline Ce-144 & $1.58 \mathrm{E}-02$ & & $1.58 \mathrm{E}-02$ & $1.64 \mathrm{E}-02$ \\
\hline La-140 & $3.13 \mathrm{E}-05$ & & $3.13 \mathrm{E}-05$ & $1.99 \mathrm{E}-04$ \\
\hline $\mathrm{Pu}-239$ & $1.82 \mathrm{E}-04$ & & $1.82 \mathrm{E}-04$ & $2.65 \mathrm{E}-04$ \\
\hline Sum & $4.22 \mathrm{E}-02$ & $0.00 E+00$ & 4.22E-02 & $5.25 \mathrm{E}-01$ \\
\hline TOTAL & \multicolumn{2}{|c|}{$4.22 \mathrm{E}-02$} & \multicolumn{2}{|c|}{$5.67 \mathrm{E}-01$} \\
\hline Limits (rem) & \multicolumn{4}{|c|}{25} \\
\hline
\end{tabular}


Table C-21. $250 \mathrm{MW}(\mathrm{t})$ pebble bed $700^{\circ} \mathrm{C}$ ROT_-break in HPB-Cases C and D-400 m from release (rem).

\begin{tabular}{|c|c|c|c|c|}
\hline \multirow[t]{2}{*}{ Nuclide } & \multicolumn{2}{|c|}{$\begin{array}{l}\text { CASE C/Inh, grndshine, } \\
\text { cldshine/TEDE }\end{array}$} & \multicolumn{2}{|c|}{$\begin{array}{l}\text { CASE D/Inh, grndshine, } \\
\text { cldshine/Thyroid }\end{array}$} \\
\hline & Short & Long & Short & Long \\
\hline Xe-133 & $2.19 \mathrm{E}-06$ & $5.13 \mathrm{E}-06$ & & \\
\hline $\mathrm{Kr}-85$ & $8.68 \mathrm{E}-10$ & $2.89 \mathrm{E}-09$ & & \\
\hline $\mathrm{Kr}-88$ & $8.30 \mathrm{E}-05$ & $3.34 \mathrm{E}-10$ & & \\
\hline $\mathrm{I}-131$ & $3.06 \mathrm{E}-05$ & $1.79 \mathrm{E}-03$ & $9.70 \mathrm{E}-04$ & $5.72 \mathrm{E}-02$ \\
\hline I-133 & $9.77 \mathrm{E}-06$ & $9.61 \mathrm{E}-05$ & $2.65 \mathrm{E}-04$ & $2.60 \mathrm{E}-03$ \\
\hline Te-132 & $1.75 \mathrm{E}-05$ & $7.48 \mathrm{E}-04$ & 2.82E-04 & $1.21 \mathrm{E}-02$ \\
\hline Cs-137 & 7.73E-05 & $1.04 \mathrm{E}-04$ & & \\
\hline Cs-134 & $1.68 \mathrm{E}-05$ & $1.66 \mathrm{E}-04$ & & \\
\hline Sr-90 & $8.65 \mathrm{E}-05$ & $1.27 \mathrm{E}-03$ & & \\
\hline $\mathrm{Ag}-110 \mathrm{~m}$ & $4.59 \mathrm{E}-04$ & $1.51 \mathrm{E}-03$ & & \\
\hline Ag-111 & $6.01 \mathrm{E}-04$ & $8.60 \mathrm{E}-03$ & & \\
\hline $\mathrm{Sb}-125$ & $1.01 \mathrm{E}-07$ & $1.38 \mathrm{E}-07$ & & \\
\hline $\mathrm{Ru}-103$ & $1.88 \mathrm{E}-06$ & $1.94 \mathrm{E}-04$ & & \\
\hline Ce-144 & $7.75 \mathrm{E}-04$ & 4.94E-04 & & \\
\hline La-140 & $1.40 \mathrm{E}-06$ & $5.27 \mathrm{E}-06$ & & \\
\hline $\mathrm{Pu}-239$ & $1.25 \mathrm{E}-05$ & 7.72E-06 & & \\
\hline Sum & 2.17E-03 & $1.50 \mathrm{E}-02$ & $1.52 \mathrm{E}-03$ & 7.19E-02 \\
\hline TOTAL & \multicolumn{2}{|c|}{$1.72 \mathrm{E}-02$} & \multicolumn{2}{|c|}{$7.34 \mathrm{E}-02$} \\
\hline Limits (rem) & \multicolumn{2}{|c|}{1} & \multicolumn{2}{|c|}{5} \\
\hline
\end{tabular}


Table C-22. $250 \mathrm{MW}(\mathrm{t})$ pebble bed $700^{\circ} \mathrm{C}$ ROT_-break in HPB - Cases E and F, infant and adult $-400 \mathrm{~m}$ from release (rem).

\begin{tabular}{|c|c|c|c|c|c|c|c|c|}
\hline \multirow[t]{2}{*}{ Nuclide } & \multicolumn{2}{|c|}{$\begin{array}{l}\text { CASE E/Ingestion - milk/ } \\
\text { EDE (infant) }\end{array}$} & \multicolumn{2}{|c|}{$\begin{array}{c}\text { CASE F/Ingestion - milk/ } \\
\text { Thyroid (infant) }\end{array}$} & \multicolumn{2}{|c|}{$\begin{array}{l}\text { CASE E/Ingestion - milk/ } \\
\text { EDE (adult) }\end{array}$} & \multicolumn{2}{|c|}{$\begin{array}{l}\text { CASE F/Ingestion - milk/ } \\
\text { Thyroid (adult) }\end{array}$} \\
\hline & Short & Long & Short & Long & Short & Long & Short & Long \\
\hline Xe-133 & - & - & - & - & - & - & - & - \\
\hline $\mathrm{Kr}-85$ & - & - & - & - & - & - & - & - \\
\hline Kr- 88 & - & - & - & - & - & - & - & - \\
\hline I-131 & $1.15 \mathrm{E}-03$ & $6.49 \mathrm{E}-02$ & $2.29 \mathrm{E}-02$ & $1.29 \mathrm{E}+00$ & $7.13 \mathrm{E}-05$ & $4.04 \mathrm{E}-03$ & $2.36 \mathrm{E}-03$ & $1.33 \mathrm{E}-01$ \\
\hline I-133 & $8.19 \mathrm{E}-05$ & $7.66 \mathrm{E}-04$ & $1.59 \mathrm{E}-03$ & $1.49 \mathrm{E}-02$ & $3.69 \mathrm{E}-06$ & $3.46 \mathrm{E}-05$ & $1.20 \mathrm{E}-04$ & $1.12 \mathrm{E}-03$ \\
\hline Te-132 & 4.09E-06 & $1.66 \mathrm{E}-04$ & $5.55 \mathrm{E}-05$ & $2.25 \mathrm{E}-03$ & $1.71 \mathrm{E}-07$ & $6.92 \mathrm{E}-06$ & $4.00 \mathrm{E}-06$ & $1.62 \mathrm{E}-04$ \\
\hline Cs-137 & $1.03 \mathrm{E}-03$ & $1.35 \mathrm{E}-03$ & $9.18 \mathrm{E}-04$ & $1.21 \mathrm{E}-03$ & $5.21 \mathrm{E}-04$ & $6.83 \mathrm{E}-04$ & $4.86 \mathrm{E}-04$ & $6.38 \mathrm{E}-04$ \\
\hline Cs-134 & $1.78 \mathrm{E}-04$ & $1.72 \mathrm{E}-03$ & $1.76 \mathrm{E}-04$ & $1.71 \mathrm{E}-03$ & $1.08 \mathrm{E}-04$ & $1.05 \mathrm{E}-03$ & $9.63 \mathrm{E}-05$ & $9.36 \mathrm{E}-04$ \\
\hline $\mathrm{Sr}-90$ & $3.27 \mathrm{E}-04$ & $4.60 \mathrm{E}-03$ & $1.71 \mathrm{E}-05$ & $2.39 \mathrm{E}-04$ & $4.43 \mathrm{E}-05$ & $6.19 \mathrm{E}-04$ & $1.73 \mathrm{E}-06$ & $2.43 \mathrm{E}-05$ \\
\hline Ag-110m & $5.31 \mathrm{E}-03$ & $1.70 \mathrm{E}-02$ & $1.43 \mathrm{E}-03$ & 4.60E-03 & $5.09 \mathrm{E}-04$ & $1.64 \mathrm{E}-03$ & $3.16 \mathrm{E}-05$ & $1.01 \mathrm{E}-04$ \\
\hline Ag-111 & $1.78 \mathrm{E}-02$ & $2.45 \mathrm{E}-01$ & $4.81 \mathrm{E}-04$ & $6.63 \mathrm{E}-03$ & $1.35 \mathrm{E}-03$ & $1.86 \mathrm{E}-02$ & $7.39 \mathrm{E}-06$ & $1.02 \mathrm{E}-04$ \\
\hline $\mathrm{Sb}-125$ & $1.36 \mathrm{E}-07$ & $1.94 \mathrm{E}-07$ & $1.43 \mathrm{E}-07$ & $2.04 \mathrm{E}-07$ & 7.99E-09 & $1.14 \mathrm{E}-08$ & $4.01 \mathrm{E}-10$ & $5.71 \mathrm{E}-10$ \\
\hline Ru-103 & $1.08 \mathrm{E}-09$ & $1.11 \mathrm{E}-07$ & $1.69 \mathrm{E}-10$ & $1.72 \mathrm{E}-08$ & $9.96 \mathrm{E}-11$ & $1.02 \mathrm{E}-08$ & $7.54 \mathrm{E}-12$ & $7.69 \mathrm{E}-10$ \\
\hline Ce-144 & $6.08 \mathrm{E}-06$ & $3.72 \mathrm{E}-06$ & 7.72E-08 & 4.72E-08 & $4.12 \mathrm{E}-07$ & $2.52 \mathrm{E}-07$ & $3.72 \mathrm{E}-10$ & $2.28 \mathrm{E}-10$ \\
\hline La-140 & $1.23 \mathrm{E}-08$ & $4.56 \mathrm{E}-08$ & $7.88 \mathrm{E}-11$ & $2.92 \mathrm{E}-10$ & $1.14 \mathrm{E}-09$ & $4.21 \mathrm{E}-09$ & $3.20 \mathrm{E}-12$ & $1.19 \mathrm{E}-11$ \\
\hline Pu-239 & 4.24E-11 & $2.52 \mathrm{E}-11$ & $5.58 \mathrm{E}-12$ & $3.31 \mathrm{E}-12$ & $1.13 \mathrm{E}-13$ & $6.70 \mathrm{E}-14$ & $6.04 \mathrm{E}-19$ & $3.59 \mathrm{E}-19$ \\
\hline Sum & 2.58E-02 & $3.35 \mathrm{E}-01$ & $2.75 \mathrm{E}-02$ & $1.32 \mathrm{E}+00$ & $2.61 \mathrm{E}-03$ & $2.67 \mathrm{E}-02$ & $3.11 \mathrm{E}-03$ & $1.36 \mathrm{E}-01$ \\
\hline TOTAL & \multicolumn{2}{|c|}{$3.61 \mathrm{E}-01$} & \multicolumn{2}{|c|}{$1.35 \mathrm{E}+00$} & \multicolumn{2}{|c|}{$2.93 \mathrm{E}-02$} & \multicolumn{2}{|c|}{$1.39 \mathrm{E}-01$} \\
\hline Limits (rem) & \multicolumn{2}{|c|}{0.5} & \multicolumn{2}{|c|}{1.5} & \multicolumn{2}{|c|}{0.5} & \multicolumn{2}{|c|}{1.5} \\
\hline
\end{tabular}


Table C-23. $250 \mathrm{MW}(\mathrm{t})$ pebble bed $700^{\circ} \mathrm{C}$ ROT_-break in HPB - Cases E and F, infant and adult $-800 \mathrm{~m}$ from release (rem).

\begin{tabular}{|c|c|c|c|c|c|c|c|c|}
\hline \multirow[t]{2}{*}{ Nuclide } & \multicolumn{2}{|c|}{$\begin{array}{l}\text { CASE E/Ingestion - milk/ } \\
\text { EDE (infant) }\end{array}$} & \multicolumn{2}{|c|}{$\begin{array}{l}\text { CASE F/Ingestion - milk/ } \\
\text { Thyroid (infant) }\end{array}$} & \multicolumn{2}{|c|}{$\begin{array}{l}\text { CASE E/Ingestion - milk/ } \\
\text { EDE (adult) }\end{array}$} & \multicolumn{2}{|c|}{$\begin{array}{l}\text { CASE F/Ingestion - milk/ } \\
\text { Thyroid (adult) }\end{array}$} \\
\hline & Short & Long & Short & Long & Short & Long & Short & Long \\
\hline Xe-133 & - & - & - & - & - & - & - & - \\
\hline $\mathrm{Kr}-85$ & - & - & - & - & - & - & - & - \\
\hline $\mathrm{Kr}-88$ & - & - & - & - & - & - & - & - \\
\hline I-131 & 4.23E-04 & $2.42 \mathrm{E}-02$ & $8.41 \mathrm{E}-03$ & 4.81E-01 & $2.62 \mathrm{E}-05$ & $1.50 \mathrm{E}-03$ & $8.66 \mathrm{E}-04$ & 4.97E-02 \\
\hline I-133 & $3.00 \mathrm{E}-05$ & $2.84 \mathrm{E}-04$ & $5.83 \mathrm{E}-04$ & $5.54 \mathrm{E}-03$ & $1.35 \mathrm{E}-06$ & $1.28 \mathrm{E}-05$ & $4.38 \mathrm{E}-05$ & $4.16 \mathrm{E}-04$ \\
\hline Te-132 & $1.50 \mathrm{E}-06$ & $6.18 \mathrm{E}-05$ & $2.04 \mathrm{E}-05$ & $8.38 \mathrm{E}-04$ & $6.26 \mathrm{E}-08$ & $2.58 \mathrm{E}-06$ & $1.46 \mathrm{E}-06$ & $6.04 \mathrm{E}-05$ \\
\hline Cs-137 & $3.77 \mathrm{E}-04$ & $5.01 \mathrm{E}-04$ & 3.37E-04 & 4.49E-04 & $1.91 \mathrm{E}-04$ & $2.54 \mathrm{E}-04$ & $1.78 \mathrm{E}-04$ & $2.37 \mathrm{E}-04$ \\
\hline Cs-134 & $6.54 \mathrm{E}-05$ & $6.43 \mathrm{E}-04$ & $6.45 \mathrm{E}-05$ & $6.35 \mathrm{E}-04$ & $3.98 \mathrm{E}-05$ & $3.91 \mathrm{E}-04$ & $3.54 \mathrm{E}-05$ & $3.48 \mathrm{E}-04$ \\
\hline Sr-90 & $1.20 \mathrm{E}-04$ & $1.71 \mathrm{E}-03$ & $6.25 \mathrm{E}-06$ & $8.88 \mathrm{E}-05$ & $1.62 \mathrm{E}-05$ & $2.30 \mathrm{E}-04$ & $6.35 \mathrm{E}-07$ & $9.00 \mathrm{E}-06$ \\
\hline $\mathrm{Ag}-110 \mathrm{~m}$ & $1.94 \mathrm{E}-03$ & $6.34 \mathrm{E}-03$ & $5.23 \mathrm{E}-04$ & $1.70 \mathrm{E}-03$ & $1.87 \mathrm{E}-04$ & $6.10 \mathrm{E}-04$ & $1.16 \mathrm{E}-05$ & $3.78 \mathrm{E}-05$ \\
\hline Ag-111 & $6.54 \mathrm{E}-03$ & $9.14 \mathrm{E}-02$ & $1.77 \mathrm{E}-04$ & $2.47 \mathrm{E}-03$ & 4.97E-04 & $6.96 \mathrm{E}-03$ & $2.71 \mathrm{E}-06$ & $3.79 \mathrm{E}-05$ \\
\hline Sb-125 & $4.98 \mathrm{E}-08$ & 7.18E-08 & $5.21 \mathrm{E}-08$ & $7.50 \mathrm{E}-08$ & $2.92 \mathrm{E}-09$ & $4.21 \mathrm{E}-09$ & $1.47 \mathrm{E}-10$ & $2.11 \mathrm{E}-10$ \\
\hline Ru-103 & $3.98 \mathrm{E}-10$ & $4.12 \mathrm{E}-08$ & $6.20 \mathrm{E}-11$ & $6.41 \mathrm{E}-09$ & $3.66 \mathrm{E}-11$ & $3.79 \mathrm{E}-09$ & $2.77 \mathrm{E}-12$ & $2.87 \mathrm{E}-10$ \\
\hline Ce-144 & $2.23 \mathrm{E}-06$ & $1.38 \mathrm{E}-06$ & 2.82E-08 & $1.75 \mathrm{E}-08$ & $1.51 \mathrm{E}-07$ & $9.38 \mathrm{E}-08$ & $1.37 \mathrm{E}-10$ & $8.46 \mathrm{E}-11$ \\
\hline La-140 & $4.51 \mathrm{E}-09$ & $1.69 \mathrm{E}-08$ & $2.89 \mathrm{E}-11$ & $1.09 \mathrm{E}-10$ & 4.19E-10 & $1.57 \mathrm{E}-09$ & $1.17 \mathrm{E}-12$ & 4. $42 \mathrm{E}-12$ \\
\hline $\mathrm{Pu}-239$ & $1.55 \mathrm{E}-11$ & $9.37 \mathrm{E}-12$ & $2.04 \mathrm{E}-12$ & $1.23 \mathrm{E}-12$ & 4.13E-14 & $2.48 \mathrm{E}-14$ & $2.21 \mathrm{E}-19$ & $1.33 \mathrm{E}-19$ \\
\hline Sum & $9.50 \mathrm{E}-03$ & $1.25 \mathrm{E}-01$ & $1.01 \mathrm{E}-02$ & $4.93 \mathrm{E}-01$ & 9.59E-04 & $9.96 \mathrm{E}-03$ & $1.14 \mathrm{E}-03$ & $5.08 \mathrm{E}-02$ \\
\hline TOTAL & \multicolumn{2}{|c|}{ 1.35E-01 } & \multicolumn{2}{|c|}{ 5.03E-01 } & \multicolumn{2}{|c|}{ 1.09E-02 } & \multicolumn{2}{|c|}{$5.20 \mathrm{E}-02$} \\
\hline Limits (rem) & \multicolumn{2}{|c|}{0.5} & \multicolumn{2}{|c|}{1.5} & \multicolumn{2}{|c|}{0.5} & \multicolumn{2}{|c|}{1.5} \\
\hline
\end{tabular}


Table C-24. $250 \mathrm{MW}(\mathrm{t})$ pebble bed $700^{\circ} \mathrm{C}$ ROT-break in HPB-Cases E and F, infant and adult - $1600 \mathrm{~m}$ from release (rem).

\begin{tabular}{|c|c|c|c|c|c|c|c|c|}
\hline \multirow[t]{2}{*}{ Nuclide } & \multicolumn{2}{|c|}{$\begin{array}{c}\text { CASE E/Ingestion - milk/ } \\
\text { EDE (infant) }\end{array}$} & \multicolumn{2}{|c|}{$\begin{array}{c}\text { CASE F/Ingestion - milk/ } \\
\text { Thyroid (infant) }\end{array}$} & \multicolumn{2}{|c|}{$\begin{array}{l}\text { CASE E/Ingestion - milk/ } \\
\text { EDE (adult) }\end{array}$} & \multicolumn{2}{|c|}{$\begin{array}{c}\text { CASE F/Ingestion - milk/ } \\
\text { Thyroid (adult) }\end{array}$} \\
\hline & Short & Long & Short & Long & Short & Long & Short & Long \\
\hline Xe-133 & - & - & - & - & - & - & - & - \\
\hline $\mathrm{Kr}-85$ & - & - & - & - & - & - & - & - \\
\hline $\mathrm{Kr}-88$ & - & - & - & - & - & - & - & - \\
\hline I-131 & $1.54 \mathrm{E}-04$ & $9.13 \mathrm{E}-03$ & $3.06 \mathrm{E}-03$ & $1.82 \mathrm{E}-01$ & $9.55 \mathrm{E}-06$ & $5.69 \mathrm{E}-04$ & $3.16 \mathrm{E}-04$ & $1.88 \mathrm{E}-02$ \\
\hline I-133 & $1.08 \mathrm{E}-05$ & $1.06 \mathrm{E}-04$ & $2.11 \mathrm{E}-04$ & $2.08 \mathrm{E}-03$ & $4.89 \mathrm{E}-07$ & $4.81 \mathrm{E}-06$ & $1.58 \mathrm{E}-05$ & $1.56 \mathrm{E}-04$ \\
\hline Te-132 & $5.48 \mathrm{E}-07$ & $2.34 \mathrm{E}-05$ & $7.45 \mathrm{E}-06$ & $3.15 \mathrm{E}-04$ & $2.28 \mathrm{E}-08$ & $9.73 \mathrm{E}-07$ & $5.34 \mathrm{E}-07$ & $2.28 \mathrm{E}-05$ \\
\hline Cs-137 & $1.37 \mathrm{E}-04$ & $1.90 \mathrm{E}-04$ & $1.23 \mathrm{E}-04$ & $1.69 \mathrm{E}-04$ & $6.98 \mathrm{E}-05$ & $9.60 \mathrm{E}-05$ & $6.51 \mathrm{E}-05$ & $8.96 \mathrm{E}-05$ \\
\hline Cs-134 & $2.38 \mathrm{E}-05$ & $2.43 \mathrm{E}-04$ & $2.36 \mathrm{E}-05$ & $2.40 \mathrm{E}-04$ & $1.45 \mathrm{E}-05$ & $1.48 \mathrm{E}-04$ & $1.29 \mathrm{E}-05$ & $1.31 \mathrm{E}-04$ \\
\hline Sr-90 & $4.39 \mathrm{E}-05$ & $6.43 \mathrm{E}-04$ & $2.28 \mathrm{E}-06$ & $3.35 \mathrm{E}-05$ & $5.89 \mathrm{E}-06$ & $8.66 \mathrm{E}-05$ & $2.32 \mathrm{E}-07$ & $3.40 \mathrm{E}-06$ \\
\hline Ag-110m & $7.08 \mathrm{E}-04$ & $2.39 \mathrm{E}-03$ & $1.91 \mathrm{E}-04$ & $6.43 \mathrm{E}-04$ & $6.82 \mathrm{E}-05$ & $2.30 \mathrm{E}-04$ & $4.22 \mathrm{E}-06$ & $1.43 \mathrm{E}-05$ \\
\hline Ag-111 & $2.38 \mathrm{E}-03$ & $3.45 \mathrm{E}-02$ & $6.44 \mathrm{E}-05$ & $9.35 \mathrm{E}-04$ & $1.81 \mathrm{E}-04$ & $2.63 \mathrm{E}-03$ & $9.89 \mathrm{E}-07$ & $1.43 \mathrm{E}-05$ \\
\hline $\mathrm{Sb}-125$ & $1.81 \mathrm{E}-08$ & $2.70 \mathrm{E}-08$ & $1.90 \mathrm{E}-08$ & $2.80 \mathrm{E}-08$ & $1.06 \mathrm{E}-09$ & $1.58 \mathrm{E}-09$ & $5.35 \mathrm{E}-11$ & $7.94 \mathrm{E}-11$ \\
\hline Ru-103 & $1.45 \mathrm{E}-10$ & $1.56 \mathrm{E}-08$ & $2.27 \mathrm{E}-11$ & $2.43 \mathrm{E}-09$ & $1.34 \mathrm{E}-11$ & $1.43 \mathrm{E}-09$ & $1.02 \mathrm{E}-12$ & $1.08 \mathrm{E}-10$ \\
\hline $\mathrm{Ce}-144$ & $8.13 \mathrm{E}-07$ & $5.21 \mathrm{E}-07$ & $1.03 \mathrm{E}-08$ & $6.62 \mathrm{E}-09$ & $5.51 \mathrm{E}-08$ & $3.53 \mathrm{E}-08$ & $4.97 \mathrm{E}-11$ & $3.19 \mathrm{E}-11$ \\
\hline La-140 & $1.64 \mathrm{E}-09$ & 6.37E-09 & $1.05 \mathrm{E}-11$ & $4.10 \mathrm{E}-11$ & $1.52 \mathrm{E}-10$ & $5.91 \mathrm{E}-10$ & $4.27 \mathrm{E}-13$ & $1.66 \mathrm{E}-12$ \\
\hline Pu-239 & $5.66 \mathrm{E}-12$ & $3.52 \mathrm{E}-12$ & $7.44 \mathrm{E}-13$ & $4.62 \mathrm{E}-13$ & $1.50 \mathrm{E}-14$ & $9.34 \mathrm{E}-15$ & $8.04 \mathrm{E}-20$ & $5.00 \mathrm{E}-20$ \\
\hline Sum & $3.46 \mathrm{E}-03$ & 4.72E-02 & $3.69 \mathrm{E}-03$ & $1.86 \mathrm{E}-01$ & $3.50 \mathrm{E}-04$ & $3.76 \mathrm{E}-03$ & $4.16 \mathrm{E}-04$ & $1.92 \mathrm{E}-02$ \\
\hline TOTAL & \multicolumn{2}{|c|}{$5.07 E-02$} & \multicolumn{2}{|c|}{$1.90 \mathrm{E}-01$} & \multicolumn{2}{|c|}{$4.11 \mathrm{E}-03$} & \multicolumn{2}{|c|}{$1.96 \mathrm{E}-02$} \\
\hline Limits (rem) & \multicolumn{2}{|c|}{0.5} & \multicolumn{2}{|c|}{1.5} & \multicolumn{2}{|c|}{0.5} & \multicolumn{2}{|c|}{1.5} \\
\hline
\end{tabular}




\section{C-3.2 Accident Scenario: Water Ingress Event}

\section{B-1.1.1 Source Term}

Table C-25. $250 \mathrm{MW}(\mathrm{t})$ pebble bed $700^{\circ} \mathrm{C}$ ROT-water ingress-source term (curies).

\begin{tabular}{|c|c|c|c|c|c|c|c|c|}
\hline \multirow{2}{*}{ Nuclide } & \multicolumn{4}{|c|}{ Release to Environment Short Term } & \multicolumn{4}{|c|}{ Release to Environment Long Term } \\
\hline & DBA & $50 \%$ & Mean & $95 \%$ & DBA & $50 \%$ & Mean & $95 \%$ \\
\hline Xe-133 & $1.16 \mathrm{E}+01$ & $1.16 \mathrm{E}+01$ & $1.16 \mathrm{E}+01$ & $1.16 \mathrm{E}+01$ & $1.85 \mathrm{E}+02$ & $4.58 \mathrm{E}+01$ & $6.43 \mathrm{E}+01$ & $1.85 \mathrm{E}+02$ \\
\hline $\mathrm{Kr}-85$ & $6.26 \mathrm{E}-02$ & $6.26 \mathrm{E}-02$ & $6.26 \mathrm{E}-02$ & $6.26 \mathrm{E}-02$ & $1.31 \mathrm{E}+00$ & $3.08 \mathrm{E}-01$ & $4.42 \mathrm{E}-01$ & $1.31 \mathrm{E}+00$ \\
\hline $\mathrm{Kr}-88$ & $6.00 \mathrm{E}+00$ & $6.00 \mathrm{E}+00$ & $6.00 \mathrm{E}+00$ & $6.00 \mathrm{E}+00$ & 5.33E-04 & $1.26 \mathrm{E}-04$ & $1.82 \mathrm{E}-04$ & $5.33 \mathrm{E}-04$ \\
\hline $\mathrm{I}-131$ & $6.41 \mathrm{E}+00$ & $3.21 \mathrm{E}-01$ & $5.42 \mathrm{E}-01$ & $1.80 \mathrm{E}+00$ & $2.40 \mathrm{E}+02$ & $1.33 \mathrm{E}+00$ & $2.80 \mathrm{E}+00$ & $1.02 \mathrm{E}+01$ \\
\hline I-133 & $1.15 \mathrm{E}+01$ & $5.76 \mathrm{E}-01$ & $9.78 \mathrm{E}-01$ & $3.27 \mathrm{E}+00$ & $9.70 \mathrm{E}+01$ & $5.32 \mathrm{E}-01$ & $1.20 \mathrm{E}+00$ & $4.41 \mathrm{E}+00$ \\
\hline Te-132 & $8.80 \mathrm{E}+00$ & $4.29 \mathrm{E}-01$ & $7.51 \mathrm{E}-01$ & $2.49 \mathrm{E}+00$ & $2.39 \mathrm{E}+02$ & $1.37 \mathrm{E}+00$ & $2.95 \mathrm{E}+00$ & $1.10 \mathrm{E}+01$ \\
\hline Cs-137 & $1.63 \mathrm{E}+01$ & 8.22E-01 & $1.40 \mathrm{E}+00$ & $4.64 \mathrm{E}+00$ & $2.84 \mathrm{E}+01$ & $1.03 \mathrm{E}-01$ & $2.89 \mathrm{E}-01$ & $1.10 \mathrm{E}+00$ \\
\hline Cs-134 & $2.62 \mathrm{E}+00$ & $1.30 \mathrm{E}-01$ & $2.26 \mathrm{E}-01$ & 7.49E-01 & $3.12 \mathrm{E}+01$ & $1.17 \mathrm{E}-01$ & $3.15 \mathrm{E}-01$ & $1.23 \mathrm{E}+00$ \\
\hline Sr-90 & $2.78 \mathrm{E}+00$ & $1.37 \mathrm{E}-01$ & $2.31 \mathrm{E}-01$ & $7.50 \mathrm{E}-01$ & $5.30 \mathrm{E}+01$ & $1.83 \mathrm{E}-01$ & 5.38E-01 & $2.00 \mathrm{E}+00$ \\
\hline $\mathrm{Ag}-110 \mathrm{~m}$ & $3.94 \mathrm{E}+01$ & $1.95 \mathrm{E}+00$ & $3.30 \mathrm{E}+00$ & $1.11 \mathrm{E}+01$ & $6.43 \mathrm{E}+01$ & $2.45 \mathrm{E}-01$ & $6.59 \mathrm{E}-01$ & $2.53 \mathrm{E}+00$ \\
\hline Ag-111 & $7.93 \mathrm{E}+02$ & $3.95 \mathrm{E}+01$ & $6.81 \mathrm{E}+01$ & $2.29 \mathrm{E}+02$ & $5.50 \mathrm{E}+03$ & $2.11 \mathrm{E}+01$ & $5.67 \mathrm{E}+01$ & $2.12 \mathrm{E}+02$ \\
\hline $\mathrm{Sb}-125$ & $2.11 \mathrm{E}-01$ & $1.06 \mathrm{E}-02$ & $1.82 \mathrm{E}-02$ & 5.99E-02 & $2.48 \mathrm{E}-01$ & $8.10 \mathrm{E}-04$ & $2.41 \mathrm{E}-03$ & $9.48 \mathrm{E}-03$ \\
\hline Ru-103 & $1.35 \mathrm{E}+00$ & $6.72 \mathrm{E}-02$ & $1.14 \mathrm{E}-01$ & $3.77 \mathrm{E}-01$ & $6.65 \mathrm{E}+01$ & $3.17 \mathrm{E}-01$ & $7.55 \mathrm{E}-01$ & $2.79 \mathrm{E}+00$ \\
\hline $\mathrm{Ce}-144$ & $1.61 \mathrm{E}+01$ & $8.16 \mathrm{E}-01$ & $1.37 \mathrm{E}+00$ & $4.56 \mathrm{E}+00$ & $4.53 E+00$ & $2.14 \mathrm{E}-02$ & $5.23 \mathrm{E}-02$ & $1.95 \mathrm{E}-01$ \\
\hline La-140 & $1.23 \mathrm{E}+00$ & $6.09 \mathrm{E}-02$ & $1.02 \mathrm{E}-01$ & $3.44 \mathrm{E}-01$ & $2.70 \mathrm{E}+00$ & $1.24 \mathrm{E}-02$ & $3.15 \mathrm{E}-02$ & $1.16 \mathrm{E}-01$ \\
\hline $\mathrm{Pu}-239$ & $3.20 \mathrm{E}-04$ & $1.58 \mathrm{E}-05$ & $2.70 \mathrm{E}-05$ & 8.93E-05 & $8.78 \mathrm{E}-05$ & $4.12 \mathrm{E}-07$ & $1.01 \mathrm{E}-06$ & $3.77 \mathrm{E}-06$ \\
\hline
\end{tabular}




\section{C-3.2.1 Doses}

Table C-26. $250 \mathrm{MW}(\mathrm{t})$ pebble bed $700^{\circ} \mathrm{C}$ ROT—water ingress - Cases A and B- $400 \mathrm{~m}$ from release (rem).

\begin{tabular}{|c|c|c|c|c|}
\hline \multirow[t]{2}{*}{ Nuclide } & \multicolumn{2}{|c|}{$\begin{array}{c}\text { Case A/EAB } \\
(400 \mathrm{~m}) / \mathrm{TEDE}\end{array}$} & \multicolumn{2}{|c|}{$\begin{array}{c}\text { Case B/LPZ } \\
(400 \mathrm{~m}) / \mathrm{TEDE}\end{array}$} \\
\hline & Short & Long & Short & Long \\
\hline $\mathrm{Xe}-133$ & $5.42 \mathrm{E}-06$ & & $5.42 \mathrm{E}-06$ & $5.86 \mathrm{E}-05$ \\
\hline $\mathrm{Kr}-85$ & $2.45 \mathrm{E}-09$ & & $2.45 \mathrm{E}-09$ & $3.42 \mathrm{E}-08$ \\
\hline $\mathrm{Kr}-88$ & $1.83 \mathrm{E}-04$ & & $1.83 \mathrm{E}-04$ & $5.38 \mathrm{E}-09$ \\
\hline $\mathrm{I}-131$ & $1.28 \mathrm{E}-02$ & & $1.28 \mathrm{E}-02$ & $2.74 \mathrm{E}-01$ \\
\hline $\mathrm{I}-133$ & $3.54 \mathrm{E}-03$ & & $3.54 \mathrm{E}-03$ & $1.49 \mathrm{E}-02$ \\
\hline Te-132 & $6.56 \mathrm{E}-03$ & & $6.56 \mathrm{E}-03$ & $1.24 \mathrm{E}-01$ \\
\hline Cs-137 & $3.29 \mathrm{E}-02$ & & $3.29 \mathrm{E}-02$ & $3.41 \mathrm{E}-02$ \\
\hline Cs-134 & $7.92 \mathrm{E}-03$ & & $7.92 \mathrm{E}-03$ & $6.05 \mathrm{E}-02$ \\
\hline Sr-90 & $2.83 \mathrm{E}-02$ & & 2.83E-02 & $4.76 \mathrm{E}-01$ \\
\hline Ag-110m & $1.98 \mathrm{E}-01$ & & $1.98 \mathrm{E}-01$ & $2.06 \mathrm{E}-01$ \\
\hline Ag-111 & $2.40 \mathrm{E}-01$ & & $2.40 \mathrm{E}-01$ & $1.20 \mathrm{E}+00$ \\
\hline $\mathrm{Sb}-125$ & $4.40 \mathrm{E}-05$ & & $4.40 \mathrm{E}-05$ & $3.05 \mathrm{E}-05$ \\
\hline Ru-103 & $6.98 \mathrm{E}-04$ & & $6.98 \mathrm{E}-04$ & $2.43 \mathrm{E}-02$ \\
\hline Ce-144 & $3.22 \mathrm{E}-01$ & & $3.22 \mathrm{E}-01$ & $5.84 \mathrm{E}-02$ \\
\hline La-140 & $6.36 \mathrm{E}-04$ & & $6.36 \mathrm{E}-04$ & 7.33E-04 \\
\hline $\mathrm{Pu}-239$ & $3.68 \mathrm{E}-03$ & & $3.68 \mathrm{E}-03$ & $9.66 \mathrm{E}-04$ \\
\hline Sum & 8.58E-01 & $0.00 \mathrm{E}+00$ & 8.58E-01 & $2.47 \mathrm{E}+00$ \\
\hline TOTAL & \multicolumn{2}{|c|}{$8.58 \mathrm{E}-01$} & \multicolumn{2}{|c|}{$3.33 \mathrm{E}+00$} \\
\hline Limits (rem) & \multicolumn{4}{|c|}{2} \\
\hline
\end{tabular}


Table C-27. $250 \mathrm{MW}(\mathrm{t})$ pebble bed $700^{\circ} \mathrm{C}$ ROT—water ingress - Cases C and D- $400 \mathrm{~m}$ from release (rem).

\begin{tabular}{|c|c|c|c|c|}
\hline \multirow[t]{2}{*}{ Nuclide } & \multicolumn{2}{|c|}{$\begin{array}{l}\text { CASE C/Inh, grndshine, } \\
\text { cldshine/TEDE }\end{array}$} & \multicolumn{2}{|c|}{$\begin{array}{l}\text { CASE D/Inh, grndshine, } \\
\text { cldshine/Thyroid }\end{array}$} \\
\hline & Short & Long & Short & Long \\
\hline Xe-133 & $2.17 \mathrm{E}-06$ & $1.22 \mathrm{E}-05$ & & \\
\hline $\mathrm{Kr}-85$ & $8.96 \mathrm{E}-10$ & $6.94 \mathrm{E}-09$ & & \\
\hline $\mathrm{Kr}-88$ & $8.16 \mathrm{E}-05$ & $8.07 \mathrm{E}-10$ & & \\
\hline $\mathrm{I}-131$ & $3.35 \mathrm{E}-04$ & $1.94 \mathrm{E}-03$ & $1.06 \mathrm{E}-02$ & $6.19 \mathrm{E}-02$ \\
\hline I-133 & $1.16 \mathrm{E}-04$ & $1.11 \mathrm{E}-04$ & $3.16 \mathrm{E}-03$ & $3.00 \mathrm{E}-03$ \\
\hline Te-132 & $2.01 \mathrm{E}-04$ & $8.32 \mathrm{E}-04$ & $3.24 \mathrm{E}-03$ & $1.35 \mathrm{E}-02$ \\
\hline Cs-137 & $9.13 \mathrm{E}-04$ & $2.19 \mathrm{E}-04$ & & \\
\hline Cs-134 & $2.13 \mathrm{E}-04$ & $3.44 \mathrm{E}-04$ & & \\
\hline Sr-90 & $1.01 \mathrm{E}-03$ & $2.80 \mathrm{E}-03$ & & \\
\hline $\mathrm{Ag}-110 \mathrm{~m}$ & $5.42 \mathrm{E}-03$ & $1.25 \mathrm{E}-03$ & & \\
\hline Ag-111 & $7.69 \mathrm{E}-03$ & $7.15 \mathrm{E}-03$ & & \\
\hline $\mathrm{Sb}-125$ & $1.21 \mathrm{E}-06$ & $1.75 \mathrm{E}-07$ & & \\
\hline Ru-103 & $2.20 \mathrm{E}-05$ & $1.65 \mathrm{E}-04$ & & \\
\hline $\mathrm{Ce}-144$ & $9.34 \mathrm{E}-03$ & $4.22 \mathrm{E}-04$ & & \\
\hline La-140 & $1.68 \mathrm{E}-05$ & $4.69 \mathrm{E}-06$ & & \\
\hline $\mathrm{Pu}-239$ & $1.51 \mathrm{E}-04$ & $6.72 \mathrm{E}-06$ & & \\
\hline Sum & $2.55 \mathrm{E}-02$ & $1.53 \mathrm{E}-02$ & $1.70 \mathrm{E}-02$ & $7.84 \mathrm{E}-02$ \\
\hline TOTAL & \multicolumn{2}{|c|}{ 4.08E-02 } & \multicolumn{2}{|c|}{$9.54 \mathrm{E}-02$} \\
\hline Limits (rem) & \multicolumn{2}{|c|}{1} & \multicolumn{2}{|c|}{5} \\
\hline
\end{tabular}


Table C-28. $250 \mathrm{MW}(\mathrm{t})$ Pebble Bed $700^{\circ} \mathrm{C}$ ROT - water ingress-Cases E and F, infant and adult $-400 \mathrm{~m}$ from release (rem).

\begin{tabular}{|c|c|c|c|c|c|c|c|c|}
\hline \multirow[t]{2}{*}{ Nuclide } & \multicolumn{2}{|c|}{$\begin{array}{l}\text { CASE E/Ingestion - milk/ } \\
\text { EDE (infant) }\end{array}$} & \multicolumn{2}{|c|}{$\begin{array}{c}\text { CASE F/Ingestion - milk/ } \\
\text { Thyroid (infant) }\end{array}$} & \multicolumn{2}{|c|}{$\begin{array}{l}\text { CASE E/Ingestion - milk/ } \\
\text { EDE (adult) }\end{array}$} & \multicolumn{2}{|c|}{$\begin{array}{l}\text { CASE F/Ingestion - milk/ } \\
\text { Thyroid (adult) }\end{array}$} \\
\hline & Short & Long & Short & Long & Short & Long & Short & Long \\
\hline Xe-133 & - & - & - & - & - & - & - & - \\
\hline $\mathrm{Kr}-85$ & - & - & - & - & - & - & - & - \\
\hline Kr- 88 & - & - & - & - & - & - & - & - \\
\hline I-131 & $1.26 \mathrm{E}-02$ & 7.03E-02 & $2.50 \mathrm{E}-01$ & $1.40 \mathrm{E}+00$ & $7.80 \mathrm{E}-04$ & $4.37 \mathrm{E}-03$ & $2.58 \mathrm{E}-02$ & $1.44 \mathrm{E}-01$ \\
\hline I-133 & $9.75 \mathrm{E}-04$ & $8.82 \mathrm{E}-04$ & $1.90 \mathrm{E}-02$ & $1.71 \mathrm{E}-02$ & $4.39 \mathrm{E}-05$ & $3.98 \mathrm{E}-05$ & $1.43 \mathrm{E}-03$ & $1.29 \mathrm{E}-03$ \\
\hline Te-132 & 4.70E-05 & $1.85 \mathrm{E}-04$ & $6.38 \mathrm{E}-04$ & $2.51 \mathrm{E}-03$ & $1.96 \mathrm{E}-06$ & $7.70 \mathrm{E}-06$ & $4.59 \mathrm{E}-05$ & $1.80 \mathrm{E}-04$ \\
\hline Cs-137 & $1.21 \mathrm{E}-02$ & $2.85 \mathrm{E}-03$ & $1.08 \mathrm{E}-02$ & $2.56 \mathrm{E}-03$ & $6.15 \mathrm{E}-03$ & $1.45 \mathrm{E}-03$ & $5.74 \mathrm{E}-03$ & $1.35 \mathrm{E}-03$ \\
\hline Cs-134 & $2.25 \mathrm{E}-03$ & $3.56 \mathrm{E}-03$ & $2.22 \mathrm{E}-03$ & $3.53 \mathrm{E}-03$ & $1.37 \mathrm{E}-03$ & $2.17 \mathrm{E}-03$ & $1.22 \mathrm{E}-03$ & $1.93 \mathrm{E}-03$ \\
\hline $\mathrm{Sr}-90$ & $3.81 \mathrm{E}-03$ & $1.01 \mathrm{E}-02$ & $1.99 \mathrm{E}-04$ & 5.26E-04 & $5.15 \mathrm{E}-04$ & $1.36 \mathrm{E}-03$ & $2.02 \mathrm{E}-05$ & $5.34 \mathrm{E}-05$ \\
\hline Ag-110m & $6.28 \mathrm{E}-02$ & $1.42 \mathrm{E}-02$ & $1.69 \mathrm{E}-02$ & $3.82 \mathrm{E}-03$ & $6.01 \mathrm{E}-03$ & $1.36 \mathrm{E}-03$ & $3.73 \mathrm{E}-04$ & 8.44E-05 \\
\hline Ag-111 & $2.27 \mathrm{E}-01$ & $2.04 \mathrm{E}-01$ & $6.16 \mathrm{E}-03$ & $5.51 \mathrm{E}-03$ & $1.73 \mathrm{E}-02$ & $1.55 \mathrm{E}-02$ & $9.46 \mathrm{E}-05$ & $8.45 \mathrm{E}-05$ \\
\hline $\mathrm{Sb}-125$ & $1.63 \mathrm{E}-06$ & $2.45 \mathrm{E}-07$ & $1.71 \mathrm{E}-06$ & $2.57 \mathrm{E}-07$ & $9.57 \mathrm{E}-08$ & $1.44 \mathrm{E}-08$ & $4.80 \mathrm{E}-09$ & 7.22E-10 \\
\hline Ru-103 & $1.27 \mathrm{E}-08$ & $9.44 \mathrm{E}-08$ & $1.97 \mathrm{E}-09$ & $1.47 \mathrm{E}-08$ & $1.16 \mathrm{E}-09$ & 8.69E-09 & $8.80 \mathrm{E}-11$ & $6.56 \mathrm{E}-10$ \\
\hline Ce-144 & 7.33E-05 & $3.18 \mathrm{E}-06$ & $9.30 \mathrm{E}-07$ & 4.03E-08 & 4.97E-06 & $2.15 \mathrm{E}-07$ & 4.49E-09 & $1.94 \mathrm{E}-10$ \\
\hline La-140 & $1.47 \mathrm{E}-07$ & $4.06 \mathrm{E}-08$ & $9.44 \mathrm{E}-10$ & $2.60 \mathrm{E}-10$ & $1.36 \mathrm{E}-08$ & $3.75 \mathrm{E}-09$ & $3.84 \mathrm{E}-11$ & $1.05 \mathrm{E}-11$ \\
\hline Pu-239 & $5.16 \mathrm{E}-10$ & $2.19 \mathrm{E}-11$ & $6.78 \mathrm{E}-11$ & $2.88 \mathrm{E}-12$ & $1.37 \mathrm{E}-12$ & $5.83 \mathrm{E}-14$ & 7.35E-18 & $3.12 \mathrm{E}-19$ \\
\hline Sum & $3.22 \mathrm{E}-01$ & 3.06E-01 & $3.06 \mathrm{E}-01$ & $1.43 E+00$ & $3.22 \mathrm{E}-02$ & $2.63 \mathrm{E}-02$ & $3.48 \mathrm{E}-02$ & $1.49 \mathrm{E}-01$ \\
\hline TOTAL & \multicolumn{2}{|c|}{$6.28 \mathrm{E}-01$} & \multicolumn{2}{|c|}{$1.74 E+00$} & \multicolumn{2}{|c|}{$5.84 \mathrm{E}-02$} & \multicolumn{2}{|c|}{$1.84 \mathrm{E}-01$} \\
\hline Limits (rem) & \multicolumn{2}{|c|}{0.5} & \multicolumn{2}{|c|}{1.5} & \multicolumn{2}{|c|}{0.5} & \multicolumn{2}{|c|}{1.5} \\
\hline
\end{tabular}


Table C-29. $250 \mathrm{MW}(\mathrm{t})$ pebble bed $700^{\circ} \mathrm{C}$ ROT — water ingress - Cases E and F, infant and adult $-800 \mathrm{~m}$ from release (rem).

\begin{tabular}{|c|c|c|c|c|c|c|c|c|}
\hline \multirow[t]{2}{*}{ Nuclide } & \multicolumn{2}{|c|}{$\begin{array}{l}\text { CASE E/Ingestion - milk/ } \\
\text { EDE (infant) }\end{array}$} & \multicolumn{2}{|c|}{$\begin{array}{l}\text { CASE F/Ingestion - milk/ } \\
\text { Thyroid (infant) }\end{array}$} & \multicolumn{2}{|c|}{$\begin{array}{l}\text { CASE E/Ingestion - milk/ } \\
\text { EDE (adult) }\end{array}$} & \multicolumn{2}{|c|}{$\begin{array}{l}\text { CASE F/Ingestion - milk/ } \\
\text { Thyroid (adult) }\end{array}$} \\
\hline & Short & Long & Short & Long & Short & Long & Short & Long \\
\hline Xe-133 & - & - & - & - & - & - & - & - \\
\hline $\mathrm{Kr}-85$ & - & - & - & - & - & - & - & - \\
\hline $\mathrm{Kr}-88$ & - & - & - & - & - & - & - & - \\
\hline I-131 & 4.63E-03 & $2.62 \mathrm{E}-02$ & $9.21 \mathrm{E}-02$ & $5.21 \mathrm{E}-01$ & $2.87 \mathrm{E}-04$ & $1.63 \mathrm{E}-03$ & $9.48 \mathrm{E}-03$ & $5.38 \mathrm{E}-02$ \\
\hline I-133 & $3.57 \mathrm{E}-04$ & $3.27 \mathrm{E}-04$ & $6.95 \mathrm{E}-03$ & $6.37 \mathrm{E}-03$ & $1.60 \mathrm{E}-05$ & $1.47 \mathrm{E}-05$ & $5.22 \mathrm{E}-04$ & $4.79 \mathrm{E}-04$ \\
\hline Te-132 & $1.73 \mathrm{E}-05$ & $6.88 \mathrm{E}-05$ & $2.34 \mathrm{E}-04$ & $9.33 \mathrm{E}-04$ & $7.20 \mathrm{E}-07$ & $2.87 \mathrm{E}-06$ & $1.68 \mathrm{E}-05$ & $6.73 \mathrm{E}-05$ \\
\hline Cs-137 & $4.45 \mathrm{E}-03$ & $1.06 \mathrm{E}-03$ & $3.98 \mathrm{E}-03$ & $9.51 \mathrm{E}-04$ & $2.26 \mathrm{E}-03$ & $5.38 \mathrm{E}-04$ & $2.11 \mathrm{E}-03$ & $5.03 \mathrm{E}-04$ \\
\hline Cs-134 & $8.26 \mathrm{E}-04$ & $1.33 \mathrm{E}-03$ & $8.15 \mathrm{E}-04$ & $1.31 \mathrm{E}-03$ & $5.03 \mathrm{E}-04$ & 8.07E-04 & 4.47E-04 & 7.19E-04 \\
\hline Sr-90 & $1.40 \mathrm{E}-03$ & $3.75 \mathrm{E}-03$ & $7.28 \mathrm{E}-05$ & $1.95 \mathrm{E}-04$ & $1.89 \mathrm{E}-04$ & $5.05 \mathrm{E}-04$ & $7.40 \mathrm{E}-06$ & $1.98 \mathrm{E}-05$ \\
\hline $\mathrm{Ag}-110 \mathrm{~m}$ & $2.30 \mathrm{E}-02$ & $5.27 \mathrm{E}-03$ & $6.18 \mathrm{E}-03$ & $1.42 \mathrm{E}-03$ & $2.21 \mathrm{E}-03$ & $5.07 \mathrm{E}-04$ & $1.37 \mathrm{E}-04$ & $3.15 \mathrm{E}-05$ \\
\hline Ag-111 & $8.37 \mathrm{E}-02$ & $7.60 \mathrm{E}-02$ & $2.26 \mathrm{E}-03$ & $2.05 \mathrm{E}-03$ & $6.36 \mathrm{E}-03$ & $5.79 \mathrm{E}-03$ & $3.47 \mathrm{E}-05$ & $3.15 \mathrm{E}-05$ \\
\hline Sb-125 & $5.97 \mathrm{E}-07$ & $9.07 \mathrm{E}-08$ & $6.24 \mathrm{E}-07$ & $9.48 \mathrm{E}-08$ & $3.49 \mathrm{E}-08$ & 5.32E-09 & $1.76 \mathrm{E}-09$ & $2.67 \mathrm{E}-10$ \\
\hline $\mathrm{Ru}-103$ & 4.65E-09 & $3.52 \mathrm{E}-08$ & 7.24E-10 & $5.47 \mathrm{E}-09$ & $4.28 \mathrm{E}-10$ & $3.23 \mathrm{E}-09$ & $3.24 \mathrm{E}-11$ & $2.45 \mathrm{E}-10$ \\
\hline Ce-144 & $2.69 \mathrm{E}-05$ & $1.18 \mathrm{E}-06$ & $3.40 \mathrm{E}-07$ & $1.50 \mathrm{E}-08$ & $1.82 \mathrm{E}-06$ & 8.01E-08 & $1.65 \mathrm{E}-09$ & $7.22 \mathrm{E}-11$ \\
\hline La-140 & $5.41 \mathrm{E}-08$ & $1.51 \mathrm{E}-08$ & $3.46 \mathrm{E}-10$ & $9.67 \mathrm{E}-11$ & $5.02 \mathrm{E}-09$ & $1.40 \mathrm{E}-09$ & $1.40 \mathrm{E}-11$ & $3.94 \mathrm{E}-12$ \\
\hline $\mathrm{Pu}-239$ & $1.89 \mathrm{E}-10$ & $8.16 \mathrm{E}-12$ & $2.48 \mathrm{E}-11$ & $1.07 \mathrm{E}-12$ & $5.02 \mathrm{E}-13$ & $2.16 \mathrm{E}-14$ & $2.69 \mathrm{E}-18$ & $1.16 \mathrm{E}-19$ \\
\hline Sum & $1.18 \mathrm{E}-01$ & $1.14 \mathrm{E}-01$ & $1.13 \mathrm{E}-01$ & $5.34 \mathrm{E}-01$ & $1.18 \mathrm{E}-02$ & $9.79 \mathrm{E}-03$ & $1.28 \mathrm{E}-02$ & $5.56 \mathrm{E}-02$ \\
\hline TOTAL & \multicolumn{2}{|c|}{ 2.32E-01 } & \multicolumn{2}{|c|}{$6.47 \mathrm{E}-01$} & \multicolumn{2}{|c|}{ 2.16E-02 } & \multicolumn{2}{|c|}{$6.84 \mathrm{E}-02$} \\
\hline Limits (rem) & \multicolumn{2}{|c|}{0.5} & \multicolumn{2}{|c|}{1.5} & \multicolumn{2}{|c|}{0.5} & \multicolumn{2}{|c|}{1.5} \\
\hline
\end{tabular}


Table C-30. $250 \mathrm{MW}(\mathrm{t})$ pebble bed $700^{\circ} \mathrm{C}$ ROT - water ingress-Cases E and F, infant and adult- $1600 \mathrm{~m}$ from release (rem).

\begin{tabular}{|c|c|c|c|c|c|c|c|c|}
\hline \multirow[t]{2}{*}{ Nuclide } & \multicolumn{2}{|c|}{$\begin{array}{c}\text { CASE E/Ingestion - milk/ } \\
\text { EDE (infant) }\end{array}$} & \multicolumn{2}{|c|}{$\begin{array}{c}\text { CASE F/Ingestion - milk/ } \\
\text { Thyroid (infant) }\end{array}$} & \multicolumn{2}{|c|}{$\begin{array}{l}\text { CASE E/Ingestion - milk/ } \\
\text { EDE (adult) }\end{array}$} & \multicolumn{2}{|c|}{$\begin{array}{c}\text { CASE F/Ingestion - milk/ } \\
\text { Thyroid (adult) }\end{array}$} \\
\hline & Short & Long & Short & Long & Short & Long & Short & Long \\
\hline Xe-133 & - & - & - & - & - & - & - & - \\
\hline $\mathrm{Kr}-85$ & - & - & - & - & - & - & - & - \\
\hline $\mathrm{Kr}-88$ & - & - & - & - & - & - & - & - \\
\hline I-131 & $1.69 \mathrm{E}-03$ & $9.88 \mathrm{E}-03$ & $3.35 \mathrm{E}-02$ & $1.97 \mathrm{E}-01$ & $1.05 \mathrm{E}-04$ & $6.16 \mathrm{E}-04$ & $3.46 \mathrm{E}-03$ & $2.03 \mathrm{E}-02$ \\
\hline I-133 & $1.29 \mathrm{E}-04$ & $1.22 \mathrm{E}-04$ & $2.51 \mathrm{E}-03$ & $2.40 \mathrm{E}-03$ & $5.82 \mathrm{E}-06$ & $5.54 \mathrm{E}-06$ & $1.89 \mathrm{E}-04$ & $1.80 \mathrm{E}-04$ \\
\hline Te-132 & $6.29 \mathrm{E}-06$ & $2.60 \mathrm{E}-05$ & $8.56 \mathrm{E}-05$ & $3.51 \mathrm{E}-04$ & $2.62 \mathrm{E}-07$ & $1.08 \mathrm{E}-06$ & $6.14 \mathrm{E}-06$ & $2.54 \mathrm{E}-05$ \\
\hline Cs-137 & $1.62 \mathrm{E}-03$ & $4.02 \mathrm{E}-04$ & $1.45 \mathrm{E}-03$ & $3.59 \mathrm{E}-04$ & $8.25 \mathrm{E}-04$ & $2.04 \mathrm{E}-04$ & 7.69E-04 & $1.90 \mathrm{E}-04$ \\
\hline Cs-134 & $3.00 \mathrm{E}-04$ & $5.01 \mathrm{E}-04$ & $2.98 \mathrm{E}-04$ & $4.95 \mathrm{E}-04$ & $1.83 \mathrm{E}-04$ & $3.05 \mathrm{E}-04$ & $1.63 \mathrm{E}-04$ & $2.72 \mathrm{E}-04$ \\
\hline Sr-90 & $5.11 \mathrm{E}-04$ & $1.41 \mathrm{E}-03$ & $2.66 \mathrm{E}-05$ & 7.37E-05 & $6.87 \mathrm{E}-05$ & $1.90 \mathrm{E}-04$ & $2.70 \mathrm{E}-06$ & $7.47 \mathrm{E}-06$ \\
\hline $\mathrm{Ag}-110 \mathrm{~m}$ & $8.36 \mathrm{E}-03$ & $1.98 \mathrm{E}-03$ & $2.25 \mathrm{E}-03$ & $5.35 \mathrm{E}-04$ & $8.06 \mathrm{E}-04$ & $1.91 \mathrm{E}-04$ & $4.99 \mathrm{E}-05$ & $1.19 \mathrm{E}-05$ \\
\hline Ag-111 & $3.05 \mathrm{E}-02$ & $2.87 \mathrm{E}-02$ & $8.24 \mathrm{E}-04$ & 7.77E-04 & $2.32 \mathrm{E}-03$ & $2.18 \mathrm{E}-03$ & $1.27 \mathrm{E}-05$ & $1.19 \mathrm{E}-05$ \\
\hline $\mathrm{Sb}-125$ & $2.17 \mathrm{E}-07$ & $3.42 \mathrm{E}-08$ & $2.27 \mathrm{E}-07$ & $3.54 \mathrm{E}-08$ & $1.27 \mathrm{E}-08$ & $1.99 \mathrm{E}-09$ & $6.40 \mathrm{E}-10$ & $1.00 \mathrm{E}-10$ \\
\hline Ru-103 & $1.70 \mathrm{E}-09$ & $1.33 \mathrm{E}-08$ & $2.65 \mathrm{E}-10$ & 2.07E-09 & $1.56 \mathrm{E}-10$ & $1.22 \mathrm{E}-09$ & $1.19 \mathrm{E}-11$ & $9.21 \mathrm{E}-11$ \\
\hline $\mathrm{Ce}-144$ & $9.80 \mathrm{E}-06$ & $4.44 \mathrm{E}-07$ & $1.24 \mathrm{E}-07$ & $5.65 \mathrm{E}-09$ & $6.64 \mathrm{E}-07$ & $3.02 \mathrm{E}-08$ & $6.00 \mathrm{E}-10$ & $2.72 \mathrm{E}-11$ \\
\hline La-140 & $1.97 \mathrm{E}-08$ & $5.67 \mathrm{E}-09$ & $1.26 \mathrm{E}-10$ & $3.65 \mathrm{E}-11$ & $1.82 \mathrm{E}-09$ & $5.26 \mathrm{E}-10$ & $5.12 \mathrm{E}-12$ & $1.48 \mathrm{E}-12$ \\
\hline Pu-239 & $6.89 \mathrm{E}-11$ & $3.06 \mathrm{E}-12$ & $9.05 \mathrm{E}-12$ & $4.02 \mathrm{E}-13$ & $1.83 \mathrm{E}-13$ & $8.14 \mathrm{E}-15$ & $9.78 \mathrm{E}-19$ & $4.36 \mathrm{E}-20$ \\
\hline Sum & $4.31 \mathrm{E}-02$ & $4.30 \mathrm{E}-02$ & $4.10 \mathrm{E}-02$ & 2.02E-01 & $4.32 \mathrm{E}-03$ & $3.70 \mathrm{E}-03$ & $4.66 \mathrm{E}-03$ & $2.10 \mathrm{E}-02$ \\
\hline TOTAL & \multicolumn{2}{|c|}{ 8.62E-02 } & \multicolumn{2}{|c|}{$2.43 E-01$} & \multicolumn{2}{|c|}{ 8.01E-03 } & \multicolumn{2}{|c|}{$2.57 \mathrm{E}-02$} \\
\hline Limits (rem) & \multicolumn{2}{|c|}{0.5} & \multicolumn{2}{|c|}{1.5} & \multicolumn{2}{|c|}{0.5} & \multicolumn{2}{|c|}{1.5} \\
\hline
\end{tabular}


Appendix D

\section{Key Limitations and Assumptions Used in the Scoping Analyses}




\section{Appendix D \\ Key Limitations and Assumptions Used in the Scoping Analyses}

1. The results of these analyses are not intended for, nor are they suitable for, submittal to regulatory authorities as part of the licensing basis the high temperature gas-cooled reactor (HTGR). The analyses are intended solely to provide insights and internal guidance for the Next Generation Nuclear Plant (NGNP) Project.

2. In the absence of certain technical information to support a detailed mechanistic assessment, the NGNP Project utilized a simplified model to perform parametric scoping analyses of the release and retention parameters that define the source terms for a modular HTGR.

3. The results are based on accident scenarios for a single HTGR module. Additional analyses will be needed to confirm that project objectives are satisfied for multi-module HTGR facilities for postulated events that may result in fission product releases from more than one module.

4. Based on safety analyses performed for prior gas-cooled reactor studies, breaks in the helium pressure boundary (HPB) and water ingress events were assumed to pose the greatest challenges with respect to offsite dose consequences.

5. Barrier performance

- Barrier performance was estimated based on expert opinion. As more testing is completed under the NGNP Technology Development Program and further design development is completed, the assumed values for the barrier performance allocations can be revised, as necessary, and detailed accident analyses can be performed.

- Radionuclide retention of the barriers associated with fuel and graphite was estimated based on current capabilities of the technology as recently demonstrated in the Advanced Gas Reactor fuel program.

- Radionuclide retention of the HPB and reactor building under accident conditions were intentionally estimated on a conservative basis to account for uncertainty in the underlying phenomenology and so as not to constrain the development of design.

- In assessing against the NRC siting criteria, the analyses utilized conservative estimates regarding the performance of the radionuclide release barriers, and did not credit any fission product release attenuation by the reactor building.

- In assessing against the Environmental Protection Agency plume exposure Protective Action Guides (PAGs), the analyses utilized realistic (mean) estimates on the performance of the radionuclide barriers including the reactor building.

6. All radionuclides within a fission product class in the source term are assumed to have the same release and attenuation factors based on physical and chemical properties.

7. Each fission product group in the source term contains the key radionuclides identified via past modular HTGR analyses that are expected to account for the majority of the offsite dose.

8. To account for uncertainty in fuel and barrier performance, the review team assigned $50 \%$ and $95 \%$ confidence values to the defect fractions and attenuation factors upon which the mechanistic source terms are based. Fuel defect fraction uncertainties were assumed to be normally distributed. Attenuation factor uncertainties were assumed to be lognormally distributed. 
9. Individual radionuclide inventories used in the evaluation were based on the $600 \mathrm{MW}(\mathrm{t})$ prismatic configuration. Radionuclide inventories for the $250 \mathrm{MW}(\mathrm{t})$ pebble bed configuration were scaled based on that inventory. It is recognized that the scaling approach is an approximation that does not take into account the detailed differences between the pebble and prismatic fuel configurations and the detailed differences between the operating conditions of the two reactors.

10. Time dependent radionuclide releases were grouped into two steps: an early and delayed release.

11. Atmospheric conditions (X/Q) assumed for the PAG analyses were based on mean conditions, consistent with regulatory guidance. Less probable, more stable (i.e., higher $X / \mathrm{Q}$ ) atmospheric conditions would cause all of the dose results to increase. 